
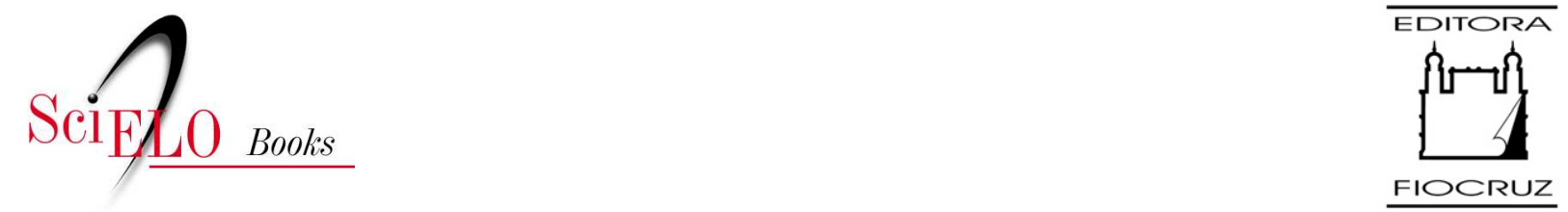

\title{
Caminhos da saúde pública no Brasil
}

\author{
Jacobo Finkelman
}

(Org.)

FINKELMAN, J., org. Caminhos da saúde no Brasil [online]. Rio de Janeiro: Editora FIOCRUZ, 2002. 328 p. ISBN 85-7541-017-2. Available from SciELO Books <http://books.scielo.org>.

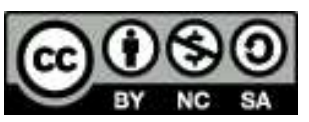

All the contents of this chapter, except where otherwise noted, is licensed under a Creative Commons Attribution-Non Commercial-ShareAlike 3.0 Unported.

Todo o conteúdo deste capítulo, exceto quando houver ressalva, é publicado sob a licença Creative Commons Atribuição - Uso Não Comercial - Partilha nos Mesmos Termos 3.0 Não adaptada.

Todo el contenido de este capítulo, excepto donde se indique lo contrario, está bajo licencia de la licencia Creative Commons Reconocimento-NoComercial-CompartirIgual 3.0 Unported. 
Jacobo Finkelman Organizador

\section{C Gaminhos}

da Saúde Pública no Brasil
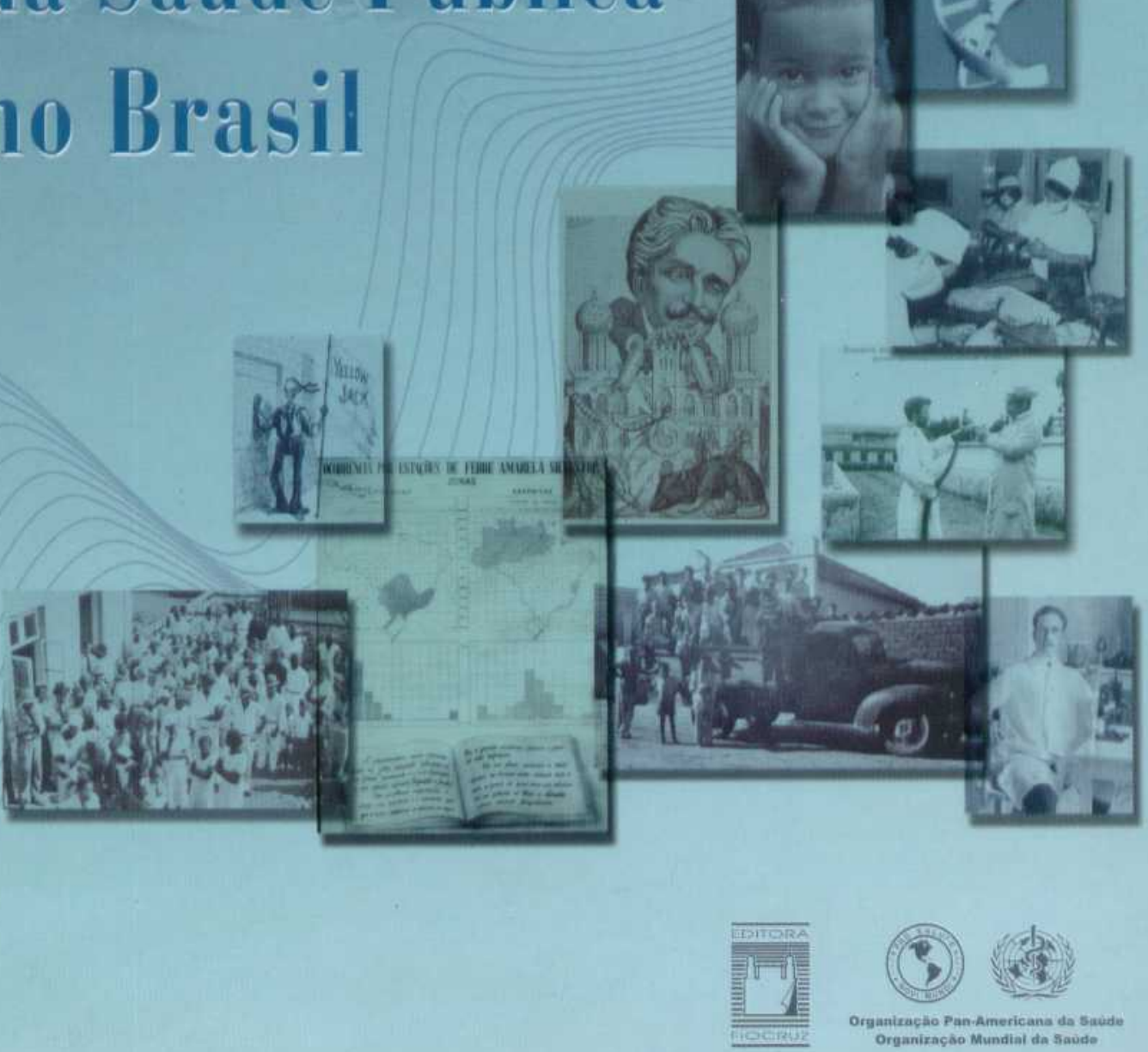
É com emoção e alegria que introduzo os leitores a este belo documento que registra as relações da Organização PanAmericana de Saúde (OPAS) com nosso país nos últimos cem anos.

Criada em 1902, contemporânea, portanto, à Fundação Oswaldo Cruz, a OPAs tem sua trajetória profundamente vinculada às vicissitudes, erros, acertos, esperanças e, também, aos fracassos e problemas dos sistemas de saúde do continente americano.

É importante salientar que a documentação que nos traz Caminbos da Saúde Pública no Brasil mostra que a contribuição da OPAS com o país e deste com a Organização foi algo que modernamente se denomina "um caso de sucesso".

Nísia Trindade Lima, João Baptista Risi Junior, Roberto Passos Nogueira e Otávio Azevedo Mercadante lideram os grupos que prepararam os textos sobre a trama de parcerias, mútuo respeito $\mathrm{e}$ cooperação que caracterizaram durante este século de existência o Brasil e a OPAS; sobre a evolução das condições de saúde do país ao longo deste tempo e sobre a evolução do nosso sistema público de saúde. Não são apenas autores analisando uma história, mas protagonistas desta mesma história em tempos, posições e funções diversas.

Os textos que abrem este livro, de Sir George Alleyne, diretor da OPAS, e Jacobo Finkelman, representante da Organização 
Caminhos

da Saúde Pública

no Brasil 
FUNDAÇÃO OSWALDO CRUZ

Presidente

Paulo Marchiori Buss

Vice-Presidente de Desenvolvimento Institucional, Informação e

Comunicação

Paulo Gadelba

EDITORA FIOCRUZ

Coordenador

Paulo Gadelba

Conselho Editorial

Carlos E. A. CoimbraJr.

Carolina M. Bori

Cbarles Pessanba

Jaime L. Bencbimol

José da Rocba Carvalbeiro

José Rodrigues Coura

Luis David Castiel

Luiz Fernando Ferreira

Maria Cecllia de Souza Minayo

Miriam Strucbiner

Paulo Amarante

Vanize Macêdo

Coordenador Executivo

João Carlos Canossa P. Mendes
ORGANIZAÇÃO PAN-AMERICANA DA SAÚDE

Comitê Editorial do Centenário

Presidente

Jacobo Finkelman

Comitê Editorial

Carlos Wilson de Andrade Filbo

José Carvalbo de Noronba

Maria Regina Fernandes de Oliveira

Mário Scheffer

Milton Tbiago de Melo

Nísia Trindade Lima

Paulo Henrique de Souza

René Dubois 
Jacobo Finkelman

()rganizador

Caminhos

da Saúde Pública

no Brasil

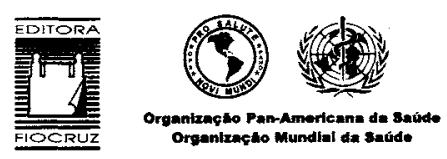


Copyright (C) 2002 dos autores

Todos os direitos desta edição reservados à

FUNDAÇÃO OSWALDO CRUZ/EDITORA E ORGANIZAÇÃO

PAN-AMERICANA DA SAÚDE/ORGANIZAÇÃO MUNDIAL DA SAÚDE

ISBN: $85-7541-017-2$

Capa, Projeto Gráfico: Carlota Rios e Gordeeff Editoração Eletrônica: Ramon Carlos de Moraes

Revisão: Fernanda Veneu, Fani Knoploch e Janaina de Souza Silva

Supervisão Editorial: Maria Cecilia G. B. Moreira

Catalogação-na-fonte

Centro de Informação Científica e Tecnológica

Biblioteca Lincoln de Freitas Filho

F499c Finkelman, Jacobo (Org.)

Caminhos da saúde pública no Brasil. / Organizado por Jacobo Finkelman. Rio de Janeiro: Editora Frocruz, 2002.

328p. ilus., tab., graf., mapas

1. Política de saúde-Brasil. 2. Organização Pan-Americana da Saúdehistória. 3. Sistema de saúde-Brasil. I. Título.

$\operatorname{CDD}$ - 20.ed. -362.1

2002

Editora Fiocruz

Av. Brasil, 4036 - $1^{\circ}$ andar - sala 112 - Manguinhos

21040-361 - Rio de Janeiro - RJ

Tels.: (21) 3882-9039 e 3882-9041

Telefax: (21) 3882-9006

http://www.fiocruz.br/editora

e-mail: editora@fiocruz.br 


\section{Autores e Colaboradores}

\section{Jacobo Finkelman (Organizador)}

Médico, mestre em saúde pública e administração em saúde, representante da Organização PanAmericana da Saúde (OpAs) no Brasil jacobof@bra.ops-oms.org

\section{Capítulo 1}

\section{Nísia Trindade Lima}

Cientista social, doutora em sociologia, pesquisadora e diretora da Casa de Oswaldo Cruz da Fundação Oswaldo Cruz (COC/Frockuz) e professora de sociologia da Universidade do Estado do Rio de Janeiro (URRI) lima@coc.fiocruz.br

\section{Contribuições}

\section{Abel Laerte Parker}

Administrador, mestre em biblioteconomia e ciência, diretor do Centro Latino-Americano e do Caribe de Informação em Ciências da Saúde (BiremE/OPAs)

abel@bireme.br

\section{Eduardo Correa Melo}

Médico veterinário, mestre em administração e em planificação em saúde animal, diretor do Centro Pan-Americano de Febre Aftosa (Panafros/OPas)

ecorrea@panaftosa.ops-oms.org 


\section{Capítulo 2}

\section{João Baptista Risi Junior (Coordenador)}

Médico, com especialização em vigilância epidemiológica, coordenador do Projeto de Informação em Saúde da OPAS

risi@bra.ops-oms.org

\section{Roberto Passos Nogueira (Coordenador)}

Médico, doutor em saúde coletiva, pesquisador do Instituto de Pesquisa Econômica Aplicada (IPEA) e do Núcleo de Estudos em Saúde Pública da Universidade de Brasilia (Nesp/UnB) nogueira@ipea.gov.br

\section{Colaboradores}

\section{Adelemara Mattoso Allonzi}

Estatística, técnica da Divisão de Epidemiologia e Vigilância do Instituto Nacional de Câncer (INca) do Ministério da Saúde

amoraes@inca.org.br

\section{André Monteiro Alves Pontes}

Engenheiro de minas e de saúde pública, mestre em saúde pública, assistente de pesquisa do Centro de Pesquisas Aggeu Magalhães (CPqAM) da FrockIz

andremc@cpqam.fiocruz.br

\section{Antonio Carlos Silveira}

Médico, com especialização em saúde pública, consultor temporário da OPAS atcrs@uol.com.br

\section{Carlos Antonio Pontes}

Engenheiro civil, mestre em engenharia sanitária, pesquisador visitante do CPqAM/FrocRUZ cpontes@cpqam.fiocruz.br

\section{Celso Cardoso Simões}

Demógrafo, doutor em demografia, pesquisador do Instituto Brasileiro de Geografia e Estatítica (IBGE)

ccss@ibge.gov.br

\section{Eduardo Hage Carmo}

Médico, doutor em epidemiologia, coordenador geral de Vigilância Epidemiológica do Centro Nacional de Epidemiologia (CENEPI) da Fundação Nacional de Saúde (FunasA) do Ministério da Saúde

eduardo.carmo@funasa.gov.br

\section{Fernando Ribeiro de Barros}

Médico, mestre em saúde pública, coordenador de Vigilância de Doenças de Transmissão Respiratória do CEnep//Funasa/Ministério da Saúde fernando.barros@funasa.gov.br 


\section{Germano Gerbardt Filho}

Médico, com especialização em pneumologia, professor adjunto da Faculdade de Medicina da Universidade Federal do Rio de Janeiro (UFRJ)

ggerhardtf@uol.com.br

\section{Gerson Fernando Mendes Pereira}

Médico, mestre em epidemiologia, coordenador nacional da área técnica de Dermatologia Sanitária do Ministério da Saúde

gerson.fernando@saude.gov.br

\section{Ines Lessa}

Médica, doutora em medicina, professora da Pós-Graduação do Instituto de Saúde Coletiva (ISC) da Universidade Federal da Bahia (UrBA)

ines@ufba.br

\section{Jarbas Barbosa da Silva Junior}

Médico, mestre em saúde pública, diretor do CENEPI/FunasA/Ministério da Saúde

jarbas.barbosa@funasa.gov.br

\section{Laércio Joel Franco}

Médico, livre-docente em medicina preventiva, professor titular da Faculdade de Medicina de Ribeirão Preto da Universidade de São Paulo (USP)

lfranco@fmrp.usp.br

\section{Marceli de Oliveira Santos}

Estatística, mestre em saúde pública, técnica da Divisão de Epidemiologia e Vigilância do INCN Ministério da Saúde msantos@inca.org.br

\section{Marcelo Medeiros}

Economista, mestre em sociologia, pesquisador do IPEA

medeiros@ipea.gov.br

\section{Marcia Regina Dias Alves}

Estatística, bacharel em ciências estatísticas, técnica da Divisão de Epidemiologia e Vigilância do INCA/Ministério da Saúde malves@inca.gov.br

\section{Maria Cecilia de Souza Minayo}

Socióloga, doutora em saúde pública, pesquisadora titular da FoocrLz, coordenadora científica do Centro Latino-Americano de Estudos sobre Violência e Saúde (Cuvves/Frockuz) e representante regional do Fórum Mundial de Ciências Sociais e Saúde cecilia@claves.fiocruz.br

\section{Maria Goretti P. Fonseca}

Médica, doutora em saúde pública, epidemiologista da Funasa/Ministério da Saúde goretti@aids.gov.br 


\section{Maria Helena P. de Mello Jorge}

Advogada, doutora e livre-docente em saúde pública, professora associada da Faculdade de Saúde Pública (FSP) da USP

mhpjorge@usp.br

\section{Maurício Barreto}

Médico, doutor em epidemiologia, professor titular do ISC/JrBA

mauricio@ufba.br

\section{Mauro da Rosa Elkboury}

Médico veterinário, com especialização em saúde pública e epidemiologia, gerente técnico do Programa de Controle da Raiva do Cenep/Funas/Ministério da Saúde mauro.elkhoury@funasa.gov.br

\section{Ruy Laurenti}

Médico, doutor em medicina e livre-docente em epidemiologia, professor titular da FSP/USP laurenti@usp.br

\section{Sabina Léa Davidson Gotlieb}

Odontóloga, doutora e livre-docente em saúde pública, professora associada da FSP/USP sgotlieb@usp.br

\section{Valeska Carvalbo Figueiredo}

Médica, mestre em saúde pública, gerente da Divisão de Epidemiologia e Vigilância do INca/Ministério da Saúde

valeska@inca.org.br

\section{Zuleica Portela Albuquerque}

Médica, mestre em nutrição humana, profissional nacional do Projeto de Promoção de Saúde da OPAs

zuleica@bra.ops-oms.org

\section{CÁі́tclo 3}

\section{Otávio Azevedo Mercadante (Coordenador)}

Médico, mestre em saúde pública, professor associado da Faculdade de Ciências Médicas da Santa Casa de São Paulo (FCM/Sta.Casa SP) e secretário executivo do Ministério da Saúde otavio@saude.gov.br

\section{Colaboradores}

\section{Alfredo Schechtman}

Médico, mestre em saúde coletiva, assessor da área técnica de Saúde Mental do Ministério da Saúde

alfredo.schechtmann@saude.gov.br 


\section{Bianca Antunes Cortes}

Enfermeira, doutora em engenharia de produção, pesquisadora associada do Departamento de Pesquisa da COC/FIocriz

bcortes@coc.fiocruz.br

\section{Ermenegyldo Munboz Junior}

Arquiteto e urbanista, com especialização em demografia e planejamento, assessor do secretário-executivo do Ministério da Saúde

gyl.munhoz@saude.gov.br

\section{Eugênio Vilaça Mendes}

Odontólogo, doutor em odontologia, consultor independente em desenvolvimento de saúde eugenio.bhz@terra.com.br

\section{Julio Alberto Wong Un}

Médico, doutor em saúde pública, supervisor do Programa de Controle do Câncer e seus Fatores de Risco do INCAMinistério da Saúde

jwong@inca.gov.br

\section{Marcelo Medeiros}

\section{Maria do Socorro A. Lemos}

Médica, com especialização em epidemiologia e infectologia, consultora técnica do Projeto de Promoção de Saúde da OPAS

msocorro.lemos@saude.gov.br

\section{Miguel Malo Serrano}

Médico, mestre em saúde internacional, coordenador do Projeto de Promoção de Saúde da OPAS miguel@bra.ops-oms.org

\section{Ricardo Henrique Sampaio Meirelles}

Médico, com especialização em pneumologia, sub-chefe da Divisão de Controle do Tabagismo e outros Fatores de Risco de Câncer do IncaMinistério da Saúde

ricardohm@inca.gov.br

\section{Roberto Passos Nogueira}

\section{Sérgio Piola}

Médico, com especialização em saúde pública, pesquisador do IPra

piola@ipea.gov.br

\section{Solon Magalbães Vianna}

Odontólogo, livre-docente em saúde pública, consultor do IPEA e membro do Conselho Nacional de Saúde

solon@yawl.com.br

\section{Valeska Carvalbo Figueiredo}




\section{IMAGENS}

\section{Pesquisa}

Nísia Trindade Lima (Coordenadora)

\section{Cristiane Batista}

Cientista social, mestre em ciência política, assistente de pesquisa da COC/Flocruz cris.santos@openlink.com.br

Fotografias e reprodução das imagens

\section{Roberto Jesus Oscar}

Fotógrafo do Departamento de Arquivo e Documentação da COC/FiocRUz rob@coc.fiocruz.br

\section{Vinícius Pequeno de Souza}

Fotógrafo do Departamento de Arquivo e Documentação da COC/Frocruz pequeno@coc.fiocruz.br 


\section{SuMÁrI0}

Prefácio 13

Apresentação 17

1. 0 Brasil e a Organização Pan-Americana da Saúde:

uma história de trềs dimensões

23

Nisia Trindade Lima

2. As Condiçöes de Saúde no Brasil

117

João Baptista Risi Junior e Roberto Passos Nogueira Coordenadores

3. Evolução das Políticas e do Sistema de Saúde no Brasil

Otávio Azevedo Mercadante

Coordenador

Imagens $\quad 315$ 


\section{Prefácio}

É um prazer poder prefaciar Caminhos da Saúde Pública no Brasil, produzido como parte da celebração do Centenário da Organização PanAmericana da Saúde (OPAs) no Brasil. Devo felicitar os que conceberam o título do livro, pois ele transmite uma forte imagem do que foi o passado e do que o futuro pode ser. Muitos são os caminhos que, quando seguidos, conduzem à boa saúde, e o conceito de caminho também implica que há um começo, um estado atual e um espaço adiante. Há um caminho adiante a ser construído, o qual deverá ser melhor que o do passado, pois teremos a vantagem de conhecer as armadilhas e os perigos a serem evitados.

Essa imagem é apropriada para o conjunto da OpAs. Na verdade, quando a Organização foi fundada em 1902, seu foco de atenção era as doenças infecciosas, e o caminho era claramente direcionado à conquista dessas enfermidades, com as ferramentas e os programas então disponíveis. Hoje, reconhecemos que 0 espectro de doenças que os países têm de enfrentar é mais complexo, como também o caminho que têm a seguir. 0s países devem lidar com um verdadeiro mosaico de enfermidades e procurar 
as ferramentas apropriadas para abordar, simultaneamente, múltiplos problemas. Estou particularmente feliz de ver a importância dada à promoção da saúde, pois acredito que a aplicação astuciosa de estratégias pertinentes representa um meio eficaz para tratar os complexos problemas defrontados na luta para melhorar a saúde do povo brasileiro.

Durante os últimos cem anos, a OpAs seguiu diferentes caminhos em sua eterna busca por ser útil aos países da Região. Houve um tempo no qual a Organização foi reativa aos problemas de saúde dos países. Hoje o enfoque é muito mais proativo, nós cooperamos tecnicamente usando várias abordagens, apropriadas à situação de saúde dos países, individualmente. Não há dúvida, entretanto, que os caminhos que procuramos e trilhamos estão todos voltados para melhorar a saúde dos povos das Américas, na perspectiva de que essa saúde seja distribuída mais equiitativamente.

É importante que livros como este tenham um sabor histórico, não servindo apenas para que as gerações futuras possam reconhecer a luta daqueles que os precederam. É também importante observar os eventos históricos de saúde no contexto de outras circunstâncias sociais e apreciar as soluções que tiveram de ser buscadas. Com essa análise, podemos encontrar meios de evitar alguns perigos e avançar mais rapidamente nos caminhos para a melhor saúde. A história dos progressos realizados neste país é importante para as Américas e, possivelmente, para o mundo. Por seu tamanho, o Brasil apresenta vários tipos de microrregiões, o que, de certa forma, pode ser representativo de quase qualquer país no hemisfério.

Caminhos da Saúde Pública no Brasil assinala, com singeleza, as diferenças que existem entre as regiões do Brasil. Por conta dessa diversidade, organizou-se um sistema de informação capaz de demonstrar a natureza das diferenças e o tipo de sistema de saúde que certamente irá reduzir essas brechas. A coragem de estabelecer o sistema único de saúde e, ao mesmo tempo, de rumar para a verdadeira descentralização, é um aspecto histórico deste livro que chamará a atenção de muitos no exterior. Esta coragem e 
determinação de que todos os caminhos a serem seguidos conduzem à saúde são vistas em muitos outros lugares.

A Opas sente orgulho de estar associada à produção desta obra e estamos agradecidos aos diversos autores que detalharam a relação deste país com a nossa Organização. Orgulhamo-nos dessa relação e poderíamos acrescentar numerosos exemplos da participação positiva do Brasil na vida de nossa Organização.

Tenho insistido em que, neste ano do Centenário, nosso foco não deve estar primariamente dirigido ao que a $\mathrm{OPAS}_{\mathrm{P}}$ fez, mas sim ao que foi alcançado na saúde nas Américas, com a assistência da Organização. Caminbos da Saúde Pública no Brasil é um bom exemplo desse enfoque. Desejo que seja lido e apreciado por muitos, não apenas pelos detalhes que fornece sobre o que ocorreu na saúde no Brasil, mas também por revelar os homens e as mulheres que fizeram essa história à medida que trilharam os diversos caminhos condutores à melhoria da saúde.

George A. O. Alleyne Diretor da Organização Pan-Americana da Saúde 


\section{APRESENTAÇÃ̃}

Este livro, que é parte das comemorações do centenário da Organização Pan-Americana da Saúde (OpAs) no Brasil, surgiu da idéia de elaborar uma visão ampla daquilo que foi, no decorrer do século $\mathrm{XX}$, a evolução das políticas, os principais programas e o desenvolvimento dos serviços voltados para a melhoria da saúde dos brasileiros. Pensamos que um livro de tal natureza deveria ir além do relato histórico e contribuir, de algum modo, para entender melhor o processo gradual de consolidação da saúde, entendido como um direito do cidadão e um dever do Estado, tal como está expresso na Constituição brasileira de 1988.

Com esse propósito, um grupo seleto de autores foi convidado a contribuir com Caminhos da Saúde Pública no Brasil, relatando uma história muito rica sobre os desafios e as lutas que mudaram os perfis demográficos e epidemiológicos do país. Este livro tem o valor de reunir muitos aspectos históricos significativos, de analisar as tendências dos principais problemas e dos indicadores de saúde e de discutir os principais critérios adotados pela sociedade brasileira para organizar o seu sistema de saúde. 
Bastaria um exame superficial dos principais indicadores de saúde para reconhecer que, ao longo do período em estudo, o Brasil fez progressos significativos. A população total passou de aproximadamente 20 milhões de habitantes, em princípios do século XX, para mais de 170 milhões, cem anos depois. A mortalidade infantil, estimada para inícios do século $\mathrm{XX}$ em aproximadamente 190 por mil nascidos-vivos, é agora de 29,8 , como valor médio nacional. A mortalidade por enfermidades infecto-contagiosas passou de $45,7 \%$ do total de óbitos, em 1930, para 5,9\%, em 1999, e a expectativa de vida mais que duplicou no século $\mathrm{XX}$, passando de 33,7 anos, em 1900 , para 68,6 anos, em 2000.

Assim como o Brasil fez avanços importantes em matéria de saúde, também é evidente a persistência de inegáveis problemas estruturais, 'que determinam profundas desigualdades sociais, incluídas aí as de saúde. Embora a mortalidade infantil tenha sido drasticamente reduzida nos últimos decênios, as diferenças interregionais mostram hoje que, nos estados da região Sul, com melhores condições de vida, a taxa é de 19,7 por mil nascidos-vivos, contra 44,2 na região Nordeste, onde persistem maiores níveis de pobreza. Tal situação não é particular do Brasil, pois, em todos os países em desenvolvimento, constatam-se diversos graus de iniquiidade quanto ao acesso, à qualidade e aos resultados dos diferentes programas de saúde.

Caminbos da Saúde Pública no Brasil aborda como o país foi capaz de incorporar, na organização de seus programas de saúde, os elementos teórico-conceituais emergentes que sustentaram a evolução de seus paradigmas da saúde, considerando os diferentes momentos de seu desenvolvimento social, político e econômico. Mostra ainda como esses estágios de desenvolvimento, nacional e regional, influíram, por sua vez, na formulação e na transformação das políticas e programas de saúde, desde os estágios iniciais, dominados por um modelo de produção orientado à exportação de matérias-primas de origem agrícola, passando pela expansão urbano-industrial, até o momento atual, em que o Brasil luta por definir seu espaço como protagonista em um mundo de crescente globalização e interdependência. 
Esta publicação compõe-se de três capítulos. 0 primeiro, ' 0 Brasil e a Organização Pan-Americana da Saúde: uma história em três dimensões', escrito por Nísia Trindade Lima, analisa o desenvolvimento da saúde pública brasileira, a partir das teorias contagionistas em voga nos finais do século XIX e do início da escola bacteriológica emergente, e de que forma as doutrinas e os embates teóricos de então influíram no enorme esforço realizado para controlar as grandes endemias de febre amarela, peste e varíola que assolavam o continente americano. Neste capítulo também se descrevem as relações entre o Brasil e a Opas em diferentes momentos, nos quais ambos, o país e a Organização, tentavam ampliar as fronteiras da saúde, sobretudo durante a primeira metade do século XX. É dado especial destaque ao papel que cada uma das partes desempenhou nesta parceria e à convergência de interesses, da qual surgiram importantes programas regionais e várias iniciativas que permitiram ao país criar e desenvolver instituições que hoje atuam de forma destacada em prol da saúde nacional e internacional. Assim, o capítulo destaca a criação e o papel que vêm desempenhando dois centros pan-americanos sediados no Brasil, instituídos por acordos firmados entre a OPAS e o governo brasileiro: o Centro Pan-Americano de Febre Aftosa (Panaftosa), localizado em Duque de Caxias, no estado do Rio de Janeiro, criado em 1951, e a Biblioteca Regional de Medicina (BiremE), com sede na cidade de São Paulo, criada em 1967.

0 capítulo 2, 'As Condições de Saúde no Brasil', coordenado por João Baptista Risi Jr. e Roberto Passos Nogueira, apresenta resumidamente a evolução dos principais indicadores demográficos e epidemiológicos, assim como alguns dos determinantes básicos da saúde. São analisadas as tendências de algumas das doenças transmissíveis, entre elas, as que foram erradicadas, algumas que se encontram em fase de declínio, outras que apresentam uma situação epidemiológica estacionária e, finalmente, certas enfermidades emergentes. Discute-se também a crescente importância das doenças não transmissiveis e as novas prioridades em saúde, como os problemas derivados dos acidentes e da violência. Aborda-se ainda o tema das 
desigualdades e iniquiidades em saúde, observado a partir dos diferentes padrões epidemiológicos prevalentes no país.

O terceiro capítulo, 'Evolução das Políticas e do Sistema de Saúde no Brasil', coordenado pelo Secretário Executivo do Ministério da Saúde, Dr. Otávio Azevedo Mercadante, aprofunda alguns dos aspectos relacionados com as origens e transformações dos sistemas públicos de saúde do Brasil até a criação do Sistema Único de Saúde (SUS), em 1990, inspirado nos princípios e valores de universalidade, integralidade e solidariedade, consagrados na Constituição brasileira de 1988, assim como aborda a forma pela qual o SUS evoluiu até a data atual. Fornecem-se, neste capítulo, informações valiosas sobre os recursos disponíveis e o papel que o Estado assumiu para garantir o direito à saúde de todos os brasileiros. Discute-se, também, o papel da promoção da saúde, a partir das conclusões das grandes conferências mundiais sobre o tema, a fim de tornar ainda mais amplos os horizontes da saúde no Brasil. Indicam-se alguns dos desafios a serem considerados na consolidação do SUS, tendo em conta a necessidade de fortalecer operacionalmente a resolutividade e a qualidade dos serviços de saúde, na medida em que se avança nos processos de descentralização e regionalização e, igualmente, na medida em que cresce o número de interlocutores e parceiros, demandando um compartilhamento de responsabilidades quanto à condução, prestação e financiamento dos serviços de saúde no país. Essas sugestões se sustentam, em parte, em dois exercícios realizados recentemente. 0 primeiro, apoiado na metodologia Delphi, aplicada pelo IPEA em 2001; e o segundo, organizado em conjunto pelo Ministério da Saúde e pela OPAs, em 2002, com base em proposta que detalha as 'funções essenciais da Saúde Pública', seguindo recomendações aprovadas pelo Conselho Diretor da Opas.

Caminbos da Saude Pública no Brasil é produto do trabalho árduo e dedicado da autora do capítulo I e dos coordenadores dos dois outros capítulos, e traz a contribuição de inúmeras e destacadas personalidades da 
saúde pública brasileira, cujos nomes estão referidos em folhas que antecedem esta apresentação.

Queremos render tributo e reconhecimento aos doutores Walter Wyman, Rupert Blue, Hugh S. Cumming, Fred L. Soper, Abraham Horwitz, Hector Acuña, Carlyle Guerra do Macedo e George Alleyne, que, com sua visão, coragem e entusiasmo, construíram a mais antiga organização de cooperação técnica internacional especializada em saúde em nível mundial. Também gostaríamos de recordar e render homenagem aos que me antecederam como representantes da OPAS e da OMS no Brasil.

Para a Representação da Opas no Brasil, é motivo de grande honra e satisfação que Caminhos da Saúde Pública no Brasil seja co-editado com a parceria da Fundação Oswaldo Cruz (FIocruz), prestigiada instituição brasileira que celebrou seu centenário no ano 2000. A FIocruz, instituição do Ministério da Saúde, e a OPAs têm histórias convergentes em interesses e desafios.

Dedicamos este livro a todos, mulheres e homens, trabalhadores da saúde pública; aos cientistas e gestores, aos funcionários brasileiros da Opas e aos de outras nacionalidades, que elegeram, como desafio de vida, lutar pela contínua e permanente melhoria da saúde da população, no Brasil e nas demais regiões do continente e do mundo. 


\section{1 \\ 0 Brasil e a Organização Pan-Auericana da Saúde: UMA HISTÓRIA EM TRÊS DIMENSÕES}

Nísia Trindade Lima 
0 papel desempenhado pela saúde na configuração das relações internacionais a partir da segunda metade do século XIX ainda não foi suficientemente avaliado. A consciência a respeito do 'mal público', ${ }^{1}$ representado pelas doenças transmissíveis, e da necessidade de estabelecer medidas de proteção em níveis nacional e internacional contribuíram para a criação de fóruns e organismos de cooperação em escala mundial. Diferentes explicações poderiam ser enunciadas, mas deve-se destacar o crescente fluxo de mercadorias e pessoas, assim como o de doenças. Ações de proteção à saúde foram objeto de constantes debates e tentativas de normalização. Até mesmo quando a eminente eclosão de conflitos entre os Estados nacionais, em seu processo de expansão imperialista, colocou em evidência o tema da guerra, a agenda de saúde intensificou-se como questão internacional. As relações entre guerras e fenômenos mórbidos vêm merecendo, inclusive, a crescente atenção de historiadores que avaliam o impacto de epidemias çomo as de cólera na Europa do século XIX.

Do mesmo modo, pouco ainda se investigou por que o continente americano detém a primazia na cooperação internacional em saúde, a despeito da organização de Conferências Sanitárias Internacionais, desde 1851, na Europa. A industrialização e a expansão dos mercados no âmbito do desenvolvimento do capitalismo, com a conseqüente intensificação das trocas internacionais, não são condições suficientes para explicar tal fato. Determinadas doutrinas e ações possivelmente interferiram nesse processo, em particular o pan-americanismo e o crescente protagonismo dos Estados Unidos da América do Norte no continente.

A Organização Pan-Americana da Saúde (OPAs) é não só o mais antigo organismo de cooperação na área de saúde, mas também uma das primeiras instituições de cooperação internacional. A saúde foi o setor de ativi-

\footnotetext{
' Refiro-me a conceito de Wanderley Guilherme dos Santos, que define 'mal público' como fenômeno que atinge a todos os membros de uma coletividade, independentemente de terem contribuído para seu surgimento e disseminação. Segundo o autor, "ninguém pode ser impedido de consumir um bem coletivo, se assim o quiser (...) ninguém poderá se abster de consumir um mal coletivo, mesmo contra a sua vontade" (Santos, 1993: 52).
} 
dade em que as controvertidas idéias sobre pan-americanismo ${ }^{2}$ puderam, de algum modo, se expressar. De sua atuação, destaco neste texto, que se volta para as relações entre o Brasil e a OPAs, a idéia de que nem sempre tal papel deve ser aferido pelas influências mais diretas em termos de apoio ou desenvolvimento de programas relevantes nos países. Houve, desde as primeiras décadas do século $\mathrm{XX}$, crescente intercâmbio entre especialistas e gestores de saúde, e o papel do organismo deve também ser considerado em termos da construção de uma agenda comum e, de certo modo, de uma comunidade de especialistas. É esse papel de elaboração e divulgação de idéias que procuro avaliar neste trabalho. ${ }^{3}$

Uma história de cem anos com nítidas descontinuidades apresenta naturalmente uma série de dificuldades em seu processo de reconstituição. Qualquer tentativa de sistematização não fará justiça à diversidade de eventos e atores sociais. A proposta deste capítulo não poderia deixar de ser modesta - apresentar uma visão panorâmica, necessariamente incompleta, e sugerir esforço permanente de preservação da memória e de análise do processo histórico, cuja riqueza e relevância são aqui apenas brevemente anunciados.

Mas qual o papel da Opas nos diferentes períodos que se poderiam delimitar para a reconstituição de sua história? Nos documentos oficiais e nos balanços que marcam 0 ano do centenário, o papel de coibir as doenças transmissiveis, notadamente a febre amarela e a peste bubônica, de grande circulação entre os portos, destaca-se como ação preponderante em suas origens. Progressivamente, verificar-se-ia uma ampliação das ações e do próprio conceito de saúde que as fundamenta. Talvez o fator mais relevante a

\footnotetext{
20 tema merece análise mais cuidadosa, impossível de ser realizada nos limites deste trabalho. Os que 0 discutem tendem a diferenciar a corrente hispano-americana, que tem em Simon Bolívar o principal expoente, e a tese do pan-americanismo, na versão norte-americana, especialmente o que tem origem na chamada doutrina Monroe. Ver, a respeito, Veronelli \& Testa (2002).

${ }^{3}$ Este trabalho seria impossível sem a pesquisa e sistematização de fontes realizadas por Cristiane Batista. Agradeço às contribuições de Aline Junqueira, Cristina Fonseca e Lisabel Klein e aos profissionais da Representação da OpAs no Brasil, em particular ao Dr. Jacobo Finkelman.
} 
acompanhar a história da organização, não obstante o peso diferenciado quanto à formulação e à aplicação de políticas específicas, esteja na formação de uma base comum para o desenvolvimento da agenda de problemas e da adoção de políticas de saúde, particularmente nos países da América Latina e Caribe.

Com base nessa compreensão, este capítulo tem por objetivo apresentar em grandes linhas as características e diferenciações da história da OpAs durante estes cem anos, em sua relação com idéias, propostas de reforma sanitária, ações e políticas de saúde adotadas pelo Brasil. Nem sempre as relações são diretas, mas, como procurei demonstrar, o estudo da história da saúde no Brasil pode ser enriquecido ao se considerar a dimensão das relações interamericanas. As principais fontes utilizadas em sua elaboração foram os Boletins da Oficina Sanitária Pan-Americana, outros documentos oficiais e depoimentos de importantes lideranças no desenvolvimento das atividades da organização.

Para tornar mais claro o texto, optei por dividi-lo em seções. Na primeira, comentam-se as atividades até 1947, quando ocorreu importante mudança nos rumos da organização devido ao programa de descentralização, e sua transformação em organismo regional da Organização Mundial da Saúde (OMS), criada em 1946.

Na segunda seção, discutem-se os principais aspectos da gestão de Fred Soper, que dirigiu a Opas de 1947 a 1958. Durante esse período, com o fortalecimento da organização, estabeleceu-se cooperação mais efetiva com o governo brasileiro, evidenciada, entre outras medidas, pela criação do Centro Pan-Americano de Febre Aftosa (Panaftosa), pelo apoio ao laboratório de produção da vacina de febre amarela, na Fundação Oswaldo Cruz, e pela criação da Zona $V$ de representação regional, com sede no Rio de Janeiro.

$\mathrm{Na}$ terceira seção, apresentam-se os grandes temas que envolveram as relações do Brasil com a OPAS no período que se estende de 1958 a 1982, marcado pela relação entre desenvolvimento e saúde e pelas propostas de 
reforma do ensino médico. Os documentos que mais bem expressam os novos conceitos e propostas para a saúde são A Carta de Punta del Leste, firmada em 1961, e a Declaração de Alma-Ata, que, em 1978, definiu a meta "saúde para todos". A partir da década de 1950, observa-se também a presença da OPAs na criação de importantes instituições e inovações na área de saúde ambiental. No ensino médico, destaca-se, entre outras importantes iniciativas, a criação em 1967 da Biblioteca Regional de Medicina (BrReme), sediada em São Paulo.

$\mathrm{Na}$ década de1970, observam-se importantes nexos entre as ações da OpAs e a articulação inicial do movimento sanitarista no Brasil. Em um contexto marcado por regimes autoritários, acentua-se o papel desse organismo na revisão do ensino médico, na valorização das ciências sociais e no desenvolvimento da medicina social. Outros temas em destaque foram a erradicação da varíola no mundo, meta alcançada inicialmente nas Américas, e a criação do Programa Ampliado de Imunização, em 1976, pela OpAs/OMS.

$\mathrm{Na}$ quarta seção, discorre-se sobre as relações entre a Opas e o Brasil, a partir de 1982, quando foi eleito pela XXI Conferência Sanitária PanAmericana, realizada em Washington, o primeiro brasileiro a ocupar o cargo de diretor geral: Carlyle Guerra de Macedo. Discutem-se as principais iniciativas da Opas durante essa gestão, com ênfase nas que mais diretamente se relacionavam com o Brasil, procedendo-se do mesmo modo no que se refere à gestão de George Aleyne, com início em 1994. 0 foco principal da discussão encontra-se nos desafios colocados para a OPAs e para os países latino-americanos diante da crise econômica e das propostas de reforma do Estado, então em curso. 0 Brasil oferece neste contexto um campo bastante amplo de reflexões dada à implantação, em 1988, do Sistema Único de Saúde (SUS). Atenção especial é atribuída, finalmente, à proposta de ampliação da agenda de saúde para as Américas. 


\section{A agenda de saúde pública no Brasil e o papel das Conferências Sanitárias Pan- Americanas (1902-1947)}

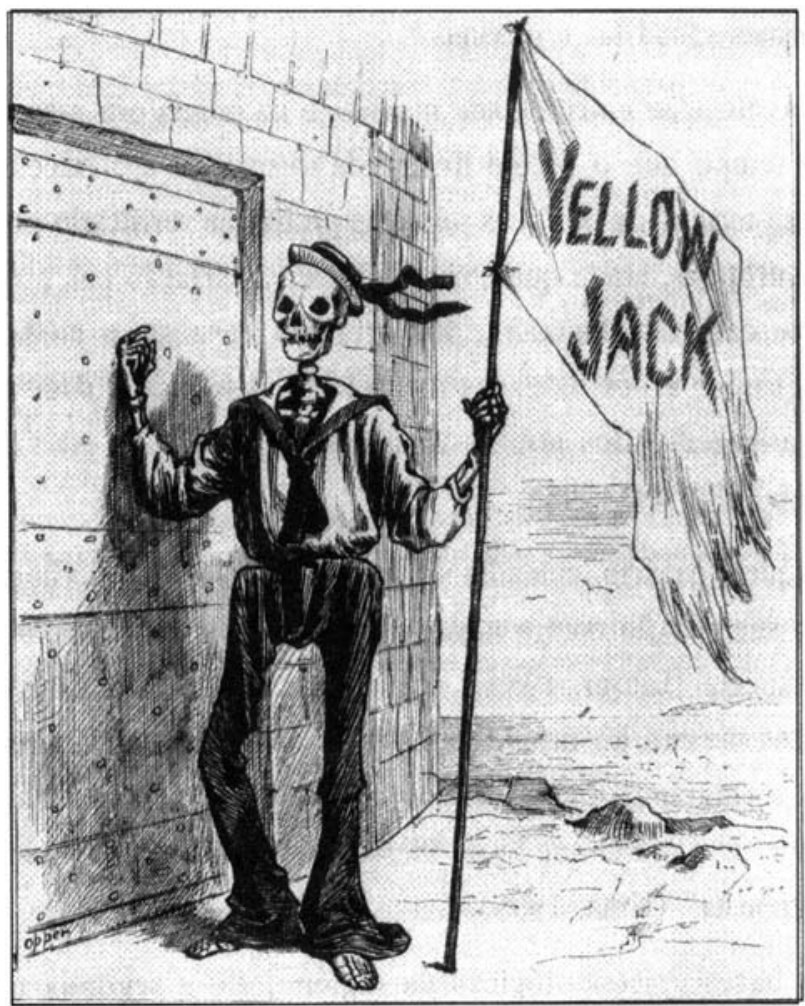

Representação iconográfica da ameaça representada pela febre amarela aos países da América.

Fonte : Opas, 1992.

\section{Saúde como questão internacional}

No século XIX, o conhecimento científico sobre as condições de saúde das coletividades humanas encontrava expressão no estudo da higiene, disciplina que se formava sob a influência do intenso processo de transformações pelo qual passavam as sociedades européias com 0 advento da 
industrialização e da urbanização. Londres, Paris, Berlim e, no continente americano, Nova Iorque, atingiram a marca de um milhão de habitantes naquele século, caracterizando o fenômeno da formação das sociedades de massas e de intenso processo de publicação de relatórios médicos e propostas de reformas sanitárias e urbanas. ${ }^{4}$

A associação entre cidade massiva e patologia era uma constante, ao mesmo tempo que o receio diante da desordem e a necessidade de respostas em termos de políticas públicas podia ser verificado nos diferentes países europeus, ainda que com significativa variação nas propostas de reforma. No caso da Alemanha, por exemplo, levaram o médico Rudolf Virchow a propor ações baseadas na idéia da responsabilidade dos médicos como advogados dos pobres e na caracterização da medicina como ciência social (Porter, 1998).

Naquele cenário, entendia-se por higiene o estudo do homem e dos animais em sua relação com o meio, visando ao aperfeiçoamento do indivíduo e da espécie (Latour, 1984). Alcançando notável desenvolvimento na França, antes mesmo do desenvolvimento da bacteriologia, a tentativa de normalizar a vida social, com base em preceitos ditados pela higiene, foi um fenômeno tão notável que levou Pierre Rosanvalon (1990) a falar de um "Estado higienista" (Lima, 1999).

As bases epistemológicas da higiene, até a segunda metade do século XIX, encontram-se no chamado neo-hipocratismo, "uma concepção ambientalista da medicina baseada na hipótese da relação intrínseca entre doença, natureza e sociedade" (Ferreira, 1996: 57). 0 neohipocratismo deu origem a duas posições que, durante os séculos XVIII e XIX, alternaram-se na explicação sobre as causas e formas de transmissão de doenças: a contagionista e a anticontagionista ou infeccionista (Ackerknecht, 1948).

\footnotetext{
${ }^{4} 0$ Rio de Janeiro, então capital da República dos Estados Unidos do Brasil, contava em 1900 com uma população de 700.000 habitantes.
} 
Segundo a concepção contagionista, uma doença podia ser transmitida do indivíduo doente ao indivíduo são pelo contato físico ou, indiretamente, por objetos contaminados pelo doente ou pela respiração do ar circundante. De acordo com tal concepção, uma doença causada por determinadas condições ambientais continuaria a se propagar, independentemente dos miasmas que lhe deram origem. As práticas de isolamento de doentes, a desinfecção de objetos e a instituição de quarentenas consistem em resultados importantes dessa forma de explicar a transmissão das doenças.

Já a concepção anticontagionista defendia o conceito de infecção como base explicativa para o processo de adoecimento, ou seja, uma doença era adquirida no local de emanação dos miasmas, sendo impossível a transmissão por contágio direto. Não é difícil avaliar as consequiências de um debate aparentemente restrito a pressupostos etiológicos. Com efeito, posições anticontagionistas desempenharam papel decisivo nas propostas de intervenção sobre ambientes insalubres - águas estagnadas, habitações populares, concentração de lixo e esgotos - e nas propostas de reforma urbana e sanitária, nas cidades européias e norte-americanas, durante o século XIX.

Ainda que seus pressupostos científicos tenham sido avaliados como equivocados após o advento da bacteriologia, os efeitos positivos da abordagem ambientalista para a melhoria das condições de saúde têm sido lembrados por vários estudos (Rosen, 1994; Duffy, 1990; Hochman, 1998). Alguns autores, entretanto, enfatizam as formas de controle sobre o comportamento social, as condições de trabalho, de habitação e alimentação das populações urbanas, indicando o processo normalmente entendido como medicalização da sociedade (Machado et al., 1978). Associados a pressupostos liberais e de defesa de reforma social (Ackerkenecht, 1948), ou identificados a posições de cunho autoritário, à semelhança da forma usual de se analisarem as teses contagionistas, os infeccionistas (ou anticontagionistas) lideraram importantes projetos e propostas de reforma sanitária. 
Essas posições devem ser vistas, no entanto, como tipos de causalidade e não como chaves classificatórias, nas quais devem ser enquadrados os médicos. Trata-se de explicações não necessariamente antagônicas, pois, muitas vezes, um médico atribuía ao contágio a origem de determinada doença, enquanto explicava outras como consequiência de miasmas. 0 próprio conceito de neo-hipocratismo tem merecido a atenção de trabalhos recentes em história da medicina. Neles, o neo-hipocratismo é visto como referência para concepções que pouco retinham dos fundamentos hipocráticos, a que recorriam, porém, em seu processo de legitimação (Gadelha, 1995).

Tanto na versão contagionista como na anticontagionista, uma das características mais marcantes da higiene no período que antecedeu a consagração da bacteriologia consistia na indeterminação da doença. ${ }^{5} 0$ ar, a água, as habitações, a sujeira, a pobreza, tudo poderia causá-la. A fluidez do diagnóstico era acompanhada pela imprecisão terapêutica. Essa característica também permitia que os higienistas atuassem como tradutores dos mais diversos interesses.

0 estudo de Bruno Latour (1984) sobre a consagração de Louis Pasteur e da bacteriologia na França traz um argumento pertinente à presente reflexão. 0 ponto mais relevante da análise do autor consiste em propor uma visão alternativa à consagrada em toda uma linha de história da medicina social. Estudos clássicos como o de George Rosen (1994), por exemplo, entendem que a bacteriologia teria gerado o abandono das questões sociais pela saúde pública. Tudo se resumiria à "caça aos micróbios", deslocandose a observação do meio ambiente físico e social para a experimentação confinada ao laboratório.

\footnotetext{
5Essa polarização representa uma simplificação do debate científico. Entre os extremos, podem ser historicamente identificadas nuanças nas concepções médicas sobre o que hoje denominamos doenças infectocontagiosas. Durante o século XIX, também encontramos explicações fundamentadas no conceito de contágio, consideradas válidas para algumas doenças, e a atribuição de causas infecciosas, para outras. No Brasil, isto fica claro nos estudos históricos sobre a febre amarela (Benchimol, 1999, 2001; Chalhoub, 1996).
} 
o que teria acontecido, segundo Latour, seria uma mudança nas representações sobre a natureza da sociedade. Em sua perspectiva, tratavase de uma lição de sociologia dada pelos pastorianos, uma vez que o que indicavam era a impossibilidade de se observar relações sociais e econômicas sem considerar a presença dos micróbios. Seria impossível identificar relações entre pessoas, pois os micróbios estariam presentes em toda parte, assumindo o papel de verdadeiros mediadores das relações humanas.

0 micróbio poderia mesmo promover a indistinção das barreiras sociais entre ricos e pobres, como afirmavam legisladores de fins do século XIX. Este ponto foi abordado de forma muito sugestiva pelo médico norteamericano Cyrus Edson, que, em fins do século XIX, apresentou o micróbio como "nivelador social". As ações públicas de saúde seriam uma decorrência do encadeamento de seres humanos e sociedades reveladores da "dimensão socialista do micróbio" (Hochman, 1996: 40). Em suma, o estudo dos micróbios entrelaçava-se fortemente ao da própria sociedade, redefinindo relações, formas de contato e as noções de pureza e de risco. ${ }^{6}$

As proximidades entre medicina e sociologia, durante o século XIX, têm sido lembradas por diferentes estudos que observam a transposição de teorias e metáforas, por exemplo, o recurso a metáforas baseadas em analogias orgânicas na proposta de filosofia social de Saint-Simon e na sociologia de Emile Durkheim.

0 estudo realizado por Murard \& Zylberman (1985) reforça o argumento até aqui apresentado. Os autores entendem que a higiene de fins do século XIX e início do século XX pode ser entendida como ciência social aplicada. Observam que, desde 1829 , anunciava-se o programa dos higienistas na França: a medicina não teria por objeto apenas estudar e combater as doenças; ela apresentava fortes relações com a organização

\footnotetext{
"É importante observar que não procedem tentativas de estabelecer uma relação de causalidade direta entre o conhecimento científico, mais especificamente o referido à bacteriologia, e sentimentos de aversão ao que é considerado impuro e perigoso à saúde. Este ponto é enfatizado especialmente nas obras de Norbert Elias (1990) e Mary Douglas (1976).
} 
social. As idéias divulgadas em periódicos, como os Annales d'Hygiène Publique et de Médicine Légale, em um momento marcado por ações de combate à cólera e à febre amarela, indicariam a articulação da medicina com problemáticas sociais.

À semelhança da análise de Latour, os autores observam que os pastorianos representaram, até certo ponto, uma continuidade em relação aos higienistas que discutiam anteriormente as idéias de transmissão das doenças. Consideravam um equívoco atribuir, à mudança nas explicações sobre contágio e à ênfase em pesquisas laboratoriais, uma alteração radical no que se refere ao escopo da ação dos higienistas. Em outras palavras, a ênfase no papel dos micróbios na transmissão das doenças não implicaria 0 abandono de temáticas sociais. Na verdade, deslocava-se a atenção, dirigida anteriormente para 0 meio ambiente, para as pessoas infectadas, acentuando-se os aspectos normalizadores da higiene sobre a sociedade.

A literatura tem sido mais atenta a esse ideal e discurso normalizador, deixando um pouco de lado o problema de como encontra efetividade no plano das relações sociais. Baseada fundamentalmente em fontes elaboradas por médicos do século XIX, muitas vezes o que se faz é reificar as interpretações elaboradas por eles sobre seu papel e capacidade de intervenção, reiterando o binômio cidade-doença, e as relações entre medicina e controle do espaço urbano.?

Em geral, os movimentos de reforma da saúde pública na Europa, quer na França, Alemanha ou Inglaterra, tenderam a se voltar para os cenários urbanos e, ainda que destacassem a associação cidade massiva e doença, revelavam certa dose de otimismo na crença de que a higiene permitiria intervir positivamente sobre 0 insalubre espaço urbano. 0 otimismo diante da possibilidade de intervenção científica compensava o sombrio diagnósti-

\footnotetext{
${ }^{7}$ Para uma crítica dessas tendências, na historiografia européia e na produção intelectual brasileira sobre medicina social, ver o artigo de Rezende de Carvalho \& Lima (1992).
} 
co associado à cidade que emerge com o advento do capitalismo industrial. ${ }^{8}$ Como vários estudos têm revelado, os narradores oitocentistas descrevem a cidade como cenário privilegiado de observações das manifestações mais perversas das novas relações de trabalho e sociabilidade. A cidade, então, passa a ser vista como "laboratório social", onde se poderiam observar os aspectos disruptivos da nova ordem: a fome, a doença, a embriaguez e a loucura (Rezende de Carvalho \& Lima, 1992).

Não se deu apenas no plano interno às nações o impacto do fenômeno urbano e dos novos conhecimentos relativos à saúde. Importante dimensão desse processo ocorreu nas relações internacionais, com a intensificação do comércio e as implicações negativas da instituição das quarentenas nos portos marítimos. As controvérsias científicas ocorreriam também nos primeiros fóruns internacionais criados no campo da saúde: as Conferências Sanitárias Internacionais.

A doença mais marcante durante o século XIX foi o cólera, dando origem à que foi considerada a primeira pandemia no período de 1817-23, e que atingiu progressivamente países do Golfo Pérsico e aqueles banhados pelo Oceano Índico. 0 padrão tradicional da expansão dessa doença se viu alterado pela maior densidade do comércio internacional e dos movimentos militares derivados da dominação britânica na Índia. Uma segunda pandemia ocorreu em 1826, atingindo desta vez a Rússia, o Báltico e finalmente a Inglaterra (Veronelli \& Testa, 2002). A terceira atingiu a América (1852-59) e a quarta, com início em 1863, chegou a Nova Iorque em 1863, Buenos Aires em 1866 e, em 1867, à região onde se deflagrava a Guerra do Paraguai, afetando as tropas aliadas e paraguaias. ${ }^{9}$

Sob o impacto das epidemias de cólera e febre amarela, realizou-se em Montevidéu, em 1873, uma convenção sanitária em que se firmou uma

\footnotetext{
${ }^{8}$ Esse ponto fica muito claro no estudo de George Rosen (1979) sobre a história do conceito de medicina social. Segundo o autor, esse conceito está intimamente associado ao desenvolvimento do capitalismo e à emergência das questões social e urbana.

${ }^{9}$ Consta que Francisco Solano López, líder paraguaio, também contraiu a doença.
} 
ata pelo Brasil, Argentina e Uruguai determinando medidas comuns de prevenção em relação a doenças como cólera asiático, febre amarela, peste e tifo. Em 1887, realizou-se, no Rio de Janeiro, novo colóquio entre esses países em que se estabeleceu a Convenção Sanitária do Rio de Janeiro (Veronelli \& Testa, 2002).

A experiência das epidemias de cólera no século XIX, na Europa e nos Estados Unidos, teve papel determinante na percepção das elites políticas sobre os problemas sanitários, favorecendo ações políticas, criação de organizações e intervenção dos Estados nacionais na resolução dos problemas de saúde e nas reformas urbanas (Briggs, 1961). Sua conotação de pandemia implicou não apenas a transformação da saúde em problema de natureza coletiva em sociedades particulares, mas sua compreensão como tema de política internacional. A constituição de sistemas sanitários representa capítulo importante na constituição do Estado de Bem-Estar (De Swaan, 1990; Hochman, 1998) e, ao mesmo tempo, processo crucial para a percepção das doenças transmissíveis como tema central na configuração das relações internacionais.

Foi nesse quadro que, em meados do século XIX, tiveram início as Conferências Sanitárias Internacionais, fóruns de debate científico sobre as controvérsias em torno das causas e dos mecanismos de transmissão de doenças, e político, uma vez que se tratava de estabelecer normas e procedimentos comuns entre os países que enfrentavam problemas como as epidemias de cólera e de peste bubônica. Essas conferências reuniam basicamente países europeus e expressavam a contradição entre a crescente insegurança - em face da ampliação das epidemias e da própria emergência do conceito de pandemia - e a idéia de progresso que se afirmava e encontrava representação simbólica nas Grandes Exposições Internacionais. Sugestivamente, a primeira Conferência Sanitária e a primeira Exposição Internacional ocorreram no mesmo ano, 1851, respectivamente em Paris e Londres (WHO, 1958). 
Oito anos após este colóquio e na mesma cidade, foi realizada a segunda Conferência. A terceira Conferência realizou-se em 1866, em Constantinopla, e a seguinte, em Viena, em 1874. A quinta Conferência Sanitária Internacional foi a primeira a se realizar no continente americano e teve lugar em Washington em 1881. Aristides Moll, editor científico da Oficina Sanitária Pan-Americanana, nas décadas de 1920 e 1930, chegou a apontá-la como a primeira conferência sanitária pan-americana (Veronelli \& Testa, 2002; Moll, 1940). Entretanto, a representação dos países americanos era basicamente dos corpos diplomáticos, com reduzida presença das autoridades sanitárias nacionais.

Um dos fatos mais significativos, durante a quinta Conferência, foi a participação de Carlos Finlay, delegado especial de Espanha, representando Cuba e Porto Rico. Finlay apresentou sua teoria sobre a transmissão da febre amarela, considerando-a como uma concepção alternativa aos argumentos contagionista e anticontagionista. A posição do cientista estava fundamentada na seguinte hipótese: a presença de agente inteiramente independente para a existência tanto da doença como do homem doente, mas absolutamente necessário para que a enfermidade fosse transmitida do portador da febre amarela ao indivíduo são. Este agente, ou vetor, era um mosquito, e sua hipótese só foi considerada plenamente demonstrada vinte anos depois. ${ }^{10}$

Apenas em 1903, na sexta Conferência, consideraram-se como fatos científicos estabelecidos o papel do rato na transmissão da peste e do Stegomia fasciata (atualmente Aedes aegypti) na transmissão da febre amarela. Essa resolução teve evidentes efeitos práticos, de crucial importância para o intercâmbio e comércio internacionais, devido ao problema acarretado pela quarentena dos navios.

\footnotetext{
${ }^{10}$ Antes de Finlay, investigaçôes sobre a transmissão da malária levaram alguns médicos a sugerir vínculos entre mosquitos e febre amarela, como foi o caso de e John Crawford, em 1807. Também Louis Daniel Beauperthuy (1825-1871), médico e naturalista francês que trabalhou na Venezuela, apresentou a hipótese da transmissão da febre amarela por mosquitos (Cueto, 1996a).
} 
Os debates sobre a transmissibilidade das doenças nunca foram estritamente científicos. No que se refere à imposição de quarentenas, a politização do tema seria flagrante uma vez que interferiam no fluxo comercial, no comércio internacional e no deslocamento populacional. 0 cólera, a peste e a febre amarela eram as três doenças em relação às quais havia maior atenção dos países; seu significado transcendia ações específicas de combate e consistiram importantes elementos na própria configuração e reconfiguração dos Estados modernos.

No caso das Américas, a febre amarela, em fins do século XIX e início do século $\mathrm{XX}$, era considerada o grande desafio de política sanitária, especialmente no que se refere ao comércio entre as nações. Em parte, desempenhou no continente americano papel similar ao do cólera na Europa. Foi uma das doenças mais marcantes da história da saúde pública brasileira, com impactos sobre os processos políticos e o desenvolvimento científico no país.

\section{Brasil: imenso hospital}

As imagens que associam o Brasil a doenças, especialmente às de natureza transmissível, ao contrário do que a primeira impressão pode indicar, são relativamente recentes em nossa história. Até a segunda metade do século XIX, prevalecia a idéia de "um mundo sem mal", caracterizado por uma natureza e um clima benévolos e pela longevidade de seus habitantes, conforme expressão utilizada por Sérgio Buarque de Holanda, em Visões do Paraíso, para se referir às impressões suscitadas pelos textos de cronistas e viajantes (Lima, 2000).

A despeito de registros de incidência de varíola e febre amarela desde o período colonial, no início do século XIX, as referências a um país saudável ainda eram freqüentes. As principais cidades, particularmente o Rio de Janeiro, então capital do Império, que, no final daquele século, era 
considerada um celeiro de doenças, não eram vistas do mesmo modo, tal como se pode observar no discurso do renomado médico Francisco de Mello Franco:

Não só pelo que tenho observado por mim mesmo, mas segundo o que tenho inquirido de médicos que, por muitos anos com grande reputação, têm praticado nesta capital do Brasil, não se encontra febre alguma contagiosa (...) o que na verdade maravilha a quem exercitou a clínica na Europa, onde o contágio de algumas febres é conhecido até mesmo do povo. (Ferreira, 1996: 96)

0 impacto da epidemia de febre amarela no Rio de Janeiro, de 1849 a 1850 , alterou sensivelmente essa imagem pública. 0 fato de ter feito vítimas fatais na elite favoreceu a compreensão do quadro sanitário do Brasil como um problema científico e político importante, ampliando a repercussão das polêmicas médicas sobre 0 assunto.

As controvérsias sobre as origens, causas e formas de transmissão das doenças infecciosas são inúmeras e têm sido bastante documentadas nos estudos sobre história da medicina e nas pesquisas históricas sobre 0 Rio de Janeiro (Benchimol, 1999). Do "mundo sem mal", passou-se a lidar com expressões opostas, como a de Rui Barbosa que, em discurso de homenagem póstuma a Oswaldo Cruz, em 1917, referiu-se ao Brasil como o "país da febre amarela". No mesmo texto, o intelectual baiano afirmava que, ao debelar a epidemia dessa enfermidade no Rio de Janeiro, Oswaldo Cruz promovera a efetiva "abertura dos portos às nações amigas" (Barbosa, 1917). Cada doença evocava, por sua vez, uma série de temas que despertavam inevitáveis tensões sociais; entre elas, as motivadas pela referência a diferentes padrões imunológicos dos grupos étnicos que formavam o Brasil. Consideravase, por exemplo, que a febre amarela vitimava mais os brancos e os imigrantes europeus do que a população de origem africana (Chalhoub, 1996).

No início do século $\mathrm{XX}$, o surto de peste bubônica que assolou Santos viria agravar o quadro sanitário e a percepção pública sobre os riscos representadas pelas epidemias. A criação do Instituto Butantan, em São 
Paulo, e do Instituto Soroterápico Federal, atual Fundação Oswaldo Cruz, no Rio de Janeiro, foram iniciativas importantes, com impacto decisivo no desenvolvimento das ciências biomédicas e na saúde pública (Stepan, 1976; Benchimol, 1990a; Benchimol \& Teixeira, 1993).

A história da saúde pública no Brasil é, em larga medida, uma história de combate aos grandes surtos epidêmicos em áreas urbanas e às denominadas endemias rurais, como a malária, a doença de Chagas e a ancilostomose. Em contraste com o que ocorrera durante as epidemias de febre amarela, essa doença afetava indistintamente brancos e negros e chegou a ser apontada como principal responsável pela apatia do trabalhador brasileiro e pela "nacionalização" do imigrante europeu. Sua presença em textos de médicos, de leigos, e em representações iconográficas foi muito intensa e alcançou expressão em um dos mais importantes personagenssímbolo dos pobres na literatura brasileira: o Jeca Tatu de Monteiro Lobato.

A crítica às perspectivas ufanista e romântica sobre a natureza e o homem brasileiros e a ênfase nos males do Brasil aproximaram o discurso médico de textos literários e ensaísticos que se propuseram a esboçar retratos do país. Especialmente no período da Primeira Guerra Mundial, a afirmação da nacionalidade, que encontrou expressão em movimentos como a Liga de Defesa Nacional, confrontava-se com a denúncia feita por médicos, educadores e outros profissionais de que 0 analfabetismo e a doença estavam presentes em todo o território. Consta inclusive que a célebre frase "o Brasil é um imenso hospital", proferida pelo médico Miguel Pereira, em 1916, foi uma reação a discursos enaltecedores da força e da higidez dos sertanejos que, se convocados, garantiriam a integridade territorial e política do país (Lima, 1999; Lima \& Hochman, 1996).

A campanha pela reforma da saúde pública e pelo saneamento dos sertões alcançou repercussão nacional com a publicação de uma série de artigos de Belisário Penna no jornal Correio da Manbã, em 1917, reunidos posteriormente no livro Saneamento do Brasil (1918). Tratava-se, segun- 
do expressão de Miguel Couto (apud Britto, 1995: 23), presidente da Academia Nacional de Medicina, de lançar uma "cruzada da medicina pela pátria"; ao médico cabia substituir a autoridade governamental, ausente na maior parte do território nacional. Nessa cruzada, fazia-se sentir a crítica à oligarquização da República, especialmente ao princípio da autonomia estadual, que impedia uma ação coordenada, em nível federal, capaz de promover o combate às epidemias e endemias e melhorar as condições de saúde da população.

A campanha sensibilizou progressivamente nomes expressivos das elites intelectuais e políticas do país e teve como um dos marcos mais significativos a criação da Liga Pró-Saneamento do Brasil, em fevereiro de 1918, em sessão pública na Sociedade Nacional de Agricultura. A leitura da ata da fundação demonstra o interesse em reunir nomes expressivos nos meios militares, entre os engenheiros, médicos e advogados, além de parlamentares e do próprio presidente da República, Wenceslau Braz, que ocupou o cargo de presidente honorário. Miguel Couto, Carlos Chagas Juliano Moreira, Rodrigues Alves, Clovis Bevilacqua, Epitácio Pessoa ${ }^{11}$ Pedro Lessa, Aloysio de Castro ${ }^{12}$ e Miguel Calmon integravam o conselho supremo da associação. Um dado interessante consistiu na formação de delegações regionais em vários estados e na designação do então coronel Cândido Rondon para presidir a delegação de Mato Grosso (Saúde, 1918, n. 1).

Ainda que congregasse tantos nomes de expressão, apresentandose como um movimento de caráter amplo, orientado por um nacionalismo que queria resgatar as "coisas nacionais" e livrar o país dos males representados pela doença, a campanha do saneamento enfrentou vários obstáculos, não conseguindo aprovar no Congresso Nacional uma de suas principais

\footnotetext{
${ }^{1}$ Presidente da República no quinquênio seguinte, Epitácio Pessoa ocupava na época o cargo de senador. ${ }^{12}$ Aloysio de Castro era o diretor da Faculdade de Medicina do Rio de Janeiro. Miguel Couto, presidente da Academia Nacional de Medicina àquela época, foi eleito presidente do conselho supremo. Na prática, a Liga Pró-Saneamento foi dirigida pelo diretor-presidente do diretório executivo, o higienista Belisário Penna.
} 
propostas: a criação do Ministério da Saúde.$^{13}$ A solução para uma maior centralização das ações sanitárias no âmbito federal ocorreu em 1920, com a criação do Departamento Nacional de Saúde Pública, dirigido desde sua fundação até 1926 pelo cientista Carlos Chagas.

Note-se que esse tema - a unificação dos serviços de saúde e a constituição de uma autoridade sanitária nacional - esteve também fortemente presente no debate da Opas. Como veremos com mais detalhes, dessa geração de cientistas, Oswaldo Cruz, Raul de Almeida Magalhães e Carlos Chagas representaram o Brasil na condição de delegados nas Conferências Pan-Americanas de Saúde, e os dois últimos participaram também do corpo diretivo da organização.

A construção de uma identidade profissional mais delimitada pode também ser relacionada às mobilizações dos anos de 1910 e 1920. A ênfase na saúde coletiva e nas chamadas endemias rurais marcou a constituição do Departamento Nacional de Saúde Pública e a formação de novas gerações de profissionais. 0 termo sanitarista substituiu progressivamente a referência tradicional aos higienistas, indicando especialização profissional e maior distinção entre as atividades científicas no laboratório e as atividades de saúde pública. Tal processo não ocorreu isoladamente no Brasil e contou com a participação ativa da Fundação Rockefeller no ensino médico, como foi o caso da criação da cadeira de higiene na Faculdade de Medicina de São Paulo, em 1918 (Castro Santos, 1987, 1989). Muitos profissionais brasileiros completaram seu processo de especialização, nas décadas de 1920 , 1930 e 1940, na Escola John Hopkins de Higiene e Saúde Pública, importante centro de pesquisa e ensino financiado pela Fundação Rockefeller nos Estados Unidos (Fee, 1987).

Um dos efeitos mais notáveis da campanha consistiu na criação dos postos de profilaxia rural em diferentes estados, que significaram, ainda que

\footnotetext{
${ }^{13}$ A análise da relação entre o movimento sanitarista e a implementação de políticas de saúde está desenvolvida nos trabalhos de Castro Santos (1987) e Hochman (1998).
} 
pequeno fosse o resultado para a melhoria das condições de vida, a presença do Estado na implementação de políticas de atenção à saúde de populações que, como afirmaram Arthur Neiva e Belisário Penna (1916: 199), só sabiam de governos "porque se lhes cobravam impostos de bezerros, de bois, de cavalos, de burros". Ainda é possível afirmar que a campanha transformou em problema social, tema de debate público, uma questão que até aquele momento encontrava-se em foco especialmente nos periódicos médicos - a doença e 0 abandono como marcas constitutivas das áreas rurais do Brasil. ${ }^{14}$

Entre os estudos que se dedicaram a analisar as políticas de saúde pública durante a Primeira República, o de Luiz Antônio de Castro Santos trouxe uma contribuição relevante ao propor uma abordagem mais processual para as relações entre movimento sanitarista, políticas de saúde e construção da nacionalidade, acentuando que causas diversas poderiam ser apontadas. Identificou duas fases das ações sanitaristas durante a Primeira República: a primeira voltada ao combate às epidemias urbanas, quando as preocupações com a saúde dos imigrantes desempenharam papel central; a segunda, ao saneamento rural, em que se fez sentir a força das idéias nacionalistas então em debate (Castro Santos, 1985, 1987).

0 papel que o movimento pela reforma da saúde pública desempenhou na consolidação do Estado nacional no Brasil foi bem explorado por Gilberto Hochman (1998), que, com base no conceito de interdependência social, relacionou as possibilidades de expansão territorial da autoridade pública ao impacto das idéias científicas sobre transmissibilidade de doenças. Os caminhos trilhados pelos sanitaristas nesse periodo, a partir da abordagem da doença como principal problema nacional, interagiram decisivamente com questões cruciais da ordem política brasileira: as relações entre o público e o privado e entre poder local e poder central. Temas que, ademais, desnecessário lembrar, permanecem de evidente atualidade.

\footnotetext{
${ }^{14}$ Deve-se notar que, dificilmente, os debates no campo médico restringiam-se aos periódicos especializados. Artigos tratando de polêmicas científicas eram publicados nos jornais da grande imprensa. Ver a respeito os trabalhos de Benchimol (1999) e Ferreira (1996).
} 
0 debate sobre a identidade nacional no Brasil tem origens muito anteriores, mas alcançou considerável expressão durante a Primeira República, uma vez que muitos intelectuais associaram, a essa forma de governo, o ideário do progresso e a afirmação do processo civilizatório em um país que parecia estar condenado por seu passado colonial e escravista, e pela propalada inferioridade racial de sua população. Os intelectuais que participaram da campanha do saneamento partiam de uma crítica à idéia da inviabilidade do país como nação, contestando qualquer tipo de fatalismo baseado na raça ou no clima, ao mesmo tempo que se opunham às versões ufanista e romântica que consideravam idealizar a natureza e o homem brasileiros. ${ }^{15}$

Entre os principais resultados do movimento de reforma da saúde durante a Primeira República (1889-1930), destaca-se a consolidação da imagem de uma sociedade marcada pela presença das doenças transmissíveis, o que, de forma satírica, encontraria, mais tarde, expressão em Macunaíma, de Mario de Andrade: "Pouca saúde, muita saúva: os males do Brasil são".

\section{A organização da saúde nas décadas de 1930 e 1940: de imenso hospital a laboratório de saúde pública}

Os estudos históricos sobre a constituição da área de saúde no Brasil têm privilegiado o período da Primeira República, o que em parte pode ser explicado pela centralidade política que o tema recebeu e sua percepção como problema-chave - problema vital, como o denominou Monteiro Lobato. Foi o período da proposta da primeira reforma sanitária, cuja tônica radica-

\footnotetext{
${ }^{15} 0$ ufanismo, termo utilizado em estudos recentes para se referir à corrente de pensamento que propunha a autocongratulação dos brasileiros, encontrou sua expressão máxima no livro Porque me Ufano de meu País, do monarquista Conde de Afonso Celso (Oliveira, 1990; Carvalho, 1994).
} 
va-se na crítica à oligarquização do país e à ausência de uma ação coordenada em nível nacional. Foi também o período das primeiras reformas urbanas, da busca de sua europeização, seguindo principalmente o modelo da Paris de Haussman (Benchimol, 1990b).

Essa visibilidade das questões referidas à saúde nas três primeiras décadas do século XX possivelmente contribuiu para ofuscar processos importantes nos momentos posteriores que antecederam a criação do Ministério da Saúde em 1953. 0 fato é que, a partir da década de 1920, com a criação do Departamento Nacional de Saúde Pública, começou a ser gestado o modelo centralizado de longa sobrevivência na área. Após a criação do Ministério de Educação e Saúde, em 1931, e principalmente com a reforma implementada pelo ministro Gustavo Capanema, em 1941, a estrutura verticalizada e centralizadora encontraria expressão com a criação dos Serviços Nacionais de Saúde.

A constituição de um aparato estatal na área de saúde iniciou-se efetivamente nos anos 1920, ganhando caráter nacional e acelerando-se na década seguinte, ao mesmo tempo que se diferenciaram dois setores: a saúde pública e a medicina previdenciária. A década de 1930 representou um momento decisivo tanto pelo estabelecimento da proteção social, com base em um conceito de cidadania regulada pelo mundo das profissões (Santos, 1979), quanto pela reforma no âmbito das ações de saúde. A reforma administrativa no Ministério da Educação e Saúde, em 1941, implicou a verticalização, centralização e ampliação da base territorial de efetiva ação do governo federal, cuja característica anterior era o excessivo peso no Distrito Federal.

A estrutura verticalizada e organizada por doenças é uma das características da história da saúde pública no Brasil que se manteria nos anos posteriores (Fonseca, 2001), 0 exame do organograma de 1942 do Departamento Nacional de Saúde, subordinado ao Ministério da Educação e Saúde revela uma estruturação voltada para doenças es- 
pecíficas, naquele momento organizadas por serviços nacionais: de febre amarela, malária (ao qual se subordinavam ações profiláticas contra doença de Chagas e esquistossomose), câncer, tuberculose, lepra e doenças mentais.

Alguns sanitaristas com atuação relevante nesse contexto, muitos com formação especializada na Universidade John Hopkins, viriam posteriormente a desempenhar papel de destaque na Opas. Entre os nomes com expressiva atuação, no período e em décadas subseqüentes, destacam-se João de Barros Barreto, Mario Pinotti, Geraldo de Paula Souza, Manoel Ferreira, Marcolino Candau e Ernani Braga. Estudos mais extensos e aprofundados sobre sua trajetória e seu papel na saúde pública consistem em importante ponto para uma agenda de pesquisa em história da saúde pública no Brasil. Note-se, inclusive, que Marcolino Candau foi também o segundo diretor geral da OMS, cargo que ocupou de 1953 a 1973.

No caso de João de Barros Barreto, pode-se dizer que representou a autoridade sanitária do país no período mais extenso à frente da política nacional de saúde. Diretor do Departamento Nacional de Saúde, entre 1938 e 1945, foi responsável pela extensão dos postos de saúde no território nacional e pela consolidação da estrutura verticalizada dos serviços de combate às doenças. Atribuiu também prioridade ao registro estatístico das campanhas de saúde pública, contribuindo para a implantação de um sistema de informações sobre as doenças transmissíveis e a captura de vetores.

Essa geração, que teria momentos importantes de sua trajetória profissional, durante o Estado Novo, mantinha laços com as lideranças de saúde pública nos Estados Unidos e participara das instituições que orquestraram com 0 governo brasileiro agências e programas de forte impacto no combate a epidemias de febre amarela e malária, caso dos serviços estabelecidos em consórcio com a Fundação Rockefeller e das ações do Serviço Especial de Saúde Pública (SEsP), criado em 1942. No caso deste último, observa Marcolino Candau: 
os Ministros das Relações Exteriores das Repúblicas Americanas realizaram, de 15 a 28 de janeiro de 1942, no Rio de Janeiro, uma Reunião de Consulta, cuja ata final documenta, no capítulo "Melhoramentos em Saúde Pública", esse importante marco da história desse campo de ação governamental (...) Dessa reunião resultaram entendimentos entre os Governos do Brasil e dos Estados Unidos da América que levaram à criação, em 1942, no Ministério da Educação em Saúde, de um Serviço Especial de Saúde Pública destinado a desenvolver inicialmente no Vale do Amazonas e, em seguida, no Vale do Rio Doce, atividades gerais de saúde e saneamento que também incluiriam o combate à malária, a assistência médico-sanitária dos trabalhadores ligados ao desenvolvimento econômico das duas regiōes (...), o preparo e o aperfeiçoamento de médicos e engenheiros sanitaristas, de enfermeiras e outros profissionais de saúde. (apud Braga, 1984: 104)

0 que vale a pena destacar é o fato de esses programas terem tido impacto relevante na formação ou consolidação da liderança de sanitaristas brasileiros e, mais do que isso, o fato de o Brasil poder ser considerado um grande laboratório de conhecimentos e práticas de saúde pública, de crucial importância na trajetória também dos norte-americanos. Fred Soper talvez seja o mais notável exemplo desse fato. Em suas memórias, a experiência no Serviço de Febre Amarela e na campanha de erradicação do Anopheles gambiae é realçada como elemento decisivo para a atuação posterior em outros países da América e da África. De imenso hospital, o Brasil transformara-se em grande laboratório e escola para as campanhas de saúde pública e formação de um novo tipo de sanitarismo.

\section{Brasil e a atuação da OPAS em sua primeira fase}

No longo período que se estende da criação da OPAS até 1947 , pode-se afirmar que dois elementos foram os mais relevantes em sua relação com os países que a integravam: a difusão de idéias científicas e relacionadas a ações de saúde - principalmente por meio das Conferên- 
cias Sanitárias Pan-Americanas e do Boletim da Oficina Sanitária PanAmericana ${ }^{16}$ - e a proposta de regulação da notificação e formas de combate às doenças transmissíveis com a aprovação do Código Sanitário Pan-Americano em 1924.

No Brasil, o debate e as campanhas contra a febre amarela e seu vetor ocupavam posição de destaque, o que se estenderia até a década de 1950, com a criação de um programa de erradicação do Aedes aegypti para o continente americano. Seria simplificador, no entanto, observar, apenas do ponto de vista das ações de combate a essa doença, as relações e as influências recíprocas entre os fóruns promovidos pela Opas e as ações de saúde pública realizadas no Brasil. Não existem muitas fontes sobre a atuação de brasileiros nesse organismo, mas, principalmente pelas Conferências Pan-Americanas, podem-se levantar algumas possibilidades de interpretação. É possivel identificar, no âmbito desses fóruns, temas que constituíam a agenda de saúde pública no Brasil, principalmente a idéia de reforma da saúde pública com a criação de um Ministério da Saúde.

Em janeiro de 1902, na cidade do México, realizou-se a segunda Conferência Internacional dos Estados Americanos. Atendendo à recomendação de seu Comitê de Política Sanitária Internacional, a Conferência aprovou a convocação de uma convenção geral de representantes dos organismos sanitários das repúblicas americanas para decidir sobre a notificação de enfermidades, o intercâmbio dessa informação entre as repúblicas, a realização de convenções periódicas sobre a matéria e o estabelecimento de uma oficina permanente em Washington para coordenar essas atividades. A primeira Convenção Sanitária Internacional foi realizada em Washington, de 2 a 4 de dezembro de 1902, e criou a Oficina Sanitária Internacional, que funcionou como apêndice do serviço de saúde pública dos EUA, acumulando o Cirurgião Geral, chefe desse serviço, a direção da Oficina Sanitária Internacional até 1936 (OPAs, 1992; Macedo, 1977; Bustamante, 1972).

\footnotetext{
${ }^{16}$ Passarei a me referir à publicação como Boletim. Nas referências bibliográficas empregarei a sigla Bosp.
} 
Em 1905, realizou-se a segunda Convenção Sanitária, que estabeleceu propostas relativas a quarentenas e notificação de enfermidades no continente. Seria, segundo alguns autores, a precursora do Código Sanitário Pan-Americano. Em dezembro de 1907, teve lugar a terceira na cidade do México, cabendo a Oswaldo Cruz representar o Brasil. Em 1909, na Costa Rica, ocorreu a quarta reunião em que se propôs a mudança do nome Convenção para Conferência e, em 1911, a quinta Conferência, realizada em Santiago do Chile, em que se decidiu nomear a Oficina como Oficina Sanitária Pan-Americana, responsabilizandoa pela elaboração de um projeto de Código Sanitário Marítimo Internacional. Representaram o Brasil Ismael da Rocha e Antonino Ferrari (Barreto, 1942).

Com a eclosão da Primeira Guerra Mundial, houve um longo intervalo e, em 1920, na cidade de Montevidéu, realizou-se a sexta Conferência Sanitária Internacional, em que compareceu como delegado brasileiro Raul Leitão da Cunha. A Conferência ratificou o nome do Cirurgião Geral do Serviço de Saúde dos EUA, Hugh Cumming, como Diretor da Oficina, posição que ocupou até 1947, apesar de ter deixado o cargo de Cirurgião Geral dos EUA em 1936. Nessa conferência, deliberou-se pela criação do Boletim Pan-Americano de Saúde, publicado mensalmente a partir de 1922, cujo nome foi alterado posteriormente para Boletim da Oficina Sanitária Pan-Americana. Na VI Conferência Sanitária, a Oficina definiu sua reestruturação. Pouco a pouco, estendeu seu raio de ação e constituiu um centro consultor (Ata da IX Conferência).

Em Havana, 1924, na VII Conferência Sanitária Pan-Americana, contando com Uiz do Nascimento Gurgel e Raul de Almeida Magalhães como delegados do Brasil, aprovou-se o projeto do Código Sanitário Marítimo Internacional, logo designado como Código Sanitário Pan-Americano. Esse documento foi objeto de discussões posteriores pelo Poder Legislativo de cada país integrante do organismo, para efeito de ratificação, e definiram-se como suas finalidades (Soper, 1948):

1) prevenir a propagação internacional de infecções ou doenças suscetíveis de serem transmitidas a seres humanos; 
2) estimular e adotar medidas cooperativas destinadas a impedir a introdução e a propagação de doenças nos territórios dos governos signatários ou procedentes dos mesmos;

3) uniformizar o registro de dados estatísticos relativos à morbidade nos países dos governos signatários;

4) estimular 0 intercâmbio de informes que possam ser valiosos para melhorar a saúde pública e combater as enfermidades próprias do homem.

Quatro anos mais tarde, em Lima, a VIII Conferência estabeleceu um Conselho Diretor para a Oficina e aprovou que ela atuasse coletando dados para a Oficina Internacional de Saúde Pública, criada em 1907, com sede em Paris (Bosp, ano 7, n. 1, jan. 1928). Representado por João Pedro de Albuquerque e Bento 0swaldo Cruz, o Brasil levou, para esse colóquio, informe sobre saúde materno-infantil e seus progressos no país, apresentando documento elaborado por Antonio Fernandes Figueira. A despeito dos trabalhos históricos sobre a OpAs ressaltarem o papel da VII Conferência, devido à aprovação do Código Sanitário, o exame do colóquio realizado em Lima requer análise mais cuidadosa, uma vez que demonstra preocupações que superavam as medidas sanitárias nos portos.

Isso não significa que o Código Sanitário Pan-Americano não se mantivesse como tema central, algumas discussões detendo-se no caráter de recomendação ou obrigatoriedade dos artigos do documento. Nesse debate, uma referência importante foi a participação de Carlos Chagas em 1926 na Conferência Sanitária Internacional, realizada em Paris. 0 cientista brasileiro defendera a proteção dos países do Atlântico, quanto a doenças resultantes do intenso fluxo migratório, e redigiu o texto sobre os princípios técnicos e científicos da profilaxia da febre amarela.

Como mecanismo de cooperação técnica, instituiu-se o cargo de Comissários Itinerantes (viajeros) - funcionário dos serviços nacionais de saúde que poderiam ser cedidos à Oficina e que deveriam prestar colaboração às autoridades sanitárias dos países signatários. A VIII Conferência aprovou tam- 
bém um anexo ao Código Sanitário e definiu o processo de ratificação, completado apenas em 1936, com a assinatura pelas 21 repúblicas existentes na América. 0 processo de ratificação teria mesmo de ser longo, pois implicava aprovação das medidas preconizadas pelo Poder Legislativo dos países americanos.

As conferências sanitárias, ao incluírem como ponto central de seu programa os informes dos países, contribuem para que se compreenda a importância de algumas enfermidades, aspectos do quadro sanitário e ações em curso. No caso da VIII Conferência, encontram-se, por exemplo, evidências sobre semelhanças do quadro sanitário dos Estados Unidos em relação aos demais países americanos. A delegação norte-americana, formada por Hugh S. Cumming, John Long e Bolívar Lloyd, apresentou informe sanitário abrangente sobre o país, com dados sobre as seguintes doenças: tuberculose, câncer, tracoma, bócio, febre ondulante (zoonose), lepra, encefalite epidêmica, sarampo, febre das montanhas rochosas, difteria e paludismo. Destacou-se a redução da malária nos EUA, observando-se, contudo, que a doença permanecia como um dos mais graves problemas higiênicos em certos pontos do país. Outros temas mencionados foram varíola, peste, notificação de doenças transmissíveis, administração de higiene, inundações do rio Mississipi, toxicomania, leite, proteção às mães e filhos e higiene industrial.

Proposição importante apresentada pela delegação do Uruguai referia-se à obrigatoriedade de vacinação contra varíola. No texto do Código Sanitário, havia a opção pela quarentena, o que era contestado pelos delegados daquele país. Segundo a proposta enfatizada no documento, tratava-se de compatibilizar os preceitos do Código Sanitário com a Convenção de Paris.

No que se refere às doenças venéreas, ocorreu debate sobre as medidas mais adequadas para coibir os efeitos negativos da prática da prostituição. 0 delegado do Panamá defendeu o controle médico e John Long, representante norte-americano, simplesmente a proibição, exemplificando com o que ocorrera no Chile. Em sua perspectiva, a prostituição clandestina geraria menos problemas, uma vez que reduziria o número de parceiros 
sexuais. Note-se que esse debate foi também muito intenso no Brasil com predomínio da tese do controle sanitário e orientação médica (Carrara, 1996).

Durante a VIII Conferência, em que se discutiram prioritariamente assuntos concernentes ao Código Sanitário Internacional, o tema que provocou mais controvérsias, a julgar pelas atas publicadas no Boletim, foi a recomendação da unificação da autoridade sanitária nacional nos países, seja pela criação de um Ministério da Saúde, seja pela criação de um Departamento Nacional de Saúde. Durante o debate, houve clara manifestação. contrária dos delegados argentinos.

A delegação do Peru apresentou documento sobre a criação de Ministérios da Higiene, denominado As bases em que se apóia a criação do Ministério da Higiene, propondo que a VIII Conferência Sanitária PanAmericana reiterasse sua adesão à reforma do Estado, com ênfase na criação de ministérios consagrados aos assuntos médico-sanitários ou departamentos nacionais que centralizassem os serviços sanitários. Como observa Paz Soldan (Bosp, ano 7, n. 1, jan. 1928, p. 146):

Creio que a medicina social, no atual momento, deve ser aplicada com critério político e que cabe aos higienistas reivindicar para si o direito de governar e dirigir as coisas relacionadas com a saúde pública senão (...) contrárias ao bem e ao progresso sanitário da coletividade. Um Ministério de Higiene para os Higienistas. Aqui está minha conviç̧ão. (grifo meu)

A presença e a ênfase nesse tema têm importância especial, pois coloca a reforma do Estado, a reforma sanitária preconizada à época, como uma preocupação importante no debate sobre a adoção de políticas comuns pelos países americanos. No Brasil, como vimos, desde meados da década de 1910, isto estava colocado - a proposta de centralização dos serviços e ações de saúde, preferencialmente com a criação de um ministério. De que forma o tema estava sendo articulado por outros países da América, sobretudo da América do Sul, é matéria que merece atenção. No Peru, por exemplo, ocorreu mobilização social semelhante ao movimento sanitarista brasileiro - o movimento de Riforma Médica. Seu principal líder, Paz Soldan, 
publicou inclusive artigo na revista Saúde, periódico oficial da Liga PróSaneamento do Brasil, que encerrava com a frase: "Eugenizar é sanear"17 (Lima \& Britto, 1996). Importa observar que o médico peruano atuou também durante longo período na OPAs (no Peru) - aproximadamente cinqüenta anos.

Após a VIII Conferência, intensificou-se o processo de ratificação do Código, o que possivelmente foi favorecido pelas missões de reconhecimento realizadas a vários países, inclusive ao Brasil, por John Long, primeiro e mais importante "comissário itinerante" da Opas. ${ }^{18}$ No Boletim PanAmericano de Saúde (ano 8, n.11, nov. 1929), aparece a notícia de que 0 Brasil ratificara o Código em sessão do Congresso de 13/8, publicada no Diário Oficial em 15 de agosto de 1929. Neste mesmo número, é publicado o Código Sanitário em português (Cf. página seguinte).

A VI Conferência havia instituído o Conselho Diretor da Oficina Sanitária Pan-Americana, que se tornou mais efetivo após a aprovação do Código Sanitário. Em reunião dessa instância deliberativa, realizada em 1929, foi outorgado um voto de aplauso às autoridades sanitárias brasileiras pelos esforços empreendidos no combate à febre amarela (Bosp, ano 8, n.11, nov. 1929). Além das doenças transmissíveis, o câncer e problemas de nutrição passaram a figurar na pauta das reuniões que se seguem à VIII Conferência.

Em 1934, a IX Conferência teve início com homenagem póstuma a Carlos Chagas. Hugh Cumming lastimou também as mortes de João Pedro de Albuquerque, do Brasil, e Mario Lebredo, de Cuba - membros do Conselho Diretor da OPAS. A delegação do Brasil, formada por Servulo de Lima e Orlando

\footnotetext{
${ }^{17}$ A respeito das diferentes correntes eugenistas e de suas especificidades na América Latina, ver o trabalho de Nancy Stepan (1991)

${ }^{18} 0$ Boletim, ano 8, n. 11, relata a visita de Long a diversos países da América Latina na condição de representante viajero. As informações mostram que, no Uruguai, o Código Sanitário havia sido ratificado pelo Congresso; no Paraguaj, estava em processo de discussão. 0 informe sobre o Chile dá conta de melhoria nas condições sanitárias: boa água potável, leite pasteurizado etc. No caso da Bolívia, refere-se à ratificação do Código, pouco tempo depois de sua visita. No Brasil, chegou a 7 de setembro de 1928 , fazendo contato com o Dr. Barros Barreto e o Dr. Mattos, destacando, em seu relato, as medidas de controle da febre amarela e da peste.
} 


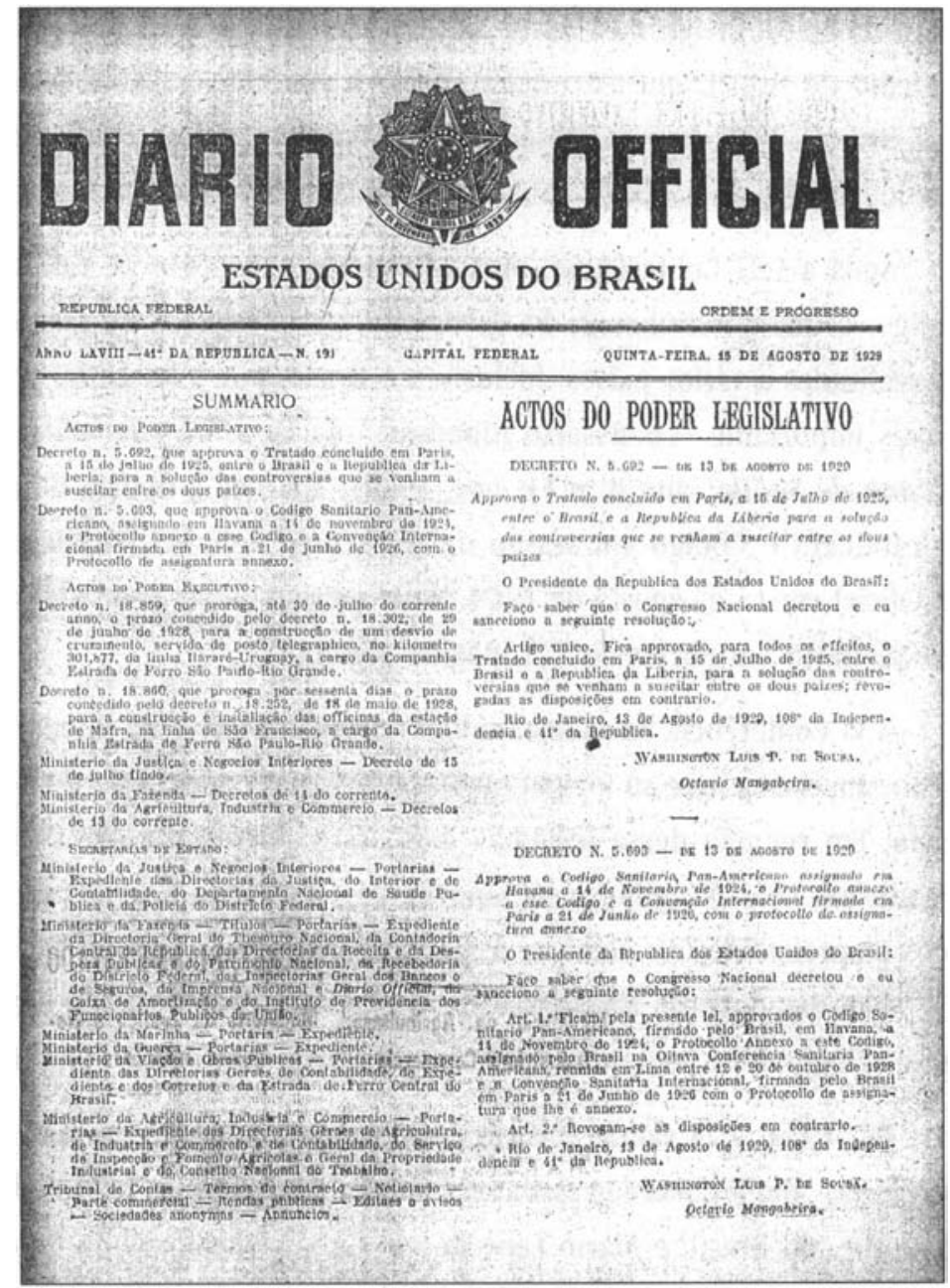

Roças, não se pronunciou na seção de informes gerais, pois o que levavam à Conferência referia-se à profilaxia da febre amarela e da varíola e deixaram então para fazê-lo na respectiva comissão.

o Brasil esteve também em exposição no relato de Fred Soper, que havia solicitado autorização para participar como observador, representando a Fundação Rockefeller Em seção secreta apresentou os resultados de 
seu trabalho no país. Na Ata da IX Conferência Pan-Americana de Saúde, há dois momentos de seu relato que merecem ser transcritos:

Quando em 1927, se reuniu a VIII Conferência Sanitária Pan-Americana em Lima, sabíamos que a febre amarela existia na região costeira do Brasil, acreditando-se estar ausente no resto da América do Sul. Desgraçadamente, logo desmentiu tal crença o inesperado surto do Rio de Janeiro em 1928 e igualmente a imprevista epidemia de 1929 em Socorro, Colômbia. (p. 77) o Brasil tem reconbecido a febre amarela como um problema nacional, porém à luz de nossos atuais conbecimentos deve ser considerada como um problema continental. (p. 107) (grifo meu)

Outro tema importante apresentado à IX Conferência pela delegação brasileira consistiu em tese sobre a univacinação contra a varíola, partindo-se da tese segundo a qual a imunização pela primeira vacina era definitiva: "Que se sugere aos países americanos a conveniência de adotar na profilaxia da varíola a prática de uma só vacinação, de acordo com os resultados conclusivos da experiência brasileira" (Ata da IX Conferência, p. 204).

Houve controvérsia em relação à tese com contrapropostas apresentadas por delegados de outros países, principalmente pelo sanitarista peruano Carlos Henrique Paz Soldan. No debate, afirmavam os delegados brasileiros a tendência conservadora da saúde pública, que seria dominada pela tradição e pela rotina. Por fim, os delegados aprovaram a seguinte deliberação:

A IX Conferência Sanitária Pan-Americana tem tomado conhecimento da comunicação apresentada a seu exame pela delegação do Brasil, pela qual recomenda a prática da univacinação antivariólica e concorda submetê-la ao estudo das autoridades sanitárias dos países da América, insistindo na conveniência de investigar os resultados da estatística de revacinação. (Ata da IX Conferência, p. 269)

Durante o evento, apresentaram-se informes e aprovaram-se resoluções sobre as seguintes doenças: febre amarela, variola, alastrim (apresentada pelo Dr. Roças a tese de sua autonomia como entidade mórbida), lepra (com destaque para a recomendação de que se proibisse o casamento 
de doentes com pessoas sãs), doenças venéreas, peste (com voto de louvor à OPAS e ao Dr. Long) e brucelose. Outro tema importante foi a profilaxia da tuberculose, aprovando-se a seguinte resolução quanto à BCG: "a IX Conferência Sanitária Pan-Americana, tendo em vista a escassa experiência sobre vacinação BCG na maioria dos países da América, resolve esperar novas observações e tratar o assunto na próxima Conferência Sanitária Pan-Americana" (Ata da IX Conferência, p. 419).

Nas décadas de 1930 e 1940, o Brasil progressivamente ocupa posição de mais destaque na OPAs, o que culminou com a escolha de João de Barros Barreto, diretor do Departamento Nacional de Saúde Pública, para Vice-Diretor na X Conferência, realizada em Bogotá, em 1938.

Essa afirmação pode ser aferida inclusive pelo expressivo número de artigos por ele publicados no Boletim e pelo destaque atribuído a suas intervenções nas instâncias de deliberação da OPAs. Durante a $4 \underline{1}$ Conferência Pan-Americana de Diretores Nacionais de Saúde, Barros Barreto, destacou o problema representado pela navegação aérea, indicando a necessidade de modificar alguns aspectos do texto da Convenção Sanitária Internacional. Manifestou também a preocupação do governo brasileiro com o tema da nutrição. 0 Brasil também se destacava em outros temas de menor expressão na agenda tradicional de saúde pública, como o da higiene mental, sendo apontado como um dos primeiros países na América Latina a criar o Curso de Psiquiatria e o primeiro, em todo o continente americano, a fundar uma sociedade nessa área: a Sociedade Brasileira de Psiquiatria, Neurologia e Medicina Legal, fundada em 1907 (BosP, ano 20, n.10, out. 1941).

As doenças transmissíveis continuavam, entretanto, a ser o destaque nas notícias sobre o Brasil, que oscilavam entre manifestações de júbilo, como, por exemplo, na manifestação oficial da OpAs diante do sucesso da campanha de erradicação do mosquito Anopheles gambiae, e o registro de surtos epidêmicos de outras doenças, como a epidemia de poiliomielite em 1939, no Rio de Janeiro, uma das mais severas registradas no Brasil (BosP, ano 20, n.10, out. 1941). 


\section{EDITORIALES}

UNA GRAN PROEZA DE LA SANIDAD BRASILENA: LA VICTORIA CONTRA EL ANOFELES

Hecho destacado en la IV Conferencia Panamericana de Directores Nacionales de Sanidad ${ }^{1}$ fué la afirmación del Dr. João de Barros Barreto, de que ya para abril 1940 el $A$. gambiae habfa sido erradicado de algunas zonas del Brasil, y que el éxito logrado con los métodos empleados permitía esperar la desaparición de dicho mosquito de todo el territorio brasileño. Como era de esperar, la Conferencia tomó debida nota de punto tan importante con un voto en que felicitaba a la República del Brasil por el éxito aleanzado en esa campaña, por considerarla de la mayor utilidad para proteger la salud de todas las Repúblicas de América. Los últimos informes publicados, tanto en la prensa médica brasileña como en la memoria anual de 1940 de la Fundación Rockefeller, ponen una vez más de manifiesto la enormidad del problema planteado por el paludismo epidémico en una vasta región del Hemisferio Occidental, y el gran triunfo que representa la erradicación del vector, vista la amenaza que entrañaba para todos los paises del Continente en estos días de rápidas comunicaciones.

Vector por excelencia del mal en $A$ frica, ${ }^{2}$ el A. gambiae o costalis es un mosquito altamente domesticado, pues ha sido eneontrado únicamente dentro de las casas a todas horas del dia, y cría en los depbsitos de aguas cercanos. Buena idea del peligro que entraña su presencia la ofrece su coeficiente de infección de $60 \%$, comparado con 0.4 a $0.5 \%$ para otros vectores del paludismo, y la proporeión de casos graves, que se traduce en una letalidad de 6-15\%.3

La presencia del nuevo vector en el Continente Americano fué descubierta por primera vez en Río Grande, en marzo 1930, por el Dr. Shannon," mientras realizaba investigaciones para el Servicio de Fiebre Amarilla en la costa del norte del Brasil.s El primer foco, casi

1 "Cuarta Conferencia Panamericana do Direetoren Nacionales de Sanidad: Resumen de aus labores," p. 8; Pub. Na. 162 de la OA. San. Pan., mayo 1941. (No era la primera ves que se diseutha el problema en las Confereneina Panamerioansa do Sanidad, pues ya habls sido objeto de mucha atención en ls IX Conferencia Banitaria Panamericana, donde lo trat6 el Dr. Soper, $y$ en la X, en que lo diseutieros los Dreo Pinotti y Boper.)

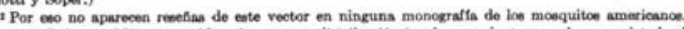
Ninguno de loe anofelinos conocidos alcanza una dietribueión igual o nemejanto que abarta caei toda el Alrica o ialas cercanas, Grecia en Europa, y por fin Amtricen.

El pambiar tambien trasmito la flariasis de Baneroft.

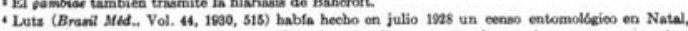
sin encontrarlo, y tambies llams la ateneion sobre el peligro presentado por las nuevas comunioacioses ríplase con Africa

- El moequito fué probablemeato introducido en 1928, ereyendo Souna-Pinto que debis llegar en forma adulta, comenasado las hembras inmedintamente la ovipoeicion.

1177

Editorial sobre a campanha contra o Anpopheles gambiae no Brasil.

Fonte: Bosp, 1941.

A preocupação em veicular, no Boletim da Oficina Sanitária PanAmericana, informações do governo brasileiro, no campo da saúde, esteve presente desde 1926, quando Clementino Fraga era o Diretor do Departamento Nacional de Saúde Pública, e se passou a publicar o 'Noticiário brasileiro'. Após a revolução de 1930, com a criação do Ministério de Educação e Saúde, $a$ atenção com a imagem pública relacionada às políticas sociais e, especifica- 
mente às de saúde pública, se acentuaria particularmente no período autoritário do Estado Novo (1937-1945). 0 ministro Gustavo Capanema e, na implementação dos assuntos de saúde, João de Barros Barreto desenvolveram intensa atividade de divulgação não apenas de sucessos no combate a doenças transmissiveis, mas de reorientações na administração pública, com ênfase em racionalidade, extensão territorial e constituição de sólida burocracia.

É a partir desse enquadramento, aliado à atmosfera da Segunda Guerra Mundial, que pode ser melhor avaliado o impacto da realização da XI Conferência Sanitária Pan-Americana, no Rio de Janeiro, em 1942. No plano interno, um ano antes, durante as comemorações do aniversário do Estado Novo, o ministro Capanema promovera a I Conferência Nacional de Saúde, dando início, em um período ditatorial, ao estabelecimento de fórum de especial significado para a constituição da política nacional de saúde (Hochman \& Fonseca, 2000).

A XI Conferência Pan-Americana de Saúde teve início na data comemorativa da Independência do Brasil. Em sua comissão organizadora, contou com Barros Barreto (presidente), Raul Godinho (secretário geral executivo) e, na posição de vogais, com Mário Pinoti, Carlos Sá, Décio Parreiras e Humberto Pascali. Entre seus relatores, figuravam também nomes expressivos do sanitarismo e da ciência nacionais: Adelmo Mendonça, Carlos Chagas Filho, Eder Jansen de Mello, Francisco Borges Vieira, Francisco de Magalhães Neto, Genésio-Pacheco, Geraldo Paula Souza, Guilherme Lacorte, Henrique Aragão, Otavio de Magalhães, Paulo Parreira Horta e Samuel Pessoa.

Outro evento importante, paralelo à Conferência, foi a Exposição PanAmericana de Higiene, em que se destacavam as realizações do Brasil no combate às doenças transmissíveis, notadamente a febre amarela e a malária.

o conflito mundial, e como corolário a defesa continental e da saúde, figurou como primeiro e mais importante tema abordado, inclusive com a indicação de realização de inquérito sobre a distribuição geográfica das doenças transmissíveis de importância em tempo de guerra. Sugeriu-se também a coope- 
ração integral entre os serviços de saúde, militares e civis (Ata Final da XI Conferência, Bosp, ano 22, n. 3, mar. 1943). Ademais, a primeira metade do século XX, e aí não reside naturalmente nenhum paradoxo, viu nascer as formas modernas de cooperação internacional e também a generalização da guerra como fenômeno mundial. $\mathrm{Na}$ perspectiva do pensamento sanitarista da época, poucos discursos são tão expressivos como o de Fred Soper (1943: 321):

Provavelmente o maior obstáculo à erradicação de enfermidades transmitidas por artrópodes é a guerra. Em tempos de paz, o trânsito global, especialmente o aéreo, é uma constante ameaça para esses programas, porém resulta de menor importância comparado às operações militares em grande escala. Certamente não existe mais dura prova para as técnicas de medicina preventiva do que a apresentada pelas condições de prolongada campanha militar e suas inevitáveis sequielas. Quando, aos riscos normais e inevitáveis de doença que representa o conflito armado, se acrescenta o espectro funesto da guerra biológica deliberada (que pode incluir a disseminação de enfermidades propagadas por artrópodos) se faz evidente a possibilidade que se coíba a erradicação destas infecções. Na ausência de conflitos mundiais e sobretudo aqueles em que os fins parecem justificar medidas extremas, tais como a guerra biológica, existe toda razão para pensar que a incidência das enfermidades transmitidas por artrópodos continuará em descenso. Nenhuma delas haveria de ameaçar novamente a civilização.

$\mathrm{Na}$ abordagem das doenças transmissíveis, a XI Conferência aprovou resolução que apresentava a malária como "a doença que maiores prejuízos causa a maioria das nações do continente" e recomendava que os departamentos nacionais de saúde dos países americanos aceitassem as recomendações da Comissão de Malária da Oficina Sanitária Pan-Americana e a considerassem como seú órgão consultivo. Observe-se que, nos Boletins relativos à década de 1940 , em vários momentos, acentuava-se a malária como grave problema sanitário do continente e, mesmo no início dos anos 1920, anteriormente à manifestação da epidemia motivada pelo Anopheles gambiae, o Boletim apresentava, na primeira página, mensagem de advertência sobre a necessidade de combater essa enfermidade. 
As ações destinadas à erradicação do Aedes aegypti no Brasil, Peru e Bolívia resultaram em voto de aplauso, e, mais uma vez, a febre amarela constituiu tema prioritário do debate entre as autoridades sanitárias do continente americano. Outras doenças transmissíveis, como a doença de Chagas, a influenza, a lepra, a peste, o tifo e a tuberculose, também foram objeto de teses e resoluções. No que diz respeito à tuberculose, deliberação importante consistiu na recomendação do método de diagnóstico criado pelo médico brasileiro Manoel de Abreu.

Questões de engenharia sanitária, mormente uso do cloro na higienização da água e produção do verde Paris na luta contra o mosquito, indicam a crescente importância que esse campo de especialidade vinha adquirindo. A maior ênfase em tópicos como nutrição e habitação consiste também em importante característica da XI Conferência. Em seu término, elegeu-se o novo conselho diretivo, com a seguinte composição: presidente de honra, João de Barros Barreto; diretor, Hugh Cumming (EUA); vice-diretor, Jorge Brejano (Colômbia); primeiro conselheiro, Victor Sutter (El Salvador); segundo conselheiro, Enrique Claveaux (Uruguai); secretário executivo, Aristides Moll; vocais: representantes nomeados pelos seguintes países: Paraguai, Haiti, Honduras, Bolívia, República Dominicana e Panamá.

A conferência que antecedeu a criação da OMS - e o novo desenho da cooperação internacional do setor - apresentou em suas resoluções alguns indícios do alargamento da pauta e de uma cooperação técnica que, embora ainda frágil, indicava o papel mais ativo que a OpAs viria a desempenhar no período seguinte, após a eleição de Fred Soper, em 1947.19

Esse período, que se delimitou como o primeiro da relação entre 0 Brasil e a OpAs, teve suas principais finalidades oficiais bem sumarizadas por Hugh Cumming, que a dirigiu de 1920 a 1947:

\footnotetext{
${ }^{19}$ A eleição de Soper ocorreu durante a XII Conferência que, devido à Segunda Guerra, só pôde se realizar em 1947.
} 
1- Prevenir, por meio de medidas cooperativas, a propagação de enfermidades provenientes de outros países e de uma República Americana a outra. Este propósito compreende impedir a introdução de vetores de doenças, inclusive aquelas ainda não muito disseminadas, tais como a doença do sono (tripanossomíase africana), febre maculosa das Montanhas Rochosas, tripanossomíase americana, oncocercose, vetores conhecidos da febre amarela e outros menos conhecidos.

2- Evitar a necessidade de pôr em vigor custosas medidas de quarentena com respeito a portos infectados, tomando as devidas precauções a fim de impedir a infecção de transmissores comuns por mar, por terra e por ar.

3- Estimular as autoridades sanitárias em todas as Repúblicas Americanas a realizar maiores esforços para combater e eliminar as doenças transmissíveis.

4- Obter conhecimento imediato das doenças passíveis de quarentena no território das Repúblicas Americanas e obter também informes análogos dos países do Hemisfério Oriental por intermédio de outras entidades internacionais, especialmente a Oficina Internacional de Higiene Pública de Paris.

5- Fomentar relações cordiais entre os povos americanos. (Ata da IX Conferência Sanitária Pan-Americana)

Na mesma apresentação, Cumming revelou um certo 'otimismo', diante das possibilidades de controle das doenças transmissíveis:

É difícil dar-se conta hoje que, durante a última parte do século XIX, reinavam epidemias de enfermidade como febre tifóide, varíola, cólera, febre amarela e que, no Oriente, a peste bubônica era comum; que até uma época tão próxima como o fim desse século, com poucas exceções, as medidas de quarentena, severas e custosas, constituíam o único método com que as autoridades sanitárias se esforçavam para combater as enfermidades, especialmente peste, cólera e febre amarela. (Ata da IX Conferência Sanitária Pan-Americana)

0 papel efetivo da organização e seu impacto nas políticas de saúde dos países que a integravam era certamente reduzido, e as resolu- 
ções aprovadas nas diferentes instâncias e mesmo nas Conferências Sanitárias Pan-Americanas seriam mais bem definidas como recomendações, cuja aplicação dependia de processo intenso de trabalho e convencimento das autoridades sanitárias dos países. No próprio debate sobre a implementação do Código Sanitário, durante a VIII Conferência, o ponto foi bem observado por John Long, que afirmou não ter a Oficina "poder coercitivo algum", não podendo exercer qualquer controle para seu cumprimento por cada país.

As ações de cooperação técnica, embora bastante incipientes, basicamente restringindo-se à atividade do representante itinerante, começavam a apresentar alguns programas de maior impacto, entre os quais se destacavam a criação do Instituto de Nutrição do Centro América e Panamá, em 1946, e o programa de bolsas de estudos, com início oficial em julho de 1939. Esse programa de bolsas incluía as seguintes modalidades: saúde pública - concedidas pelo diretor geral do Serviço de Saúde Pública dos Estados Unidos da América, após recomendação do diretor da Opas -; medicina - por convênios estabelecidos entre a Opas e o coordenador de relações comerciais e culturais dos EUA -, e residência médica - concedida por hospitais norte-americanos.

Observa-se, a final do período em análise, a presença mais marcante do Brasil na OpAs. Tal constatação está fundamentada em evidências, como a liderança continental que passou a exercer Barros Barreto, a maior presença do país no debate científico durante as conferências sanitárias e a visibilidade internacional das atividades de combate à febre amarela e à malária, realizadas em larga medida com base em cooperação entre o governo brasileiro e a Fundação Rockefeller.

No plano da formação de pautas de temas e consensos básicos sobre questões de saúde, o Boletim representou também uma das mais importantes atividades. Tendo seu primeiro número publicado em 1922, consistiu em importante meio de formação de opinião entre médicos e gestores de 
saúde pública. ${ }^{20}$ Nesse periódico, há um número expressivo de artigos publicados por brasileiros e de seções que existiram, por considerável tempo, como a 'Seção Portuguesa' com notas e registros produzidos sobre a situação sanitária do país e dos estados da Federação, e que, em fins da década de 1930, seria substituída pelo 'Noticiário Brasileiro'.

João de Barros Barreto foi o sanitarista brasileiro que mais publicou artigos nessa primeira fase da organização. Além da febre amarela, outro tema muito presente nos artigos relacionados ao Brasil foi a reforma administrativa na área da saúde promovida durante o Governo Vargas.

Da criação da OpAs até o término da gestão de Hugh Cumming, mudanças importantes ocorreram no Brasil, relacionadas, de modos diversos, à nova configuração mundial que vai se delineando nas décadas de $1930 \mathrm{e}$ 1940. Ao final desse período, encerrava-se também o regime autoritário do Estado Novo, que trouxe profundas implicações para a economia e a sociedade brasileiras. Na área de saúde, consolidava-se um novo tipo de sanitarismo, cujas lideranças receberam forte influência das agências norteamericanas que cooperavam com o governo brasileiro no campo da saúde. Esse fato, como foi apenas parcialmente apontado, teria expressivo impacto nas relações entre o Brasil e a OPAs.

\section{O Brasil e a nova fase da Organização Pan-Americana da Saúde (1947-1958)}

As relações entre o Brasil e a Opas, no período de 1947 a 1958, devem ser entendidas tomando-se em consideração dois fatores fundamentais: de um lado, a decisão dos Estados Unidos da América do Norte em

\footnotetext{
${ }^{20}$ Miguel Bustamente, em retrospectiva histórica sobre os cinqüenta primeirós anos da OPAs, apresenta dados sobre a tiragem e circulação desse importante periódico, que publicava artigos em espanhol, português, inglês e francês, e era distribuído gratuitamente a médicos e a outras pessoas relacionadas com os departamentos de Higiene Nacionais e locais.
} 
estabelecer acordos bilaterais entre o Instituto de Assuntos Interamericanos, criado em 1942 e subordinado ao Departamento de Estado, e os governos latino-americanos, e, de outro, a criação da Organização Mundial da Saúde, em 1946. Ambos os fatos, relacionados à conjuntura que se inaugura com a Segunda Guerra, indicam a importância estratégica atribuída à saúde na nova ordem mundial e continental que se configurava.

\section{A saúde como questão estratégica nas relações entre Brasil e Estados Unidos}

No Brasil, o período da Segunda Guerra implicou notável alteração nas relações internacionais com a progressiva aproximação aos Estados Unidos da América do Norte, gerando mudança na posição de neutralidade e na característica da política externa que Gerson Moura (1980) definiu como "autonomia na dependência". Pouco se tem analisado, entretanto, o papel das ações relativas à saúde naquele contexto. 0 estudo de André Campos (2000) vem preencher essa lacuna, contribuindo tanto para que se considere o cenário da política externa, dimensão pouco presente nos estudos históricos sobre saúde, como, principalmente, para o reconhecimento da importância estratégica de questões sanitárias nas relações internacionais.

Esse novo contexto afetaria a posição da Opas de diferentes maneiras. A sustentação financeira das políticas do organismo pelo governo norteamericano passou por alguns revezes que se explicam pelo maior interesse em atuação mais direta nos países, em detrimento da aposta no fortalecimento de um organismo baseado em relações intergovernamentais. Isso ocorreu mesmo considerando o total apoio do governo norte-americano à eleição de Fred Soper.

o fato é que, nas décadas de 1930 e 1940, foram adotadas várias políticas de apoio aos países da América Latina; entre elas, a criação de 
programas de bolsas de estudo, mediante convênio, firmado pelo Escritório para a Coordenação das Relações Culturais e Comerciais entre as repúblicas americanas e a OpAs. Durante a Segunda Guerra Mundial, os Estados Unidos contribuíram significativamente com a OPAs, apoiando programas especiais e bolsas de estudo. Após seu término, pretendiam suspender a alocação de pessoal e reduzir os recursos para o programa de bolsas.

Do ponto de vista do governo norte-americano, não se tratava de desinteresse pelo investimento em países latino-americanos, mas de uma nova estratégia que privilegiava a criação, nesses países, de instituições locais orientadas pela política norte-americana. Naturalmente, os interesses em pauta eram bastante complexos e incluíam também os dos países latinoamericanos mobilizados para atrair grandes investimentos industriais, como foi o caso do Brasil.

Motivações de grupos profissionais deveriam também ser consideradas para que se pudesse empreender análise mais abrangente sobre o tema, o que escapa aos propósitos deste trabalho. 0 importante é ter em mente que os interesses em jogo $\mathrm{e}$ as idéias defendidas não implicavam posições fixas e definidas a priori. Um exemplo disso é a atuação de Fred Soper: em alguns momentos articulador de propostas do governo norteamericano, em outros, aliado aos sanitaristas e governos latino-americanos na busca de sustentação para a OpAs e para os programas de combate a doenças que considerava prioritárias.

Sob o impacto do ataque japonês a Pearl Harbour, realizou-se no Rio de Janeiro, em janeiro de 1942, a III Conferência de Ministros das Relações Exteriores das Repúblicas Americanas. No evento, recomendou-se principalmente a mobilização de recursos dos países latino-americanos, tendo em vista a guerra e a adoção de medidas de saúde pública mediante acordos bilaterais. Da Conferência, resultaram os acordos de Washington, entre os quais o de saúde e saneamento que daria origem ao Serviço Especial de Saúde Pública (Campos, 2000; Braga, 1984). 
Em documento redigido pelo então ministro da Educação e Saúde, pode-se constatar que, durante a Conferência, "nos bastidores, as negociações para a organização de um serviço de saúde brasileiro-americano foram encaminhadas num encontro entre Fred Soper, diretor da Fundação Rockefeller no Brasil, e Gustavo Capanema" (Campos, 2000: 201). ${ }^{21}$

Na primeira seção deste trabalho, ressaltou-se a importância da cooperação com organismos norte-americanos, em particular a Fundação Rockefeller, na formação de novas gerações de sanitaristas a partir da década de 1920. No caso do SESP, a vinculação com políticas do governo norteamericano ocorreria até a década de 1960, quando não mais foi renovado o acordo com o Instituto Interamericano. Esse organismo, apesar de administrativamente subordinado ao Ministério da Educação e Saúde até 1953, e, a partir daí, ao recém-criado Ministério da Saúde, atuou com relativa autonomia, dispondo de plano de carreira próprio e estabelecendo acordos bilaterais com os governos estaduais. ${ }^{22}$

A criação e a atuação do Sesp durante seus primeiros vinte anos não se deram sem que se explicitassem divergências por parte de sanitaristas brasileiros. Em um primeiro momento, Barros Barreto expressaria críticas agudas à decisão do governo brasileiro, provavelmente motivado pela independência do SESP em relação ao Departamento Nacional de Saúde. Na década de 1950, Mario Magalhães seria o principal opositor das políticas 'sespianas' que, em sua perspectiva, não consideravam adequadamente as relações entre condições sociais e sanitárias, reduzindo a saúde a uma questão puramente técnica (Campos, 2000; Fonseca, 2001).

\footnotetext{
${ }^{2 !}$ Essa informação consta do artigo já citado de André Campos e encontra-se em manuscrito redigido por Capanema (Arquivo Gustavo Capanema - CPDOC - Fundação Getúlio Vargas, s.d.).

${ }^{22}$ O SEsp transformou-se em 1960, após o encerramento do convênio com o governo norte-americano, em Fundação Serviço Especial de Saúde Pública (Fsesp). Em 1991, a Fsesp foi extinta e seus quadros incorporados à Superintendência de Campanhas, integrando a Fundação Nacional de Saúde (FunasA). Sobre a história do organismo, ver também Campos (1997) e Fonseca (1989).
} 
Concebido originalmente para promover o saneamento em regiões como a Amazônia, onde se previa a exploração comercial da borracha, e o vale do rio Doce, destinado à extração de riquezas minerais, o SESP, posteriormente, teria como atividade principal a implementação de um modelo baseado no estabelecimento de redes integradas de unidades de saúde, valorizando a cooperação com os governos estaduais, o que contrastava com 0 modelo verticalizado das campanhas de saúde pública (Campos, 2000). Como ocorrera com outras políticas implementadas no Brasil, o modelo norte-americano, fundamentado na idéia de medicina preventiva, sofreria alterações locais, que ficam bastante claras no relato de dois 'sespianos', Ernani Braga e Marcolino Candau. Ambos viriam a ter posição significativa na OPAS, sendo Candau o segundo diretor da OMS, cargo que ocupou de 1953 a 1973. Destaca-se o seguinte trecho:

No Brasil, especialmente nos últimos anos, observou-se, sob o controle do governo, o desenvolvimento de um extenso programa de assistência médico-social compulsório para as classes assalariadas, programa esse que, apesar de vir atender a uma razoável parte de nossa população, não pode ainda cogitar da grande massa constituída pelos habitantes da zona rural, os quais por não trabalharem em regime regular de emprego, não sendo portanto obrigados a contribuir para as organizações de seguro médico-social, vêem-se, em sua maioria, totalmente desprovidos de qualquer tipo de assistência médico-sanitária, a não ser, aqui e ali e assim mesmo muito mal, aquela que é prestada pelos serviços oficiais de saúde e pelas instituições de caridade. (Candau \& Braga, 1984: 59) ${ }^{23}$

Se a Fundação Rockefeller vem merecendo crescente atenção de historiadores e cientistas sociais pela intensa atividade no país durante as décadas de 1920 a $1950,{ }^{24}$ o SeSp tem sido menos estudado. Um aspecto

${ }_{23}^{23} 0$ artigo fora originalmente publicado na Revista da Fundação Especial de Saúde Pública, 2 (2), dez.1948.

${ }^{24}$ No caso do Brasil, ver os trabalhos de Castro Santos (1987, 1989); Benchimol (2001); Faria (1994); Marinho (2001). Na América Latina, ver principalmente os trabalhos de Cueto (1996b). 
importante consiste no fato de sua administração ter se organizado, contando com o que se considerava "máquina extraordinariamente bem azeitada", 25 montada pelo governo brasileiro e pela Fundação Rockefeller na campanha contra o Anopheles gambiae, realizada em 1937, no Nordeste.

Respeitadas as diferenças, ambas organizações empreenderam programas que mobilizaram muitos recursos financeiros e humanos, com sensível impacto na formação de gerações de sanitaristas, fato que torna por vezes mais difícil avaliar a importância da cooperação intergovernamental e interamericana sob liderança da OpAs. Certamente, o melhor caminho não é estabelecer comparação entre esses organismos, de natureza diversa, mas situar o tema da cooperação interamericana em uma moldura mais ampla que permita considerar, no plano macro-sociológico, as mudanças na posição do governo norte-americano e suas implicações para a OPAS, e, no plano micro-sociológico, a formação e trajetória de atores sociais com papel destacado em todos esses organismos e na história da saúde no Brasil.

No que se refere às relações interamericanas, uma importante característica do período foi a mudança do padrão de relacionamento que, desde $o$ início, marcara as atividades da Oficina Sanitária Pan-Americana: sua subordinação à política de saúde do governo norte-americano. É possível indicar uma fase de transição que, posteriormente, implicaria maior presença dos países latino-americanos na gestão da OPAS, o que se expressou na eleição do chileno Abrahan Horwitz para o cargo de diretor geral em 1958.

Para a análise, ainda que breve, da gestão de Fred Soper como diretor da Opas, é necessário considerar essa dimensão e, também, um segundo fato, este mais destacado nos balanços históricos: a criação da OMS em 1946.

\footnotetext{
${ }^{25}$ A expressão foi utilizada por Marcolino Candau. Ver Ernani Braga (1984).
} 


\section{Brasil e a criação da Organização Mundial da Saúde}

A presença do Brasil na criação da OMS tem sido mencionada tanto nos trabalhos retrospectivos sobre esse organismo como naqueles que vêm se detendo na história da OpAs. Ressalta-se o fato de o médico paulista, Geraldo Paula Souza, ter apresentado a proposta de criação de uma nova entidade para a saúde mundial. Merece registro a participação de Paula Souza no grupo de sanitaristas brasileiros que, na década de 1940, estava recriando a Sociedade Brasileira de Higiene, muitos com atuação no SESP, entre eles Marcolino Candau e Maneco Ferreira.

Com a instauração do VII Congresso Brasileiro de Higiene, realizado em 1947, e presidido por Marcolino Candau, retomam-se as atividades da antiga Sociedade Brasileira de Higiene, criada em $1923 .{ }^{26} 0$ colóquio realizou-se em São Paulo, na Faculdade de Higiene e Saúde Pública, dirigida por Geraldo de Paula Souza, e pautou-se pela defesa de uma atuação em âmbito nacional que conferisse a esse grupo protagonismo semelhante ao que alcançara o movimento sanitarista da Primeira República.

Em 1945, durante a Conferência de São Francisco, nos Estados Unidos, realizada com o objetivo de aprovar projeto de Constituição da Organização das Nações Unidas, Paula Souza teria verificado a falta de referências a questões de higiene e saúde. Isso motivou a apresentação de proposta, juntamente com a delegação da China, de se constituir um comitê responsável por avaliar as possibilidades de se criar uma organização internacional de saúde.

No ano seguinte, o Conselho Econômico e Social das Nações Unidas reuniu-se para convocar Comissão Técnica Preparatória da Conferência Sanitária Internacional, cujo fim seria criar uma organização internacional. Esse comitê, reunido em Paris em março-abril de 1946, foi integrado por 16 especialistas em saúde pública e representantes de quatro organizações in-

${ }^{26}$ Para o estudo da primeira fase da Sociedade Brasileira de Higiene, ver Madel Luz (1979). 
ternacionais de saúde. Hugh Cumming e Aristides Moll assistiram ao evento na qualidade de Diretor e Secretário da "Organização Sanitária Pan-Americana", que se converteria no nome oficial da Oficina Sanitária Pan-Americana no ano seguinte.

No mês de julho de 1946, 61 Estados nacionais formaram a Constituição da OMS. 0 documento consta de um preâmbulo de 19 capítulos com 82 artigos, como carta básica da Organização, estabelecendo o objetivo geral e as estruturas central e regional, além de definir sua condição jurídica e estipular relações de cooperação entre as Nações Unidas e outras entidades, tanto governamentais como privadas, que se ocupavam de temas de saúde.

Não foi simples o estabelecimento do papel a ser desempenhado e a garantia de alguma autonomia de ação à Opas. Um fator decisivo foi o aumento de seu orçamento com base na elevação das contribuições dos países latino-americanos, principalmente a Argentina, o Brasil e o México. A capacidade de sustentação da OPAs, em contraste com o exíguo orçamento da OMS, pesou efetivamente na negociação entre as duas entidades. Em julho de 1948, durante a $2^{\mathrm{a}}$ Assembléia Mundial de Saúde, firmou-se acordo entre o diretor geral da OMS, Brock Chisholm e Fred Soper, diretor da OPAS, pelo qual esse organismo, sem perda de sua identidade, converteu-se em oficina Regional para as Américas da OMS (OPAS, 1992; Soper, 1977).

\section{0 período de Fred Soper}

Já mencionei a experiência de Fred Soper no Brasil, onde atuou durante vinte anos nas atividades da Fundação Rockefeller, representando-a, no país, a partir de 1930. Em suas Memórias, evidencia-se a importância desse período em sua trajetória profissional e de como aprendera com as campanhas contra o Aedes aegypti e o Anopheles gambiae, algo que seria crucial para atividades posteriores no continente africano (Soper, 1977). 
Fred Soper estabeleceu forte interação com sanitaristas brasileiros, como Clementino Fraga, Belisário Pena e João de Barros Barreto, e pode-se afirmar que suas atividades, segundo modelo de ampla cobertura territorial e vigilância sanitária estrita, apresentavam afinidades com a centralização da administração pública durante $o$ Governo Vargas.

Uma das questões controversas na gestão da saúde pública brasileira consistia na organização de serviço próprio de combate à febre amarela em São Paulo, a despeito do acordo entre a Fundação Rockefeller e o governo federal prever o controle em todo o território nacional. Em 1938, após entendimentos entre Soper e Getúlio Vargas, o interventor de São Paulo, Ademar de Barros, estabeleceu que as ações de combate à febre amarela ficariam subordinadas à Comissão do Serviço de Febre Amarela. Segundo Soper (1977: 131),

E assim Getúlio Vargas, em 1938, estabeleceu um serviço de febre amarela para todo o Brasil. Repetidamente os que lutaram contra a febre amarela - Oswaldo Cruz, em 1910, Téffilo Torres, em 1918, e Clementino Fraga, em 1929 - tinham falhado em superar a resistência de governos estaduais em se associar à liderança nacional para a solução do problema. Trinta e sete anos depois de Emilio Ribas ter indicado o caminho para a erradicação da febre amarela em São Paulo, o estado passou a integrar um programa nacional.

Em seu diário, inúmeras reminiscências e reprodução de diálogos com políticos e sanitaristas brasileiros reforçariam a impressão da mencionada afinidade eletiva entre certo modelo de ação em saúde pública, notadamente no combate a doenças transmissíveis por vetores, e a centralização política - ponto sem dúvida controverso e que mereceria análise mais aprofundada. De todo modo, cabe ressaltar a importância das relações com o governo federal e os sanitaristas brasileiros e de como isto interferiria no momento posterior quando Fred Soper assumiu a direção geral da Opas.

A eleição de Soper para esse cargo ocorreu na cidade de Caracas, em 1947, durante a XII Conferência Sanitária Pan-Americana, na qual o tema 
da nova organização internacional em matéria de saúde dominou o debate. Nesse fórum, ocorreram mudanças importantes em termos da estrutura e instâncias decisórias e da agenda de questões prioritárias. Desde então, a Conferência Sanitária Pan-Americana, além de traçar diretrizes de política sanitária para o continente americano, passou a atuar como Comitê Regional da Organização Mundial da Saúde, contando com a participação de dirigentes desse organismo. A Oficina Sanitária Pan-Americana transformou-se em Organização Sanitária Pan-Americana, constituída pelos seguintes organismos:

1) a Conferência Sanitária Pan-Americana, corpo diretor supremo, com atribuições de decidir sobre políticas e eleger o diretor, composta de representantes dos governos-membros e reunindo-se a cada quatro anos;

2) o Conselho Diretor, também composto pelos governos-membros, reunindo-se nos anos em que não se realizasse a conferência, e com atribuições similares;

3) o Comitê Executivo, inicialmente composto de sete governos-membros, eleitos pelo Conselho Diretor ou pela Conferência para mandados de três anos em forma alternada, que deveria reunir-se regularmente duas vezes por ano e com funções de acompanhar o trabalho da Secretaria e preparar as reuniões do Conselho ou da Conferência;

4) a Oficina (Repartição) Sanitária Pan-Americana, que deixava de ser uma junta ou conselho para ser a Secretaria Executiva da Organização, sob o comando e responsabilidade do diretor, seguindo as orientações e decisões dos governos por meio da Conferência, do Conselho ou do Comitê Executivo.

É interessante observar a composição dessas instâncias, segundo a deliberação da XII Conferência:

- Conselho Diretivo: reunião anual com representante de cada país.

- Comitê Executivo: Brasil - Heitor Pragues Froes; Costa Rica - Solón Nunez; Cuba - Luiz Espinosa; EUA - Thomas Parran; México - Ignacio Morones Prieto; Uruguai - Enrique Claveaux. 
- Oficina: Hugh Cumming (diretor emérito), Fred Soper (diretor), John Murdock (subdiretor) e Miguel Bustamante (secretário geral).

- Membros de honra: Peru - Carlos Paz Soldán; Guatemala - Luis Gaitas; México - Manuel Martinez Bási; Brasil - João de Barros Barreto; Venezuela - Eugenio Fernandez.

No que se refere à mudança na pauta de temas prioritários, destacam-se a inclusão e o relevo conferido a temas como organização de serviços nacionais de saúde, zoonoses, saúde dos trabalhadores, migrações, alimentos, fármacos e as relações entre a saúde pública e os seguros sociais. A saúde materno-infantil seria objeto da Declaração de Caracas que estabelecia "os direitos da criança a uma vida saudável e à saúde". Outra área que viria a se desenvolver com maior intensidade após a Conferência é a de engenharia sanitária, consistindo o saneamento básico tema central da cooperação técnica efetivada pela OpAs, especialmente a partir da década de 1950. Em 1948, criou-se a Associação Interamericana de Engenharia Sanitária.

No plano das novas relações internacionais, ao lado das bases em que se deveria firmar acordo com a OMS, o outro tema prioritário, a esse intrinsecamente relacionado, foi a sustentação financeira da Organização, diante de um orçamento historicamente reduzido e também, como vimos, das novas relações que se estabeleciam com o governo dos Estados Unidos. Após intenso processo de negociação com os governos, o orçamento de US\$ 85.000, em 1947, alcançou a cifra de US\$1.300.000, em 1948. Tal ampliação orçamentária foi decisiva para a negociação do acordo com a OMS. 0 orçamento estava baseado em uma cota de contribuição dos países de US $\$ 1,00$ por 1.000 habitantes, acrescida de contribuição voluntária dos seguintes países: Argentina (US\$ 400.000), Brasil (US\$ 260.000), Chile (US\$ 1.900), República Dominicana (US\$ 5.000), El Salvador (US\$2.500), México (US\$ 200.000), Venezuela (US\$ 75.000), Uruguai (US\$ 50.000).

Em informe apresentado à $2^{\mathrm{a}}$ reunião do Conselho Diretivo da Organização Sanitária Pan-Americana (México), Soper (1948) destacou a ampliação 
dos objetivos e finalidades da OPAs, a partir da XII Conferência Sanitária PanAmericana. A Oficina deveria acrescentar a seu programa os aspectos médicosanitários e de assistência médica e seguridade social, assim como deveria atuar como a Oficina Regional da Organização Mundial da Saúde no Hemisfério Ocidental, sobre a base de um acordo que se negociaria com a Organização.

Não obstante a ampliação da agenda, a febre amarela continuou como tema prioritário do Brasil ao menos nos três primeiros anos da gestão de Soper. Na reunião do Conselho Diretivo da Organização Sanitária Pan-Americana, celebrada em Buenos Aires em 1947, Heitor Praguer Froes, Diretor geral do Departamento Nacional de Saúde e delegado do Brasil, apresentou o projeto da Campanha Continental para a Erradicação do Aedes aegypti, que recomendou os seguintes pontos: 1) ser realizada mediante acordo entre os representantes dos interessados e abranger todos os países ou regiões em que existisse o Aedes aegypti; 2) ser realizada sob os auspícios da Oficina Sanitária Pan-Americana, que faria os acordos necessários, encarregando-se de reunir o pessoal técnico necessário e formar novos técnicos; 3) o financiamento se faria, quanto possível, pelos países ou regiões interessados.

As recomendações foram precedidas de uma análise da situação dos diversos países latino-americanos e dos Estados Unidos com respeito à presença de vetores da doença. Durante as décadas de 1950 e 1960, em reuniões das instâncias deliberativas da OPAs e em informes e artigos publicados no Boletim, a erradicação do Aedes aegypti constava como uma das principais preocupações para a cooperação interamericana em saúde. Também no que se refere a essa importante atividade, ocorreram tensões e divergências entre a direção da OPAS e o governo norte-americano. Em mais de uma oportunidade, Fred Soper acentuou os obstáculos para a erradicação do mosquito, lembrando o fato de os EUA terem se recusado sistematicamente a participar da campanha continental de erradicação do Aedes aegypti (Bosp, v. 55, ano 42, set. 1963).

A ampliação da agenda não implicava perda de importância do combate a doenças transmissíveis, acompanhando, ademais, tendência histórica no campo da saúde pública. 0 próprio Fred Soper (1948: 987) diria a respeito: 
Historicamente, as organizações internacionais de saúde devem em sua maior parte sua existência às enfermidades pestilenciais, à febre amarela, varíola, cólera, peste e tifo, e uma grande parte do Código Sanitário está dedicado à regulamentação relativa a essas enfermidades por tanto tempo quanto continuem existindo essas enfermidades, forçosamente constituirão uma responsabilidade primordial da organização sanitária regional.

A XIII Conferência, realizada em São Domingos, em 1950, adotou resoluções sobre estatística, educação sanitária em áreas rurais, controle de diarréias infantis e erradicação da malária. A última resolução foi acompanhada pela prescrição de fundos especiais ao orçamento de 1955 , destinados à intensificação das atividades antimaláricas.

Questões orçamentárias e político-administrativas dominaram a pauta da XIV Conferência, realizada em Santiago do Chile, em 1954. Aprovaram-se o orçamento da Oficina, o projeto de programa e orçamento da região das Américas da OMS, assim como a renovação do mandato e da designação do mesmo diretor para a Oficina Sanitária Pan-Americana e para a Oficina Regional da OMS. Declarou-se, então, a erradicação da malária como meta prioritária. Quatro anos mais tarde, durante a XV Conferência Pan-Americana de Saúde, seria eleito o primeiro latino-americano para a direção geral da entidade. No que se refere à participação de brasileiros nas instâncias decisórias da OPAS, verifica-se a presença de Heitor Pragues Froes, no Comitê Executivo, e de Marcolino Candau, que, de 1952 a 1953, ano em que é eleito diretor geral da OMS, exerceu o cargo de vice-diretor do organismo interamericano de saúde.

Não só a relação com a OMS foi tema frequiente durante a gestão de Fred Soper na Opas. Também a criação da Organização dos Estados Americanos (OEA) resultou em intenso debate sobre o grau de autonomia desejável para a entidade dedicada à saúde. Em 1950, firmou-se acordo entre a OEA e a OPAS que reconheceu formalmente a última como agência especializada de saúde do Sistema Interamericano. Após essa medida, com o apoio do governo dos Estados Unidos e das Fundações Kellogg e Rockfeller, instalou-se a primeira sede própria da Organização. 
Em termos do ensino médico, durante o período ocorreram duas importantes reuniões sobre o papel das ciências sociais, que teriam implicações nas décadas de 1960 e 1970. Tratava-se de discutir sua importância no processo de saúde, tendo como referência o ensino da medicina social.

Outra mudança importante foi a definição de divisões administrativas e programas continentais. Criaram-se a Oficina do Diretor; a Divisão de Saúde Pública - com subsetores de fomento à saúde, saneamento ambiental, doenças transmissíveis - e dois programas - erradicação do Aedes aegypti e erradicação da malária. Estabeleceram-se as divisões de administração e de educação e treinamento.

A cooperação técnica nos países e a implementação de programas continentais foram favorecidas por duas medidas: a criação de novos centros pan-americanos e a regionalização da Oficina com a criação de zonas descentralizadas. Ambas trouxeram importantes contribuições para o Brasil, devido à criação do Centro Pan-Americano de febre aftosa, em 1951, no Rio de Janeiro, e da Zona $V$ da Oficina para cuidar dos assuntos relativos ao país. Incluíam-se também entre os Centros Pan-Americanos - o Instituto de Nutrição de Centro América e Panamá (INCAP) na cidade de Guatemala, criado em 1946, e o Centro Pan-Americano de Zoonoses (Cepanzo) atual Instituto Pan-Americano de Proteção dos Alimentos e Zoonoses (InPPAZ), inaugurado em Buenos Aires, em 1956.

\section{Criação do Escritório da Zona V da Repartição Sanitária Pan-Americana}

A regionalização das atividades da Oficina consistiu em importante modificação introduzida durante a administração de Soper. Foram criadas seis oficinas de zonas descentralizadas: a Zona I, com sede em Washington, para os Estados Unidos, Canadá e territórios sem governo próprio; a Zona II, na cidade do México, para Cuba, República Dominicana, Haiti e México; a Zona III, na cidade de Guatemala, para Honduras Britânica, Costa Rica, El Salvador, Guatemala, Honduras, Nicarágua e Panamá; a Zona IV, em Lima, 
para Bolívia, Colômbia, Equador, Peru e Venezuela; a Zona V, no Rio de Janeiro, para o Brasil; e a Zona VI, em Buenos Aires, para Argentina, Chile, Paraguai e Uruguai (OPAs, 1992; Courtney, 1954). ${ }^{27}$

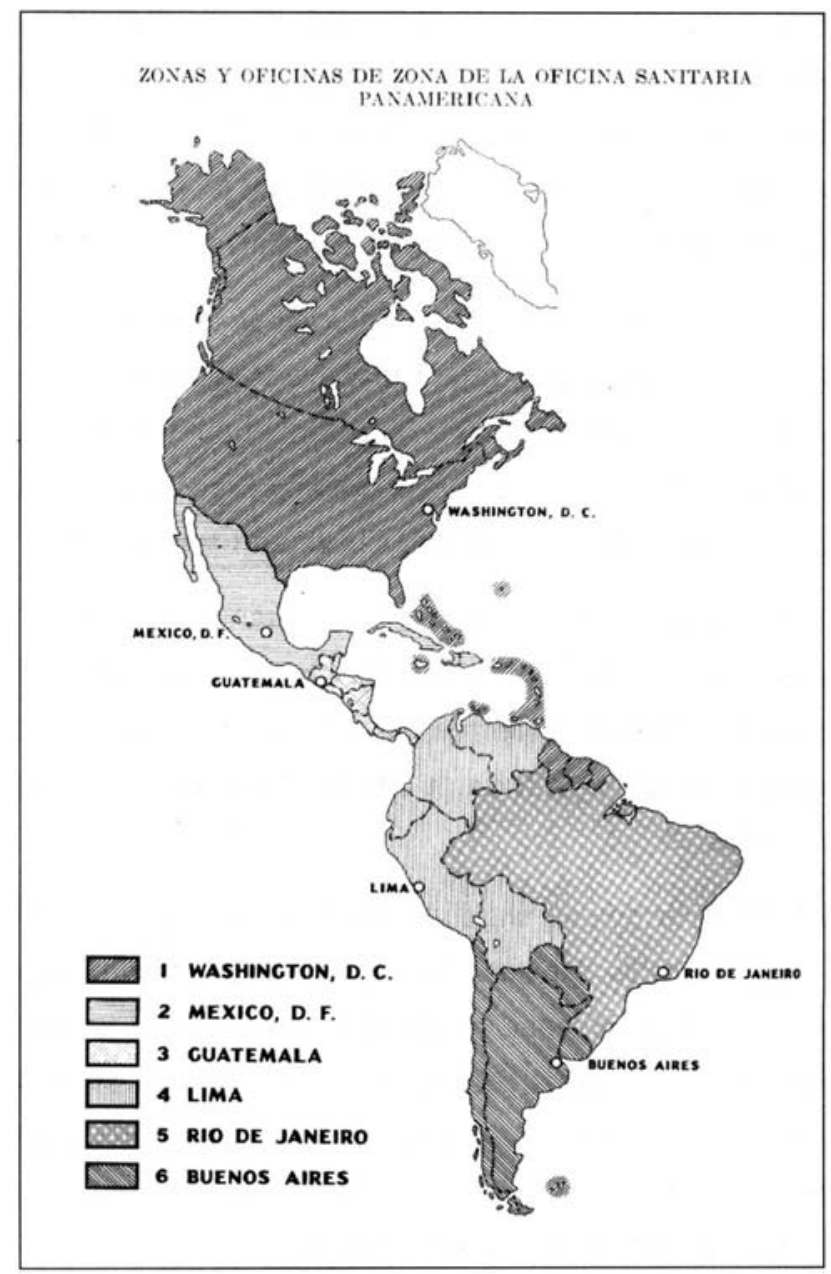

${ }^{27}$ As informações foram extraídas do Bosp (v. 36, ano 33, n.5, maio. 1954) e referem-se ao período de atuação de Kenneth Courtney, segundo artigo de sua autoria. 
Em julho de 1951, foi firmado convênio entre a Opas e o governo do Brasil, que estabeleceu o Escritório de Zona para representar a OpAs no país. 0 primeiro representante, Kenneth Courtney, foi designado em outubro do mesmo ano. De 1954 a 2002, atuaram como representantes do organismo no país: Hector Argentino Call, Donald Damude, Santiago Renjifo, Raul Vera, Vasquez Vigo, Jorge Athins, Manuel Sirvent-Ramos, Frederico Bresani, Carlos Davila, Florentino Garcia Scarponi, Francisco Salazar, Enrique Najera Morrondo, Ramon Alvarez Gutierrez, Hugo Villegas, Rodolfo Rodrigues, David Tejada, Armando Lopez Scavino e Jacobo Finkelman.

A montagem do Escritório de Zona da Opas no Brasil ocorreu no mesmo período em que o país criava uma pasta autônoma para a área, o Ministério da Saúde, criado em 1953. Da estrutura do ministério faziam parte o Departamento Nacional de Saúde, o Serviço Especial de Saúde Pública, o Departamento Nacional da Criança e o Instituto Oswaldo Cruz.

O Escritório da Zona $\mathrm{V}$, além de assessorar as autoridades sanitárias federais e estaduais, prestou assistência na obtenção de materiais e equipamentos de saúde pública e colaborou em diversos programas, com destaque para o programa de febre amarela, a criação do Panaftosa e o programa de bolsas de estudos.

Em 1950, firmou-se um convênio entre o Departamento Nacional de Saúde e a Repartição Sanitária Pan-Americana, estabelecendo cooperação com vistas a uma campanha continental contra a febre amarela. 0 Instituto Oswaldo Cruz e o Serviço Nacional de Febre Amarela do Departamento Nacional de Saúde do Brasil, por meio da OPAS, proporcionariam serviços patológicos, sorológicos e de diagnóstico, como também forneceriam vacina contra febre amarela para uso nas Américas.

A criação do Centro Pan-Americano de Febre Aftosa - Regional 77 - representou outro marco importante nessa nova fase de relação entre a OpAs e o Brasil. Com verbas designadas pelo Conselho Econômico e Social da Organização dos Estados Americanos e a aceitação da oferta do Brasil para 
sediar o novo organismo, instalou-se, em 1951, com a incumbência de proporcionar: 1) serviços de diagnóstico aos países que enviassem amostras; 2) serviços de assessoramento e consulta aos países latino-americanos que encaminhassem pedidos de assistência em programas de combate à febre aftosa ou prevenir sua introdução nos respectivos territórios nacionais; 3) cursos de adestramento aos veterinários dos Departamentos de Agricultura dos diversos países da América Central, Antilhas e América do Sul no campo da prevenção, diagnóstico e profilaxia da febre aftosa. (A criação e as conquistas da Panaftosa são apresentadas em texto complementar, que se integra a este capítulo).

Deve também ser destacado o programa de bolsas de estudo concedidas a médicos, engenheiros, enfermeiros, veterinários e técnicos de laboratório brasileiros para estudos no país ou no exterior, assim como de estrangeiros para estudos no Brasil. Igualmente importantes foram os Programas de Higiene Materno-infantil, em cooperação com a Unickf, e de Adestramento em Sorologia de Doenças Venéreas, em cooperação com a Faculdade de Higiene e Saúde Pública da Universidade de São Paulo (Courtney, 1954).

\section{Sob o signo do desenvolvimento e da medicina social: as relaçóes entre o Brasil e a OPAS no período 1958-1982}

Uma das mais importantes transformações ocorridas na sociedade brasileira durante a segunda metade do século XX consistiu no processo de urbanização. Ainda rural em 1960, duas décadas mais tarde tornarase o Brasil um país de população predominantemente urbana. Esse percentual, que era de $31,2 \%$ em 1940 , passou a $44,7 \%$ em 1960 , e a $67,6 \%$ em 1980, com sensível aumento na velocidade da mudança na década de 1960, quando se deu a efetiva inclusão do país na faixa das nações urbanas (Santos, 1985). Tal processo influenciou as condições ambientais 
e sociais das cidades, dado seu impacto na infra-estrutura de serviços públicos e nas condições de saúde, trabalho e habitação.

Esse quadro suscitou os debates sobre as políticas de saúde nas décadas de 1960 e 1970 , intensificando os estudos sobre pobreza urbana e suas relações com temáticas sanitárias. Com ritmo e características próprias, outros países latino-americanos enfrentaram o mesmo dilema de promover o desenvolvimento e garantir acesso aos bens e serviços básicos. A Opas desempenhou papel de destaque nesse processo, inclusive ao participar ativamente da própria definição do que deveria ser considerado desenvolvimento, bens e serviços básicos e qualidade de vida.

No plano político, a experiência de regimes autoritários marcaria por longo período os países latino-americanos. De 1964 a 1985, viveu 0 Brasil sob a égide de governos militares, que implementaram um modelo de Estado altamente centralizado, além de planos de desenvolvimento que trariam significativo impacto para a estrutura econômica e social do país. A análise desse complexo processo vem sendo realizada de forma consistente em estudos de especialistas de diferentes áreas disciplinares, ainda que nem sempre as questões referidas às suas implicações para os processos de saúde/doença e qualidade de vida mereçam tratamento mais sistemático e aprofundado.

Em termos do quadro internacional, a região das Américas experimentou grande expansão econômica de fins da década de 1950 até meados da década de 1970, quando os efeitos da crise mundial trouxeram importantes resultados adversos, com altas taxas de inflação e redução no ritmo do crescimento. Vale lembrar que o período foi dominado pela chamada Guerra Fria e pelo impacto no continente americano da Revolução Cubana. Notese que a OPAS/OMS foi a única organização regional a não excluir Cuba de seus quadros, além de apoiar e utilizar a experiência desse país nas áreas de desenvolvimento tecnológico em saúde e de ações assistenciais, como o programa de médico de família (Macedo, 1977). 
A intenção desta seção não consiste em proceder ao inventário das múltiplas iniciativas adotadas pela OPAs no período, ou mesmo elencar todas as ações do organismo que se relacionam com idéias, projetos e políticas de saúde no Brasil. Mais uma vez, não podendo fazer justiça à diversidade de temas pertinentes para os propósitos deste trabalho, elegeram-se algumas questões concernentes à história institucional e sua interface com importantes iniciativas que ocorreram no país. Para tanto, inicialmente apresento as diretrizes centrais durante as gestões de Abrahan Horwitz e Héctor Acuña, com ênfase nas resoluções e iniciativas referidas aos programas de maior impacto para o Brasil.

Em um segundo momento, destaco a importância das atividades iniciais do Programa Ampliado de Imunizações, estabelecido formalmente nas Américas em 1976. Ao fazê-lo, considero tanto a importância de seus resultados para a saúde do Brasil e das Américas, como a experiência peculiar do Brasil no programa de erradicação da varíola e, principalmente, o que revela da potencialidade de ações coletivas em âmbito continental.

As realizações no campo dos recursos humanos e, fundamentalmente, a influência na consolidação da perspectiva da medicina social são, a seguir, examinadas. Experiências institucionais inovadoras no Brasil, principalmente na criação de cursos de pós-graduação, são ressaltadas ao mesmo tempo que se registram suas afinidades com a gestação do movimento sanitarista de fins da década de 1970. No que se refere a esse amplo campo de atividades, destaca-se finalmente a visão estratégica sobre o conhecimento e a atualização bibliográfica e desenvolvimento de consistente programa de informação. A criação, os propósitos e perspectivas da Bireme são ressaltados em texto complementar, que se integra a este capítulo.

Tomando como pontos fundamentais os temas do desenvolvimento e da medicina social, pretende-se destacar a forma como a agenda proposta pela OpAs, ao mesmo tempo, influenciou e se forjou a partir de forte interação com instituições e intelectuais brasileiros. Um espaço institucional de funda- 
mental importância nesse processo foi o Programa de Preparação Estratégica de Pessoal de Saúde (PrRePs), criado em 1975 por convênio entre o governo brasileiro e a OPAs.

\section{Sob o signo do desenvolvimento}

0 conceito de desenvolvimento encontra-se entre os que mais definições, revisões e qualificações recebeu. Desenvolvimento - econômico, social, humano, sustentável: são termos que se sucederam desde o final da década de 1950 e que também levariam, cada um deles, a um inventário de múltiplos significados e concepções divergentes. No início dos anos 1960, dominava o debate teórico e prático em áreas diversas do conhecimento $\mathrm{e}$ da implementação de políticas e teve presença marcante na proposta da saúde como um direito.

A qualificação do desenvolvimento como econômico e social orientou a Carta de Punta del Leste, firmada, em 1961, em reunião especial do Conselho Interamericano Econômico e Social. 0 documento definiu dois objetivos gerais: aumentar a esperança de vida em no mínimo cinco anos e ampliar a capacidade para a aprendizagem e a produção mediante o melhoramento da saúde individual e coletiva. Como objetivos específicos, estabeleceu 0 abastecimento de água e saneamento, a redução da mortalidade infantil, o controle das enfermidades transmissíveis, melhoras na nutrição, capacitação e desenvolvimento de pessoal de saúde, fortalecimento de serviços básicos e intensificação da investigação científica (OPAs, 1992).

0 documento reconhecia a saúde como componente essencial do desenvolvimento, enfatizando a necessidade do planejamento, sob a condução do Estado, para a consecução dos objetivos nacionais de bem-estar, democracia e segurança. Em termos políticos e estratégicos, deu fundamentos para a Aliança para o Progresso, proposta pelos EUA, para a cooperação regional e para a legitimação, civil e política, da doutrina de segurança nacional desenvolvida pelo Colégio Interamericano de Defesa. Um ano antes, 
reunião realizada em Bogotá já havia contribuído para esse processo mediante o estabelecimento de Fundo para o Desenvolvimento Econômico e Social.

Em 1963, a Opas convocou uma reunião de ministros de saúde com a missão de estabelecer o Plano Decenal de Saúde Pública para as Américas, calcado na compreensão da saúde como problema técnico, social, econômico, jurídico e cultural. Estabeleceu-se também associação com o Banco Interamericano de Desenvolvimento denominado por Abrahan Horwitz "Banco de saúde", o que permitiu o investimento em programas de saúde no continente durante as décadas de 1960 e 1970 (OPAs, 1992).

Outra associação frequiente estabeleceu-se entre saúde e riqueza e doença e pobreza. 0 tema não era novo, mas tendia a prevalecer a idéia de que o desenvolvimento econômico, ao promover um ambiente social adequado, implicaria aumento da expectativa de vida e de melhores condições de saúde física, mental e social. Note-se que durante a década de 1960, entre as teses sobre desenvolvimento que influenciavam os debates nos organismos internacionais de saúde, destacam-se as do economista sueco Gunnar Myrdal. Para ele, o êxito dos programas de saúde dependia do desenvolvimento simultâneo de outros programas, como o aumento da produção agrícola, a melhoria da educação e a redução da pobreza absoluta (Myrdal, 1968).

A associação entre urbanização intensa, pobreza e doença era constante, reeditando, em novas bases, o impacto do fenômeno urbano do século XIX a que nos referimos no início deste capítulo. Muitos pronunciamentos do diretor geral da OMS, Marcolino Candau, referem-se a esse problema. Aliás, sua gestão no organismo mundial de saúde também mereceria análise mais aprofundada, uma vez que o sanitarista brasileiro permaneceu no cargo por vinte anos e vinha de uma experiência, já mencionada, de organização de ações de saúde no Brasil e na vice-direção da Opas. Os balanços históricos sobre a OPAs tendem a conferir maior atenção a relações entre os dois organismos no período em que essas foram particularmente difíceis, antes da assinatura do acordo que a definiu como Oficina regional da Américas, em 1949. 
Na América Latina, a CEPAL desempenhou papel de relevo ao problematizar o conceito de desenvolvimento como equivalente a crescimento econômico, sem que mudanças estruturais fossem propostas. Inúmeras críticas foram formuladas, desde então, quer às perspectivas que conferiam ao termo o sentido de progresso linear, ou de mudança nos países 'retardatários' sob o impulso das nações já desenvolvidas, quer à pertinência do conceito alternativo de dependência e às possibilidades explicativas dessa teoria para os países latino-americanos. Para os propósitos deste trabalho, trata-se de acentuar 0 intenso clima de debates teóricos e políticos e de como os organismos internacionais de saúde atuaram de forma efetiva nesse processo.

No Brasil, durante as décadas de 1950 e 1960, uma das mais importantes correntes de pensamento em saúde pública ficou conhecida como sanitarismo desenvolvimentista. De acordo com Eliana Labra (1988), suas principais características encontravam-se na crítica ao modelo campanhista e à inversão dos termos propostos pelo movimento sanitarista da Primeira República que enfatizara o papel da saúde no progresso nacional e na própria formação da nacionalidade brasileira. Para o sanitarismo desenvolvimentista, "o nível de saúde de uma população depende em primeiro lugar do grau de desenvolvimento econômico de um país" (Labra, 1988). Reunindo intelectuais como Mario Magalhães da Silveira, Samuel Pessoa e Josué de Castro, esta concepção predominou durante a III Conferência Nacional de Saúde e é vista, pelo movimento sanitarista mais recente, como precursora das propostas posteriores de reforma do setor saúde e das teses consagradas durante a VIII Conferência.

De acordo com Madel Luz (1979: 43), essa corrente conseguiu formular:

definições básicas sobre como deveriam ser os Planos de Saúde, tendo por base uma filosofia de ação calcada na demonstração das relações entre saúde e economia, necessidade de uma estrutura permanente de saúde, definição de que essa estrutura deveria ser de responsabilidade municipal embora com assistência técnica e mesmo financeira de oùtras esferas de governo. 
Propostas de ação informadas pelo binômio saúde e desenvolvimento orientaram as atividades da Opas na gestão de Abrahan Horwitz. E interessante observar que nessa equação a perspectiva da instituição foi inovadora ao incluir como temas prioritários o saneamento e o ambiente. Após a segunda reunião de ministros da Saúde, realizada em Buenos Aires, em 1968, a Opas, que já atuava como principal organismo de cooperação técnica para água potável e saneamento, criou o Centro Latino-Americano de Engenharia Sanitária. Como uma das iniciativas relacionadas a essa cooperação, realizou-se no Brasil, em 1969, inquérito sobre abastecimento de água e serviços de esgoto em capitais brasileiras. A defesa de uma concepção mais ampla que não se restringisse ao saneamento motivou a criação do Centro Pan-Americano de Ecologia Humana de Saúde (ECO), com sede no México, em 1974. 0 sentido mais amplo das relações entre ambiente e saúde foi contemplado a partir da década de 1980 com o apoio, entre outras iniciativas, à criação dos Centro de Estudos em Saúde do Trabalhador e Ecologia Humana na Fundação Oswaldo Cruz. ${ }^{28}$

Em 1972, a $3^{\mathrm{a}}$ reunião especial de ministros da Saúde, em Santiago do Chile, aprovou o Segundo Plano Decenal de Saúde para a Região. Seu eixo fundamental está constituído pela afirmação da saúde como um direito fundamental do indivíduo e das populações, a responsabilidade dos Estados em assegurar esse direito a todos e a estratégia de expansão das coberturas com serviços de saúde visando à sua universalidade. 0 Plano estabeleceu novas metas para 1980: população urbana $-80 \%$ com água potável e $70 \%$ com esgotos sanitários - e população rural - $50 \%$ para água potável e sistema de esgoto (OPAs, 1992).

Ao longo da gestão de Horowitz, intensificaram-se os programas de bolsas de estudo e diversas outras iniciativas destinadas à formação de recursos humanos. Algumas políticas haviam sido esboçadas anteriormente no período em que atuou como coordenador de educação e treinamento da

\footnotetext{
${ }^{28}$ Depoimento de Jacobo Finkelman, concedido a Nísia Trindade Lima para o Acervo da Casa de Oswaldo Cruz, 2002.
} 
Opas. ${ }^{29}$ Em 1972, foi criado o Programa Especial de Pesquisa, Desenvolvimento e Treinamento em Reprodução Humana.

No campo da formação profissional e ensino, o Programa de LivrosTexto da Opas tornou acessível a estudantes e professores literatura especializada. As metas de divulgação da informação, de modo sistemático e altamente profissionalizado, já haviam levado ao estabelecimento, em 1967, em São Paulo, da Biblioteca Regional de Medicina e Ciências da Saúde (BIREME), que estabeleceu uma rede pan-americana de informação biomédica e social (OPAs, 1992). Durante esses 35 anos, a Bireme tem desempenhado papel importante, inclusive na intensificação das trocas intelectuais e do intercâmbio de bibliografia e informações entre o Brasil e os demais países latino-americanos.

Com o objetivo de adaptar a tecnologia docente à política de saúde e ao sistema de saúde em cada país, a Organização apoiou a criação do Centro Latino-Americano de Tecnologia Educacional para a Saúde (Clates) no Rio de Janeiro. Um ano mais tarde, seria fundado novo Clates no México. Esses centros passaram a ser financiados pelos próprios países e o implantado no Rio de Janeiro deu origem ao atual Núcleo de Tecnologia Educacional em Saúde (Nutrs/UFRJ). Em 1973, também com o apoio da Opas, da Fundação Kellog e da Financiadora de Projetos (FineP), criou-se o curso de pós-graduação em medicina social da Universidade do Estado do Rio de Janeiro (UERJ).

$\mathrm{Na}$ área das doenças transmissíveis, a erradicação do Aedes aegypti continuou como meta do organismo, mas, a julgar por alguns artigos publicados no Boletim, não apresentava resultados muito animadores (Soper, 1968). A maior realização, no que se refere a essas doenças, consistiu na erradicação da varíola. Em 1973, a $22^{2}$ reunião do conselho diretor da OpAS declarou a varíola erradicada nas Américas. A erradicação mundial da varíola foi anunciada pela OMS em 1979; na América, a primeira resolução da OPAS sobre erradicação data de 1952.

\footnotetext{
29 Depoimento de José Roberto Ferreira, concedido a Nísia Trindade Lima para o Acervo da Casa de Oswaldo Cruz, 2002.
} 
0 estabelecimento do Programa Ampliado de Imunização (PAI) nas Américas viria a ser uma das principais iniciativas do novo período de gestão da OpAs, com a eleição, em 1974, pela XIX Conferência Sanitária Pan-Americana, de Héctor R. Acuña, do México. Em 1976, o PAI foi estabelecido nas Américas com o objetivo de ampliar a cobertura vacinal dos grupos mais suscetiveis à poliomielite, ao sarampo, ao tétano, à coqueluche, à difteria e à tuberculose (Macedo, 1977).

Em 1977, a Assembléia Mundial de Saúde aprovou o PAI; em larga medida, uma decorrência do sucesso da erradicação da varíola e de avanços no desenvolvimento tecnológico e produção de vacinas. 0 Programa foi criado pelos governos membros da OMS para coordenar os esforços de promoção e apoio do uso de vacinas em todo o mundo. Na mesma Assembléia, declarou-se a meta de "saúde para todos no ano 2000".

Outras iniciativas adotadas em 1975, no âmbito da OMS, teriam importância para 0 alcance desse objetivo. A preocupação com os ainda altos índices de mortalidade infantil determinou o estabelecimento do Programa Mundial de Luta contra as Diarréias que estabelece a utilização de soluções para reidratação oral. Nessa mesma Assembléia, foram adotados o conceito de medicamentos essenciais e a utilização de genéricos para os produtos sem proteção de propriedade, definindo-se ainda a estratégia da Atenção Primária à Saúde.

\section{Erradicação da varíola e Programa Ampliado de Imunização}

A erradicação da varíola consiste em tema de grande interesse para os estudiosos dos fenômenos da saúde coletiva e os gestores dos sistemas de saúde. Resultado do esforço articulado de diferentes atores institucionais, revela ainda forte associação entre conhecimento epidemiológico e ações de saúde pública. Uma das primeiras doenças a ser combatida por meio da 
vacinação, apenas durante a década de 1950 passou a varíola a figurar nas resoluções da Opas em termos de uma meta de erradicação. Não foram poucas as controvérsias científicas sobre o tema. Registre-se, por exemplo, o intenso debate sobre a univacinação durante a IX Conferência Pan-Americana de Saúde. Os estudos históricos têm demonstrado o quanto foi difícil estabelecer a vacina como fato científico, algo que não se resume aos episódios de reação popular como a Revolta da Vacina do início do século XX.

Na década de 1960, o Brasil era o único país das Américas ainda endêmico com relação à variola. Nesse período, a iniciativa da OMS de erradicar a doença teve muitas implicações para o país, instituindo-se em 1966, por Decreto Federal, a Campanha de Erradicação da Varíola. 0 apoio da OpAs às ações então implementadas ocorreu em diversas linhas de assistência técnica, em conformidade com o programa da OMS: produção e controle de qualidade de vacinas, consultoria técnica, veículos e equipamentos de vacinação. ${ }^{30}$

A Campanha de Erradicação da Varíola, realizada de 1966 a 1973, teve importante impacto para as ações de controle de doenças transmissíveis no Brasil. Por um lado, contribuiu para a formação de quadros profissionais com experiência no planejamento e execução de programas de vacinação e em atividades de investigação epidemiológica. Por outro, no plano da organização das ações de saúde, permitiu a inserção dessas atividades nas secretarias estaduais de saúde, mediante a criação de unidades de vigilância epidemiológica apoiadas pela Fundação Sesp. A experiência acumulada contribuiu para a formulação e execução do Plano Nacional de Controle da Poliomielite (1971-1973), do Programa Nacional de Imunizações (1973) e da Campanha Nacional de Vacinação contra a Meningite Meningocócica (1975).

o Plano Nacional de Controle da Poliomielite baseava-se na realização de campanhas de vacinação em um só dia, em âmbito estadual. Apesar

\footnotetext{
${ }^{30}$ Agradeço a João Baptista Risi Jr. pelas informações e comentários a respeito desta seção.
} 
de nem todos os estados terem sido cobertos, tal experiência fundamentou a estratégia de "dias nacionais de vacinação" implantada no Brasil a partir de 1980. A criação do Programa Nacional de Imunizações (PNI) ocorreu ao mesmo tempo em que se extinguia a Campanha de Erradicação da Varíola e se incorporavam ao novo programa as atividades de controle da poliomielite. Deve-se registrar que o PNI antecedeu o PAI.

Após a constituição do Programa Ampliado de Imunização pela OPAS/ OMS, algumas iniciativas desse organismo desempenharam papel relevante na consolidação do programa brasileiro. Destacam-se, entre elas, o 'fundo rotatório' para compra de vacinas, o suporte técnico a diferentes ações, inclusive na área de produção de vacinas, e o desenvolvimento do sistema de refrigeração das vacinas (cadeia de frio), de grande importância em um país com dimensões continentais e grandes contrastes sociais, e também bastante desigual no que se refere à densidade demográfica de suas regiões.

A estratégia de campanhas de vacinação não ocorreu sem suscitar uma série de controvérsias e críticas por parte dos que ressaltavam que as atividades de imunização deveriam ser integradas à atenção básica, centrada na rotina de serviços permanentes, em lugar de serem objeto de programas especiais. Tal concepção predominou tanto no Brasil como na Opas/OMS durante o período de 1974 a 1979. Nesse período, organizaram-se, também em âmbito nacional, as atividades de vigilância epidemiológica de poliomielite.

A identificação de contradições entre estratégias de campanha e o foco na atenção primária à saúde não se constituiu como uma peculiaridade do sanitarismo brasileiro, encontrando-se presente nos fóruns internacionais organizados pela Opas/OMS. No âmbito desse organismo, estudo independente realizado na década de 1990 concluiria pela possibilidade de superar perspectivas dicotômicas entre atenção primária e campanhas de imunização, apontando o impacto positivo da campanha de erradicação da poliomielite no desenvolvimento dos serviços de assistência à saúde (OPAs, 1995). 
Em 1979, instituíram-se, no Brasil, os "dias nacionais de vacinação contra a poliomielite", estratégia alvo de críticas segundo a perspectiva já mencionada, tanto por parte de sanitaristas brasileiros como pelos organismos internacionais. A OPAS reconheceu a pertinência e eficácia do programa realizado no Brasil com antecedência em relação à OMS, merecendo destaque a contribuição do país para a decisão, em 1985, de se erradicar a transmissão autóctone de poliovírus selvagens nas Américas. 0 argumento decisivo foi a demonstração de que, em um país com a dimensão e a complexidade do Brasil, era possível planejar, executar, avaliar e manter a estratégia dos "dias nacionais de vacinação". Na fase de implementação do plano de erradicação da poliomielite, de 1985 a 1994, foi possível contar com o apoio político, técnico e operacional da OPAs que também favoreceu a ampliação do PNI, com destaque para os resultados alcançados no que se refere ao sarampo.

\section{Sob o signo da medicina social}

Propostas sobre a formação de profissionais afinados com novas concepções de saúde pública, que substituíssem o tradicional domínio da higiene, começaram a ganhar corpo na Opas a partir da década de 1950. Sob a coordenação de Abrahan Horowitz, coordenador de educação e treinamento durante a gestão de Fred Soper e, a seguir, diretor geral do organismo, iniciativas importantes ocorreram na formação de recursos humanos e, simultaneamente, na difusão de novas propostas para o ensino médico e para o desenvolvimento de novos modelos de escolas de saúde pública.

Como observa em seu depoimento, José Roberto Ferreira, coordenador de recursos humanos da OPAs, de 1975 a 1986:

Criou-se o Programa de Bolsas de Estudos realmente agressivo, no qual se estabeleceu em Assembléia que $25 \%$ do orçamento seria destinado às bolsas. (...) foi talvez a atividade mais importante no campo de formação de pessoal em treinamento de saúde pública e medicina preventiva. 
A história da educação e formação profissional na área da saúde na América Latina tem como importante marco o Seminário sobre o Ensino de Medicina Preventiva, realizado em Viña del Mar, no Chile, em 1955. Durante esse evento, foram apresentadas propostas alternativas ao modelo de organização da educação médica proposto no relatório do educador norte-americano Abraham Flexner, predominante no continente americano desde a segunda década do século XX. A partir do Seminário de Viña del Mar, intensificou-se a criação de departamentos de medicina preventiva ou social em vários países.

No Brasil, o Departamento de Medicina Preventiva da Faculdade de Medicina de Ribeirão Preto firmou-se mediante um processo em que os Seminários de Medicina Preventiva e Social organizados pela Opas exerceram importante influência. A experiência de Ribeirão Preto destacava-se, entre outros aspectos, pela grande importância atribuída à saúde pública em um centro de formação médica. De acordo com o depoimento de José Roberto Ferreira:

o Departamento era muito importante, a tal ponto que conseguiu uma coisa raríssima que nunca mais se projetou em nenhum outro lugar. Ele era um centro de medicina preventiva e responsável por todos os assuntos especiais da Escola. 0 Hospital (...) era dirigido por um departamento de saúde pública! Era uma coisa rara...

A Opas, a partir da década de 1960, intensificaria suas ações para promover a reformulação de cursos de saúde pública e difundir abordagens críticas ao modelo de história natural da doença, propondo como alternativa a multicausalidade. A utilização das ciências sociais em saúde receberia forte estímulo, delineando-se tanto uma corrente baseada no movimento preventivista de origem norte-americana, marcada pela ênfase na organização liberal da prática médica, como perspectivas histórico-estruturais que realçavam o papel central a ser desempenhado pelo Estado (Arouca, 1975; Escorel, 1998).

Uma das principais iniciativas nesse contexto foi a realização de ampla pesquisa sobre educação médica na América Latina, coordenada pelo 
sociólogo Juan César Garcia, com o apoio da Opas e da Fundação Milbank. Esse trabalho estimulou a criação de cursos de pós-graduação em medicina social, em diferentes países, e a revisão das abordagens predominantes em centros e institutos de saúde pública. Em 1973, criou-se o primeiro curso de medicina social na Universidade do Estado do Rio de Janeiro (Instituto de Medicina Social - UerJ), com apoio da Opas, da Fundação Kellog e da principal agência de fomento à pesquisa no Brasil daquele período - a Financiadora de Estudos e Projetos (Finep). Um ano mais tarde, organizou-se o curso de pós-graduação em medicina social de Xochimilco, na Universidade Autônoma do México (Escorel, 1998; Nunes, 2002).

No início da década de 1980, verificava-se a institucionalização, no Brasil, da abordagem da medicina social, ainda que, naturalmente, comportasse inúmeras clivagens e diferenciações nos planos teórico e político. Encontrava-se representada pelos seguintes centros: os departamentos de medicina preventiva da Universidade de Campinas (Unicamp) e da Universidade de São Paulo (USP), o Instituto de Medicina Social da UerJ e pela Escola Nacional de Saúde Pública (ENsP), ${ }^{31}$ na Fundação Oswaldo Cruz (Fiocruz) (Escorel, 1998; Teixeira, 1985). Uma das implicações desse processo foi a incorporação de cientistas sociais aos quadros docentes dessas instituições. No que se refere ao instrumental analítico adotado, pode-se, em um primeiro momento, identificar o predomínio de abordagens marxistas e do pensamento de Michel Foucault. ${ }^{32}$

O estudo de Sarah Escorel (1998) sobre o movimento sanitário brasileiro das décadas de 1970 e 1980 traz importante contribuição ao demonstrar o quanto essa base institucional, em que se verifica o apoio efetivo de organismos internacionais como a OPAs, teve papel decisivo ao constituir a

\footnotetext{
${ }^{31}$ No caso da Ensp/Flocruz, devem ser consideradas as experiências dos Programas de Estudos Socioeconômicos em Saúde (PEses) e o de Estudos e Pesquisas Populacionais e Epidemiológicas (PEPPE), implementados com a cooperação entre a Fundação Oswaldo Cruz e a FinEP (Teixeira,1985).

${ }^{32}$ Para uma crítica da apropriação dessas perspectivas no campo da saúde coletiva, ver o artigo de Rezende de Carvalho \& Lima (1992).
} 
base acadêmica, ou universitária, para a articulação do movimento. Tais espaços foram também fóruns de debates para os projetos e teses que viriam mais tarde a ganhar notável visibilidade durante a VIII Conferência Nacional de Saúde. Realizada no período de redemocratização, a Conferência incluiu em seu temário três questões principais: a saúde como dever do Estado e direito do cidadão, a reformulação do Sistema Nacional de Saúde e o financiamento setorial, dando relevo às relações entre saúde e democracia.

No mesmo estudo, apontam-se outros antecedentes do movimento sanitarista, especialmente iniciativas vinculadas ao II Plano Nacional de Desenvolvimento, implementado durante o Governo Geisel (1974-1978). Segundo a autora:

Diretamente vinculados ao II PND, surgiram nessa conjuntura três espaços institucionais que podemos chamar de pilares institucionais, estímulos oficiais à estruturação/articulação do movimento sanitário: 0 setor saúde do Centro Nacional de Recursos Humanos do Instituto de Pesquisa Econômica e Aplicada (CNRH/IPEA), a Financiadora de Estudos e Projetos (FingP) e o Programa de Preparação Estartégica de Pessoal de Saúde da Opas (PrReps /Opas). (Escorel, 1998)

O Programa de Preparação Estratégica de Pessoal de Saúde/OPaS surgiu como conseqüência da criação, pelo Ministério da Saúde, de um grupo de trabalho interministerial dedicado a formular propostas na área de formação e distribuição de pessoal de saúde para o II PND. Em 1975, o Governo brasileiro assinou convênio com a 0PAS/OMS para implementar as ações de formação e distribuição de pessoal de saúde, criando o PPreps. Sua condução ficou a cargo de comissão composta por representantes dos ministérios da Saúde e da Educação e Cultura e da OPAs, sob a presidência do secretário geral do Ministério da Saúde - José Carlos Seixas, e secretariadas pelo coordenador do Grupo Técnico do Ppreps, Carlyle Guerra de Macedo.

De 1975 a 1978, o PrReps desenvolveu projetos de treinamento e desenvolvimento de recursos humanos com as secretarias estaduais de saúde, de integração docente assistencial, a cargo de universidades e de 
tecnologia educacional, executado pelo Nưes/Ciates. A área de desenvolvimento de recursos humanos teve impactos locais expressivos, sobretudo no Nordeste, e desenvolveu-se de forma articulada ao Programa de Interiorização de Ações de Saúde e Saneamento (Piass) (Escorel, 1998).

Ao acentuar o papel da OpAs na configuração de espaços acadêmicos e na implementação de políticas públicas de formação de recursos humanos na área de saúde, coloco em evidência a contribuição desse organismo para a institucionalização da perspectiva da medicina social no Brasil. Uma segunda dimensão que também deve ser realçada consiste no seu reverso, ou seja, quanto essas experiências repercutiram no desenvolvimento de programas pela 0pas. 0 compartilhamento com técnicos brasileiros na condução de projetos e os desafios enfrentados na implementação prática de propostas para a saúde consistiram, certamente, em uma base para outras iniciativas da organização.

\section{O Brasil e as propostas de promoção da saúde a partir da década de 1980}

Quando se criou a OPAS seu objetivo manifesto era combater as doenças infecciosas para estimular o comércio entre as nações. Atualmente se proclama a saúde como direito bumano e como fundamento da paz entre as nações. Carlyle Guerra de Macedo (Bosp, v.100, n.1, jan.1986)

A visão retrospectiva sobre a OpAs põe em evidência temas que não seriam observados se nos limitássemos ao conceito mais restrito de saúde. Evitando o risco de anacronismo, uma das constatações que se fazem imperiosas é exatamente o alargamento da agenda da saúde, em grande medida relacionado ao aumento da consciência sobre a interdependência nas sociedades humanas no final do século XX. 
A idéia da saúde como direito humano, reiterada nas declarações de todas as conferências e assembléias mundiais, desde Alma-Ata, não tem implicado, entretanto, uma agenda consensual de como lidar com problemas como equidade, justiça e cidadania, centrais para qualquer definição programática no campo da saúde. Entretanto, ao reiterar a concepção da saúde como direito e bem público, a OPAS vem desempenhando importante papel no continente, aliando a essa perspectiva a defesa da paz. De certo modo, pode-se dizer que o organismo seria uma voz dissonante diante da ênfase, no cenário internacional, de propostas que enfatizam o mercado e a focalização e seletividade como fundamentos desejáveis das políticas sociais.

Nesta última seção do capítulo, situarei as relações entre a OPAS e o Brasil desde 1983, período que compreende as gestões de Carlyle Guerra Macedo e George Aleyne. Novamente, a proposta não pode ser a de realizar levantamento exaustivo de todos os planos e realizações, mas sim de selecionar algumas questões centrais para a compreensão das idéias e propostas relacionadas à agenda de saúde no Brasil e nas Américas.

Inicialmente, procurei situar problemas que emergem na década de 1980 e que se expressam nos temas do ajuste estrutural e da redução do papel do Estado na oferta de bens e serviços de natureza social. No caso do Brasil, observam-se algumas tendências que emergem a partir dessas reconfigurações, destacando-se as características peculiares da reforma do setor saúde com a implantação do SUS.

A seguir, apresento as principais diretrizes e programas da OPAs no período, destacando os temas da erradicação da poliomielite nas Américas e da associação entre promoção da saúde e desenvolvimento. De certo modo, retomam-se as questões abordadas na seção anterior, situando-as, entretanto, em um novo contexto.

0 'otimismo sanitário' das décadas de 1950 e 1960 parece ao olhar contemporâneo uma atitude distante da realidade, seja no que se refere aos problemas derivados da crise econômica dos anos 1980, seja diante dos 
problemas relacionados às doenças transmissiveis, que, ao contrário dos prognósticos otimistas da década de 1950 , continuam a merecer atenção especial nos programas de saúde, inclusive com epidemias de novas doenças como a Aids. ${ }^{33}$ Entretanto, ao contrário de propor sua substituição por qualquer modalidade de 'pessimismo sanitário', considero que situar esse complexo conjunto de questões em perspectiva histórica contribui para estabelecer um diálogo entre os diversos atores que constroem o campo da saúde coletiva.

\section{A agenda da saúde no Brasil e o papel dos organismos internacionais}

A década de 1980 foi marcada por grave crise mundial, cujas consequiências em termos de desequilíbrios macroeconômicos, financeiros e de produtividade atingiram a economia internacional. Em resposta a essa crise, verificou-se intenso processo de internacionalização dos mercados, dos sistemas produtivos e da tendência à unificação monetária, cujo resultado foi uma perda considerável da autonomia dos Estados nacionais.

$\mathrm{Na}$ América Latina, os efeitos da crise financeira, somados à explosão da crise da dívida externa, levaram a um reforço do modelo que vinha sendo aplicado em alguns países desde meados da década anterior pelo Banco Mundial, o Fundo Monetário Internacional (FMI) e o governo americano, no chamado "Consenso de Washington". Nesse modelo está a proposta de ajuste estrutural, segundo a qual as mudanças deveriam ocorrer através de políticas liberalizantes, privatizantes e de mercado, ou seja, centradas na desregulamentação dos mercados, na abertura comercial e financeira,

\footnotetext{
${ }^{33}$ Refiro-me à discussão e categorização de otimismo e pessimismo sanitários, tal como propostas por Doroty Porter (1994). A autora associa à concepção histórica de George Rosen a primeira categoria em que se identifica uma afinidade entre processo de industrialização e desenvolvimento da saúde coletiva, bem como entre desenvolvimento da ciência médica e ampliação do direito à saúde. Já o pessimismo sanitário, fundamentado em teses de Michel Foucault, ressaltaria o processo de medicalização e o poder disciplinar dos médicos sobre a sociedade.
} 
na privatização de empresas públicas e na redução da intervenção do Estado na oferta de bens e serviços de natureza social.

À esfera pública caberia uma ação direcionada para os grupos sociais impossibilitados de responder às ofertas de mercado para o provimento desses serviços. No curto prazo, a proposta consistia em diminuir o déficit fiscal através da redução do gasto público. Em suma, as políticas de ajuste ocorridas na década de 1980 fizeram parte de um movimento de ajuste global, caracterizado por uma postura hierárquica das relações econômicas e políticas internacionais.

Durante o período, o Banco Mundial e o FMI passaram a formular e difundir uma agenda para a saúde baseada nesses novos princípios. 0 modo de difusão dessa agenda entre os organismos de cooperação internacional e a diversidade das respostas que vem suscitando não são suficientemente conhecidos e mereceriam análise mais aprofundada.

Contribuição importante é apresentada em estudo realizado por Costa \& Mello (1994). Segundo os autores, a partir da década de 1980, o 'paradigma da economia da saúde', baseado nos principios da focalização e da seletividade, passou a orientar a ação de organismos como o Banco Mundial, contrapondo-se ao tradicional 'paradigma da saúde pública', que orientou historicamente as iniciativas da Opas, ou a sua associação ao desenvolvimentismo na década de 1950. Entretanto, os efeitos dessa política e sua efetivação não estão dados a priori, dependendo da capacidade dos demais atores apresentarem alternativas para os problemas contemporâneos de sustentação das políticas sociais. A questão mais relevante, para os propósitos desta seção, consiste em identificar a possibilidade de dissensos e respostas diferenciadas às propostas de ajuste neoliberal para a área de saúde.

Historicamente a 0PAs legitimou-se como organismo de cooperação internacional, a partir da criação de diversos fóruns, nos quais era possível o estabelecimento de uma agenda de saúde pública comum para os países latino-americanos, em que pesem controvérsias científicas e políticas. 
As Conferências Pan-Americanas de Saúde e o Boletim cumpriram papel importante para a consecução de tais objetivos e influenciaram, pode-se dizer, a gestação de uma cultura institucional e profissional. Não seria demasiado sugerir que, em muitos momentos da história desta instituição, interesses de grupos profissionais e de comunidades científicas tiveram um peso tão relevante quanto os interesses nacionais dos países que a integram. Isso apenas indica a complexidade do tema da formação e difusão de agendas para a área de saúde, o que não pode ser adequadamente avaliado, levandose em conta apenas as propostas de ajuste econômico. 0 que mencionei como proposta dissonante está relacionado à importância atribuída por este organismo a princípios como equidade e universalidade de acesso a bens e serviços, que seriam constitutivos do paradigma da saúde coletiva.

É a partir dessa compreensão que pode ser mais bem avaliado o documento "A saúde pública nas Américas", em processo de discussão pelos países do continente (documento da 126ª sessão do Comitê Executivo, 1994). Decorreu de visão particular sobre a reforma setorial da saúde nos países americanos e da proposição de uma metodologia de acompanhamento das 'funções essenciais de saúde pública' em sua relação com o fortalecimento da função dirigente da autoridade sanitária. Seu ponto de partida pode ser identificado na crítica à concentração dos processos de reforma do setor saúde nas mudanças estruturais, financeiras e organizacionais dos sistemas de saúde e de ajustes na prestação dos serviços aos indivíduos. Ressaltase, entre outros aspectos, a pequena atenção dedicada à saúde pública. Entre os objetivos da iniciativa "A saúde pública nas Américas", destacam-se: promover conceito comum de saúde pública e suas funções essenciais nas Américas; criar metodologia para avaliação; propor um plano continental de ação para fortalecer a infra-estrutura e melhorar a prática de saúde pública.

Outra questão importante consiste na afinidade entre algumas propostas, como, por exemplo, a redefinição do papel do Estado e a descentralização política. A redefinição do papel do Estado vem favorecendo o processo de descentralização, tendo por base a defesa de participação 
mais ativa e direta de instâncias estaduais e municipais no processo decisório e na gestão de responsabilidades até então exclusivas do poder central. A redemocratização, iniciada na década de 1980 na América Latina, impulsionou o processo de descentralização política, fiscal e administrativa e de 'restauração' do federalismo, juntamente com o compromisso de melhorar os serviços públicos e de promover a distribuição de renda.

0 debate sobre descentralização no âmbito da OPAS resultou na deliberação pelo Conselho Diretor, em 1988, sobre a necessidade de rápida transformação nos sistemas de saúde por meio de estratégia para o desenvolvimento e consolidação dos Sistemas Locais de Saúde (SıLos). Esse projeto tinha por finalidade descentralizar os serviços de prestação primária de saúde com o intuito de alcançar a meta de "saúde para todos", prevendo o aumento da cobertura e a ampliação dos serviços que estavam até então desativados. A OpAs promoveu e apoiou os esforços dos países em criar redes de sistemas locais de saúde que pudessem responder às necessidades específicas das comunidades. Propôs, então, um sistema descentralizado de serviços com três níveis de atenção e recursos que atuassem conjuntamente: 1) nível básico, local ou primário, responsável pelos serviços de saúde da comunidade e pela ampliação da cobertura; 2) nível intermediário ou regional, no qual inclui serviços integrados de prevenção, cura e reabilitação em estabelecimentos hospitalares; 3) nível nacional, que compreende centros médicos e institutos de investigação científica altamente desenvolvidos (BosP, v. 109, n. 5 e 6, nov. e dez. 1990; Opas, 1992).

No caso específico do Brasil, a federação, como instituição, e, no terreno próprio das políticas sociais, o gasto social como política pública, passaram por profundas transformações trazidas tanto pelo compromisso assumido com a redemocratização como pelo novo paradigma econômico. A proposta descentralizadora foi reforçada pela crítica ao padrão de proteção social construído pelos governos autoritários: hipercentralizado, institucionalmente fragmentado e iníquo do ponto de vista dos serviços e benefícios distribuídos. 0 objetivo era a correção das distorções do sistema 
de proteção social, de forma a torná-lo um instrumento de redução das desigualdades sociais. A descentralização foi vista como instrumento de universalização do acesso e do aumento do controle dos beneficiários sobre os serviços sociais. À exceção da área de previdência, nas demais áreas da política social brasileira, como educação fundamental, assistência social, saúde, saneamento e habitação popular, foram implantados programas que objetivavam transferir paulatinamente um conjunto significativo de atribuições de gestão federal aos níveis estadual e municipal de governo.

Muitos trabalhos vêm mostrando que, embora devagar e de forma inconstante, as esferas subnacionais estão ampliando suas atribuições em certas áreas. ${ }^{34} 0$ aumento do papel dos governos municipais na provisão de serviços sociais pode ser visto na Tabela 1.

Tabela 1 - Despesa social por nível de governo

\begin{tabular}{lrrrrrrc}
\hline & 1980 & 1985 & 1992 & 1994 & 1995 & 1996 & Média (1994-96) \\
\hline Gasto social & 100 & 100 & 100 & 100 & 100 & 100 & 100 \\
Federal & 66 & 62 & 57 & 60 & 59 & 57 & 59 \\
Estadual & 24 & 25 & 26 & 23 & 24 & 23 & 24 \\
Municipal & 11 & 13 & 16 & 16 & 17 & 19 & 18 \\
\hline
\end{tabular}

Fonte: Oliveira (1999).

Apesar de o governo federal permanecer como o principal investidor, 65\% dos seus recursos para a área social são gastos com o sistema previdenciário, $17 \%$ com saúde e $8,5 \%$ com educação. Os estados investem a metade dos recursos da área social em educação e os municípios em habitação e urbanismo, seguido de transporte e saneamento (Draibe, 1999). Dados das contas subnacionais entre 1986 e 1995 mostram que, antes mesmo da Constituição de 1988, as capitais estaduais vêm priorizando gastos na área social. No entanto, o papel do governo municipal tem aumentado, não só devido ao maior volume de recursos investidos, mas também devido à redução relativa dos gastos federais. Esses dados também mostram que as

${ }^{34}$ Rezende (1997) e Almeida (1996). 
capitais estaduais estão desenvolvendo maiores esforços do que os estados para manter seus investimentos na área social e que existe uma grande tensão entre despesas com serviços sociais e pagamento de juros da dívida.

Embora houvesse uma inclinação generalizada pela descentralização, não existiu, porém, uma verdadeira política nesse sentido que orientasse a reforma das diferentes políticas sociais. De quatro áreas - educação, saúde, assistência social e habitação - a de saúde foi a única em que a reforma resultou de uma política deliberada e radical de descentralização, definida no âmbito federal, envolvendo Executivo e Legislativo. A descentralização da política de saúde foi sendo desenhada desde 1983, até ganhar feição definitiva em 1988, com a criação do SUS, completada pela Lei Orgânica de Saúde em 1990. A criação do SUS é geralmente entendida como a mais bem-sucedida reforma da área social empreendida sob o novo regime democrático. Ainda que a implantação do novo sistema esteja longe de se completar e muitos sejam seus impasses; no estágio atual, já significa uma transformação profunda do sistema público de saúde. A reforma promoveu a racionalização dos serviços de saúde por meio de: a) integração das redes federal, estadual e municipal, e municipalização do atendimento primário; b) definição das fontes de financiamento; c) estabelecimento de funções para as instâncias de governo; d) criação de mecanismos automáticos de transferências de recursos no interior da rede pública e para o setor privado.

Importante componente do SUS consiste no estabelecimento de mecanismos decisórios que fortaleçam instâncias colegiadas e a representação dos diferentes atores envolvidos no sistema de saúde. Ademais, a proposta de reforma foi elaborada a partir de intensa mobilização social e complexo processo de negociação política que envolveu lideranças da área de saúde, parlamentares e poder executivo. A experiência do SUS tem sido objeto de teses acadêmicas e inúmeros projetos de avaliação de políticas públicas, particularmente em nível local, o que certamente contribuirá para a redefinição de estratégias e para a sua consolidação. 


\section{A Opas e a saúde nas Américas}

0 papel da Opas na elaboração e difusão de idéias e projetos de saúde coletiva foi acentuado em vários momentos e continua a influenciar países como o Brasil. Uma das idéias-força na atividade atual da organização é a meta de "saúde para todos", que, desde a década de 1980, vem sendo abordada pela organização à luz da definição de estratégias adequadas para torná-la realidade.

Esse foi o enfoque da XXI Conferência Sanitária Pan-Americana realizada em Washington, em setembro de 1982, onde se elegeu Carlyle Guerra Macedo, diretor geral da Opas. Nesse fórum, aprovou-se o Plano de Ação para a Instrumentação de Estratégia de Saúde para Todos no Ano 2000. Nas conferências que se seguiram e demais fóruns de discussão e deliberação, persistiu a preocupação em ir além da retórica da saúde como direito e definir objetivos que implicassem mudanças na qualidade de vida das populações. Nos primeiros momentos da gestão, promoveu-se a reorientação da OPAS, com base no conceito de administração do conhecimento, o que implicava atribuir prioridade a ações que facilitassem o acesso a conhecimento por parte dos países e sua adequação às realidades nacionais e locais específicas. ${ }^{35}$ Outra ação relevante consistiu na proposta de atribuir à saúde 0 papel de uma ponte para o estabelecimento da paz, motivada principalmente pelos conflitos e guerras civis que ocorriam na América Central. ${ }^{36}$

Durante esse período, verificou-se também a defesa de abordagens interdisciplinares sobre a saúde, com o incentivo à apropriação de conhecimentos originários das ciências sociais. As reuniões de Cuenca sobre ciências sociais e saúde inserem-se nesse objetivo. Realizadas em 1983 e 1988, aprofundaram as discussões que, desde a década de 1970, eram organizadas a partir do projeto coordenado por Juan César Garcia (Nunes, 1985).

\footnotetext{
${ }_{35}$ Depoimento de Carlyle Guerra de Macedo, concedido a Nísia Trindade Lima para o Acervo da Casa de Oswaldo Cruz, 2002.

${ }^{36}$ Depoimentos de Carlyle Guerra de Macedo e Jacobo Finkelman, concedidos a Nísia Trindade Lima para o Acervo da Casa de Oswaldo Cruz, 2002.
} 
Novo marco para a atuação da OpAs ocorreria na XXII Conferência Pan-Americana com a aprovação do documento Orientação e Prioridades Programáticas para a OPS no Quadriênio 1987-1990. Destacava-se a necessidade, suscitada pelos problemas da saúde e do desenvolvimento da região, de transformar os serviços de saúde dos países. Essa transformação abarcava três áreas inter-relacionadas: o desenvolvimento da infra-estrutura dos serviços de saúde, a atenção primária, a atenção aos problemas prioritários de saúde dos grupos vulneráveis, mediante a execução de programas específicos por intermédio do sistema de serviços de saúde e a administração do conhecimento. Em 1988, seria completado com a proposta dos Sistemas Locais de Saúde (Sitos).

Durante os vinte anos a que se fez referência é possível identificar três características centrais nas atividades da OPAs: a ampliação da agenda tradicional de saúde pública, com a inclusão de temas como violência, destacando-se a realização da primeira conferência interamericana sobre este tema em 1994; a definição de uma meta que, no âmbito das doenças transmissíveis, demonstrasse os resultados positivos da saúde pública e da capacidade da mobilização social - a erradicação da poliomielite -; e a proposição de uma nova agenda para a saúde pública na América Latina, que oferecesse rumos alternativos à reforma da saúde, tal como se propõe com o documento A Saúde nas Américas.

Quando se observa a ampliação da agenda tradicional, tão bem sintetizada na epígrafe desta seção, pode-se verificar essa ampliação também no que se refere às doenças crônico-degenerativas, cuja importância epidemiológica é cada vez mais evidente. Devem-se também considerar não apenas novos temas, mas também novas abordagens para problemas há muito incluídos no campo da saúde pública, como é o caso da saúde mental, objeto de artigos, discussões e deliberações específicas da OpAs quanto às necessárias transformações na atenção psiquiătrica (OPAs, 1992; Macedo, 1977). 
Se, nas origens da OPAs, as doenças transmissíveis consistiam na principal motivação para a cooperação internacional de saúde, no início do século XXI permanecem como importante desafio. Os resultados alcançados em relação a algumas doenças imunopreviníveis, com destaque para a erradicação da varíola e da poliomielite, não encontram paralelo no que se refere a outras doenças. No caso da epidemia de Aids, ações importantes têm sido realizadas a partir do estabelecimento, pela 0MS, do Programa Global contra a Aids. Além da malária, que permanece como grave problema de saúde, novas questões epidemiológicas têm se colocado no que se refere à doença mais presente na história da OPAS - a febre amarela. Note-se inclusive que artigos sobre a erradicação do Aedes aegypti são muito freqüentes nos Boletins desde o seu primeiro número, publicado em 1922, assim como propostas de ações cooperativas da OpAs no combate à dengue no continente.

Em relação ao Brasil, muitos autores têm realçado as peculiaridades de seu processo de transição epidemiológica, caracterizada pela coexistência de doenças infecciosas e crônico-degenerativas, em que pese o declínio das primeiras entre as causas de mortalidade. (Waldman; Silva \& Monteiro, 2000; Sabroza; Kawa, \& Campos, 1995). Verificou-se, a partir da década de 1980, a reintrodução do cólera e do dengue, o recrudescimento da malária e a continuidade de níveis elevados de tuberculose, hanseníase e leishmaniose.

A erradicação da poliomielite nas Américas, declarada em 1994, suscita questões pertinentes para a presente reflexão. Referi-me anteriormente à importância da experiência brasileira devido ao conhecimento acumulado nas campanhas de erradicação da varíola e do plano nacional de controle da poliomielite. A campanha de erradicação da transmissão autóctone de poliovírus selvagens nas Américas, lançada em 1985, como ação conjunta da OPAs, UNICEF, Agência para o Desenvolvimento Internacional dos EUA e Rotary Internacional, revelou o grande potencial de mobilização das sociedades do continente americano para responder a ações coordenadas de saúde pública. Uma das contribuições importantes consistiu na revisão da oposição, a que já se fez referência, entre as campanhas de imunização e 
a estruturação dos serviços de assistência à saúde. Como observou Carlyle Guerra de Macedo:

Procuramos também inserir as campanhas de imunização em geral, particularmente as de pólio, no funcionamento dos serviços de saúde, inclusive como estímulo ao desenvolvimento da prestação de serviços de saúde. Um estudo inteiramente independente da OpAs demonstrou essa possibilidade. ${ }^{37}$

Nas áreas de imunização e produção de medicamentos, um importante problema enfrentado pelos países latino-americanos encontra-se nos obstáculos ao desenvolvimento tecnológico relacionado à produção de insumos para a saúde. Pode-se mesmo afirmar a existência de um consenso entre os estudiosos de política científica e tecnológica e os que se propõem a desenvolver tecnologias voltadas para a produção de vacinas e fármacos sobre a ausência de políticas públicas adequadas para 0 desenvolvimento desse setor.

Uma das áreas mais importantes em que a Opas atuou durante esse período foi a de saneamento e, numa perspectiva mais ampla, a de saúde ambiental. Observam-se a consolidação da engenharia sanitária no curso da história do organismo e várias iniciativas de cooperação técnica, nessa área e na de saúde ambiental, como o apoio à criação de instituições locais. 0 período de 1981 a 1990 foi considerado pela OPAS/OMS a "Década internacional de água potável e saneamento", estabelecendo-se prioridade para a realização das metas de saneamento e saúde ambiental na América Latina. ${ }^{38}$

A diversidade e a complexidade inerentes à abordagem da saúde pública nas duas últimas décadas talvez sejam mais adequadamente resumidas com a palavra desafio: desafios relacionados tanto aos novos conhecimentos no campo biomédico e social como às possibilidades de desenvolvi-

\footnotetext{
${ }^{37}$ Depoimento de Carlyle Guerra de Macedo, concedido a Nísia Trindade Lima para o Acervo da Casa de Oswaldo Cruz, 2002.

${ }^{38}$ Sobre a política de saneamento no Brasil, ver o estudo de Nilson Rosário Costa (1998).
} 
mento científico e tecnológico no campo da saúde, assim como relacionados à promoção da equiidade e de uma agenda alternativa para a Saúde das Américas. Alguns desafios parecem muito próximos àqueles enfrentados pelos que propuseram a criação da Oficina Sanitária Internacional em 1902. Outros, mal podem ser identificados no tempo presente. De todo modo, sempre será possível inovar na forma de abordá-los. 


\title{
Contribuições
}

\section{Centro Pan-Americano de Febre Aftosa}

\author{
Eduardo Correa Melo
}

A disseminação da febre aftosa na primeira metade do século XX, em todo o território da América do Sul, e os programas exitosos de erradicação da doença na América do Norte, incentivaram os governos da região a estabelecer, em 1951, o Centro Pan-Americano de Febre Aftosa (Panafrosa), no Rio de Janeiro, em uma primeira etapa no âmbito da Organização dos Estados Americanos (OEA), para, posteriormente, passar a fazer parte permanente de um programa regular da Organização Pan-Americana da Saúde (OPAS).

A criação da Panaftosa inicia, na região, um processo continuado de interação entre a investigação, o planejamento e a avaliação de estratégias para o combate à enfermidade, que desembocam na implantação, nas décadas de 1960 e 1970, de programas e projetos de controle e erradicação da febre aftosa, com a cooperação técnica da Panaftosa/Opas/OMS, e o apoio financeiro de Banco Interamericano de Desenvolvimento. Em 1965, o Brasil iniciou seu programa, no estado do Rio Grande do Sul.

Nesse contexto, produziu-se substancial avanço em termos de diagnóstico virológico e serológico da febre aftosa, que foi transferido aos laboratórios nacionais dos países, tarefa que continua até hoje.

Este desenvolvimento permitiu passar de cerca de $30 \%$ de rebanhos sob controle, no início da década de 1960, para 85\% na década de 1980, época em que o 
Chile, em 1981, foi o primeiro país da região a ser reconhecido como livre de febre aftosa sem vacinação, condição que, em 1994, seria alcançada pelo Uruguai.

Cabe destacar a criação, em 1972, da Comissão Sul-Americana de Luta contra a Febre Aftosa (Cosalfa), da qual Panaftosa é a Secretaria ex officio, e que constitui o mais importante fórum dos dirigentes da área de saúde animal dos países da região.

No ano seguinte, o Centro, em coordenação com os países, inicia a aplicação do Sistema Continental de Informação e Vigilância de Enfermidades Vesiculares, que, utilizando um esquema de quadrantes geográficos, permitiu acesso oportuno ao conhecimento da situação epidemiológica das doenças vesiculares nas Américas.

Ao final da década de 1970, o Panaftosa liderou o desenvolvimento e a validação de uma ferramenta que teve papel importante para o êxito dos programas de controle e erradicação da enfermidade na região - a vacina antiaftosa com adjuvante oleoso. A isso acrescentaram-se a caracterização e a delimitação geográfica dos diversos ecossistemas de febre aftosa, segundo situações de risco originadas pelas estruturas produtivas e de comercialização pecuária imperantes, bem como estratégias alternativas de controle, disseminação e erradicação da doença.

Durante todos estes anos, o Centro contribuiu de forma importante não só para a melhoria do diagnóstico virológico e serológico de febre aftosa na região, como também para o fortalecimento dos sistemas de controle de vacinas no continente.

Ao final da década de 1980, Panaftosa, em estreita colaboração com os países, desenvolveu e implementou a aplicação do Plano Hemisférico de Erradicação da Febre Aftosa (PHEFA), o que considerou, além dos avanços já assinalados, a ativa participação da comunidade e de todos os agentes atuantes no tema, no marco de uma política de descentralização e trabalho intersetorial. O Plano Hemisférico constitui, desde 1988, marco para o desenvolvimento e a aplicação dos programas nacionais de prevenção, controle e erradicação da febre aftosa no continente.

Como resultado de todo este processo, os territórios da América do Norte, da América Central e do Caribe mantêm-se livres da doença sem vacinação e avançou-se, de forma decisiva e consistente, na erradicação da enfermidade na América do Sul, o que se pode apreciar nos seguintes indicadores:

- em 1988, 11,3\% da superfície da América do Sul estava livre da febre aftosa, enquanto, em 2002 , tem-se $35,7 \%$ da área livre da doença, com e sem vacinação; 
- em 1988, cerca de 171 mil rebanhos bovinos estavam nessas áreas livres de febre aftosa, hoje, mais de 1,8 milhões de rebanhos estão nessa condição;

- em 1988, havia 4,88 milhões de bovinos nessas áreas livres, hoje, há mais de 144,1 milhões de cabeças nessas áreas.

Cabe destacar que, desse total, cerca de 125 milhões de bovinos encontramse nas áreas livres com vacinação do Brasil.

Finalmente, é importante mencionar que, desde 1998, Panaftosa, por decisão dos corpos diretivos da OPAS, tomou a responsabilidade da Cooperação Técnica em matéria de Zoonoses.

\title{
Bireme: 35 anos rumo ao acesso equitativo à informação em ciências da saúde
}

\author{
Abel Laerte Packer
}

Em 2002, quando se comemoram os cem anos da Organização Pan-Americana da Saúde (OPAS), a Bireme cumpre 35 anos de atividade como centro especializado em informação científica e técnica em saúde para a região da América Latina e Caribe. Estabelecida no Brasil em 1967, com o nome de Biblioteca Regional de Medicina (que originou a sigla BIREME), atendeu desde o princípio à demanda crescente de literatura científica atualizada por parte dos sistemas nacionais de saúde e das comunidades de pesquisadores, profissionais e estudantes. Posteriormente, em 1982, passou a chamar-se Centro Latino-Americano e do Caribe de Informação em Ciências da Saúde, para melhor expressar as suas funções orientadas ao fortalecimento e ampliação do fluxo de informação científica e técnica em saúde em toda a região.

0 trabalho em rede, com base na descentralização, no desenvolvimento de capacidades locais, no compartilhamento de recursos de informação, no desenvolvimento de produtos e serviços cooperativos e na elaboração de metodologias comuns, 
foi sempre o fundamento do trabalho de cooperação técnica da BiReme. É assim que, ao longo destes 35 anos, o Centro se consolida como um modelo internacional. Em particular, o modelo privilegia a capacitação dos profissionais de informação em nível gerencial e técnico para a adoção de paradigmas de informação e comunicação que melhor atendam as necessidades locais.

No início dos anos 1980, a BiReme inicia a operação da base de dados LiLAcs (Literatura da América Latina e do Caribe em Ciências da Saúde), com o objetivo de estabelecer o controle bibliográfico, indexar, dar visibilidade e accesso à literatura científica em saúde publicada nos países da América Latina e Caribe. Dessa forma, a LiLAcs complementa a literatura publicada nos países desenvolvidos. Esse trabalho de indexação é compartilhado com instituições nacionais dos países através de um sistema regional.

A disseminação das fontes de informação bibliográficas ganhou um grande impulso em 1987, quando a BIREME introduziu a tecnologia de CD-ROM em mais de 250 bibliotecas da América Latina para a distribuição de bases de dados bibliográficos, entre elas Lliacs e Medune. Pela primeira vez na história, a maioria dos países da região teve acesso local e barato às bases de dados da literatura internacional e regional.

Com o surgimento e consolidação da Internet como meio predominante de informação e comunicação, o modelo de cooperação técnica da BIREME evoluiu, a partir de 1998, para a construção e desenvolvimento da Biblioteca Virtual em Saúde (BVS), como espaço comum de convergência do trabalho cooperativo de produtores, intermediários e usuários de informação. A BVS promove o desenvolvimento de uma rede de fontes de informação científica e técnica com accesso universal na Internet. Pela primeira vez abre-se a possibilidade real de accesso eqüitativo à informação em saúde.

Hoje, todos os países da América Latina e Caribe participam direta ou indiretamente dos produtos e serviços cooperativos promovidos pela BVS, envolvendo mais de mil instituições em mais de trinta países.

A BVS organiza a informação em uma estrutura que integra e interconecta bases de dados referenciais, diretórios de especialistas, eventos e instituições, catálogo de recursos de informação disponíveis na Internet, coleções de textos completos com destaque para a coleção SciElo de revistas científicas, serviços de disseminação seletiva de informação, fontes de informação de apoio à educação e à tomada de decisão, notícias, listas de discussão e apoio a comunidades virtuais. A BVS conta com um 
vocabulário controlado de descritores em ciências da saúde que é utilizado para a indexação das fontes de informação nos idiomas português, espanhol e inglês. 0 espaço da BVS constitui, portanto, uma rede dinâmica de fontes de informação descentralizada a partir da qual se podem recuperar e extrair informação e conhecimento para subsidiar os processos de decisão em saúde.

0 lançamento da BVS Saúde Pública Brasil, em março de 2002 representa um marco histórico na democratização do accesso à informação científica e técnica em saúde no Sistema Único de Saúde (SUS). O projeto, financiado pelo Ministério da Saúde e pela OPAs, conta com a participação ativa das principais instituições nacionais de saúde pública na promoção do uso de informação e conhecimento atualizados na gestão da saúde pública no Brasil.

A Bireme se destaca nacional e internacionalmente no desenvolvimento de soluções inovadoras em metodologias e tecnologias de informação que acompanham o avanço internacional, mas se adaptam às condições socioeconômicas da região e contribuem para que nossas instituições dominem meios altamente qualificados e eficientes de tratamento e disseminação de informação.

Vale ressaltar que várias instituições promoveram a criação da BiReme, destacando-se a Federação Pan-Americana de Associações de Escolas de Medicina (Fepafem), a National Library of Medicine dos Estados Unidos (NLM), a Universidade Federal de São Paulo (Unjfesp/EPM) e a Opas. Um convênio de cooperação entre a OPAs, o Ministério da Saúde, o Ministério da Educação, a Secretaria da Saúde do Estado de São Paulo e a UNIFEsP/EPM a mantém desde 1967. Essas instituições orientam e acompanham o trabalho e o desempenho do Centro por meio de um comitê consultivo nacional.

A história da Bireme no Brasil e nos demais países da América Latina e Caribe, construída com o trabalho cooperativo de milhares de instituições e profissionais, reafirma e enaltece o papel da cooperação técnica da OPAs em prol do acceso equitativo à informação em saúde. ${ }^{39}$

\footnotetext{
${ }^{39}$ Para saber mais: http://www.bireme.br e http://www.saudepublica.bvs.br.
} 


\section{Referências bibliográficas}

ACKERKNECHT, E. H. Anticontagionism between 1821 and 1867. Bulletin of History of Medicine, XXII (5): 562-593, 1948.

ALMEIDA, H. T. M. Federalismo e políticas sociais. In: AFFONSO, R. B. \& SILVA, P. L. (Orgs.) Descentralização e Políticas Sociais. São Paulo: Fundap/Unesp, 1996.

AROUCA, A. S. S. O Dilema Preventivista: contribuição para a compreensão e crítica da medicina preventiva, 1975. Tese de Doutorado, Campinas: Faculdade de Medicina, Universidade de Campinas.

BARBOSA, R. Oswaldo Cruz. Revista do Brasil, ano II, 5 (19): 271-321, 1917.

BARRETO, J. B. Tratado de Higiene: saneamento, bigiene. Rio de Janeiro: Imprensa Nacional, 1942.

BENCHIMOL, J. L. Manguinbos do Sonbo a Vida: a ciência na Belle Époque. Rio de Janeiro: Fundação Oswaldo Cruz, 1990a.

BENCHIMOL, J. L. Pereira Passos: um Haussmann tropical. Rio de Janeiro: Secretaria Municipal de Cultura, Turismo e Esporte, 1990b. (Coleção Biblioteca Carioca).

BENCHIMOL, J. L. Dos Micróbios aos Mosquitos: febre amarela no Rio de Janeiro (1880-1903). Rio de Janeiro: Editora da Universidade Federal Fluminense/Editora Fiocruz, 1999.

BENCHIMOL, J. L. Febre Amarela: a doença e a vacina, uma bistória inacabada. Rio de Janeiro: Bio-Manguinhos/Editora Fiocruz, 2001.

BENCHIMOL, J. L. \& TEIXEIRA, L. A. Cobras, Lagartos \& Outros Bichos: uma história comparada dos Institutos Oswaldo Cruz e Butantan. Rio de Janeiro: Editora UFRJ/Casa de Oswaldo Cruz, 1993.

BRAGA, E. O Pensamento de Ernani Braga. Rio de Janeiro: PEC/Ensp, 1984.

BRIGGS, A. Cholera and society in the nineteenth century. Past and Present, 19: 76-96, 1961.

BRITTO, N. Oswaldo Cruz: a construção de um mito da ciência brasileira. Rio de Janeiro: Editora Fiocruz, 1995.

BUSTAMANTE, M. Cincuentenario del Boletin de la Oficina Sanitaria Panamericana, 19221972. Boletin de la Oficina Sanitaria Panamericana, 72 (5): 375-396, 1972.

CAMPOS, A. L. V. International Health Policies in Brazil: the Serviço Especial de Saúde Pública - 1942-1960, 1997. Tese de Doutorado, Austin: Universidade do Texas.

CAMPOS, A. L. V. Políticas internacionais de saúde na era Vargas: o serviço especial de saúde pública. In: GOMES, A. C. (Org.) Capanema: o ministro e seu ministério. Rio de Janeiro: Fundação Getúlio Vargas, 2000.

CANDAU, M. \& BRAGA, E. Novos rumos para a saúde pública rural. In: BUSS, P. (Org.) $O$ Pensamento de Ernani Braga. Rio de Janeiro: PEC/Ensp, 1984.

CARRARA, S. Tributo a Vênus: a luta contra a sifilis no Brasil-da passagem do século aos anos 40. Rio de Janeiro: Editora Fiocruz, 1996.

CARVALHO, J. M. Brasil, naciones imaginadas. In: ANNINO, A.; LEIVA, L. C. \& GUERRA, F. (0rgs.) De los Imperios a las Naciones. Zaragoza, Intercaja: Ibero-América, 1994.

CASTRO SANTOS, L. A. de. o pensamento sanitarista na Primeira República: uma ideologia de construção da nacionalidade. Dados - Revista de Ciências Sociais, 28: 193-210, 1985. 
CASTRO SANTOS, L. A. de. Power, Ideology and Public Health in Brazil (1889-1930), 1987. Tese de Doutorado, Cambridge: Harvard University.

CASTRO SANTOS, L. A. de. A fundação Rockefeller e o estado nacional: história e política de uma missão médica e sanitária no Brasil. Revista Brasileira de Estudos da População, 6 (1): 105-110, jan.jun., 1989.

CHALHOUB, S. Cidades Febris. São Paulo: Companhia das Letras, 1996.

COSTA, N. R. Políticas Públicas, Justiça Distributiva e Inovação: saúde e saneamento na agenda social. São Paulo: Hucitec, 1998.

COSTA, N. R. \& MELO, M. A. Desenvolvimento sustentável, ajuste estrutural e política social: as estratégias da OMS/OPS e do Banco Mundial para a atenção à saúde. Planejamento e Políticas Pública - Ipea, 11, 1994.

COURTNEY, K. Escritório da Zona V da Repartição Sanitária Pan-Americana. Bosp, ano 33, XXXVI (5): 503-516, 1954.

CUETO, M. Introducion. In: CUETO, M. (Org.) Salud, Cultura y Sociedad en América Latina: nuevas perspectivas bistóricas. Lima: Instituto de Estudos Peruanos/Opas, 1996a.

CUETO, M. Los ciclos de la erradicación: la fundación Rockefeller y la salud pública latinoamericana, 1918-1940. In: CUETO, M. (Org.) Salud, Cultura y Sociedad en América Latina: nuevas perspectivas históricas. Lima: Instituto de Estudos Peruanos/Opas, 1996b.

DE SWAAN, A. In Care of the State: bealth care, education and welfare in Europe in the modern era. Cambridge: Polity Press, 1990.

DOUGLAS, M. Pureza e Perigo. Tradução de Mônica Siqueira Leite de Barros e Zilda Pinto. São Paulo: Perspectiva, 1976.

DRAIBE, S. Brasil, anos 90: as politicas sociais no marco das reformas estruturais. São Paulo: Ed. USP, 1999.

DUFFY, J. The Sanitarians. Urbana/Chicago: Board of Trustees of the University of Illinois, 1990.

ELIAS, N. O Processo Civilizador: formação do Estado e civilização. Rio de Janeiro: Jorge Zahar, 1990.

ESCOREL, S. Reviravolta na Saúde: origem e articulação do movimento sanitário. Rio de Janeiro: Editora Fiocruz, 1998.

FARIA, L. R. A Fase Pioneira da Reforma Sanitária no Brasil: a atuação da Fundação Rockefeller (1915-1930), 1994. Dissertação de Mestrado, Rio de Janeiro: Instituto de Medicina Social, Universidade do Estado do Rio de Janeiro (Uerj).

FEE, E. Disease and Discovery: a bistory of the Jobn Hopkins School of Hygiene and Public Health (1916-1939). Baltimore/Londres: The John Hopkins University Press, 1987.

FERREIRA, L. 0. O Nascimento de uma Instituição Científica: o periódico médico brasileiro da primeira metade do século XIX, 1996. Tese de Doutorado, São Paulo: Universidade de São Paulo (USP).

FONSECA, C. 0. As propostas do Sesp para educação em saúde na década de 1950: uma concepção de saúde e sociedade. Cadernos da Casa de Oswaldo Cruz, v. 1, 1989.

FONSECA, C. 0. As campanhas sanitárias e o Ministério da Saúde (1953-1990). In: BENCHIMOl, J. (Coord.) Febre Amarela: a doença e a vacina, uma bistória inacabada. Rio de Janeiro: Bio-Manguinhos/Editora Fiocruz, 2001. 
GADELHA, P. História de Doenças: ponto de encontros e de dispersões, 1995. Tese de Doutorado, Rio de Janeiro: Ensp/Fiocruz.

HOCHMAN, G. A Era do Saneamento: as bases da politica de saúde pública no Brasil. São Paulo: Hucitec/Anpocs, 1998.

HOCHMAN, G. \& FONSECA, C. A I Conferência Nacional de Saúde: reformas, políticas e saúde em debate no Estado Novo. In: GOMES, A. C. (Org.) Capanema: o ministro e seu ministério. Rio de Janeiro: Fundação Getúlio Vargas, 2000.

LABRA, E. 1955-1964: o sanitarismo desenvolvimentista. In: TEIXEIRA, S. F. et al. (Coords.) Antecedentes da Reforma Sanitária: textos de apoio. Rio de Janeiro: Pec/Ensp, 1988.

LATOUR, B. Les Microbes: guerre et paix suivi de irréductions. Paris: A. M. Metalie, 1984.

LIMA, N. T. Um Sertão Chamado Brasil: intelectuais e representações geográficas da identidade nacional. Rio de Janeiro: Instituto Universitário de Pesquisas do Rio de Janeiro/ Editora Revan, 1999.

LIMA, N. T. Informe sobre pestes. Inteligência, ano II, 9: 10-20, nov. 1999/abr. 2000.

LIMA, N. T. \& BRITTO, N. Salud y nación: propuesta para el saneamento rural - un estudio de la revista Saúde (1918-1919). In: CUETO, M. (Org.) Salud, Cultura y Sociedad en América Latina: nuevas perspectivas bistóricas. Lima: Instituto de Estudos Peruanos/ Opas, 1996.

LIMA, N. T. \& HOCHMAN, G. Condenado pela raça, absolvido pela medicina: o Brasil descoberto pelo movimento sanitarista da Primeira República. In: MAIO, M. C. \& SANTOS, R. V. (Orgs.) Raça, Ciência e Sociedade. Rio de Janeiro: Fiocruz/Centro Cultural Banco do Brasil, 1996.

LUZ, M. Instituições Médicas no Brasil: instituição e estratégia de begemonia. Rio de Janeiro: Graal, 1979.

MACED0, C. G. Notas para uma bistória recente da saúde pública na América Latina. Brasilia: Organização Pan-Americana de Saúde - Representação no Brasil, 1977.

MACHADO, R. et al. Danação da Norma: medicina social e constituição da psiquiatria no Brasil. Rio de Janeiro: Graal, 1978.

MARINHO, M. G. S. M. C. Norte-americanos no Brasil: uma bistória da Fundação Rockefeller na Universidade de São Paulo (1934-1952). Campinas: Editores Associados/São Paulo, Universidade de São Francisco, 2001.

MOLL, A. A. The Pan American Sanitary Bureau: its origin, development, and achievements a review of inter-american cooperation in public health, medicine, and allied fields. Boletin de la Oficina Sanitaria Panamericana, 19 (12): 1219-1234, 1940.

MOURA, G. Autonomia na Dependência: a politica externa brasileira de 1935 a 1942. Rio de Janeiro: Nova Fronteira, 1980.

MURARD, L. \& ZYLBERMAN, P. La raison de l'expert ou L'hygiène comme science sociale appliquée. Archives European of Sociology, XXVI: 58-89, 1985.

MYRDAL, G. Asian Drama. Nova Iorque: Pantheon, 1968.

NUNES, E. As Ciências Sociais em Saúde na América Latina. Brasilia: OPAS, 1985.

OLIVEIRA, F. Evolução, Determinantes e Dinâmica do Gasto Social no Brasil: 1980/1996. Brasília: Ipea, 1999. 
OLIVEIRA, L. L. A Questão Nacional na Primeira República. São Paulo: Brasiliense, 1990. ORGANIZAÇÃO PAN-AMERICANA DA SAÚDE (OPAS). Historia de la Organización Panamericana de la Salud. Washington, D. C.: Opas, 1992.

ORGANIZAÇÃO PAN-AMERICANA DA SAÚDE (OPAS)/ORGANIZAÇÃO MUNDIAL DA SAÚDE (OMS). La Repercusión del Programa Ampliado de Imunización y la Iniciativa de Erradicación de la Poliomielitis en los Sistemas de Salud en las Américas. Informe de la Comisión Taylor. Washington, D. C.: Opas, março de 1995.

NEIVA, A. \& PENNA, B. Viagem científica pelo norte da Bahia, sudeste de Pernambuco, sul do Piauí e de norte a sul de Goiânia. Memórias do Instituto Oswaldo Cruz, 8 (30): 74 $224,1916$.

PORTER, D. (Ed.) The History of Public Health and the Modern State. Amsterdã: GA Rodopi, 1994.

PORTER, R. The Great Benefit of Humanity: a medical bistory of bumanity. Nova Iorque/ Londres: W.W. Norton \& Company, 1998.

REZENDE, F. C. Descentralização, gastos públicos e preferências alocativas dos governos locais no Brasil (1980-1994). Dados - Revista de Ciências Sociais, 40 (3): 264-279, 1997.

REZENDE DE CARVALHO, M. A. \& LIMA, N. T. 0 argumento histórico nas análises de saúde coletiva. In: FLEURY, S. (0rg.) Saúde Coletiva? Questionando a onipotência do social. Rio de Janeiro: Abrasco/Relume-Dumará, 1992.

ROSANVALON, P. L'État en France. Paris: Seuil, 1990.

ROSEN, G. Da Polícia Médica à Medicina Social: ensaios sobre a bistória da assistência médica. Tradução de Ângela Louzeiro. Rio de Janeiro: Graal, 1979.

ROSEN, G. História da Saúde Pública. São Paulo: Unesp, 1994.

SABROZA, P. C.; KAWA, H. \& CAMPOS, W. S. Q. Doenças transmissíveis: ainda um desafio. In: MINAYO, M. C. S. (Org.) Os Muitos Brasis: saúde e população na década de 80 . São Paulo/Rio de Janeiro: Hucitec/Abrasco, 1995.

SANTOS, W. G. Cidadania e Justiça. Rio de Janeiro: Iuperj/Nértice, 1979.

SANTOS, W. G. A pós-revolução brasileira. In: JAGUARIBE, H. et al. (Orgs) Brasil: sociedade democrática. Rio de Janeiro: José Olympio, 1985.

SANTOS, W. G. Razões da Desordem. Rio de Janeiro: Rocco, 1993.

SOPER, F. Ata final da XI Conferência Sanitária Pan-Americana. Boletin de la Oficina Sanitaria Panamericana, 3: 193-201, ano 22, 1943.

SOPER, F. Informe sobre o Programa da Oficina Sanitária Pan-Americana. Boletim da Oficina Sanitaria Panamericana, 11: 977-997, ano 27, 1948.

SOPER, F. El Aedes Aegypti y la fiebre amarilla. Boletim da Oficina Sanitaria Panamericana, 64 (3):187-196, 1968.

SOPER, F. The memoirs of Fred Lowe Soper. Scientific Publication, 355, 1977.

SOUZA, C. Federalismo e Gasto Social no Brasil: tensões e tendências. Lua Nova - Revista de Cultura e Política, 52, 2001.

STEPAN, N. Gênese e Evolução da Ciência no Brasil. Rio de Janeiro: Artenova/Fiocruz, 1976.

STEPAN, N. The Hour of Eugenics: races, gender and nation in Latin America. Nova Iorque: University Press, 1991. 
TEIXEIRA, S. M. F. As ciências sociais em saúde no Brasil. In: NUNES, E. D. (Org.). As Ciências Sociais em Saúde na América Latina: tendências e perspectivas. Brasília: Opas/OMS, 1985.

VERONELLI, J. C. \& TESTA, A. (Orgs.). La OPS en Argentina: crónica de una relación centenaria. Buenos Aires: Opas, 2002.

WALDMAN, E. A.; SILVA, L. J. \& MONTEIRO, C. Trajetória das doenças infecciosas: da eliminação da poliomielite à reintrodução da cólera. In: MONTEIRO C. A. (Org.) Velhos e Novos Males da Saúde no Brasil. São Paulo: Editora Hucitec/Nupens/USP, 2000.

WORLD HEALTH ORGANIZATION (WHO). World Health Organization: the first term' years Genebra: WHO, 1958. 


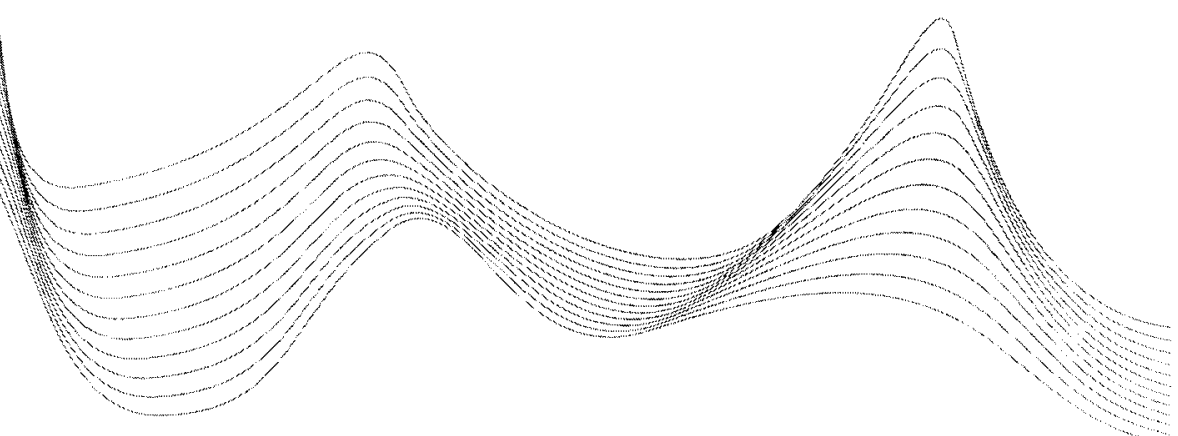

\section{2}

\section{As Condições de Saúde No BrasIL}

João Baptista Risi Junior

Roberto Passos Nogueira

Coordenadores

Adelemara Mattoso Allonzi • André Monteiro Alves Pontes • Antonio Carlos Silveira • Carlos Antonio Pontes - Celso Cardoso Simões - Eduardo Hage Carmo • Fernando Ribeiro de Barros - Germano Gerhardt Filho • Gerson Fernando Mendes Pereira • Ines Lessa - Jarbas Barbosa da Silva Junior - Laércio Joel Franco - Marceli de Oliveira Santos • Marcelo Medeiros • Marcia Regina Dias Alves • Maria Cecília de Souza Minayo - Maria Goretti P. Fonseca - Maria Helena P. de Mello Jorge • Maurício Barreto • Mauro da Rosa Elkhoury • Ruy Laurenti • Sabina Léa Davidson Gotlieb - Valeska Carvalho Figueiredo - Zuleica Portela Albuquerque 


\section{População, saúde e desenvolvimento}

A saúde emergiu como efetiva prioridade de governo no Brasil no começo do século XX, com a implantação da economia exportadora de café, na região Sudeste. A melhoria das condições sanitárias, entendida então como dependente basicamente do controle das endemias e do saneamento dos portos e do meio urbano, tornou-se uma efetiva política de Estado, embora essas ações estivessem bastante concentradas no eixo agrário-exportador e administrativo formado pelos estados do Rio de Janeiro e São Paulo.

A economia exportadora de café compunha-se de dois segmentos: um núcleo agrário - produtor de café e de alimentos - e um núcleo urbano - que abrangia as atividades de financiamento, comercialização, transportes, administração e indústrias. Com importância crescente desde as primeiras décadas do século XIX, a exportação de café, entre 1924 e 1928, chegou a representar $72,5 \%$ das receitas de exportação do Brasil, superando em muito o valor de exportação de outros produtos tradicionais, tais como 0 algodão, a borracha e as peles e couros. Esse período corresponde ao da formação de um verdadeiro mercado de trabalho no Brasil, envolvendo uma massa considerável de trabalhadores, com integração produtiva entre os setores urbano e rural. Para a formação desse mercado, houve uma contribuição fundamental dos imigrantes de países estrangeiros, que constituíam uma força de trabalho de nível educacional diferenciado. Entre 1901 e 1920, entraram no país nada menos que 1,5 milhões de estrangeiros, dos quais aproximadamente $60 \%$ se fixaram nas áreas urbanas e rurais de São Paulo.

Melhores condições sanitárias, de um lado, significavam, uma garantia para o sucesso da política governamental de atração de força de trabalho estrangeira e, de outro, impunham-se como uma necessidade de preservação do contingente ativo de trabalhadores, em um contexto de relativa escassez de oferta de trabalho. 0 destaque em matéria de atenção à saúde ficava, assim, por conta do controle de enfermidades, tais como a febre 
amarela, a peste bubônica, a varíola e outras, para as quais o governo federal impôs medidas de higiene, vacinação, notificação de casos, isolamento de enfermos e eliminação de vetores.

\section{Mortalidade de migrantes no município de São Paulo há 100 anos}

No final do século XIX e nas primeiras décadas do século XX, o estado de São Paulo recebeu importante corrente de imigrantes italianos e, em bem menor escala, de outras nacionalidades. A partir de 1908, iniciou-se outra grande corrente imigratória, a dos japoneses. Os imigrantes italianos vieram principalmente para trabalhar na agricultura (café), substituindo os escravos negros que haviam sido libertados em 1888. Após alguns anos de trabalho nas plantações de café, os italianos, na grande maioria, mudaramse para as cidades. 0 município de São Paulo recebeu muitos desses imigrantes e, no registro de óbito, como ainda atualmente, constava a nacionalidade do falecido. Na Tabela 1, estão apresentados os óbitos segundo a nacionalidade. Verifica-se que $74,6 \%$ eram brasileiros (nascidos na capital ou no estado de São Paulo ou em outros estados); 25,2\% eram estrangeiros e $0,2 \%$ tinham nacionalidade ignorada. Entre os estrangeiros predominavam os italianos (62,1\%). É interessante observar que ocorreram 16 óbitos de "africanos" e 1 "oriental", não tendo sido especificado o país. Quanto aos africanos, pode-se especular que poderiam ser ex-escravos não nascidos no Brasil, mas trazidos da África.

Tabela 1 - Mortalidade segundo nacionalidade e sexo. Município de São Paulo - 1902

\begin{tabular}{lrrrr}
\hline & Masculino & Feminino & Toral & \multicolumn{1}{c}{$\%$} \\
\hline Brasileiros & 2.009 & 1.873 & 3.882 & 74,6 \\
Italianos & 539 & 273 & 812 & 15,6 \\
Espanhóis & 64 & 40 & 104 & 2,0 \\
Portugueses & 168 & 75 & 243 & 4,6 \\
Alemães & 24 & 15 & 39 & 0,7 \\
Outros & 77 & 42 & 119 & 1,8 \\
TotaL & 2.881 & 2.318 & 5.199 & 100,0 \\
\hline
\end{tabular}


Para o conjunto dos óbitos, a taxa de natalidade verificada em 1902 foi de 33,3 nascimentos por mil habitantes; a taxa de natimortalidade foi de 55,4 por mil nascimentos. A mortalidade geral foi de 18,2 por mil habitantes, e a mortalidade infantil, 182,1 por mil nascidos-vivos.

Em 1901, Emílio Ribas adotou em Sorocaba, São Paulo, uma iniciativa pioneira de combate ao Aedes aegypti, que havia sido identificado no final do século anterior como o vetor da febre amarela. 0 exemplo de Ribas foi seguido por Oswaldo Cruz, que desencadeou a histórica campanha contra a febre amarela no Rio de Janeiro, entre 1903 e 1908. Em 1904, entra em vigor a lei de vacinação compulsória contra a varíola.

No nível central da federação, foi regulamentada em 1901 a Diretoria Geral de Saúde Pública. De um modo geral, a assistência à saúde, prestada por este e pelos órgãos federais que lhe sucederam, estava restrita às situações de epidemia e aos casos de especial interesse para o controle das condições de saúde pública, no eixo central da economia, havendo de fato quase nenhuma capacidade de atuação do poder federal na assistência individual à saúde. Com efeito, a assistência médico-hospitalar, nesse período, dependia em maior parte de entidades beneficentes e filantrópicas, como também das diversas mutualidades a que se filiavam os grupos de imigrantes de diversas nacionalidades, mas principalmente os portugueses, os espanhóis e os italianos.

Carlos Chagas, a partir de 1921, à frente da Diretoria Geral de Saúde Pública, promoveu expansão dos serviços de saúde para além do Rio de Janeiro. Em muitas situações, a autoridade sanitária se exercia de forma impositiva; por exemplo, no caso da lepra, poderia ser utilizada a força policial para obrigar pessoas suspeitas a realizar o exame diagnóstico ou para 0 isolamento compulsório dos doentes. Também era proibida a viagem de portadores da doença sem autorização prévia da autoridade sanitária do local de destino.

É na transição de uma economia agrário-exportadora para uma economia urbano-industrial, na década de 1930, que surgiu um sistema de assistência à saúde e, de modo geral, um sistema típico de proteção social no 
Brasil. Com a consolidação da atuação do Estado na regulação das atividades econômicas, essa mudança teve caráter predominantemente produtivista, com proteção diferenciada aos trabalhadores assalariados dos setores modernos da economia e se traduziu, em especial, na promulgação da legislação trabalhista e previdenciária.

A partir de 1930, com a depressão econômica mundial e a crise nos setores associados à exportação do café, o governo brasileiro começou a dar maior prioridade e incentivo à indústria. A produção industrial brasileira, que crescera à taxa média anual de 2,8, em 1920-29, passou a crescer à taxa de 11,2\%, em 1933-39 (ver Tabela 2).

Tabela 2 - Taxas médias percentuais de crescimento da economia. Brasil - 1920-39

\begin{tabular}{lccc}
\hline Setores & $1920-29$ & $1929-33$ & $1933-39$ \\
\hline Produção agrícola total & 4,0 & 2,5 & 1,6 \\
Produção agrícola exportada & 7,5 & 3,7 & 1,1 \\
Produção industrial & 2,8 & 4,4 & 11,2 \\
\hline
\end{tabular}

Fonte: Villela \& Suzigan, 2001.

As políticas sociais no período anterior à Revolução de 1930 eram fragmentadas e emergencialistas, embora existam algumas iniciativas de políticas sociais importantes na década de 1920, como a instituição por lei dos Departamentos Nacionais do Trabalho e da Saúde, a promulgação, em 1923, do Código Sanitário e da Lei Eloy Chaves sobre assuntos previdenciários. Os conflitos entre capital e trabalho eram regulados por legislação esparsa, sendo tratados basicamente pelo aparato policial. Questões de saúde pública eram tratadas pelas autoridades locais, não havendo por parte do governo central um programa de ação no sentido de atendê-las. A atuação do Estado restringia-se, em grande parte, a situações emergenciais, como as epidemias em centros urbanos.

$\mathrm{Na}$ década de 1940, ampliou-se bastante o mercado de trabalho urbano. Entre 1940 e 1950, o setor urbano aumentou em 1,5 milhão a oferta de empregos, enquanto o rural crescia apenas em 0,5 milhão. A inten- 
sificação da urbanização que se processava fez o país transitar de uma sociedade rural para uma industrial, embora ainda concentrada nos espaços do Rio de Janeiro e São Paulo. A participação da população urbana no total, que era de $31 \%$ em 1940, subiu para $36 \%$, em 1950 . Nesse esforço de urbanização, o papel do capital nacional foi de fundamental importância, assim como o do Estado, com seu enorme esforço na criação de infra-estrutura, especialmente de um novo sistema de transportes (rodoviário), de cunho eminentemente nacional e integrador.

No plano social, esse período caracterizou-se por mudanças importantes introduzidas pelo governo autoritário de Getúlio Vargas, tais como a consolidação da legislação trabalhista e a estatização da previdência social. Esta passou a ser organizada por meio dos Institutos de Aposentadorias e Pensões (IAPs), segundo grupos de categorias profissionais, com contribuições obrigatórias por parte de empregadores e empregados. Também houve alterações nas políticas de saúde e educação, caracterizadas pelo elevado grau de centralização de recursos e instrumentos institucionais/administrativos no governo federal, através do Ministério dos Negócios de Educação e Saúde Pública.

Diversas reformas no aparelho de Estado contribuíram para consolidar um Estado de Bem-Estar brasileiro baseado em políticas predominantemente voltadas para trabalhadores urbanos. Foi criado o Ministério do Trabalho e promulgada nova legislação trabalhista, formando as novas bases de uma política de regulamentação do trabalho e de uma organização política dos trabalhadores. Com especial atenção aos trabalhadores comerciários e industriários, foram regulamentados o trabalho feminino, o trabalho de menores e a própria jornada de trabalho. Questões de direitos, tais como férias, demissões e acidentes de trabalho, foram incluídas na nova legislação. Foi consagrada a intervenção do Estado nos conflitos trabalhistas com a criação da justiça do trabalho e a regulamentação explícita das formas de negociação salarial e organização sindical. 
No período compreendido entre 1945 e 1964, o Brasil viveu uma fase de democracia, mas muitas das estruturas corporativistas, construídas nos anos precedentes, permaneceram intactas, especialmente no campo das relações de trabalho. Do ponto de vista dos marcos institucionais, esse período é caracterizado pela criação de instrumentos legais voltados para o funcionamento de um governo democrático. Verifica-se a consolidação da indústria, com a implantação da indústria pesada e a expansão extraordinária da malha rodoviária, integrando mercados regionais, até então excluídos do processo comercial.

Com os novos segmentos, a estrutura industrial se alterou significativamente. Os bens de consumo não duráveis, que, em 1919, perfaziam $76 \%$ da produção industrial, caíram para $53 \%$, em 1959 , enquanto os bens intermediários passaram de $22 \%$ para $34 \%$. Ampliou-se a criação de empregos urbanos, que já representavam $45 \%$ do total da população, em 1960.

Com a instauração do governo militar, em 1964, foram realizadas as principais reformas econômicas e institucionais, com uma perspectiva centralizadora. Alterou-se a legislação trabalhista, sendo criadas instituições para promover uma política habitacional. Nessa fase, a integração de regiões a um mercado de nível nacional desencadeou o processo intenso de migrações rurais com destino urbano, com consequiências negativas nas condições de vida das populações residentes nas cidades, em decorrência do desemprego e do baixo nível salarial.

Do ponto de vista demográfico, a população brasileira vinha crescendo, desde início da década de 1950, a taxas de 3\% ao ano, em decorrência da queda da taxa bruta de mortalidade e mantendo-se a fecundidade em patamares ainda elevados. Agregue-se, ainda, 0 aceleramento das correntes migratórias rurais-urbanas, que atinge o ápice na década de 1960, contribuindo, fortemente, para uma urbanização descontrolada e concentradora, em período de tempo relativamente muito curto. 
Os ajustes realizados na economia entre 1965 e 1970 produziram uma grande concentração de renda. Inicia-se, então, um processo de discussão em torno do assunto, com as questões sociais voltando a ser motivo de preocupação, mesmo por parte dos principais gestores das políticas econômicas e sociais. Esta foi uma década de reflexão crítica diante dos aos problemas mencionados. Houve uma ampla discussão política nacional, envolvendo os baixos salários dos trabalhadores, o forte êxodo rural e a não reforma agrária, o agravamento dos problemas urbanos e suas carências sociais não atendidas, o problema das desigualdades regionais e os mecanismos para enfrentá-los etc.

Do ponto de vista da dinâmica demográfica, o período pós-1974 é também considerado aquele em que ocorreram as mais profundas rupturas com a dinâmica anterior, principalmente na área da reprodução feminina. Começaram a declinar, de forma acentuada, os níveis de fecundidade da mulher brasileira, primeiramente nas regiões mais desenvolvidas do CentroSul, depois, na década de 1980, também nas áreas mais atrasadas social e economicamente, como o Nordeste. Esta queda ocorreu de forma generalizada no território brasileiro, independentemente da situação social específica da mulher. Entretanto, o declínio da fecundidade passou a ter impactos positivos sobre as condições de sobrevivência das crianças, não só pela elevada diminuição do número de filhos por casal, mas também pelo aumento do intervalo entre nascimentos.

No governo militar, o modelo de crescimento adotado pressupunha a necessidade de se acumular renda para garantir as bases do crescimento, redistribuindo-a posteriormente. A concentração de renda, no entanto, tem custos sociais pesados. Para compensá-los e garantir a estabilidade política necessária ao crescimento econômico, o governo implementou uma série de políticas sociais de natureza assistencialista. Nesse período, são implementadas políticas de massa de cobertura relativamente ampla, através da organização de sistemas nacionais públicos, ou regulados pelo Estado, de provisão de serviços sociais básicos. 
0 modelo de Estado de Bem-Estar perdeu, ao longo dos governos militares, o caráter populista que vinha do período getulista e assumiu duas linhas definidas. A primeira, de caráter compensatório, constituída de políticas assistencialistas que buscavam minorar os impactos das desigualdades crescentes provocadas pela aceleração do desenvolvimento capitalista. A segunda, de caráter produtivista, formulava políticas sociais visando a contribuir com o processo de crescimento econômico. Foram elaboradas, por exemplo, as políticas de educação, com 0 objetivo de atender às demandas por trabalhadores qualificados e aumentar a produtividade da mão-de-obra semiqualificada.

Foi criado, em 1974, o Conselho de Desenvolvimento Social (CDS), diretamente ligado à Presidência da República, com o objetivo principal de assessoramento na formulação da política social e na coordenação das atividades dos ministérios. Isto permitiu a implantação de políticas de massa, de cobertura sem precedentes na América Latina, com reflexos altamente positivos nas condições gerais de vida daqueles segmentos sociais até então os mais afetados pelo modelo econômico excludente. Entre essas iniciativas, destacam-se: o Fundo de Apoio ao Desenvolvimento Social (FAS), que se propunha a financiar os programas e projetos na área social (1974); a reformulação dos mecanismos financeiros do Sistema Financeiro de Habitação (1974), pelo qual o Banco Nacional de Habitação deveria priorizar o atendimento habitacional a populações de baixa renda; a nova sistemática do Plano Nacional de Saneamento (1975), visando a ampliar o atendimento aos municípios mais carentes; o Programa Nacional de Alimentação e Nutrição (1976), concentrado nas linhas de suplementação alimentar a gestantes, nutrizes e crianças de 0 a 6 anos e escolares, para estimular o pequeno agricultor e 0 combate às carências nutricionais; e o Programa de Interiorização das Ações de Saúde e Saneamento no Nordeste - Puss - (1976), que tinha como objetivo dotar as comunidades do interior nordestino de estrutura básica de saúde pública.

Esse elenco de programas, de um modo geral, contribuiu favoravelmente para a melhoria geral dos indicadores de educação, saneamento bási- 
co, difusão da rede básica de saúde e cobertura vacinal. Entretanto, no início dos anos 1980, tais programas centralizados já apresentavam indícios de esgotamento e crise em seus aspectos organizacionais, sociais e sobretudo financeiros, levando a tentativas de mudanças dirigidas à sua racionalização.

Até as reformas ocorridas na década de 1980, o Estado de BemEstar brasileiro era caracterizado por centralização política e financeira em nível federal, fragmentação institucional, tecnocratismo, auto-financiamento, privatização e uso clientelístico das políticas sociais. Estas são características de um sistema de proteção social que não tem pretensões de funcionar como verdadeiro mecanismo redistributivo do produto da economia.

A partir de 1985 até 1988, com a Nova República, foram introduzidas importantes modificações nas políticas econômicas e sociais brasileiras: do ponto de vista econômico, um compromisso com o crescimento; do ponto de vista do social, os movimentos organizados da sociedade começam a ter maior presença nos conselhos de gestão nacional, nas áreas de saúde, previdência, educação e trabalho. 0 que se observa nesse período são discussões amplas destinadas à realização de reformas dos sistemas tributários, financeiro e administrativo, e de reformas na área social (educação, previdência social, habitação, assistência social, alimentação e nutrição). No caso da saúde, esse processo se dá através do movimento de Reforma Sanitária, que levou à criação do Sistema Único de Saúde (SUS).

No plano estratégico, a intervenção social do governo materializouse, por um lado, por meio de programas emergenciais voltados para 0 combate à fome, ao desemprego e à miséria. Ativaram-se os programas de alimentação já existentes, e novos foram criados (programa do leite para crianças carentes, programa de medicamentos e imunológicos) e foram implementadas medidas nas áreas de abastecimento, saúde, educação, assentamentos agrários, integração da pequena produção de alimentos e ampliação da proteção social para as camadas mais pobres da população. Fica 
evidenciada, nesta fase, a prioridade do social sobre o econômico, retirando a política social de sua posição tradicionalmente subordinada à política econômica. Isto terá repercussões bastante positivas nas condições gerais de saúde da população, em especial a infantil.

As mudanças promovidas no período entre 1985 e 1988 estão caracterizadas pela crítica à centralização institucional e financeira do sistema. Os diversos planos de ação governamental instituídos nesse período priorizam o resgate da 'dívida social', rejeitando a sujeição das políticas sociais às medidas de ajuste macroeconômico.

Os principais impulsos reformistas do Executivo federal, sobretudo no biênio 1985-1986, foram o reforço dos programas emergenciais no campo da suplementação alimentar, a incorporação da reforma agrária e do seguro-desemprego na agenda governamental e a instituição de grupos de trabalho e comissões setoriais. No Legislativo, a principal medida foi a conclusão de parte do processo constituinte com a promulgação da nova Constituição em outubro de 1988.

Entretanto, esses impulsos foram seguidos, no período 1990-1992, por um esvaziamento da estratégia reformista, mediante uma 'contra-reforma', caracterizada peḷ ampliação do assistencialismo e do clientelismo, e pelo desmonte da capacidade orçamentária e administrativa de intervenção do Estado no campo social. A descentralização passou a ocorrer de maneira acelerada e caótica, provocando vazios institucionais em determinados setores de política social e superposições em outros. Além da superposição institucional e de programas, as políticas sociais, nesse período, foram caracterizadas por cortes drásticos de orçamento, sob a justificativa de necessidade de descentralização administrativa.

A partir de 1993, a descentralização das políticas, a articulação de fato entre os diversos programas e a parceria entre governo e movimentos sociais foram inovações que permitiram uma redução das práticas clientelistas, o distanciamento das políticas assistenciais e a continuidade 
dos programas. A introdução de critérios de delimitação territorial do público-alvo, aliados aos de renda, permitiram uma melhor focalização dos beneficiários.

A nova fase das políticas sociais brasileiras seria marcada pela focalização com base em critérios mais amplos do que o da renda individual, o reforço da seletividade e da focalização sem perda do universalismo (com distribuição de benefícios na proporção inversa das carências), a redução do estatismo (com preservação do caráter público e gratuito dos serviços através de parcerias com movimentos sociais e o setor privado) e a maior aceitação e apoio, no meio político, a programas de transferência monetária direta, como os de renda mínima.

\section{Natalidade e fecundidade}

Entre fins do século XIX e meados do século XX, o Brasil apresentou um padrão demográfico relativamente estável, com pequenas oscilações dos níveis de fecundidade e de mortalidade. Estes níveis se mantiveram em patamares regularmente elevados, embora pequenos declínios da fecundidade possam ser observados. 0 comportamento reprodutivo da família brasileira durante todo esse período se caracterizava por uma concepção de família numerosa, típica de sociedades agrárias e precariamente urbanizadas e industrializadas. As grandes transformações desse padrão demográfico começam a ocorrer a partir da década de 1940, quando há consistente declínio dos níveis gerais de mortalidade, não acompanhado por um processo concomitante na natalidade.

A série de censos demográficos, que cobre um período de 128 anos a partir de 1872 , mostra que a população brasileira cresceu aproximadamente dez vezes ao longo do século $\mathrm{XX}$, embora o ritmo do crescimento venha diminuindo progressivamente nas últimas décadas (Tabela 3). 
Tabela 3 - População nas datas dos recenseamentos gerais e taxas médias de crescimento anual. Brasil - 1872-2000

\begin{tabular}{lrcr}
\hline $\begin{array}{l}\text { Datas dos recensea- } \\
\text { mentos gerais }\end{array}$ & População residente & $\begin{array}{c}\text { Taxa média geom. de } \\
\text { crescim. anual (\%) }\end{array}$ de crescimento (\%) \\
\hline $1 / 08 / 1872$ & $90930478^{*}$ & $>2,01$ & $>-1,49$ \\
$31 / 12 / 1890$ & $14333915^{*}$ & $>1,98$ & $>46,97$ \\
$12 / 31 / 1900$ & $17438434^{*}$ & $>2,91$ & $>-48,80$ \\
$9 / 1 / 1920$ & $30635605^{*}$ & $>1,49$ & $>60,40$ \\
$9 / 1 / 1940$ & 41165289 & $>2,39$ & $>25,10$ \\
$7 / 1 / 1950$ & 51941767 & $>2,99$ & $>-3,34$ \\
$9 / 1 / 1960$ & 70070457 & $>2,89$ & $>-14,19$ \\
$9 / 1 / 1970$ & 93139037 & $>2,48$ & $>-22,18$ \\
$9 / 1 / 1980$ & 119002706 & $>1,93$ & $>-15,54$ \\
$9 / 1 / 1991$ & 146825475 & $>1,63$ & \\
$8 / 1 / 2000$ & 169590163 & & \\
\hline
\end{tabular}

* População presente.

Fonte: IBGE. Censos demográficos de 1872 a 2000.

A maior taxa de crescimento ocorreu durante a década de 1950 , na média de 3,0\% ao ano, o que corresponde a um acréscimo relativo de 34,9\% no efetivo populacional. Naquela década, enquanto se acentuava o processo de declínio da mortalidade, a fecundidade manteve-se em patamares extremamente elevados.

0 processo de desaceleração do crescimento teve início na década de 1970, em função de uma queda inicialmente tímida da fecundidade, o que fez com que a taxa de crescimento fosse inferior a $2,5 \%$ ao ano. $\mathrm{Na}$ década de 1980, em consonância com a transição para níveis de fecundidade mais baixos, a taxa de crescimento declinou para $1,9 \%$ ao ano. No período mais recente, de 1991-2000, a taxa média geométrica de crescimento anual 
foi de apenas 1,63\%. 0 declínio dessa taxa é generalizado em todo o país, exprimindo-se na queda relativa do número de nascimentos e, em diversos casos, na sua redução absoluta.

Outro aspecto importante da evolução da população brasileira está relacionado ao processo de urbanização. Até 1960 , a maioria da população residia na área rural, à exceção da região Sudeste, que nessa data já apresentava $57 \%$ de sua população residente na área urbana. Como é sabido, o fenômeno da urbanização no Brasil está associado a fluxos migratórios internos, que se intensificaram a partir do início dos anos 1960 , tendo como principal área de atração a região Sudeste, concentradora das principais atividades econômicas no país. Em 1970, a taxa de urbanização dessa região chegou a $73 \%$, enquanto nas demais foi inferior a $50 \%$.

As regiões Sul e Centro-Oeste também começaram a se urbanizar de forma intensa a partir de meados da década de 1970. De início, o crescimento urbano coexistiu com uma atividade agrícola proporcionalmente muito forte, mas o processo mais recente de modernização favoreceu a expulsão populacional do campo, inclusive em áreas que, até os anos 1960 e 1970, representavam espaços de expansão da fronteira agrícola. Nas regiões Norte e Nordeste, onde os níveis de urbanização ainda são relativamente baixos, quando comparados aos das regiões Sudeste $(90,5 \%)$, Centro-Oeste $(86,7 \%)$ e Sul ( $81 \%)$, o incremento vem sendo gradual, chegando a 2000 com taxas de urbanização similares (69\%).

Tabela 4 - Taxas de urbanização. Brasil e Grandes Regiões - 1940-2000

\begin{tabular}{llllllll}
\hline Brasil e Grandes Regiões & 1940 & 1950 & 1960 & 1970 & 1980 & 1991 & 2000 \\
\hline Brasil & 31,42 & 36,16 & 44,67 & 55,92 & 67,59 & 75,59 & 81,23 \\
Norte & 27,75 & 31,49 & 37,38 & 45,13 & 51,65 & 59,05 & 69,83 \\
Nordeste & 23,42 & 26,40 & 33,89 & 41,81 & 50,46 & 60,65 & 69,04 \\
Sudeste & 39,42 & 47,55 & 57,00 & 72,68 & 82,81 & 88,02 & 90,52 \\
Sul & 27,73 & 29,50 & 37,10 & 44,27 & 62,41 & 74,12 & 80,94 \\
Centro-Oeste & 21,52 & 24,38 & 34,22 & 48,04 & 67,79 & 81,28 & 86,73 \\
\hline
\end{tabular}

Fonte: IBGE. Censos Demográficos de 1940 a 2000. 
Em síntese, pode-se afirmar que o Brasil sofreu profundas alterações durante as últimas quatro décadas, ao passar da situação de um país essencialmente rural para outra, em que mais de $80 \%$ de sua população (137 milhões) reside em áreas urbanas. Mudaram as realidades e situações vivenciadas pelas populações. De um lado, aumentaram as demandas por serviços públicos (educação, saneamento básico, serviços de saúde etc.), insuficientes para atender ao contingente populacional que acorre constantemente às grandes cidades. De outro lado, alterou-se a dinâmica demográfica, sobretudo no tocante ao comportamento reprodutivo, impondo a redefinição de políticas públicas nas áreas da saúde, educação, mercado de trabalho e previdência social.

O declínio da mortalidade acentuou-se e ganhou consistência a partir de 1940 , inicialmente na população adulta e, mais tarde, nos segmentos infantil e infanto-juvenil (Gráfico 1). Quanto à natalidade, seu declínio consolidou-se somente na década de 1960, acompanhando grandes transformações sociais e econômicas que ocorriam, principalmente nas regiões do Centro-Sul, as quais recebiam grandes contingentes populacionais de outras áreas e se urbanizavam rapidamente.

Gráfico 1 - Evolução da natalidade e da mortalidade. Brasil - 1881-2000

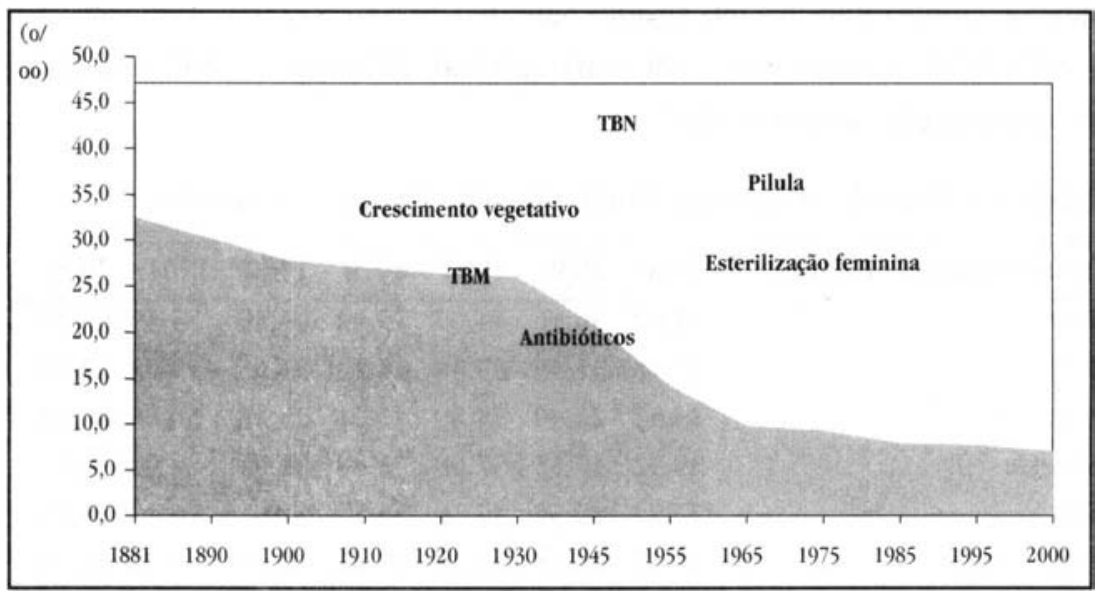

Fonte: IBGE. Censos Demográficos. 
0 auge do crescimento demográfico brasileiro, alcançado na década de 1950 ( $3 \%$ ao ano), correspondeu ao período em que foi mais elevada a diferença entre a natalidade e a mortalidade. Estimativas derivadas dos censos demográficos de 1991 e de 2000 indicam, respectivamente, que a taxa bruta de natalidade reduziu-se de 26,7 por mil habitantes, na década de 1980, para 22,0 por mil, no ano 2000 . Em paralelo, os níveis brutos de mortalidade decaíram mais lentamente nas últimas décadas, visto que já se apresentavam em patamares relativamente baixos, oscilando apenas em função de comportamentos específicos por idade (redução da mortalidade infantil e infanto-juvenil, e novo perfil epidemiológico marcado, por exemplo, pelo aumento da mortalidade por causas externas).

Em suma, a componente natalidade e os padrões correlatos de fecundidade são os principais agentes de mudanças no padrão demográfico brasileiro. 0 seu movimento de declínio é que explica a razão pela qual a taxa de crescimento demográfico registrado no Brasil é, atualmente, inferior a $1,7 \%$ ao ano.

\section{Expectativa de vida}

Durante os primeiros trinta anos do século $\mathrm{XX}$, a população brasileira teve um aumento na sua sobrevivência de aproximadamente três anos, correspondente a incremento de apenas $8 \%$, que reflete a elevada incidência de mortalidade no período. Santos (1978), utilizando o modelo de populações estáveis, estimou a esperança de vida ao nascer da população brasileira para os anos de 1900, 1910, 1920 e 1930, respectivamente, em 33,7 anos, 34,08 anos, 34,51 anos e 36,49 anos.

Para as décadas seguintes, os valores desse indicador estão apresentados, por regiões, na Tabela 5, mostrando significativa melhoria nos níveis de sobrevivência da população brasileira. Em 1930-40, a vida média passou a ser de 41,5 anos, o que corresponde a um ganho de cinco anos, superior ao observado durante os trinta anos anteriores. As diferenças 
regionais já se refletiam nos níveis de sobrevivência das populações residentes nas regiões brasileiras. 0 Nordeste apresentava, em 1940, os menores valores de esperança de vida ao nascer ( 36,7 anos), contra 49,2 anos no Sul, 47,9 no Centro-Oeste e 43,5 no Sudeste. De certa forma, essas diferenças refletiam a prioridade de investimentos econômicos orientados para essas últimas regiões, que também se beneficiaram de iniciativas nos sistemas de saúde pública, previdência social, infra-estrutura urbana e regulamentação do trabalho, a partir de 1930. Todos esses fatores concorreram para o controle e redução das doenças infecto-contagiosas, até então de elevada incidência e letalidade, contribuindo para a elevação da vida média ao nascer.

Tabela 5 - Esperança de vida ao nascer. Brasil e Grandes Regiões - 1930-2000

\begin{tabular}{l|ccccccc}
\hline Brasil e Grandes & \multicolumn{7}{|c}{ Esperança de vida ao nascer } \\
\cline { 2 - 8 } Regiões & $1930 / 40$ & $1940 / 50$ & $1950 / 60$ & $1960 / 70$ & 1980 & 1990 & 2000 \\
\hline Brasil & 41,5 & 45,5 & 51,6 & 53,5 & 61,8 & 65,5 & 68,6 \\
Norte & 40,7 & 44,6 & 53,4 & 54,6 & 61,3 & 67,4 & 68,5 \\
Nordeste & 36,7 & 38,9 & 41,0 & 45,5 & 56,9 & 62,2 & 65,8 \\
Sudeste & 43,5 & 49,0 & 57,2 & 57,3 & 64,5 & 66,5 & 69,6 \\
Sul & 49,2 & 52,8 & 60,3 & 60,0 & 63,5 & 68,7 & 71,0 \\
Centro-Oeste & 47,9 & 51,1 & 56,7 & 58,9 & 63,5 & 67,8 & 69,4 \\
\hline
\end{tabular}

Fonte: IBGE.Censos Demográficos.

Em meados da década de 1950 , a esperança de vida ao nascer era de 51,6 anos, o que representou um aumento, em duas décadas, de cerca de dez anos em média nacional (contra 41,5 anos em 1930/40). Na região Nordeste, contudo, o incremento foi de apenas quatro anos, enquanto na Sudeste os ganhos alcançaram quatorze anos.

Entre 1955 e 1965 e, mais precisamente, até meados da década de 1970, a tendência de aumento da expectativa de vida teve continuidade, porém de forma mais lenta. Nas regiões Sudeste e Sul, os valores mantiveram-se praticamente inalterados, em torno de 57 anos e 60 anos, respectivamente. Tal constatação está relacionada às circunstâncias de um período de 
crise estrutural da economia, em que as condições de saúde dos grupos mais vulneráveis da população, sobretudo crianças, ficaram dependentes de políticas públicas compensatórias. Como se verá mais adiante, essas circunstâncias tiveram impacto sobre a mortalidade infantil, e as regiões Sudeste e Sul foram as mais afetadas, exatamente por serem o núcleo hegemônico da economia nacional e, portanto, mais expostas aos efeitos das crises.

A partir de meados da década de 1970, a tendência de queda da mortalidade retomou o seu curso, coincidente com a expansão da rede assistencial e escolar e com a ampliação acelerada da infra-estrutura de saneamento básico, sobretudo da rede de abastecimento de água. Observase, no país, redução significativa nos padrões históricos da desigualdade regional diante da morte, tendo a região Nordeste apresentado, durante 0 período de 1975 a 2000, os maiores ganhos da esperança de vida. Esse fato está associado à redução da mortalidade infantil, que teve a contribuição de programas nacionais de atenção à saúde materno-infantil dirigidos ao atendimento pré-natal, ao parto e ao puerpério, à vacinação, ao aleitamento materno e à reidratação oral, principalmente a partir de 1980 .

Os diferenciais da sobrevivência por sexo também passaram a ter maior significado a partir de então, provavelmente associados à ascensão da mortalidade por causas violentas, que afetou, de forma especial, os adultos jovens do sexo masculino. Em 1980, a diferença situava-se em 6,8 anos na média nacional, tendo aumentado, em 2000, para 7,8 anos. Na região Sudeste, a vida média os homens é cerca de 9 anos inferior à das mulheres, seguida pelas regiões Sul $(7,8$ anos) e Centro-0este (6,7 anos).

\section{Mortalidade infantil}

Estima-se que, por volta de 1930, a taxa de mortalidade infantil para a média da população brasileira atingia valores acima de 160 óbitos por 1000 nascidos-vivos. A partir desse ano, configuram-se, de forma incontes- 
tável, trajetórias distintas para as regiões brasileiras (Gráfico 2). Enquanto as regiões Centro-Oeste, Sudeste e Norte mostravam, já antes de 1940, tendências lentas de declínio da mortalidade, a região Sul e, principalmente a Nordeste, apresentavam níveis estáveis. Observe-se que a região Sul, diferentemente da Nordeste, já vinha exibindo taxas significativamente menores, por razões históricas relacionadas à colonização, que recebeu a influência de importantes fluxos de migrantes europeus. Na região Nordeste, a mortalidade infantil começou a declinar somente ao final da década de 1940, mesmo assim mais lentamente do que nas demais regiões.

Gráfico 2 - Evolução da mortalidade infantil. Grandes Regiões - 1930-2000

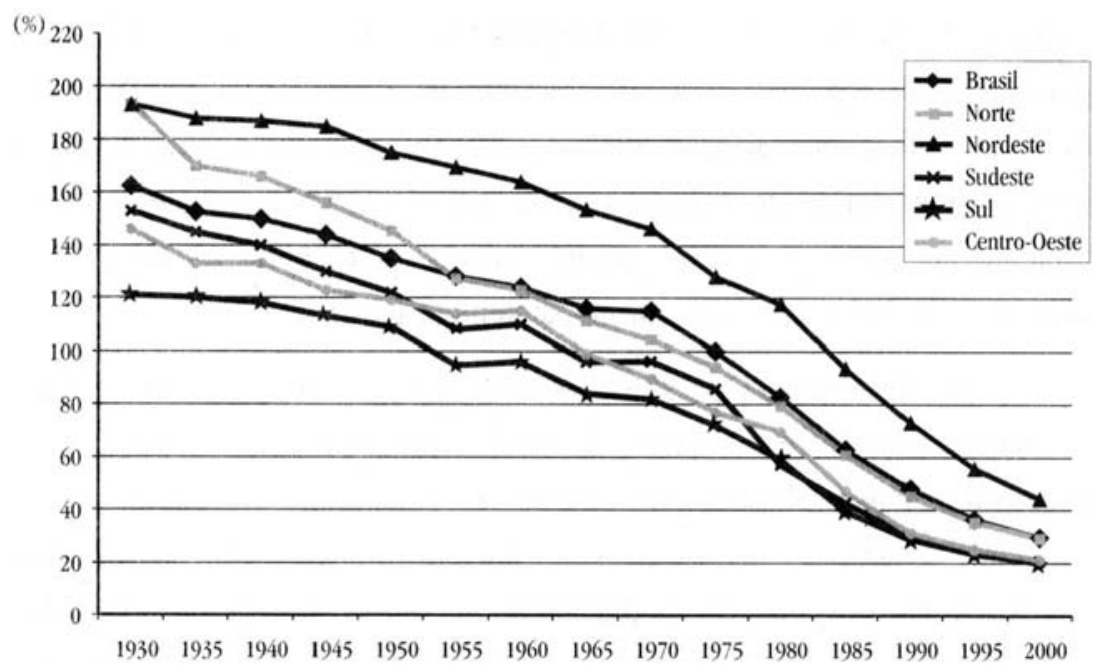

Fonte: IBGE. Censos Demográficos de 1940-2000.

No período 1955-70, o ritmo de redução da mortalidade é desacelerado, chegando-se inclusive a observar aumento das taxas nas regiões Sudeste e Sul. Essas regiões, conforme indicado anteriormente, sofreram mais intensamente os efeitos econômicos e institucionais da crise estrutural que ocorreu no período, entre eles: 1) substancial redução do poder de 
compra, tendo o valor do salário mínimo diminuído cerca de $45 \%$ entre 1959 e 1974; 2) deterioração de certos serviços básicos, a exemplo do saneamento; 3) enorme fluxo, para o Sudeste, de migrantes originários de áreas de alta mortalidade, principalmente o Nordeste.

Superado esse período crítico, e com o Estado já se reorganizando sob novas feições, a mortalidade infantil retomou o seu declínio em todas as regiões. A melhoria geral dos indicadores de mortalidade, após 1975, parece não estar fortemente associada ao nível de renda, mas sim a intervenções na área de saúde pública. Nessa fase, foram implementadas importantes medidas governamentais, destinadas a fortalecer a infra-estrutura de saneamento, saúde, habitação e assistência materno-infantil, na perspectiva da integração regional. Tal política certamente contribuiu para a redução acentuada da mortalidade infantil, que se observa no último qüinqüênio da década de 1970 e durante toda a década seguinte.

Na região Nordeste, a velocidade de queda da mortalidade infantil durante a década de 1980 foi inferior à das demais regiões. Essa situação modifica-se na década de 1990, quando a taxa de mortalidade infantil para a região Nordeste sofreu uma redução de quase $40 \%$ (de 72,9 óbitos por mil nascidos-vivos, em 1990, para 44,2, em 2000), contra $35 \%$ no Norte e 31 $32 \%$ nas demais regiões. Esse fato confirma o efeito de intervenções sobre fatores ambientais, capazes de produzir maior impacto na mortalidade de crianças no período pós-neonatal, entre um e onze meses de vida completos.

O Brasil chegou ao final do século $\mathrm{XX}$ apresentando, na média nacional, taxa de mortalidade infantil em torno de $30 \%$. Esse número, ainda elevado, reflete a persistência de grandes disparidades inter-regionais, que impõem a adoção de estratégias de intervenção diferenciadas. Enquanto nas regiões Norte e Nordeste predominam causas de mortalidade redutíveis por ações básicas de saúde e de saneamento, nas regiões Sudeste, Sul e CentroOeste, onde a mortalidade infantil já se encontra em patamar bem abaixo (cerca de 20\%), o ritmo de declínio tenderá a ser mais lento, por ser depen- 
dente, cada vez mais, de investimentos na melhoria das condições qualitativas de assistência pré-natal, ao parto e ao recém-nascido.

\section{Estrutura etária da população}

Até o final da década de 1970 , a população brasileira apresentava características que a identificavam como predominantemente jovem, o que decorria do longo período em que os níveis de fecundidade foram muito elevados. Uma das mais fortes evidências encontradas na comparação temporal refere-se ao estreitamento progressivo da base da pirâmide populacional, com reduções significativas do número de crianças e jovens, no total da população (Gráfico 3).

Gráfico 3 - Estrutura relativa por sexo e idade. Brasil - 1930-2000

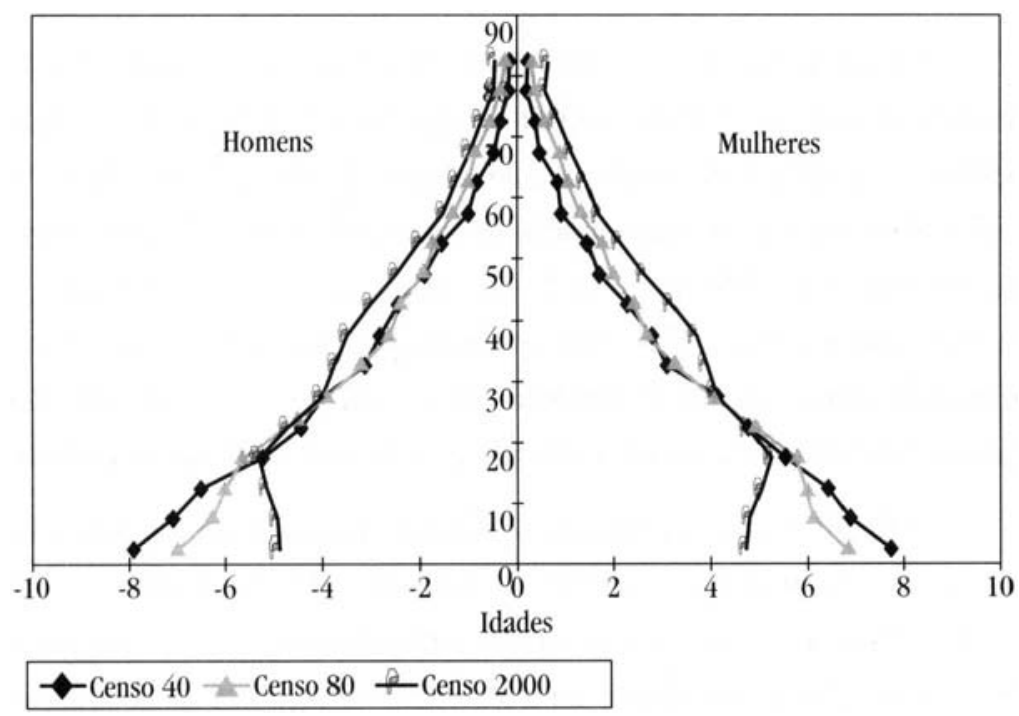

As estruturas das pirâmides revelam os efeitos de nascimentos de coortes originárias de períodos de fecundidade ainda elevada, percebendose nitidamente, a partir de 1980, o crescimento da população em idade ativa, 
representada pelos jovens e adultos jovens. Também se observa 0 aumento, principalmente relativo, do grupo etário idoso, o que resulta da diminuição do número de nascimentos, como também da elevação tendencial da esperança de vida.

O impacto das mudanças no padrão demográfico sobre as estruturas etárias é complexo e extremamente relevante para a identificação das características das distintas gerações e coortes populacionais no país. As alterações ocorridas, de forma gradativa, nos diversos grupos etários, deslocam-se temporalmente e, assim, afetam a estrutura do conjunto. Nas últimas décadas, a transição demográfica brasileira vem determinando novas questões e demandas à sociedade, principalmente em relação aos distintos serviços que devem ser prestados aos grupos específicos de crianças, jovens e idosos.

\section{Determinantes básicos das condições de saúde}

\section{Saneamento}

Os primeiros sistemas e serviços de abastecimento de água e esgotos no Brasil foram criados através de concessões à iniciativa privada, feitas em geral pelos governos estaduais. No período que se estendeu de meados do século XIX ao início do século XX, o Estado brasileiro, ainda incipiente, concedeu, a empresas privadas nas principais cidades, o direito de criar e explorar os principais serviços públicos, entre eles os de saneamento. Em geral, essas empresas eram estrangeiras e, em sua maioria, inglesas. No entanto, a experiência não obteve resultados satisfatórios, sobretudo pela dificuldade de retorno, via tarifas, dos investimentos necessários à expansão das redes, ficando, por isso, restritas aos núcleos centrais inicialmente implantados. Esta precariedade na oferta dos serviços gerou protestos e alimentou revoltas populares. 
Em decorrência da insatisfação com a qualidade dos serviços prestados pela iniciativa privada, diversos governos estaduais passaram a romper os contratos, encampando os serviços. Este processo deu-se majoritariamente de 1893 até a segunda metade do século XX. Dessa forma, foram constituídos, nos governos estaduais, órgãos de administração direta, na forma de repartições ou inspetorias. Com a Constituição de 1891, ficaram mais definidos os papéis das diferentes esferas de poder, aumentando a capacidade executiva dos governos. Assim, também as prefeituras passaram a criar serviços de água e esgotos.

Este período, de criação de órgãos da administração direta, se estende até os anos 1940. Os investimentos para expansão eram feitos, em maior parte, com recursos orçamentários, sobretudo estaduais, e o custeio era parcialmente feito com as tarifas. Um aspecto importante deste período é a construção de um saber nacional de engenharia sanitária, até então muito dependente de tecnologia inglesa. Nesse sentido, há que ser destacada a fundamental contribuição de Saturnino de Brito, engenheiro que, atuando na implantação de obras de saneamento nas principais cidades brasileiras, desde a última década do século XIX até 1929 , tem sido reconhecido como o pai da engenharia sanitária brasileira.

A partir de críticas à burocracia, à dependência de recursos orçamentários e ao caixa único, característico da administração direta, foram constituídas as primeiras autarquias de saneamento, objetivando maior autonomia desses serviços. Assim, surge uma diretriz para o setor saneamento, que é a auto-sustentação tarifária e o financiamento com recursos onerosos para a implantação de sistemas de água no Brasil. Em 1952, foram instituídos os serviços autônomos de água e esgotos, os SAAES, originalmente proposto pelo Serviço Especial de Saúde Pública (SESP, órgão criado em 1942). Algumas repartições ou inspetorias passaram a ser chamadas de departamento, na forma de autarquias. Em 1953, foi criado o primeiro plano de financiamento federal para abastecimento de água, que teve no SESP órgão técnico assessor. Foram também criados outros órgãos federais que de- 
senvolviam ações de saneamento, como o Departamento Nacional de Obras e Saneamento (DNOS) e o Departamento Nacional de Obras Contra a Seca (DNOCS), e, ainda, na área da saúde, o Departamento Nacional de Endemias Rurais (DNERu). Os órgãos do setor saúde - Sesp e DNERu (atuavam no controle de endemias e deram contribuições importantes, na implantação tanto de novos sistemas de abastecimento de água e de esgotos, quanto de serviços e desenvolvimento de tecnologias.

$\mathrm{Na}$ década de 1960, por indução da Sudene, no Nordeste, e do Banco Interamericano de Desenvolvimento (BID), em outras regiões do país, foram criadas empresas públicas de economia mista, em sua maioria, no âmbito estadual, com $o$ intuito de prover maior racionalidade administrativa e autonomia aos serviços de água e esgotos. 0 Banco Nacional de Habitação (BNH), criado em 1964, teve, a partir de 1965, sua atuação ampliada para 0 financiamento de ações de saneamento, intensificada sobretudo a partir de 1968, com a instituição do Sistema Financeiro do Saneamento (SFS). Esta foi a primeira linha regular de financiamento para sistemas de abastecimento de água e esgotos no Brasil, abrangendo órgãos públicos estaduais e municipais.

Com a adoção de parâmetros racionais, se buscava a eficiência com a alocação de recursos retornáveis, via tarifas, viabilizando a expansão da oferta e superando as restrições de recursos orçamentários. Esta era uma demanda dos técnicos do setor que havia surgido já na I Conferência Nacional de Saúde de 1941. Entre 1960 e 1970, houve uma expansão de 11\% na cobertura da população urbana por abastecimento de água, atingindo (apenas) pouco mais da metade desta população. Deu-se um aumento significativo de serviços autárquicos e empresariais, reduzindo a participação da administração direta na gestão do saneamento no Brasil, que ficou circunscrita, basicamente, a municípios de pequeno porte.

Em 1971, é instituído o Plano Nacional de Saneamento (Planasa), que se constituiu em um divisor de águas na história do saneamento brasileiro devido à sua magnitude e à reestruturação que acarretou no setor. 
O Planasa, como muitos afirmam, não surgiu do nada, foi um tributário de valores que vinham se consolidando no setor, como a racionalidade na gestão, a autonomia dos serviços, a alocação de recursos retornáveis, a não-dependência de recursos orçamentários, a auto-sustentação tarifária etc. Dois suportes foram centrais para a viabilidade deste plano: a existência de um fundo público com recursos fartos, o Fundo de Garantia por Tempo de Serviço (FGTS), e a centralização do financiamento e gestão nas companhias estaduais. Como o BNH apenas financiava empresas estaduais e os recursos orçamentários para saneamento foram fechados, os municípios se viram obrigados a conceder os serviços às companhias estaduais, ficando também alijados como poder concedente, não participando em nenhuma etapa do processo decisório.

A implantação do Planasa, considerando os aspectos citados, aliados a uma política arrojada de formação de recursos humanos, que teve importante participação da Opas, possibilitou uma expansão significativa da cobertura de abastecimento de água e, em menor escala, do esgotamento sanitário nas décadas de 1970-80. A cobertura de abastecimento de água da população urbana passou de pouco mais da metade, em 1970, para cerca de $90 \%$, em 1990. Em 1986, o BNH foi extinto, e as suas funções foram incorporadas pela Caixa Econômica Federal (CEF).

Nos anos de 1990, diante da conjuntura político-econômica mundial, retornaram - após quase um século - as propostas privatizantes para o saneamento brasileiro. A partir de 1994, cerca de quarenta cidades privatizaram seus serviços de água ou esgotos. Emergia uma dupla polarização no setor: a gestão estadual versus a municipal, e a pública versus a privada. Esta tônica permeou a década de 1990 e continua no século XXI. Com o processo de ampliação da democracia e da descentralização das políticas públicas a partir da Constituição de 1988, os municípios passaram a demandar poder decisório na gestão do setor, havendo uma forte reação por parte das empresas estaduais. Entretanto, para viabilizar o processo de privatização, seria necessário modificar o marco legal, assunto que ainda continua em debate. 
Conforme pode ser verificado na Tabela 6 , a evolução da cobertura de abastecimento de água e esgotamento sanitário para a população urbana no Brasil cresceu significativamente deste a década de 1960 , quando os investimentos com recursos retornáveis começaram a ter maior volume e regularidade. Considerando-se a população urbana, nas últimas quatro décadas, a que teve maior incremento na cobertura no abastecimento de água foi a de 1970, ao passo que a de 1990 teve o pior desempenho. Com relação ao esgotamento sanitário, os anos 1980 apresentaram melhor desempenho para 0 mesmo período. Levando em conta 0 grande crescimento da população urbana nesse período, considera-se de significativa importância a ampliação da oferta desses serviços. Entre os anos de 1970 e 1991, o abastecimento de água teve um incremento de $62 \%$, e o de esgotamento sanitário de $100 \%$. Na década de 1990 , no que se refere ao abastecimento de água, este crescimento foi mínimo, de 1,9\%. Com relação ao esgotamento sanitário, o crescimento foi maior, mas não se pode identificar com precisão o número.

Tabela 6 - Cobertura dos domicilios particulares permanentes, segundo serviços de saneamento, por tipo e ano. Brasil - 1969-2000

\begin{tabular}{l|cccccccccc}
\hline Tipo de serviço & 1960 & 1970 & & 1980 & \multicolumn{2}{c}{1991} & \multicolumn{2}{c}{2000} \\
\hline \multirow{3}{*}{ Abastecim. de água } & $\%$ & $\%$ & Incremento & $\%$ & Incremento & $\%$ & Incremento & $\%$ & Incremento \\
\cline { 2 - 10 } & 43,4 & 54,4 & 11,0 & 76,4 & 22,0 & 87,9 & 11,5 & 89,8 & 1,9 \\
Esgotamento sanitário & 27,7 & 22,3 & $-5,4$ & 36,0 & 13,7 & 44,6 & 14,9 & 56,01 & 11,4 \\
\hline
\end{tabular}

Obs: 0 Censo 2000 inclui, nas informações sobre esgotamento sanitário, não apenas domicílios ligados à rede geral, mas também domicilios ligados à rede pluvial, diferentemente do Censo 1991.

Fonte: IBGE.

Outros dados do Censo de 2000 também merecem destaque. Em relação às condições de moradia, 1,8 milhões dos domicílios urbanos atendidos por rede geral de água não têm canalização interna. No tocante às instalações sanitárias, há 3,7 milhões de domicílios que não dispõem de sanitários e 7,5 milhões que não dispõem de banheiro.

Há, portanto, neste início de século XXI, um grande passivo social relativo ao não-acesso, ou a um deficiente acesso, a serviços básicos como o 
abastecimento de água e esgotos, que aliado a condições precárias de moradia, continua produzindo efeitos perversos no que diz respeito à morbimortalidade por Doenças Relacionadas ao Saneamento Ambiental Inadequado (DRSAI).

No início da década de 1980 , a taxa de mortalidade por DRSAI era de 30 óbitos por 100.000 habitantes. Nos primeiros anos da década seguinte, a taxa era de 11 óbitos por 100.000 habitantes e, nos últimos anos, a taxa era de 9 óbitos por 100.000 habitantes. Em 1999, ocorreram mais de 13 mil óbitos decorrentes das DRSAI e, em 2000, mais de meio milhão de internações hospitalares foram causadas por essas doenças.

Uma importante iniciativa destinada a ampliar a infra-estrutura de saneamento no país foi o Projeto Alvorada, iniciado em 2001, pelo qual o governo federal pretendia investir recursos significativos em obras de abastecimento de água, melhorias sanitárias domiciliares e esgotamento sanitário. Os investimentos estavam dirigidos aos municípios que apresentam Índice de Desenvolvimento Humano (IDH) menor ou igual a 0,500, taxa de mortalidade infantil acima de 40,0 por mil e freqüência importante de doenças entéricas de veiculação hídrica. De acordo com esses critérios, seriam beneficiados 1.847 municípios de 21 estados, predominantemente da região Nordeste.

Diante da fragilidade legal-institucional e do passivo socioambiental que caracterizam o estágio atual, algumas urgências se configuram no setor saneamento brasileiro neste início de século XXI. Em primeiro lugar, o estabelecimento de um marco legal claro, que defina nitidamente a titularidade dos serviços de abastecimento de água e esgotos e das competências dos três níveis de poder.

Em segundo lugar, a formulação de uma política nacional de saneamento ambiental, na qual princípios e diretrizes já consagrados no SUS, como universalidade, eqüidade, integralidade, descentralização e controle e participação social, sejam priorizados por meio de instrumentos políticos, 
técnico-operacionais claros. Em uma política nacional de saneamento, a intersetorialidade se constitui condição essencial para a integralidade das ações, envolvendo os setores de saúde, meio ambiente, desenvolvimento urbano e habitação. A definição de papéis de cada um desses setores, de acordo com a sua natureza, é fundamental para superar a fragmentação e a superposição que caracterizam as políticas públicas nacionais. 0 setor saúde tem papel nuclear no desenvolvimento de políticas urbanas, pela maturidade com que vem implementando a descentralização, o controle social e a territorialização de suas ações.

A permanência de um grande passivo na área de saneamento ambiental no Brasil está a exigir medidas ousadas e urgentes visando à universalização da oferta de sistemas à população, com qualidade de acesso e sem descuidar da recuperação, manutenção e operação desses sistemas.

\section{Saúde ambiental}

Embora diversos aspectos da dinâmica e das relações entre 0 meio ambiente e a saúde humana tenham sido incorporados ao arcabouço legal do setor, ainda está por ser definido um projeto estratégico para a área de saúde ambiental no Brasil, que expresse ações do governo e da sociedade, dando conta da complexidade de fatores sociais e econômicos envolvidos na causalidade das condições de risco para a saúde da população.

A partir da década de 1970, o desenvolvimento da saúde ambiental no país pode ser analisado em três períodos distintos. 0 primeiro segue-se à conferência sobre meio ambiente, realizada em Estocolmo em 1972, que marca a preocupação mundial com as questões ambientais e sua relação com a saúde humana. Nesse período, as iniciativas brasileiras se expressaram no fortalecimento da capacidade institucional de órgãos ambientais e em iniciativas do campo da saúde e do meio ambiente, destacando-se a 
criação do Centro de Saúde do Trabalhador e Ecologia Humana, na Fundação Oswaldo Cruz, e de organizações governamentais de meio ambiente, no nível estadual.

Entre os eixos estruturantes que concorreram para 0 início de uma preocupação com a saúde ambiental no Brasil, destacam-se o desenvolvimento da Secretaria Nacional de Meio Ambiente (Sеma) e a criação do Sistema Nacional de Meio Ambiente (SIsvama). No setor saúde, foi criada a Divisão Nacional de Ecologia Humana e Saúde Ambiental, no Ministério da Saúde, e também coordenações estaduais de saúde ambiental. Foram realizadas também as primeiras conferências nacionais de saúde do trabalhador e de saúde ambiental, cujas teses são em parte asseguradas na Constituição de 1988.

A instituição de mecanismos de controle e proteção ambiental esteve associada ao desenvolvimento de grandes pólos industriais, especialmente o petroquímico, na década de 1970 . A preocupação com riscos potenciais de exposição humana a esses produtos gerou a criação de centros de intoxicação e de laboratórios de toxicologia humana. Se, de um lado, a expansão da fronteira agrícola e o investimento na monocultura extensiva trouxeram consigo a disseminação do uso de agrotóxicos; de outro, a resposta ao controle e ao tratamento de seus efeitos adversos à saúde humana desencadeou o processo de registro de agrotóxicos e de outros mecanismos de vigilância sanitária e epidemiológica.

Desse modo, as estruturas de saúde ambiental se organizavam em torno de problemas, tais como saneamento ambiental, exposição humana a agrotóxicos, mercúrio, chumbo, fatores de risco relacionados à qualidade da água para consumo humano e saúde do trabalhador. Os grupos de pressão da sociedade, especialmente as organizações não-governamentais (ONGs) e personalidades ambientalistas relacionadas à proteção da biodiversidade e à agenda verde, também exerceram importante papel no debate e na reivindicação de mecanismos de resposta a questões de saúde relacionadas à degradação ambiental. 
Um outro aspecto também considerado estruturante à época foi o desenvolvimento de mecanismos de cooperação internacional nas áreas de toxicologia, epidemiologia ambiental, metodologias de avaliação de risco à saúde pública e competência laboratorial, tendo como referência a ação e as estratégias da Opas, em particular do Centro Pan-Americano de Ecologia Humana e Saúde (ECO), visando especialmente à formação de recursos humanos, à elaboração de guias e manuais, ao desenvolvimento de bases de dados e de sistemas de informação e, não menos importante, ao apoio político para as iniciativas de desenvolvimento da saúde ambiental no Brasil.

0 período descrito pode ser identificado como o período de tomada de consciência, culminando com significativa participação do setor saúde brasileiro na cúpula Rio-92.

0 segundo período, iniciado com a Conferência do Rio em 1992 e que se estende até o final da década de 1990, pode ser identificado com o desmonte do processo anterior. A implantação do projeto político de consolidação do modelo neoliberal buscou reduzir o papel do Estado e da sociedade civil organizada na definição e condução das políticas públicas estratégicas do país. 0 SUS então instituído voltou-se, no período inicial de implantação, principalmente para a adequação e universalização do modelo de assistência médica individual, com pouca ênfase na saúde coletiva e, ainda em menor grau, na relação entre saúde e ambiente.

0 terceiro período, entre o final da década de 1990 e o momento atual, pode ser identificado com a retomada do desenvolvimento da área de saúde ambiental, expressando iniciativas de construção de uma política de saúde ambiental, no âmbito do Ministério da Saúde. Foram marcos desse período: 1) a estruturação da Agência Nacional de Vigilância Sanitária; 2) a reformulação da Fundação Nacional de Saúde; 3) a definição de eixos agregadores na Fundação 0swaldo Cruz; 4) a intensificação da cooperação técnica com a OPAs, viabilizando parcerias com outros países americanos. Mais recentemente, constituiu-se, no Ministério da Saúde, a Co- 
missão Permanente de Saúde Ambiental, e celebrou-se termo de cooperação entre os ministérios da Saúde e do Meio Ambiente para construir a agenda federal de saúde ambiental. 0 Ministério da Saúde também passou a ter maior atuação nos grandes fóruns nacionais, como o Conselho Nacional de Meio Ambiente, o Conselho Nacional de Recursos Hídricos e o Conselho Nacional de Defesa Civil.

Esse fenômeno de retomada mais recente representa, para o setor saúde, o desafio de desenvolver um projeto que o habilite a atuar sobre os múltiplos fatores ambientais capazes de influenciar a saúde da população. Isso envolve a consolidação das bases teóricas, filosóficas e conceituais das políticas públicas, a adequação de competências institucionais, o fortalecimento de parcerias e compromissos nas três esferas de governo, a participação do setor privado, a produção de conhecimentos e de tecnologias apropriadas.

\section{Nutrição}

A prevalência da desnutrição em crianças de até cinco anos de idade tem sido medida no Brasil por um conjunto de indicadores antropométricos que relacionam altura com idade, peso com altura e peso com idade. Tais indicadores ajudam a acompanhar tendências importantes das condições de saúde da população, particularmente as que estão associadas à pobreza. Entre esses indicadores, destaca-se a avaliação do crescimento linear, que relaciona altura com idade e revela o efeito de agravos nutricionais crônicos, decorrentes de uma alimentação deficiente de longa duração e de episódios repetidos de doenças infecciosas que costumam ocorrer nesta condição.

Em 1996, a prevalência de retardo de crescimento situava-se em $10,4 \%$, no país como um todo. As taxas eram especialmente elevadas nas regiões Norte (16\%) e Nordeste (18\%), e existiam diferenças expressivas entre áreas urbanas (8\%) e rurais (19\%). No entanto, apesar de ainda elevadas, essas taxas aparecem como resultado de uma tendência declinante 
que se acentuou nos anos 1990 (Tabela 7). No período entre 1989 e 1996, o declínio da prevalência do retardo do crescimento alcançou uma média anual de 4,8\%, comparada com 3,7\% do período entre 1975-1989.

Tabela 7 - Evolução da prevalência (\%) de retardo de crescimento na população de menores de cinco anos de idade. Brasil - 1975, 1989 e 1996

\begin{tabular}{|c|c|c|c|c|}
\hline \multicolumn{3}{|c|}{ Prevalência anual } & \multicolumn{2}{|c|}{ Variação no período (\%) } \\
\hline 1975 & 1989 & 1996 & $1975-1989$ & $1989-1996$ \\
\hline 32,9 & 15,7 & 10,4 & $-3,7$ & $-4,8$ \\
\hline
\end{tabular}

Fonte: Monteiro, Benício \& Freitas. (1977).

$\mathrm{Na}$ análise desagregada por regiões geográficas e por áreas urbano/ rural, foi observado na região Nordeste um avanço inédito nesse indicador de desnutrição para o último período em estudo. A prevalência de desnutrição decresceu a uma média anual de 6,5\% nas áreas urbanas do Nordeste, superando, pela primeira vez, o declínio ocorrido na região Centro-Sul $(5,5 \%)$. No entanto, o declínio foi bem menos acentuado nas áreas rurais ( $2,6 \%$ no Nordeste contra $2,8 \%$ no Centro-Sul).

Essas análises abrangem apenas dois anos da efetivação do plano de estabilização da economia (Plano Real) e não permitem extrapolar tendências para o período mais recente, posterior a 1996. Para explicar essa tendência declinante da prevalência do retardo do crescimento infantil, três principais determinantes têm sido aventadas pelos pesquisadores: 1) a expansão do acesso a serviços de saúde, incluindo a maior cobertura por atividades de vacinação e acompanhamento do desenvolvimento das crianças e melhor assistência pré-natal e ao parto, no caso das mães; 2) a elevação do nível de escolaridade das mães; 3) a ampliação da rede pública de abastecimento de água. Portanto, as melhorias das condições nutricionais das crianças podem, em grande parte, ter sido alcançadas independentemente de incrementos na renda familiar total ou per capita. 
Alguns indicadores que comprovam ter havido uma melhoria incontestável das condições de assistência às crianças entre $1986 \mathrm{e}$ 1996, associada, provavelmente, ao estabelecimento do SUS, são mostrados na Tabela 8.

Tabela 8 - Evolução das crianças (\%) não cobertas por serviços de saúde. Brasil - 1986 e 1996

\begin{tabular}{l|rrc}
\hline Indicadores & 1986 & 1996 & Variação Anual (\%) \\
\hline Sem assistência pré-natal & 24,3 & 12,5 & $-4,8$ \\
Sem assistência ao parto & 17,8 & 6,7 & $-6,2$ \\
Não imunizadas & 45,0 & 18,8 & $-5,8$ \\
Sem qualquer assistência & 7,9 & 3,2 & $-5,9$ \\
\hline
\end{tabular}

Fonte: Monteiro, Benício \& Freitas. (1977).

Em relação à obesidade, constata-se que a prevalência do problema tem crescido em crianças e adultos de ambos os sexos, em todas as regiões e classes de renda. De 1975 a 1996, entre mulheres em idade fértil que possuíam crianças menores de cinco anos de idade, a proporção das que apresentavam índice de massa corporal superior a $30 \mathrm{~kg} / \mathrm{m} 2$ praticamente dobrou, passando de $5,3 \%$ para $10,1 \%$.

Entre as carências nutricionais específicas, a mais importante é a deficiência de ferro, distribuída em todas as regiões e atingindo, sobretudo, crianças e gestantes de menor renda familiar. Os índices de prevalência em pré-escolares têm variado de $48 \%$ a $51 \%$. Dados para 1996, sobre o consumo de alimentos em sete áreas metropolitanas, indicam baixa adequação de ferro à dieta (40-60\%).

Com vistas à redução da anemia ferropriva e à prevenção de patologias de desenvolvimento de tubo neural em bebês, o Ministério da Saúde está desenvolvendo um projeto para fortificação de farinhas de trigo e de milho com ferro e ácido fólico, financiado pela $\mathrm{CIDA} /$ Canadá, e que conta com a parceria da Opas e da EMBrapa. 
A deficiência de vitamina A tem sido demonstrada, desde a década de 1980 , em crianças na região Norte e em áreas de pobreza da região Sudeste. Com o objetivo de eliminar a hipovitaminose A e a xeroftalmia, foram tomadas iniciativas de distribuição em massa de megadoses de vitamina A para crianças menores de cinco anos, bem como para puérperas, por ocasião da alta na maternidade. Faltam, todavia, estudos de âmbito nacional ou regional que permitam avaliar o impacto dessas medidas.

A prevalência de bócio endêmico foi significativamente reduzida com a iniciativa de iodatar o sal de consumo, mas persistem áreas de deficiência de iodo nas regiões Norte e Centro-Oeste, bem como em alguns estados das regiões Sul, Sudeste e Nordeste. Um inquérito em escolares de seis a quatorze anos de idade revelou, em três estados, níveis médios baixos de excreção urinária de iodo. Em seis estados, os níveis de iodação do sal eram inferiores a 10mg/g. A OPAs tem apoiado o Ministério da Saúde nas ações de combate à deficiência de iodo e na realização de inquéritos para determinar a prevalência desta carência nutricional.

Em 1999, foi aprovada a Política Nacional de Alimentação e Nutrição, que visa a garantir a qualidade dos alimentos colocados para consumo e promover práticas alimentares saudáveis, bem como prevenir e controlar distúrbios nutricionais. Para suprir as necessidades calóricas de gestantes, nutrizes e crianças de até seis anos de idade, foi lançada em 2001 a "bolsa-alimentação", que consiste em apoio financeiro mensal a famílias pobres, condicionado ao compromisso de cumprir uma agenda positiva em saúde e nutrição, que inclui consultas de pré-natal e vacinação regular, acompanhada pelos serviços de saúde.

\section{Mudanças nos padrões de morbi-mortalidade}

As mudanças demográficas ocorridas durante o século XX estão relacionadas, por sua vez, a profundas modificações nos padrões epidemiológicos brasileiros, sobretudo na composição da mortalidade por 
grupos de causas. As doenças infecciosas e parasitárias (DIP), que representavam $45,7 \%$ do total de óbitos informados no país em 1930, passaram a constituir, no ano de 1999 , apenas $5,9 \%$ das mortes com causas definidas. Enquanto isso, as doenças cardiovasculares (DCV) seguiram uma tendência inversa, aumentando sua participação, de $11,8 \%$ para $31,3 \%$, no total dos óbitos ocorridos no mesmo período (Gráfico 4). Analisando a evolução recente das taxas padronizadas de mortalidade (por 100.000 habitantes) para os principais grupos de causas definidas, observa-se que as DCV correspondiam, em 1999, à taxa de 146,4, seguindo-se as causas externas $(70,2)$ e as neoplasias $(66,4)$. Cabe ressaltar, na série histórica dos dados de mortalidade disponíveis, certa discrepância verificada para o ano de 1991, quando teria havido uma redução importante das taxas, em todos os grupos de causas.

Gráfico 4 - Mortalidade proporcional segundo grupos de causas selecionadas. Brasil e capitais - 1930-1998

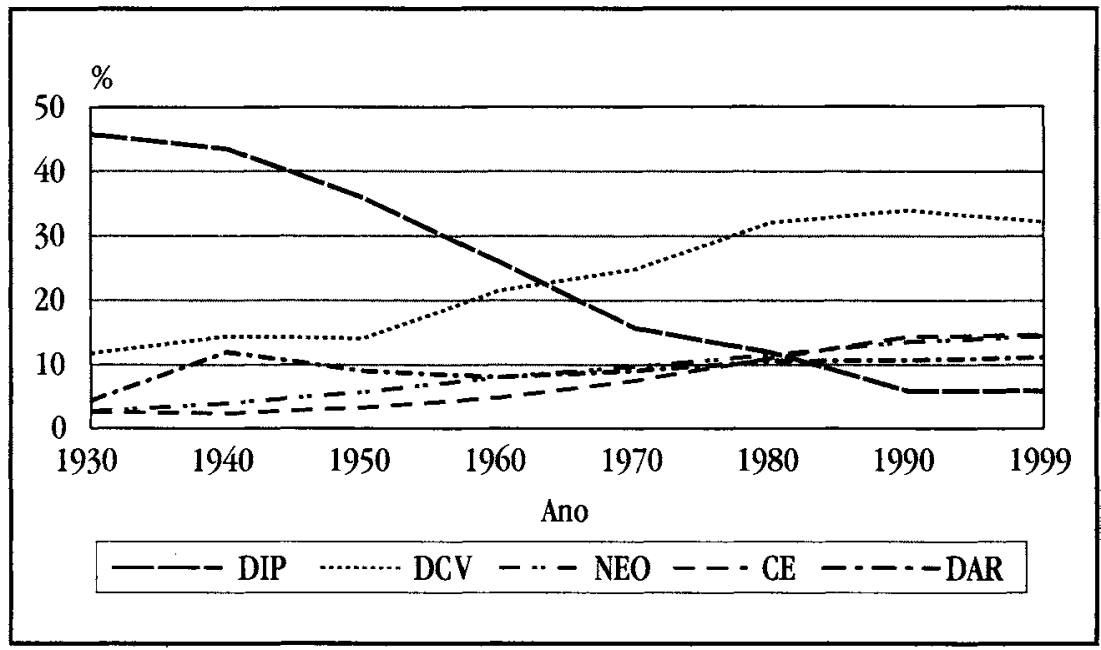

Obs: Excluídas as causas mal-definidas.

Fontes: FIocRuz/Radis, Dados, n. 7, 1984; MS. FNS. Datasus. 
A partir da segunda metade da década de 1980, observa-se tendência de declínio das taxas padronizadas de mortalidade para as DCV, enquanto as neoplasias e as causas externas interrompem sua tendência ascendente (Gráfico 5), em função da redução das taxas para algumas causas específicas. As doenças respiratórias, que em décadas anteriores não tinham participação expressiva na composição da mortalidade, têm permanecido estáveis na última década, figurando como a quarta causa de óbito na população total. A mortalidade por doenças infecciosas e parasitárias persiste com tendência descendente, iniciada em décadas anteriores, tendo apresentado taxa de 28,0 óbitos por 100.000 habitantes, em 1999. Na análise dos indicadores de mortalidade, deve-se ressalvar a elevada proporção de óbitos por causas mal definidas, como um dos fatores limitantes da qualidade dos dados disponíveis.

Gráfico 5 - Taxa de mortalidade padronizada por grupos de causas. Brasil 1981-1999

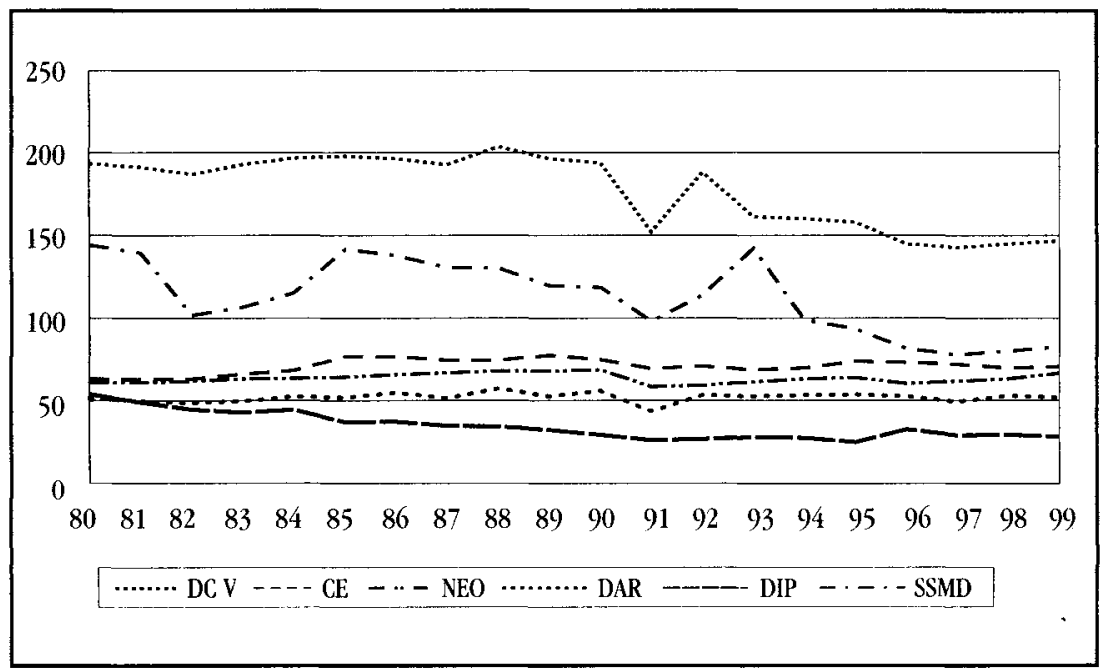

Fonte: MS. FunaSa. CENEPI. 
A situação epidemiológica pode ser analisada também pelos dados de morbidade hospitalar, que são amplamente disponíveis no Brasil e refletem, em parte, a ocorrência das formas clínicas mais severas das doenças. Quanto aos dados de morbidade de base não hospitalar, existe maior disponibilidade para as DIP, em especial para as doenças de notificação obrigatória. Como se verá a seguir, as tendências nos indicadores de morbidade apresentam semelhanças, mas também importantes diferenças, quando comparadas com as tendências observadas nos indicadores de mortalidade.

Utilizando-se a base de dados do sistema de informação hospitalar (SIH) do SUS, para o período de 1984 a 2001, foram analisadas as tendências da participação relativa das hospitalizações por grupos de doenças que tiveram destaque como causa de mortalidade, em relação ao total de hospitalizações no país. As doenças cardiovasculares, a primeira causa de mortalidade, representaram a segunda causa de internações. É interessante notar que as doenças cardiovasculares têm apresentado uma tendência lenta, porém constante, de redução da sua participação proporcional no total de internações (Gráfico 6), com um pequeno incremento nos últimos três anos. As neoplasias, com uma participação média anual de $3 \%$ do total das internações, apresentaram tendência estável no período.

Gráfico 6 - Proporção de internações por grupos de causas. Brasil - 1984-1999

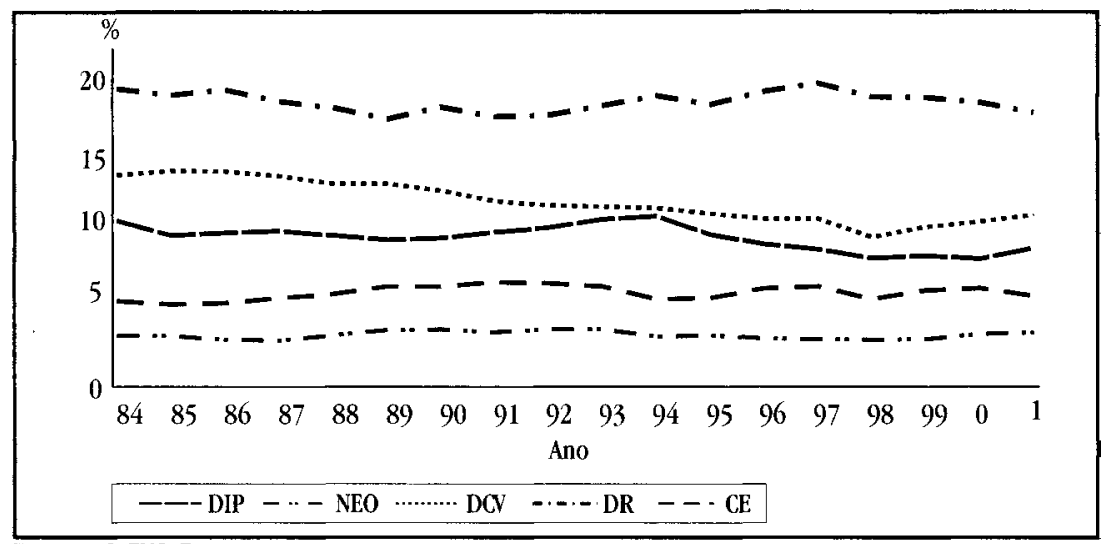

Fonte: MS. FNS. Datasus 
Quanto à proporção de internações por doenças infecciosas, em relação ao total de internações, não se observa uma tendência de redução na mesma intensidade que a verificada para a mortalidade. Nos últimos 15 anos, para o país como um todo, as doenças classificadas no capítulo das DIP têm apresentado valores próximos a $10 \%$ do total de internações, sendo mais elevados nas regiões Norte e Nordeste. Na composição das causas de internações por DIP, para 0 ano de 2001, destacam-se as doenças infecciosas intestinais, que representaram $59,6 \%$ do total de internações, no país, e $69,5 \%$, na região Nordeste.

Para as doenças respiratórias e as causas externas, as tendências observadas têm também pouca oscilação, em toda a série analisada. Enquanto as doenças respiratórias são responsáveis por aproximadamente $16 \%$ das internações - metade destas representadas pelas pneumonias - as causas externas contribuem com cerca de 5,5\% desse total. Vale ressaltar que, entre todos os grupos de causas de internação, incluindo os que não foram analisados na discussão sobre mortalidade, a maior proporção deve-se a motivos relacionados à gravidez, parto e puerpério (23,9\%, em 2001).

Alguns contrastes emergem na compatibilização das informações nas categorias de morbidade ou mortalidade, quanto à ordem de frequiência na participação dos diversos grupos de causas. Tal quadro justifica-se pelo fato de que a ocorrência do óbito é uma expressão bem definida da gravidade da doença, ao passo que a hospitalização não segue necessariamente esta ordem de determinação. Como exemplo, tem-se a grande proporção de internações pelo grupo de causas relacionadas à gravidez, parto e puerpério, que, com raras exceções, não configuram no seu conjunto nenhuma situação de gravidade. Porém, aqui deve-se chamar a atenção para a questão da mortalidade materna, a qual, apesar de sua aparentemente baixa magnitude, apresenta, no Brasil, taxas muito altas quando comparadas a outros países, refletindo deficiências na assistência pré e pós-natal. Entretanto, alguns agravos podem evoluir com quadros severos, porém, na medida em que tenham baixa letalidade ou sejam potencialmente reversíveis pela ação dos serviços 
de assistência à saúde, apresentam baixa mortalidade. Esse fenômeno acontece, por exemplo, com relação às doenças respiratórias, explicando as diferenças observadas, na ordem de freqüência, entre seus indicadores de morbidade e de mortalidade.

Apesar da redução significativa da participação das doenças transmissíveis no perfil da mortalidade, elas ainda têm impacto importante sobre a morbidade no país, como foi visto nos indicadores de morbidade hospitalar. Para algumas dessas doenças, ainda não há medidas eficazes de prevenção e controle. No entanto, a perda de importância relativa das doenças transmissíveis, principalmente no último quarto do século XX, criou, na opinião pública, uma falsa expectativa de que todo esse grupo de doenças estaria próximo à extinção. Esse quadro não é verdadeiro para o Brasil, e nem mesmo para os países desenvolvidos, como demonstrado pelos movimentos de emergência de novas doenças transmissíveis, como a Aids; de ressurgimento, em novas condições, de doenças 'antigas', como a cólera ou a dengue; de persistência de endemias importantes, como a tuberculose, e de ocorrência de surtos inusitados de doenças, como a febre do oeste do Nilo, nos Estados Unidos.

A situação atual das doenças transmissíveis no Brasil apresenta um quadro complexo, que compreende quatro categorias de tendências: de erradicação, de declínio, de persistência e de emergência ou reemergência. Os tópicos seguintes contêm um resumo da evolução histórica de algumas doenças que compõem cada um desses grupos, e das iniciativas governamentais que, ao longo do século XX, foram adotadas para combatê-las.

\section{Doenças transmissíveis erradicadas}

\section{Varíola}

Até a década de 1950, o Brasil, ao contrário de outros países das Américas, ainda não havia iniciado campanhas de vacinação em massa contra a varíola. 0 número de casos oficialmente registrados nesse período era 
bastante reduzido: variou entre 749 , em 1950, a 6.561, em 1960. Esses números, provenientes sobretudo da Fundação Sesp e da rede pública de centros de saúde e hospitais, nitidamente subestimava a incidência real dessa enfermidade, tendo em conta a dimensão populacional do país. Outro fator importante foi a predominância de uma forma clínica branda da doença - a varíola minor, mais conhecida por alastrim - que, décadas antes, havia substituído a forma major, mais grave e facilmente reconhecida. Por volta de 1960, o Brasil era praticamente o único país do continente americano em que a varíola ainda era endêmica.

Em 1958, o Brasil juntou-se a outros países-membros da Opas no esforço de erradicar a varíola nas Américas. Logo após o Instituto Oswaldo Cruz ter inaugurado sua linha de produção da vacina, foi lançada, em 1962, a primeira grande campanha contra a varíola no país, feita em forma descentralizada pelas secretarias de saúde dos estados. Devido à insuficiente motivação das autoridades locais e à falta de supervisão central, a campanha alcançou aplicar somente 24 milhões de doses, para uma população de $\mathbf{8 0}$ milhões de habitantes.

Atendendo a disposição da XVIII Assembléia Mundial de Saúde, o Ministério da Saúde instituiu, em 1966, a Campanha de Erradicação da Varíola (CEV), subordinada diretamente ao Ministro. A CEV recebeu substancial assistência técnica e logística da OPAs/OMS, com recursos do Programa Intensificado de Erradicação da Varíola, estabelecido em 1967. A estratégia de erradicação baseou-se na vacinação de pelo menos $90 \%$ da população brasileira e na implementação de ações intensivas de vigilância epidemiológica. A fase de vacinação em massa foi conduzida diretamente pelo Ministério da Saúde, em articulação com os governos estaduais, valendo-se do emprego da pistola de injeção automática, introduzida em 1965.

$\mathrm{Na}$ fase de vigilância epidemiológica, foi organizado em todo o país um sistema de notificação e investigação imediata de casos suspeitos de varíola, que permitiu rápido e efetivo controle da transmissão da doença. 
0 grande êxito dessa estratégia foi comprovado, de forma inequívoca, em trabalhos pioneiros realizados nos estados do Paraná, Bahia, Minas Gerais e Rio Grande do Sul, tendo servido de base para a instituição do Sistema Nacional de Vigilância Epidemiológica, em 1975.

No Gráfico 7, observa-se a incidência notificada de casos de varíola no período 1967-1971, em comparação com o número acumulado de doses de vacina aplicadas. 0 significativo aumento entre 1968 e 1969, de 4.372 para 7.407 casos, reflete o resultado de investigações de campo, que chegaram a detectar, para cada caso notificado, cerca de 40 a 50 outros, antes desconhecidos. Ao final de 1970, já se acreditava que a varíola havida sido eliminada do país. Em março de 1971, contudo, foi descoberto um novo surto localizado em favela da cidade do Rio de Janeiro, durante operação de rastreamento realizada de casa em casa. Do total de vinte casos então detectados, os dois últimos resultaram de transmissão intra-hospitalar, em abril de 1971. Foram estes os últimos casos de varíola conhecidos no continente americano.

Gráfico 7 - Casos de varíola notificados e número cumulativo de vacinações por períodos de quatro semanas. Brasil - 1967-1971

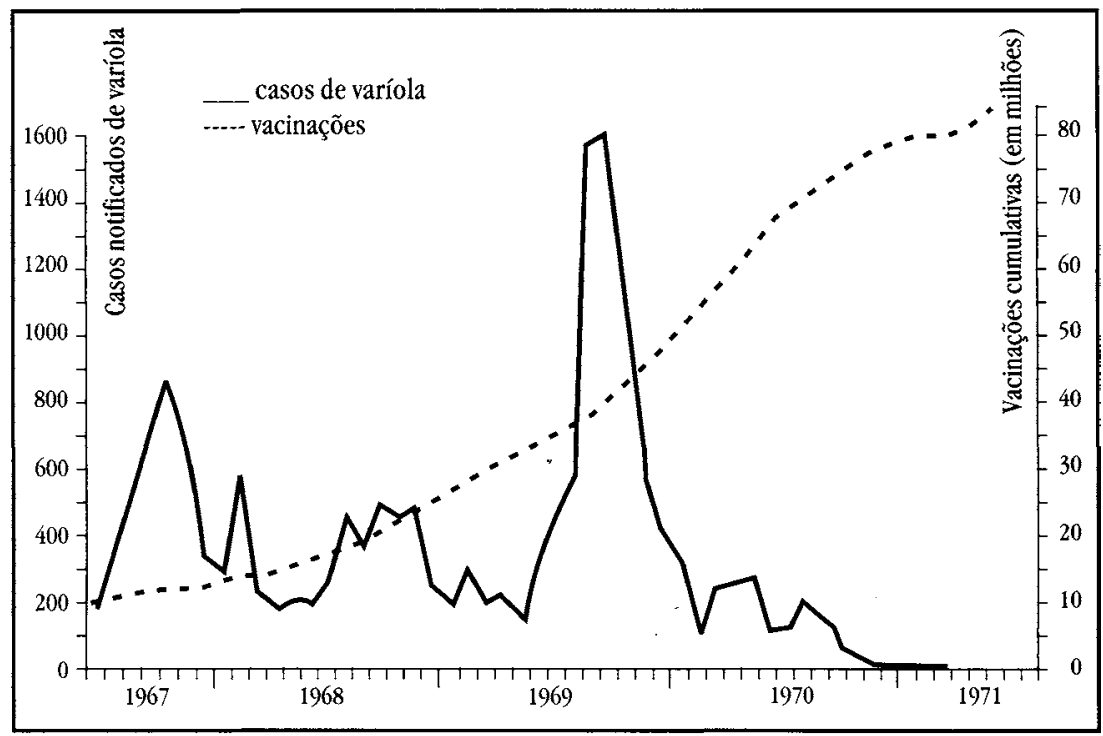


0 programa manteve-se em funcionamento durante os dois anos seguintes, para consolidar o sistema de vigilância epidemiológica implantado e intensificar a vacinação em áreas de menor cobertura. Em 1973, uma comissão internacional enviada pela Organização Mundial da Saúde (OMS), após examinar toda a documentação disponível e inspecionar atividades em campo, declarou a varíola erradicada no território brasileiro. Em janeiro de 1980, o Ministério da Saúde suspendeu a produção da vacina antivariólica e a sua aplicação em todo o país.

\section{Poliomielite}

Embora a ocorrência de casos esporádicos de poliomielite no Brasil seja referida às últimas décadas do século XIX, há evidências de que a doença se tornou mais freqüente a partir do início século $\mathrm{XX}$, conforme relatos no Rio de Janeiro (1909-1911) e em São Paulo (1918). A partir da década de 1930, foram observados surtos de certa magnitude em Porto Alegre (1935), Santos (1937), São Paulo e Rio de Janeiro (1939). Na década de 1940, várias capitais foram acometidas, como Belém (1943), Florianópolis (1943 e 1947), Recife (1946) e Porto Alegre (1945). A partir da década de 1950, tornou-se nítida a dispersão da doença para o interior do país. Em 1953, houve no Rio de Janeiro a maior epidemia registrada na cidade, que atingiu a taxa de 21,5 casos por 100 mil habitantes.

Essa evolução crescente da doença, mesmo que evidenciada a partir de relatos isolados e de informações incompletas, é similar à observada em outras partes do mundo. No decorrer da primeira metade do século XX, a melhoria das condições sanitárias restringiu a transmissão natural do vírus da poliomielite em certas camadas da população brasileira, condicionando a formação de maiores contingentes de suscetíveis à doença, em faixas etárias mais propensas à forma paralítica. Tal comportamento foi caracterizado em inquérito sorológico realizado em 1956, no Rio de Janeiro, que mostrou 
menor imunidade natural à poliomielite nos grupos populacionais de condição socioeconômica mais elevada, aos quais correspondiam 60 a $70 \%$ dos casos paralíticos conhecidos.

0 advento da imunização ativa contra a poliomielite, principalmente a oral de vírus vivos atenuados, no início da década de 1960, modificou o perfil epidemiológico da doença. Nas áreas onde a vacinação passou a ser sistematicamente realizada, como as trabalhadas pela Fundação Sesp, a poliomielite ficou restrita a casos esporádicos. De maneira geral, porém, os esforços foram esporádicos e insuficientes, faltando um programa de controle integrado e de abrangência nacional, que assegurasse o suprimento permanente de vacinas e coberturas elevadas em todo o país. A poliomielite passou a apresentar, então, um padrão de comportamento condicionado pela desigualdade de acesso a serviços de vacinação. Estando desprotegida grande parcela da população infantil, sobretudo nas classes sociais de menor renda, manteve-se a circulação contínua de poliovírus selvagens, sobretudo a do tipo 1 .

Em 1971, houve um importante esforço para debelar a doença, com a instituição, pelo Ministério da Saúde, do Plano Nacional de Controle da Poliomielite. 0 Plano baseava-se na realização de campanhas sistemáticas de vacinação no âmbito de cada estado, executadas em um só dia, mediante ampla mobilização da sociedade. 0 Ministério provia assistência técnica aos estados e supria os quantitativos de vacina necessários. Até 1973, o Plano foi implementado em 14 estados, mostrando-se operacionalmente viável, mas faltaram ações de vigilância epidemiológica que permitissem evidenciar 0 seu impacto.

Em 1974, as atividades do Plano foram absorvidas pelo Programa Nacional de Imunizações (PNI), cuja orientação passou a dar ênfase à vacinação de rotina na rede de serviços, e não mais à estratégia de campanha. Contudo, em função dos baixos resultados de cobertura alcançados, epidemias de poliomielite continuaram a ocorrer, até o final da década, em todos 
os estados brasileiros. Não obstante, a Fundação SEsP instituiu, nesse período, um sistema nacional de vigilância que passou a acumular informação epidemiológica consistente, com base em investigação clínica, epidemiológica e laboratorial dos casos notificados de paralisias flácidas agudas. Com 0 apoio da Fundação Oswaldo Cruz, outros centros de virologia no país passaram a identificar os tipos de poliovírus circulantes.

Finalmente, em 1980, foi estabelecido um processo decisivo de controle da doença, que consolidou a experiência adquirida nos serviços de saúde do país durante vários anos, em distintas iniciativas. Tal processo fundamentou-se na estratégia de "dias nacionais de vacinação contra a poliomielite" e teve êxito extraordinário, apesar de certo ceticismo internacional e das críticas que recebeu inicialmente de sanitaristas brasileiros. Não apenas produziu impacto imediato, como mostrou-se sustentável por mais de vinte anos consecutivos, passando a absorver, de forma seletiva, outras vacinas do PNI. No modelo adotado, as ações são planejadas e executadas descentralizadamente nos níveis estadual e municipal, porém segundo diretrizes nacionais. Por meio de ampla mobilização social e de instituições públicas, em todos os níveis, tem sido assegurado pleno acesso da população a uma rede de postos de vacinação organizada especialmente, em dias agendados duas vezes ao ano.

Os resultados alcançados no Brasil estimularam a iniciativa da OPAS, em 1985, de erradicar a poliomielite do continente americano. A partir de então, a instituição promoveu eficientes mecanismos de articulação das iniciativas nacionais, com base na adoção de critérios técnicos comuns, o que logrou interromper a transmissão da poliomielite no continente, declarada em 1994 por uma comissão científica internacional.

No Gráfico 8, apresenta-se a evolução do número de casos de poliomielite conhecidos no Brasil de 1968 a 1994, indicando-se as medidas de intervenção que conduziram à eliminação da doença. Em destaque, o pico epidêmico em 1975 (cerca de 3.600 casos) - quando se iniciam ações 
intensificadas de vigilância - e a redução drástica do número de casos, que seguiu à introdução dos dias nacionais de vacinação, em 1980. Outro momento marcante da evolução do processo, foi o surto ocorrido em meados da década de 1980 (612 casos em 1986), na região Nordeste, causado pelo poliovírus tipo 3 e que acometeu crianças com esquema básico de vacinação completo. Uma investigação conduzida com apoio da OPAS e do Centro de Controle de Doenças, dos Estados Unidos, demonstrou a necessidade de duplicar a concentração do componente tipo 3 da vacina, o que passou a ser recomendado para todo o continente. Os dois últimos casos de poliomielite no Brasil foram registrados em abril de 1989, no estado da Paraíba.

Gráfico 8 - Incidência de poliomielite e estratégias de controle pela vacinação. Brasil e região Nordeste - 1968-1994

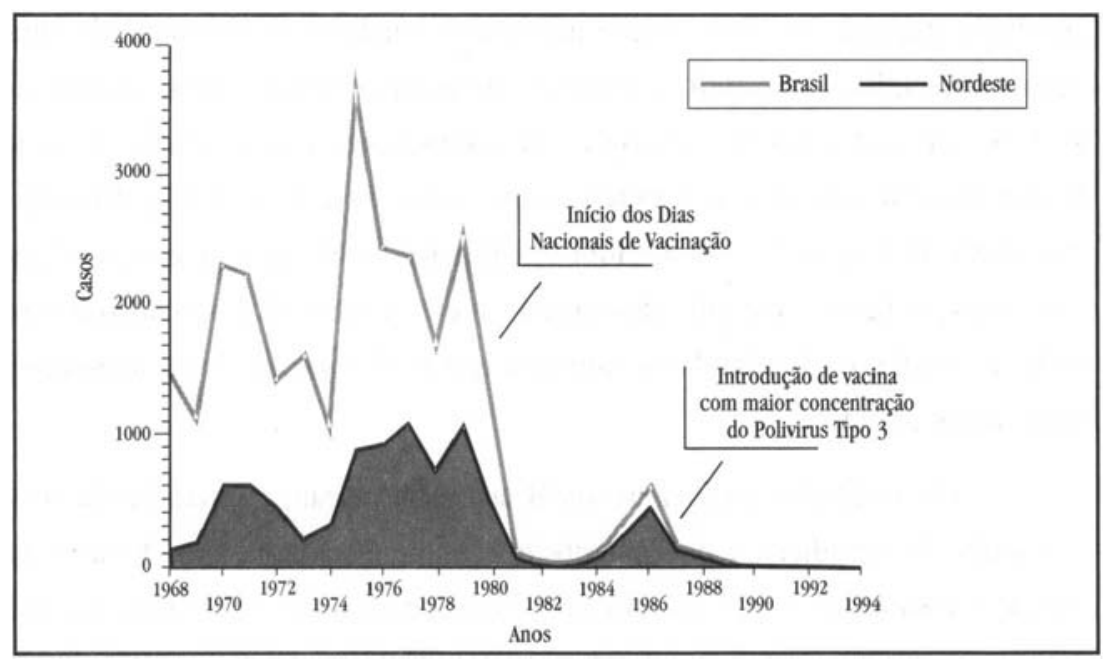

Atualmente, as ações de vigilância estão voltadas para a ocorrência de paralisias flácidas agudas (PFA), com o objetivo de detectar, o mais rapidamente possível, situações que possam sugerir a presença de poliovírus selvagens circulantes na região das Américas. A OPAs vem apoiando os países do continente na utilização de indicadores padronizados de PFA e na identificação das características antigênicas de poliovírus de origem vacinal, isolados a partir dos casos investigados. A OPAs também 
apóia o Brasil no desenvolvimento do Plano Nacional de Contenção de Poliovírus em Laboratórios, como parte do processo que antecede a erradicação global da poliomielite.

\section{Doenças transmissíveis com tendência declinante}

Resultados expressivos têm sido alcançados com relação a várias doenças transmissíveis para as quais se dispõe de instrumentos eficazes de prevenção e controle. Muitos desses resultados devem-se ao eficiente desempenho do PNI, para o qual a OPAS colabora estreitamente, inclusive por intermédio do Fundo Rotativo para a aquisição de vacinas não produzidas no Brasil.

A transmissão do sarampo está interrompida desde o final de 2000, e a taxa de incidência do tétano neonatal encontra-se muito abaixo do patamar estabelecido para a sua eliminação como problema de saúde pública (um caso por 1000 nascidos vivos). A raiva humana transmitida por animais domésticos também teve muito reduzida a sua incidência e concentração de casos, podendo-se prever que seja eliminada em futuro próximo. Outras doenças que integram esse grupo são as seguintes: 1) difteria, coqueluche $e$ tétano acidental, também evitáveis por imunização; 2) doença de Chagas e hanseníase, objeto de intensas ações de controle nos últimos anos; 3) febre tifóide, doença que pode ser reduzida por meio de melhorias sanitárias; 4) oncocercose, filariose e peste, de ocorrência focalizada.

Para 0 conjunto de algumas doenças imunopreveníveis (sarampo, tétano acidental e neonatal, coqueluche e difteria), o impacto das ações pode ser visualizado com clareza. Em 1980, ocorreram 153.128 casos dessas doenças, incidência essa que, vinte anos depois, havia sido reduzida para apenas 3.124 casos. Ainda mais relevante foi 0 impacto sobre o número de óbitos, reduzidos de 5.495 para 277 , no mesmo período. Análise similar 
poderia ser feita para as demais doenças do grupo, que também apresentaram reduções na incidência, na mortalidade e na ocorrência de seqüelas, com impacto significativo na qualidade de vida.

\section{Sarampo}

Historicamente, o sarampo, associado à desnutrição, representou importante causa de mortalidade em crianças no Brasil. 0 estudo multicêntrico realizado pela Opas na década de 1960, em cidades da América Latina - entre elas São Paulo, Recife e Ribeirão Preto - mostrou que o sarampo era a principal causa de morte entre um e quatro anos de idade, nas três cidades brasileiras incluídas na pesquisa. Até a primeira metade da década de 1980, ocorreram no Brasil repetidas epidemias de sarampo, com centenas de milhares de casos registrados, que causaram 11.354 mortes, somente entre 1980 e 1984.

A vacinação sistemática contra o sarampo, em âmbito nacional, foi introduzida no Brasil em 1973, no âmbito do então instituído Programa Nacional de Imunização. Os esforços realizados nas décadas de 1970 e 1980, utilizando as estratégias de rotina e de campanha, foram insuficientes para manter a doença sob controle, em função da dificuldade de alcançar e de manter coberturas de vacinação elevadas e homogêneas no país. Além disso, houve de início certa controvérsia na definição da idade mínima para iniciar a vacinação, devido à variabilidade na persistência de anticorpos maternos que neutralizam a resposta sorológica à vacina. Essa questão foi em parte resolvida no início da década de 1980 , por meio de um estudo multicêntrico conduzido pela 0pas, que fixou tal idade em nove meses.

Uma abordagem mais agressiva para controlar o sarampo no Brasil foi estabelecida em 1992, baseada na vacinação em massa, por campanha nacional, de toda a população brasileira entre 9 meses e 14 anos de idade, independente de estado vacinal prévio. Pretendeu-se, assim, interromper 
bruscamente a transmissão da doença, considerando que, fora dessa faixa etária, não haveria um contingente de suscetíveis suficiente para manter a cadeia de transmissão. Dessa forma, a doença poderia ser eliminada até 0 ano de 2000 , mediante a vacinação sistemática das novas coortes infantis, complementada por rápidas operações de bloqueio de surtos, identificados por atividades de vigilância epidemiológica ativa. A campanha realizada em 1992 atingiu mais de 48 milhões de crianças na faixa etária alvo, equivalente à cobertura de $96 \%$. Nos quatro anos seguintes, de fato, a incidência do sarampo foi drasticamente reduzida (Gráfico 9).

Gráfico 9 - Incidência de sarampo e estratégias de controle. Brasil e região Sudeste - 1968-2000

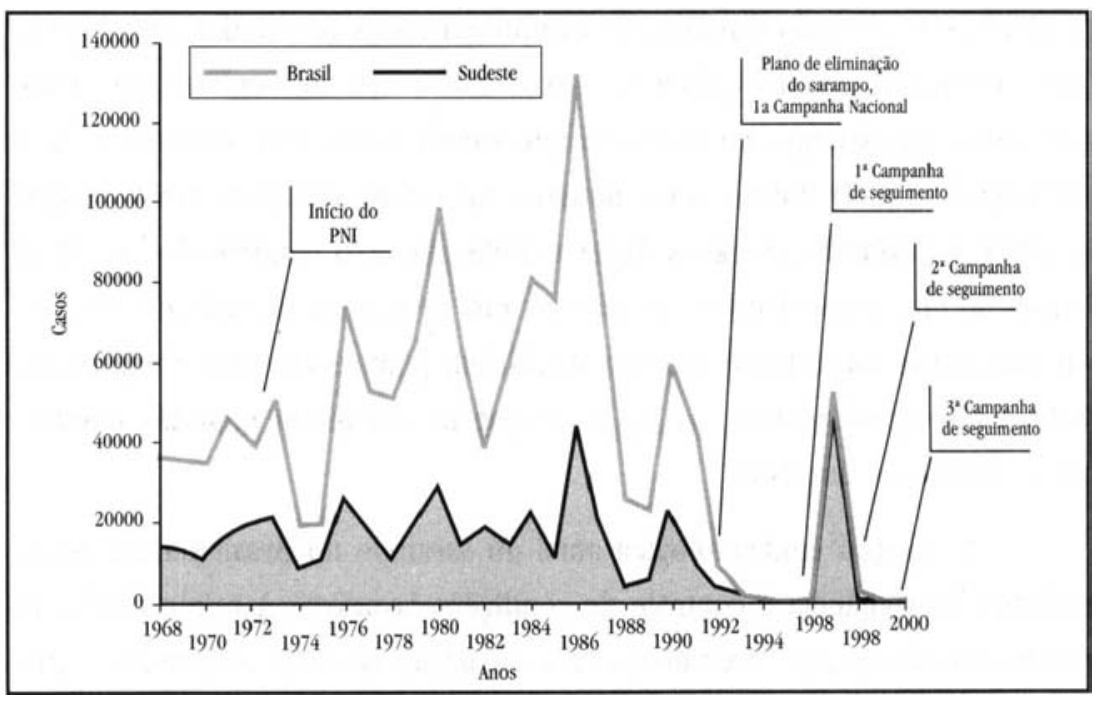

Por vários motivos, porém, o êxito inicial alcançado não foi acompanhado, em escala correspondente, pelas outras ações previstas, entre elas a elevação da homogeneidade na cobertura vacinal de rotina e a realização de uma campanha de 'seguimento' em 1995, que contribuiria para evitar a acumulação de susceptíveis. Essa campanha não atingiu resultados satisfatórios, o que condicionou a eclosão, em 1997, de uma epidemia inici- 
ada em São Paulo e que se expandiu para outros 18 estados, perfazendo 53.664 casos confirmados e 61 óbitos. Uma nova campanha de seguimento foi realizada ainda em 1997, tendo sido também revisadas as estratégias referentes à meta de eliminação.

Neste mesmo ano, a vigilância da rubéola foi integrada à vigilância do sarampo, a fim de tornar o sistema mais sensível. A integração passou a ocorrer de forma plena em 1999, com notificação imediata, coleta de amostras e investigação de todos os casos suspeitos de rubéola e sarampo. Em 1999, uma força-tarefa foi criada com o objetivo de garantir a execução, em cada estado, das ações de vigilância epidemiológica e de vacinação preconizadas no programa. Apoiado pela OpAs, esse grupo é formado por 27 técnicos realizando trabalho de campo em todos os estados brasileiros. Como resultado desses esforços, desde 2000 não há registro de casos autóctones de sarampo no Brasil, o que sugere tenha sido interrompida a circulação viral. 0 último surto ocorreu no estado do Acre, em fevereiro de 2000, totalizando 15 casos. Houve ainda um caso confirmado, no Mato Grosso do Sul, em novembro do mesmo ano. 0 sistema de vigilância detectou dois casos importados em São Paulo, em janeiro de 2001 e março de 2002, ambos procedentes do Japão, o que desencadeou medidas imediatas e eficazes de controle.

A situação epidemiológica atual do sarampo no Brasil requer ações eficientes de vigilância e controle de condições favoráveis à reintrodução da transmissão da doença. Recomenda-se a vacinação de todas as pessoas, entre um e 39 anos de idade, que se dirijam a países onde houve recente circulação do vírus do sarampo. Devem estar vacinados, também, os profissionais que mantêm contato com viajantes oriundos dessas áreas, tais como agentes de turismo, motoristas de táxi, agentes da polícia federal, aeroviários e profissionais de saúde. Com relação à vigilância epidemiológica, a prioridade atual é assegurar a detecção precoce e a investigação de casos importados para que as ações de controle sejam instituídas de forma imediata e eficaz. 


\section{Raiva humana}

Até 0 ano de 1973, atividades sistematizadas de prevenção e controle da raiva eram realizadas apenas em algumas cidades brasileiras, como São Paulo e Rio de Janeiro. Nesse ano, foi criado o Programa Nacional de Profilaxia da Raiva (PNPR), mediante convênio firmado entre os ministérios da Saúde e da Agricultura, a Central de Medicamentos e a Opas. Seu objetivo geral era eliminar a raiva humana, controlando a doença nos animais domésticos e assegurando o tratamento profilático das pessoas expostas a animais raivosos.

0 programa instituiu normas técnicas nacionais para controlar a doença, padronizou a produção, o controle e o suprimento dos imunobiológicos utilizados, instituiu campanhas anuais de vacinação de animais domésticos, ampliou a rede de laboratórios, promoveu a capacitação de profissionais e estabeleceu um sistema de vigilância epidemiológica que previa o fluxo mensal de informações padronizadas, do nível estadual para o nacional. Essas atividades foram implantadas gradualmente, inicialmente nas áreas urbanas das capitais e regiões metropolitanas, para então se estender às cidades do interior e à zona rural. Em 1977, o programa estava atuando em todos os estados.

As ações do PNPR reduziram o número de casos de raiva humana, sobretudo nas regiões Sudeste e Sul, onde existia melhor estrutura técnica e operacional. Em 1980, foram registrados no país 173 casos de raiva humana e, em 2001, o número de casos confirmados estava reduzido a 21 (Gráfico 10). Na média dos últimos cinco anos (1997-2001), $71 \%$ dos casos ocorreram nas regiões Norte e Nordeste, e os restantes $29 \%$ nas regiões Sudeste e Centro Oeste. Na região Sul, desde 1987 não há registro de casos de raiva humana. 
Gráfico 10 - Casos de raiva humana. Brasil - 1975-2001

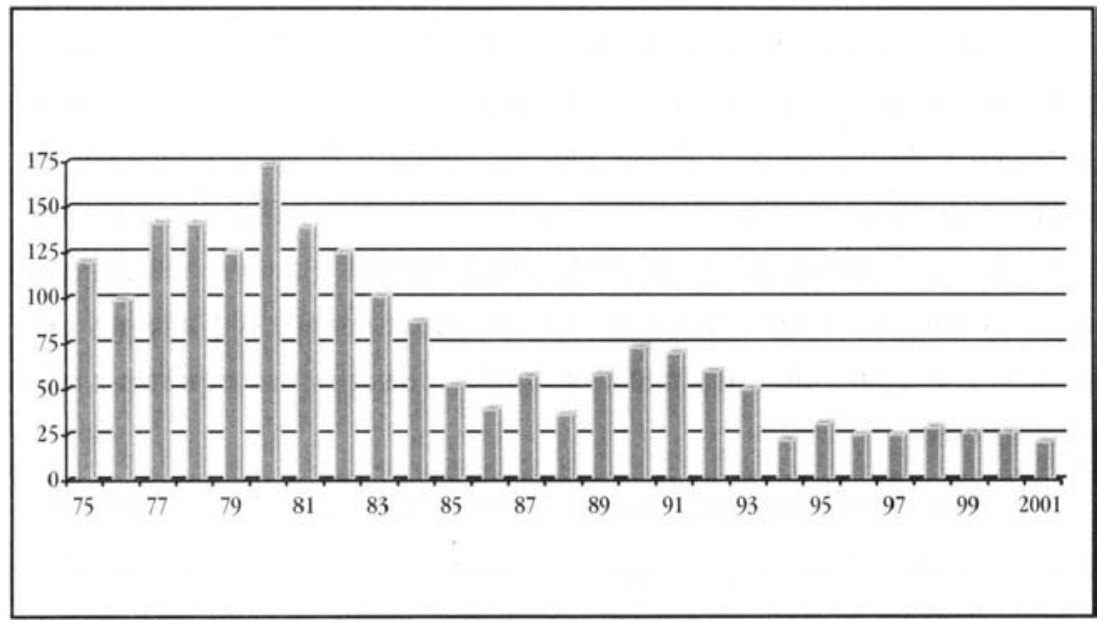

No que se refere à incidência em animais transmissores, foram notificados 1.320 casos de raiva no período de 1980 a 2000 , dos quais $1.222(92,6 \%)$ corresponderam a 13 espécies diferentes de animais identificados. Predominaram os casos diagnosticados em cães $(79,6 \%)$, morcegos $(6,2 \%)$ e gatos $(3,6 \%)$. Nos últimos cinco anos, aumentou a participação dos casos de raiva diagnosticados em macacos, que nos anos de $2000 \mathrm{e}$ 2001 passaram a ocupar a segunda posição. 0 ciclo urbano de transmissão permanece o mais importante ( $83,2 \%$ dos casos), seguindo-se o ciclo silvestre $(9,1 \%)$, que inclui a transmissão por morcegos, e o ciclo rural $(0,3 \%)$.

0 Ministério da Saúde instituiu um plano de eliminação da raiva humana transmitida por cães, que vem sendo implementado segundo objetivos e metas estabelecidas nos níveis federal, estadual e municipal. Esse plano consiste na intensificação e reorientação das atividades componentes das grandes linhas de ação tradicionais do PNPR, incluindo a vacinação sistemática de cães, o tratamento padronizado de pessoas expostas, o diagnóstico laboratorial, a captura e eliminação de cães errantes, a vigilância epidemiológica e a educação em saúde. 


\section{Doença de Chagas}

Deve-se ao cientista brasileiro Carlos Chagas, em 1909, a descrição completa dessa doença, incluindo o agente causal, o mecanismo natural de transmissão, o quadro clínico e sua evolução. 0 mesmo autor indicou, ainda, os determinantes primários da enfermidade, "todos eles relacionados às precárias condições de vida, e particularmente de habitação, das populações sob risco", 1 com o que apontava possíveis soluções.

0 controle físico pela melhoria da habitação era então a única alternativa, mas a extensão da área infestada tornava inviável sua adoção em larga escala, pelo alto custo e dificuldade de superar questões fundiárias, ligadas à posse da terra. Em 1945, foi introduzido no país o inseticida DDT, mas os ensaios iniciais logo frustraram a expectativa de sua possível eficácia no combate aos vetores da doença de Chagas. No ano de 1947, um novo inseticida clorado, o isômero gama do hexaclorociclohexano-HCH, mostrou em laboratório sua alta ação tóxica para triatomíneos. No ano seguinte, Dias e Pellegrino, no Brasil, e Romaña e Abalos, na Argentina, comprovaram, em condições de campo, a eficácia do $\mathrm{HCH}$ no combate aos vetores da doença de Chagas.

Em função desses resultados, o governo federal instituiu, em 1950, a Campanha contra a Doença de Chagas, sob a responsabilidade do Serviço Nacional de Malária. As primeiras ações se desenvolveram ao longo do vale do Rio Grande, na divisa dos estados de Minas Gerais e São Paulo, porém as etapas seguintes não tiveram a continuidade e a contiguidade espacial necessárias. Por um longo período, a doença não foi reconhecida como prioridade, pois os esforços se concentravam no combate à malária, doença aguda que limitava o projeto de desenvolvimento do país, dificultando a ocupação de novos espaços e a expansão das fronteiras agrícolas. A doença de Chagas, ao contrário, manifestava-se de forma insidiosa, em áreas rurais de menor expressão econômica, afetando grupos sociais sem poder reivindicatório.

\footnotetext{
${ }^{1}$ Chagas, C. Nova espécie mórbida do homem produzida por um Trypanozoma (Scbizotripanum cruzi). Nota prévia. Brazil-méd., 23(16): 161, 1909.
} 
Em 1975, tendo sido erradicada a malária nas regiões Nordeste, Sudeste e em parte da Centro-Oeste, maior atenção e recursos voltaram-se à doença de Chagas. 0 programa de controle foi então revisto, normalizado e redimensionado para ter alcance nacional, sendo estruturado a partir do modelo de operações de campo contra a malária. A informação epidemiológica até então produzida era dispersa, e os dados pouco uniformes e comparáveis, o que justificou a realização de dois amplos inquéritos nacionais, um de soroprevalência da infecção humana e outro entomológico, para delimitar a área de risco de transmissão vetorial da doença.

0 inquérito sorológico foi concluído apenas em 1980, tendo abrangido todos os municípios, exceto os do estado de São Paulo. A soroprevalência na população rural brasileira foi estimada em $4,2 \%$, com taxas máximas nos estados do Rio Grande do Sul e Minas Gerais (8,8\%). A distribuição por idade mostrou importante transmissão ativa, revelada pela soroprevalência de 2,2 \% no grupo até 2 anos de idade e de $10,6 \%$ na população de 5 a 14 anos, além de altas taxas entre os 15 e 49 anos de idade, que correspondiam ao perfil esperado.

0 inquérito vetorial, completado em 1983 já durante as operações de rotina do programa, compreendeu a captura de triatomíneos em domicílios de mais de 2.200 municípios, em 18 estados brasileiros. Foram encontradas, no domicílio ou no peridomicilio, 17 espécies do vetor, com distinta importância e participação na transmissão da doença. Pela frequiência das capturas e das taxas de infecção natural por Trypanosoma cruzi, cinco espécies foram consideradas, à época, responsáveis pela veiculação da doença no ambiente domiciliar. Uma delas - Triatoma infestans - merecia atenção especial, por suas características de antropofilia, capacidade vetorial e larga distribuição.

Os resultados desses dois estudos fundamentaram um desenho de área endêmica ou com risco de transmissão vetorial, que excluía, a rigor, apenas a Região Amazônica e o estado de Santa Catarina. 0 inseticida empre- 
gado de início foi o mesmo HCH usado por Dias e Pellegrino, mas em concentração maior de ingrediente ativo (30\% de isômero gama). A partir de 1982, foram introduzidos os piretróides de síntese, que, por sua ação desalojante, ofereciam muito maior eficácia, além de menor toxicidade para o homem.

As características epidemiológicas próprias da doença de Chagas e a tecnologia disponivel para combatê-la fazem do vetor 0 único elo na cadeia de transmissão natural em que se pode intervir. Assim, tende-se a julgar que seja baixa a vulnerabilidade da doença de Chagas a ações de controle. No entanto, a experiência mostrou o contrário. Atributos muito particulares do vetor permitem que se vislumbre interromper a transmissão da doença em quase todas as situações e em prazo relativamente curto. Os triatomíneos têm pequena mobilidade, suas populações são estáveis e se repõem muito lentamente, e todos os estádios estão presentes no mesmo ecótopo. Ademais, as dificuldades mecânicas para a transmissão determinam que a densidade vetorial no domicílio deva ser grande.

Desse modo, passados 25 anos desde que se inauguraram ações de controle químico no país, a transmissão vetorial é hoje residual, a não ser pela infestação importante por Triatoma brasiliensis em alguns municípios onde as atividades foram interrompidas, ou estão reduzidas a intervenções pontuais ou esporádicas. Os dados de entomologia por si sós mostram o grande impacto havido no controle da doença de Chagas no país. Confirmam isso os inquéritos sorológicos que vêm sendo realizados, desde 1989, na população escolar de 7 a 14 anos, mostrando taxas de soro-reagentes entre 0,15 a $0,2 \%$.

Desde 1991 está em funcionamento a Comissão Intergovernamental para Doença de Chagas, constituída pelos ministérios da Saúde dos países do Cone Sul (Brasil, Bolívia, Chile, Paraguai e Uruguai) e secretariada pela Opas. Como resultado de criteriosa avaliação dos avanços realizados nesses países, a Comissão certificou a eliminação do $T$. infestans em oito estados 
brasileiros, e outros dois - Piauí e Tocantins - estão incluídos para serem certificados em 2002.

Os dados sobre internações hospitalares apresentam limitações para análise de tendências da doença de Chagas, pois ocorrem na fase crônica da doença, exceto em casos excepcionais. Ainda assim, observa-se progressiva redução de internações por essa causa entre 1990 e 1997. Chama a atenção que essa tendência não tenha se mantido nos dois anos seguintes, o que pode dever-se a fatores relativos à coleta dos dados, oferta ou acesso aos serviços, bem como a maior apuro diagnóstico na fase crônica indeterminada da doença. Os dados de mortalidade também indicam tendência de queda acentuada e consistente, mesmo que, no caso da doença de Chagas, a morte seja quase sempre tardia. Entre 1980 e 1999, a taxa de mortalidade específica da doença declinou de 5,2 para 3,2 óbitos por 100 mil habitantes (Gráfico 11).

Gráfico 11 - Coeficiente de mortalidade específica por doença de Chagas. Brasil - 1980-1999

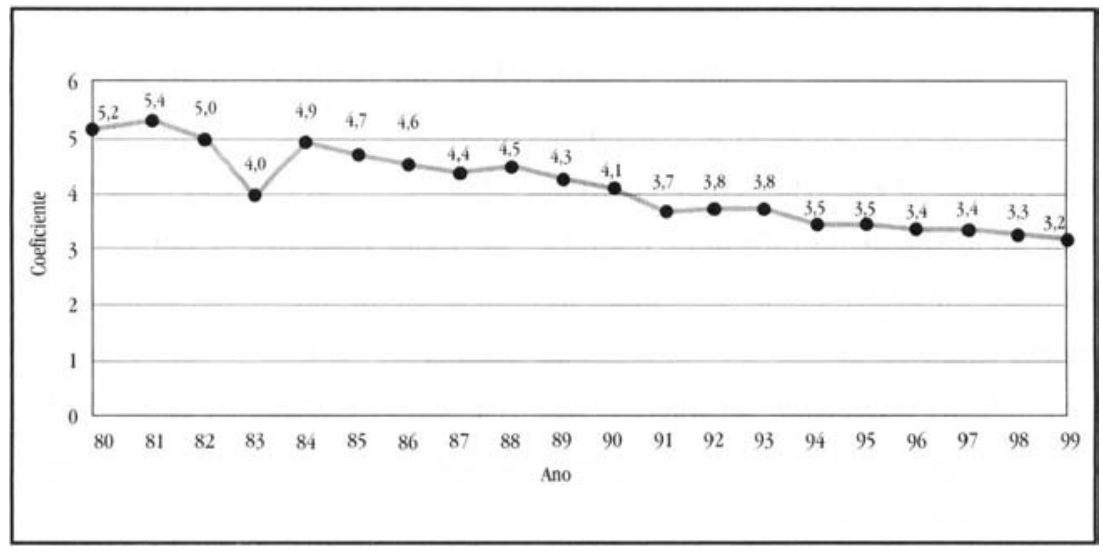

Fonte: MS. Funasa. CENEPI.

Não obstante o inegável o sucesso do programa brasileiro de controle da doença de Chagas, cabe ressaltar a superveniência de fatores socioeconômicos que contribuíram para esse resultado. Em algumas áreas inicialmente endêmicas, houve melhoria significativa das condições de habita- 
ção, em função de algum grau de desenvolvimento econômico. De outra parte, o rápido processo de urbanização do país, nas últimas décadas, provocou 0 êxodo de populações rurais que estavam mais expostas à transmissão vetorial.

\section{Hanseníase}

A partir de 1912, o problema da hanseníase passou a ser reconhecido pelas autoridades sanitárias que, em vários estados, oficializaram 0 isolamento compulsório dos doentes. Em 1920, com a criação do Departamento Nacional de Saúde Pública, foi instituída a Inspetoria de Profilaxia da Lepra, que iniciou a realização de censos leprológicos, nos estados endêmicos, e o tratamento dos doentes com o óleo de chaulmoogra. Em 1935, um plano de ação mais abrangente estendeu a assistência aos familiares dos pacientes, com 0 apoio das Ligas de Caridade. Em 1941, foi criado o Serviço Nacional de Lepra (SNL) e, em 1946, o Instituto de Leprologia, que exerceu importante papel nas áreas de pesquisa e de orientação técnica às ações nacionais.

Com o advento da sulfona, em 1943 , e de novos conhecimentos sobre a doença, o tratamento passou a ser feito ambulatorialmente, nos 'dispensários de lepra', e desenvolveu-se um modelo de vigilância epidemiológica da doença. Para gerenciar o programa foi criada, em 1959, a Campanha Nacional de Lepra, que expandiu a rede de dispensários, mobilizando sobremaneira a comunidade científica do país. Já no final dos anos de 1950, porém, havia um sentimento de mudança do atendimento especializado, que deveria passar dos dispensários para a rede geral de serviços. Somente no final da década seguinte, esse pensamento canalizou-se para 0 modelo médico-sanitário de atendimento, inspirado na racionalidade técnica das idéias de planejamento de saúde. Em 1975, o Serviço Nacional de Lepra foi substituído pela Divisão Nacional de Dermatologia Sanitária (DNDS), que publicou, no ano seguinte, instruções normativas descentralizando as atividades do programa de controle da hanseníase. 
0 programa brasileiro de eliminação da hanseníase teve como um marco importante 0 ano de 1985, quando se processou uma intensa avaliação da situação e a elaboração de recomendações que vêm sendo implementadas desde então. Entre elas, destacam-se a descentralização das ações para toda a rede da saúde, a capacitação de recursos humanos em todos os níveis, a criação e ampliação de centros de referência, a implantação da poliquimioterapia e o desenvolvimento de campanhas de educação em saúde. Em nova avaliação realizada em 1991, verificou-se que a detecção de casos havia aumentado em mais de $35 \%$, o número de incapacitados entre os casos novos de hanseníase diminuíra e o esquema de poliquimioterapia estava sendo utilizado em todo o país.

Nesse mesmo ano, a OMS realizou a $44^{2}$ Assembléia Mundial de Saúde, na qual os representantes nacionais, motivados pelos resultados da implantação do novo esquema terapêutico, propuseram a eliminação da hanseníase como problema de saúde pública, tendo como meta reduzir, até o final do ano 2000, a taxa de prevalência da doença a menos de um doente para cada 10.000 habitantes. Tal proposta significava, no caso brasileiro, reduzir em 17 vezes a taxa de prevalência estimada, meta essa que seria impossivel ser atingida no prazo estabelecido.

Não obstante, intensificaram-se os esforços do programa de controle, mobilizando recursos institucionais nos níveis federal, estadual e municipal. Ao final do ano 2000 , a taxa de prevalência da doença fora reduzida em $80 \%$, enquanto aumentou em $35 \%$ a detecção de casos (Gráfico 12), indicando a ampliação de cobertura do programa. 0 novo prazo para o cumprimento da meta foi fixado para o final do ano de 2005, durante a III Conferência Mundial de Eliminação da Hanseníase, realizada em 1999, na Costa do Marfim. 
Gráfico 12 - Coeficiente de prevalência de hanseníase. Brasil - 1985 - 2001

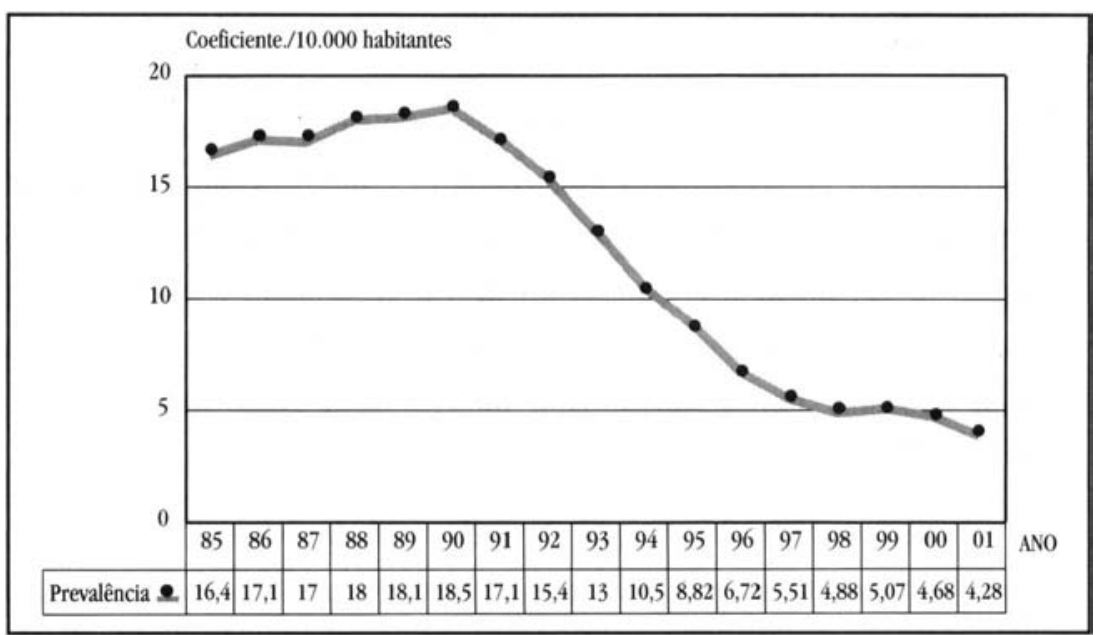

Em novembro de 2001, o governo brasileiro lançou o Plano de Mobilização para a Intensificação das Ações para a Eliminação da Hanseníase, centrado praticamente em seis eixos: 1) mobilização técnica, política e social em torno das metas de eliminação da hanseníase; 2) descentralização das ações e mudança do modelo de atenção, com reorganização de serviços; 3) melhoria da vigilância epidemiológica e dos sistemas de informação; 4) ampliação e qualificação da rede de laboratório e diagnóstico; 5) garantia de assistência farmacêutica, com distribuição descentralizada e acompanhamento dos estoques; 6) capacitação e desenvolvimento de recursos humanos.

Esse plano vem sendo implementado pelo Ministério da Saúde, em cooperação com o Conselho Nacional de Secretários Municipais de Saúde e a OPAs, com ênfase na melhoria da informação epidemiológica sobre hanseníase em municípios prioritários, para monitorar de forma mais acurada o processo de eliminação da doença. Como evidência desse compromisso, o Ministério da Saúde do Brasil recebeu, em janeiro de 2002, a presidência da Aliança Global contra a Lepra, cargo de responsabilidade fundamental para a condução mundial dos esforços destinados a alcançar as metas de eliminação da hanseníase apoiadas e recomendadas pela OMS para o ano de 2005. 


\section{Doenças transmissíveis com quadro de persistência}

Algumas doenças transmissiveis apresentam quadro de persistência ou de redução em período ainda recente, configurando uma agenda inconclusa nessa área. Seu controle tem como foco importante de atenção as ações de diagnóstico e tratamento de casos, visando a interromper a cadeia de transmissão. Para tanto, é necessário fortalecer estratégias recentemente adotadas, que prevêem maior integração de ações de prevenção e controle na rede assistencial.

A manutenção da situação de endemicidade desse grupo de doenças está relacionada, em grande parte, a fatores determinantes que transcendem as ações típicas do setor saúde, tais como a urbanização acelerada sem adequada infra-estrutura urbana, as alterações do meio ambiente, a ampliação de fronteiras agrícolas, os processos migratórios e as grandes obras de infra-estrutura (rodovias e hidroelétricas); portanto, seu controle depende de ações multissetoriais.

Entre as doenças incluídas no grupo, destacam-se as hepatites virais - especialmente as hepatites $\mathrm{B}$ e $\mathrm{C}$ - e a tuberculose, em função de apresentarem altas taxas de prevalência, ampla distribuição geográfica $e$ potencial evolutivo para formas graves, por vezes letais. Ressalve-se os resultados favoráveis que têm sido alcançados na redução da mortalidade pela tuberculose, com a disponibilidade de tratamento específico de alta eficácia. A implantação universal da vacinação contra a hepatite $B$, inclusive em adolescentes, no final dos anos 1990, também tende a produzir, em médio prazo, impacto positivo na prevenção das formas crônicas.

Ainda que a distribuição geográfica da leptospirose seja mais restrita às áreas que oferecem condições ambientais adequadas para a transmissão, sua relevância para a saúde pública resulta do grande número de casos que ocorrem nos meses mais chuvosos e da sua alta letalidade. As 
meningites também se inserem neste grupo de doenças, destacando-se as infecções causadas pelos meningococos B e C, que apresentam níveis importantes de transmissão e taxas médias de letalidade - acima de $10 \%$. Entretanto, tem-se observado significativa redução na ocorrência da meningite causada por $H$. influenzae tipo $\mathrm{B}$, possivelmente em consequiência da utilização, a partir de 1999, de uma vacina de comprovada eficácia em menores de um ano.

Esse grupo inclui também a leishmaniose, nas formas visceral e tegumentar, cuja prevalência mantêm-se em níveis elevados, e com expansão da área geográfica de ocorrência; e ainda a esquistossomose, em geral associada a modificações ambientais introduzidas pelo homem, a deslocamentos populacionais originados de áreas endêmicas, e à deficiente infra-estrutura de saneamento básico.

A malária, que até recentemente apresentava níveis de incidência persistentemente elevados na Região Amazônica, que concentra mais de $\mathbf{9 9 \%}$ dos casos registrados no país, a partir de 1999 passou a apresentar reduções acentuadas nestas taxas (acima de $40 \%$, em média), estimando-se que em 2002 sejam detectados menos de 300 mil casos, patamar que não era atingido desde 0 início dos anos 1980.

A febre amarela, após a eliminação do seu ciclo urbano em 1942, vem apresentando ciclos epidêmicos de transmissão silvestre, como ocorrido em 2000 (Goiás) e 2001 (Minas Gerais). Contudo, apesar da ampliação da área de transmissão para estados e municípios situados fora da área endêmica (Região Amazônica), tem sido observada uma redução na incidência a partir do ano 2000 até o presente momento. A possibilidade de reintrodução do vírus amarílico no ambiente urbano, pela ampla dispersão do Aedes aegypti, tem motivado uma intensa atividade de vacinação, que registrou mais de 60 milhões de doses aplicadas entre 1998 e 2002 . Na medida em que foram identificados eventos adversos graves associados a essa vacina, a estratégia inicial de vacinação universal teve de ser ajustada 
para uma cobertura mais focalizada - em toda a área de circulação natural do vírus e também na área de transição.

\section{Malária}

Desde o final do século XIX, a malária foi objeto de investigação por parte da comunidade médica e científica do país, que deu importante contribuição ao conhecimento da epidemiologia e controle da doença. Em 1905, Oswaldo Cruz, animado com a tese de douramento de Carlos Chagas, convoca-o a participar de trabalho que visava a conter epidemia de malária no município de Itatinga, estado de São Paulo. Lá se realiza a primeira campanha bemsucedida de controle da malária no país. Chagas introduz procedimentos que passaram a ser adotados rotineiramente, como o combate aos mosquitos adultos pela queima de piretro, produto à base de enxofre. No ano de 1922, a Fundação Rockefeller passou a desenvolver, na Baixada Fluminense, estudos sistematizados sobre a malária, que corroboraram a proposta de Carlos Chagas de controle por meio do combate às formas aladas do vetor.

0 acontecimento seguinte, que marcou a história do controle da malária no país, foi a introdução, em 1930, do Anopbeles gambiae na região Nordeste. Esse achado teve grande repercussão, pela reconhecida competência transmissora da espécie, nativa da África. A decisão de erradicar 0 vetor tardou até 1939, quando foi criado o Serviço de Malária do Nordeste, com 0 apoio da Fundação Rockefeller. Tendo mobilizado extraordinários recursos e instituído rígida disciplina nas operações de campo, o programa atuou em toda a extensa área em que se distribuía o vetor, logrando eliminálo em dois anos. Esse feito notável antecedeu a descoberta do DDT, e o tratamento dos casos restringia-se ao uso de atebrina e quinina.

No início da década de 1940 deste último século, três instituições atuavam no controle da malária no Brasil, provendo cobertura quase integral à 'área malarígena': o Serviço Especial de Saúde Pública (SESP), na Amazônia; o Serviço Estadual de Malária, em São Paulo; e o Serviço Nacional de 
Malária, criado em 1941, no restante do país. Em 1945, chegaram ao país o DDT e a cloroquina, em substituição à atebrina. Com esses novos instrumentos e o êxito da experiência de erradicação do An. gambiae, pensou-se na possibilidade de erradicar a doença.

Na década de 1950, a área delimitada como endêmica de malária correspondia a mais de $84 \%$ do território brasileiro, ou aproximadamente 7,2 de milhões de $\mathrm{km}^{2}$. A doença era então prioridade absoluta entre os problemas de saúde pública do país, pelos danos que causava à expansão das fronteiras agrícolas na 'marcha para o interior', bem como ao escoamento de minérios e produtos agrícolas. Em 1956, foi instituída a Campanha de Erradicação da Malária (CEM), como agência autônoma que substituiu o Serviço Nacional de Malária. Essa iniciativa correspondeu ao compromisso assumido na XIV Assembléia Mundial da Saúde, que aprovou a erradicação da doença como meta a ser alcançada em escala mundial.

0 grande esforço empreendido a partir de então, pautado em rígidas normas de conduta técnica e de controle operacional e administrativo, produziu expressivos resultados, tendo a doença sido erradicada em muitas áreas das regiões Nordeste, Sudeste e Sul do país. Em 1970, a transmissão atingiu os mais baixos níveis até então registrados, concentrando-se os casos na região Norte, considerada 'área de erradicação a longo prazo'. As dificuldades para o controle na Amazônia eram atribuídas, de início, basicamente às condições operacionais existentes.

0 ano de 1970 marca também a iniciativa do governo federal de promover a ocupação da Região Amazônica por meio de projetos integrados de colonização (PIC) implantados ao longo de rodovias, existentes ou a serem construídas, com o objetivo de assentar 100.000 famílias. Essa iniciativa criou condições propícias à expansão da malária e ao agravamento da situação epidemiológica da doença, pelo ingresso de populações originárias de estados onde não havia transmissão de malária, pela antropização frequientemente predatória do ambiente natural e pela abertura de estradas, que favoreceram 0 
ingresso descontrolado de migrantes. Somou-se a isso a inadequação do modelo 'técnico-campanhista' clássico, diante dos padrões de transmissão próprios da Região Amazônica. A aplicação desse modelo era dificultada por fatores tais como: precariedade e caráter provisório das habitações, o que restringia o uso de inseticidas de ação residual no controle do vetor; complexidade operacional, que impedia o pronto diagnóstico e a instituição do tratamento dos casos; e transmissão freqüientemente extradomiciliar.

Com isso, resultou uma explosão da malária, em muitas áreas da Amazônia, em associação ao processo incontrolável de migração, à abertura de garimpos que acompanhou a ocupação da região, e às limitações do modelo de intervenção. Também era preocupante o risco de reintrodução da malária em áreas de onde a doença havia sido erradicada, mas que permaneciam receptivas e vulneráveis à transmissão, o que exigia uma atenta vigilância no restante do país.

$\mathrm{Na}$ prática, o reconhecimento de que o 'modelo da erradicação' não tinha aplicação universal levou a que, no primeiro momento, se passasse a considerar áreas de 'erradicação a curto prazo' e de 'erradicação a longo prazo', como se o cumprimento da meta fosse apenas 'uma questão de tempo'. Não se admitia ainda a necessidade de revisar os objetivos, o modelo de organização e as práticas seguidas. Novos caminhos foram buscados a partir do início dos anos 1980, explicitando-se formalmente objetivos que viriam a ser coincidentes com os propostos da Conferência Ministerial de Amsterdã, em 1992. Essa Conferência enunciou objetivos a serem alcançados, no controle da malária, relativos à prevenção da mortalidade e à redução da morbidade, bem como de perdas econômicas e sociais, mediante 0 progressivo fortalecimento das capacidades locais e nacionais.

As novas normas técnicas de trabalho, baseadas na estratégia global aplicada ao Brasil, podem ser sumariadas em: atenção primordial ao caso de malária, objetivando o diagnóstico precoce e o tratamento imediato, especialmente de casos graves, para prevenção de complicações que levem à 
morte; controle seletivo do vetor; mobilização social; e participação interinstitucional $\mathrm{e}$ intersetorial.

0 controle normalizado e assumido institucionalmente implicava mudanças de comportamento do pessoal técnico e de campo, que necessitaram de algum tempo para serem de fato incorporadas às rotinas de trabalho.

0 exame dos dados mais recentes indica predomínio crescente do número de casos na Amazônia legal, desde que foi controlada a malária na chamada 'área de erradicação a curto prazo' (Figura 1). No início dos anos 1980, a Região Amazônica apresentava aproximadamente 95\% dos casos e, nos últimos anos, 99,5\% dos registros conhecidos, sendo que a maior parte dos casos restantes adoeceu na Amazônia. É certo que a distribuição do grau de risco de adoecer por malária dentro da própria região era, como ainda hoje, bastante heterogênea.

Figura 1 - Áreas com transmissão de malária, segundo categorias de risco. Brasil - 2000

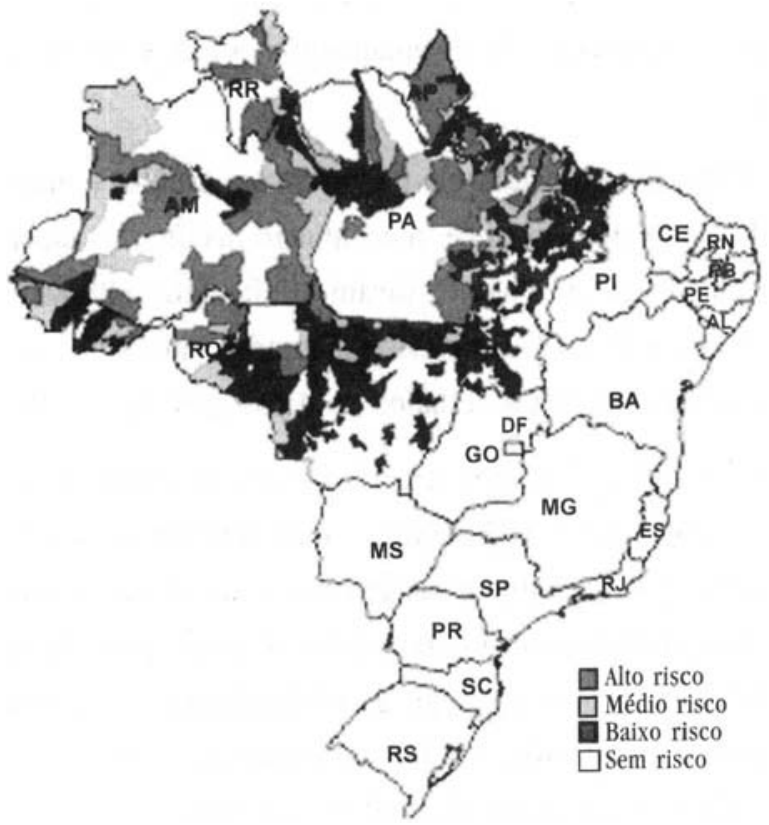

Fonte: MS. Funasa. Cenepr. 
No período 1980 a 1989 , a malária apresentou tendência claramente ascendente, atingindo 577.520 casos em 1989, correspondente ao coeficiente de incidência de 391,8 por 100.000 habitantes. Nos anos subseqüentes, o quadro se estabilizou em patamar superior a 500.000 casos/ ano, com importante redução, no período 1996-1997, para abaixo de 450 mil lâminas positivas anuais. Seguiu-se, então, grande recrudescimento da incidência, que atingiu as maiores cifras já registradas no país, com 637.472 casos em 1999 (incremento de $34 \%$ em relação a 1998), e 615.245 casos em 2000.

Tal situação levou a Fundação Nacional de Saúde a elaborar o Plano de Intensificação das Ações de Controle da Malária (PIAcM), lançado em julho de 2000. 0 plano garantiu a ampliação do acesso ao diagnóstico e tratamento, por intermédio da descentralização e da integração com as ações de atenção básica, e o melhor equacionamento das ações seletivas de controle vetorial. Além disso, possibilitou a implementação de importantes ações extra-setoriais, a partir do estabelecimento de normas específicas voltadas para a instalação de assentamentos rurais e de projetos de desenvolvimento.

A essas ações, desenvolvidas em parceria com estados e municípios, pode ser creditada, ao menos em parte, o acentuado declínio da malária que se observou no ano de 2001, quando foram conhecidos 388.807 casos, correspondentes a cerca de $40 \%$ dos casos registrados em 1999. Essa redução foi particularmente notável nos estados do Amazonas, Acre e Roraima.

Os dados de mortalidade por malária no país mostram, desde 1988 - quando foram registrados 1.168 óbitos - uma tendência consistente e progressiva de queda, que se manteve mesmo nos anos de maior incidência de casos. Isso corresponde à redução do número de casos por Plasmodium falciparum, coincidente com o emprego de novas drogas, a ampliação da rede de diagnóstico e tratamento e a incorporação dos serviços locais e permanentes de saúde a programa de controle da malária. 
A OpAs tem colaborado intensamente com as autoridades nacionais para controlar a malária no Brasil, bem como tem apoiado iniciativas conjuntas dos países da Região nesse sentido. Entre essas iniciativas, destacamse: a realização de reuniões entre países nas áreas de fronteira, a implementação da Rede Amazônica de Vigilância da Resistência às Drogas Antimaláricas e a realização de estudo multicêntrico para avaliar os efeitos da administração de uma nova droga antimalárica.

\section{Febre amarela}

Em 1901, estava comprovada a participação de Aedes aegypti como transmissor da febre amarela e, nos anos seguintes, estava fundamentada, no Brasil, a possibilidade de erradicar o vetor pela eficácia dos métodos usados por Ribas (1901), Pereira Barreto, Barros e Rodrigues (1903) e Oswaldo Cruz (1903 a 1908). Essa perspectiva orientou a atuação sanitária até o início da década de 1930, quando foi reconhecida a existência do ciclo silvestre de transmissão enzoótica entre macacos reservatórios do vírus nesse ambiente - com a participação de outros vetores (Haemagogus, Sabethes). A partir daí, realizaram-se esforços para desenvolver uma vacina, o que foi conseguido em 1937. Como resultado de persistentes ações de controle do vetor e de imunização da população suscetível em áreas de risco, a transmissão urbana da febre amarela foi interrompida em 1942, quando se comprovou o último caso, ocorrido em Sena Madureira, Estado do Acre.

Mesmo não sendo mais possível erradicar a febre amarela, já que a circulação do vírus se mantinha no ambiente silvestre, acreditava-se factível, no Brasil, a erradicação do seu vetor urbano (A. aegypti). De fato, apenas com o uso do petróleo no combate às formas larvárias, o vetor vinha sendo eliminado em extensas áreas do país. Com o advento de novos inseticidas, como o DDT, a erradicação tornou-se um objetivo mais claramente assumido, e as autoridades brasileiras passaram a advogar a necessidade de uma 
política continental para tal fim. Em 1947, o Conselho Diretor da Opas aprovou uma resolução nesse sentido, e vários países se integraram à tarefa de erradicar a doença.

Em 1955, na cidade de Santa Terezinha, estado da Bahia, foi identificado o último foco de $A$. aegypti no Brasil. No entanto, o país viria a ser reinfestado, em meados dos anos 1960 , quando foram encontrados focos disseminados do vetor na cidade de Belém, no Pará (1967) e na ilha de São Luis, Maranhão (1968). Desde então, o A. aegypti se dispersou de forma progressiva a todos os estados brasileiros, estando presente, atualmente, em mais de 3.500 municípios. Tendo a reinfestação pelo vetor atingido as regiões Norte e Centro-Oeste, onde a transmissão é endêmica, temeu-se a possibilidade de reurbanização da febre amarela, 0 que não veio a ocorrer até 0 presente.

A incidência da febre amarela silvestre se manifesta principalmente pela ocorrência de casos esporádicos, que escapam às medidas de vacinação sistemáticas, dirigidas à população residente em áreas endêmicas ou que para elas se deslocam. A intervalos variáveis, ocorrem epizootias, geralmente de cada cinco a sete anos, que repercutem na intensidade e abrangência da incidência de casos humanos. Na década de 1990, esses surtos corresponderam aos períodos de 1993-1994 e 1998-2001. 0 primeiro deles, concentrado no estado do Maranhão, atingiu seu ápice em 1993, com 83 casos registrados. O segundo se expandiu a partir da região Norte para a Centro-0este, com o pico de 85 casos em 2000, tendo atingido áreas onde não havia ocorrência de casos durante décadas. Considera-se que a incidência acumulada de casos neste último surto esteja refletindo, também, maior sensibilidade do sistema de vigilância para a deteç̧ão de formas leves da doença, especialmente no estado de Goiás.

0 aumento da circulação viral para além das áreas endêmicas manifestou-se pela ocorrência de surtos em Alto Paraíso, no estado de Goiás 
(final do ano de 1999), no oeste da Bahia (2000) e no centro-oeste de Minas Gerais (primeiro semestre de 2001). Houve também registro de epizootias, sem ocorrência de casos humanos, como no Rio Grande do Sul. Este quadro levou à ampliação da área considerada de transição, situada entre as áreas endêmica e livre de transmissão, que abrange as regiões a oeste dos estados do Piauí, Bahia, Minas Gerais, São Paulo, Paraná, Santa Catarina e Rio Grande do Sul (Figura 2).

Figura 2 - Febre amarela silvestre: áreas endêmicas, indenes e de transição. Brasil - 2001

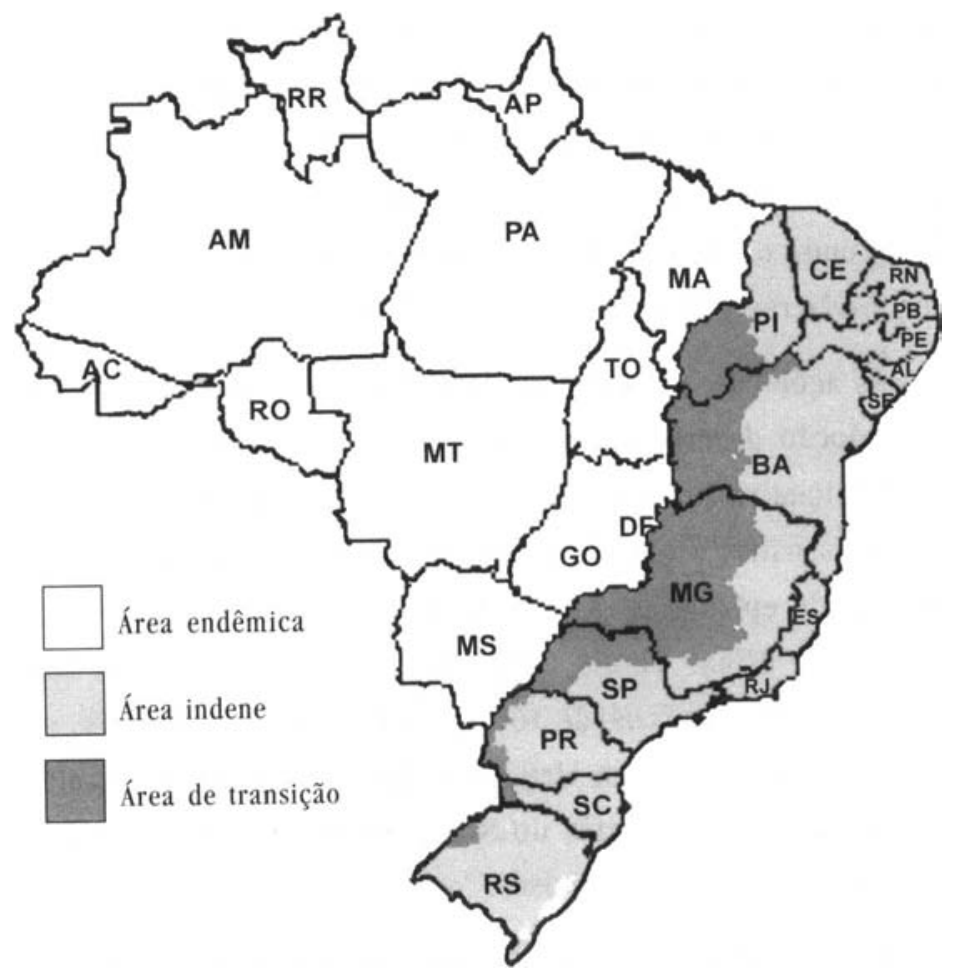

Fonte: MS. Funasa. CenepI 
Em abril de 1998, intensificou-se a aplicação da vacina antiamarílica na região endêmica, visando a proteger todos os moradores. Nesse esforço, foram vacinadas 12 milhões de pessoas, número quatro vezes superior à média de anos anteriores. Em 1999, ampliou-se essa ação para os residentes em áreas de difícil acesso, bem como para os residentes em áreas contíguas à região endêmica, como o Triângulo Mineiro e o norte-noroeste dos estados de São Paulo e Paraná. De 1998 a 2001, cerca de 60 milhões de pessoas foram vacinadas. Em ação articulada com órgãos de turismo e transporte, os viajantes que se deslocam para as áreas de risco têm sido continuamente alertados sobre a necessidade de vacinação prévia, cujo acesso foi ampliado a toda a rede de serviços saúde. Conseqüentemente à vacinação em massa, ocorreram alguns casos de febre amarela, que vieram a ser comprovados como associados à vacina. Em função disso, a vacinação sistemática ficou restrita à população residente nas áreas onde o risco da transmissão é superior ao risco de ocorrência de evento adverso grave associado à vacina.

As ações de vigilância epidemiológica foram intensificadas, com vistas à adoção de medidas tempestivas de bloqueio dos casos. A OpAS apoiou a iniciativa brasileira de desenvolver a vigilância sindrômica muito mais sensível e que permite detectar casos oligossintomáticos - e a vigilância de epizootias. A vigilância sindrômica vem sendo instituída nos estados de Minas Gerais, Amazonas e São Paulo. Foram realizados treinamentos de técnicos de todos os estados brasileiros, além de capacitações específicas em vigilância epidemiológica. Mediante articulação entre países na América do Sul, participaram desses treinamentos técnicos de diversos outros países.

Como resultado desse conjunto de ações, o número de casos registrados em 2001 ( 41 casos, dos quais 31 ocorreram no surto de Minas Gerais) reduziu-se a mais de $50 \%$ em relação ao ano anterior, tendência essa que se mantém em 2002, sem ocorrência de surtos de febre amarela. Ainda, como resultado do investimento do Brasil na 
produção e auto-suficiência nacional em imunobiológicos, a vacina antiamarílica produzida pela Bio-Manguinhos/Fiocruz (Rio de Janeiro) recebeu a certificação internacional da OMS de boas práticas de produção em 2001.

\section{Tuberculose}

A tuberculose atingia severamente a população brasileira no início do século XX. Não existia tratamento específico e a mortalidade era elevada. As ações de combate à enfermidade eram desenvolvidas pela sociedade civil, sendo exemplar o trabalho realizado pela Liga Brasileira contra a Tuberculose, fundada em 1900 por um grupo de intelectuais e médicos. Além de amplo trabalho educativo, a Liga construiu os primeiros dispensários para 0 diagnóstico e tratamento ambulatorial da tuberculose no país e, em 1927, iniciou a vacinação $\mathrm{BCG}$.

$\mathrm{Na}$ década de 1930, deu-se a incorporação institucional de novas tecnologias, como a baciloscopia, a abreugrafia, o pneumotórax e outras cirurgias torácicas. É apenas nessa década que o governo entra em ação, formando médicos especializados. Em 1941, foi criado o Serviço Nacional de Tuberculose (SNT) e, em 1946, instituída a Campanha Nacional Contra a Tuberculose, de égide governamental. A ênfase passou a ser a hospitalização dos pacientes e, com este objetivo, fundaram-se diferentes sanatórios, tendo por meta oferecer um leito por óbito registrado.

Em 1946, surgiram as primeiras drogas antibacterianas, a estreptomicina e o ácido paramino-salicílico (PAS). Finalmente, em 1951, surgiu a isoniazida, que revolucionou o tratamento e fez cair rapidamente a mortalidade. No Gráfico 13, ilustra-se a queda vertiginosa da mortalidade por tuberculose em um período de mais de um século, segundo registros no município do Rio de Janeiro, entre 1860 e 1977. 
Gráfico 13 - Mortalidade por tuberculose (por todas as formas). Rio de Janeiro - 1860-1977

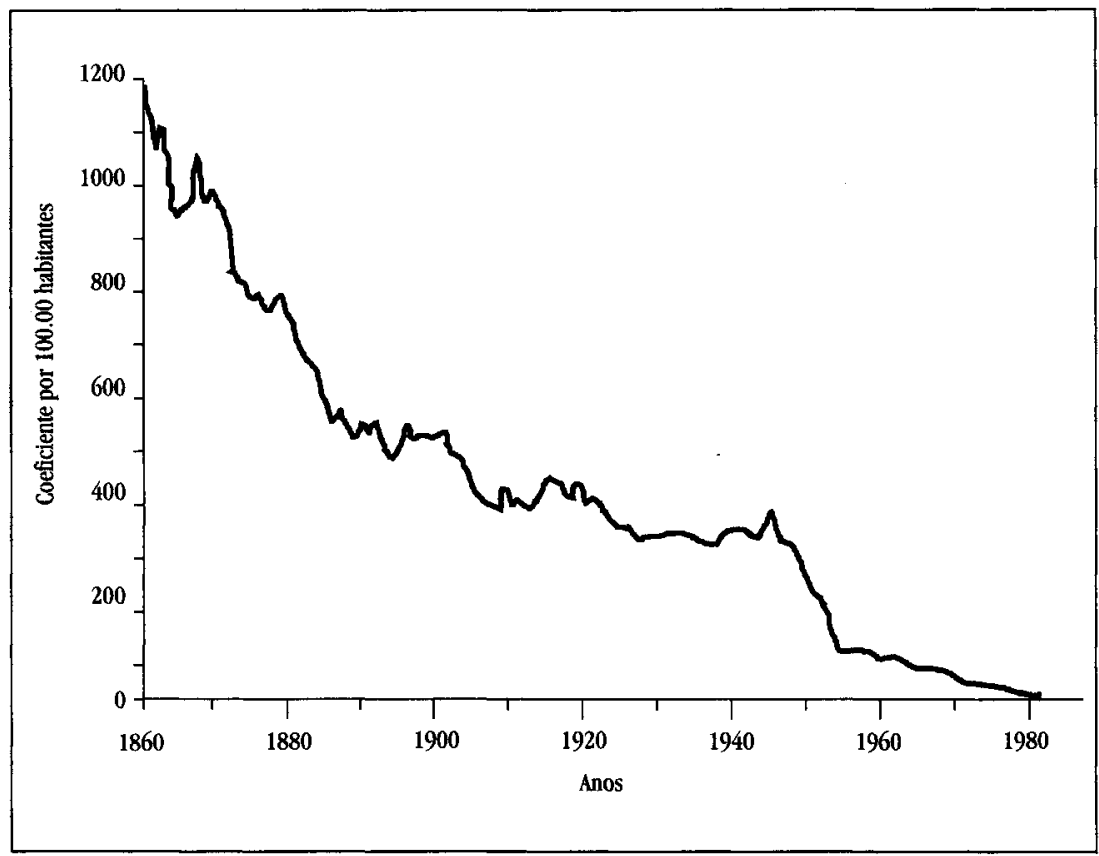

Fonte: Rufino Neto \& Pereira (1981).

Entretanto, a utilização inadequada dos medicamentos levou ao aparecimento da resistência bacteriana, prejudicando o êxito da quimioterapia.

Algumas experiências internacionais mostraram a importância de uma correta associação das drogas, sendo que uma experiência multicêntrica internacional, patrocinada pela União Internacional Contra a Tuberculose, levou ao estabelecimento de um esquema tríplice, com o emprego da estreptomicina, da isoniazida e do PAS.

o Brasil, por intermédio do Serviço Nacional de Tuberculose, foi um dos primeiros países a adotar um esquema padronizado com essas drogas para uso nacional. 0 esquema foi aplicado com a duração de 18 meses - encurtado, posteriormente, para 12 meses - tendo alcançado uma eficá- 
cia da ordem de $95 \%$ entre os que completavam o tratamento. Entretanto, a taxa de recidivas era elevada: cerca de $25 \%$ após a alta por cura.

Com o advento da quimioterapia mais simplificada, foi possível, a partir da década de 1960, a adoção de uma política de incremento do tratamento ambulatorial. Nessa época, a Fundação Sesp iniciou um programa de tratamento da tuberculose, em nível ambulatorial, com o esquema recomendado pelo SNT e realizou algumas investigações com base no tratamento supervisionado. 0s resultados foram bons, com taxa de abandono menor que $10 \%$ e de cura maior que $85 \%$ na coorte que iniciava o tratamento. Resultados igualmente satisfatórios foram obtidos em população indígena, com o tratamento ambulatorial conduzido pelo pajé, sob orientação médica. 0 esquema tríplice padronizado permitiu reduzir a resistência bacteriana às drogas. A taxa de resistência às duas ou três drogas reduziu-se, no Rio de Janeiro, de 66\%, em meados da década de 1950, para 30\% na década seguinte.

Na década de 1960, surgiram o etambutol e a rifampicina, droga esta que modificou o conceito de tratamento. A rifampicina foi usada no Brasil a partir de 1968 para tratar os casos reincidentes de tuberculose, com magníficos resultados, que possibilitaram a redução do tempo de duração do tratamento, de 12 para 6 meses. Entre 1972 e 1977, foi conduzido um ensaio controlado com o uso de rifampicina, isoniazida e pirazinamida, cujos resultados levaram à adoção do esquema de seis meses, em âmbito nacional. 0 Brasil foi o primeiro país a introduzir em nível nacional o esquema de curta duração.

Em 1979, estabeleceu-se um amplo programa de reorganização da luta antituberculose, com vistas à universalização do atendimento. 0 regime de tratamento passou a ser auto-administrado, combinando-se em uma só cápsula, a rifampicina e a isoniazida, com o objetivo de diminuir o risco de resistência. A descentralização do atendimento para unidades de saúde mais simplificadas propiciou drástica redução do número de leitos hospitalares. 
De outra parte, a simplificação dos procedimentos de diagnóstico e tratamento permitiu, em regime ambulatorial, a ampliação das atividades antituberculose e os cuidados por pessoal não especializado.

Com a absorção do InAMPs pelo Ministério da Saúde, unificaram-se as ações antituberculose em nível nacional e foi descentralizado o atendimento para o nível estadual e para os municípios maiores. Esses fatos permitiram uma redução do gasto, de 100 milhões de dólares por ano, para 60 milhões. A incidência da tuberculose, no começo dos anos 1980, era de cerca de 80 a 85 mil casos novos por ano. Em 1990, foi extinta a Campanha Nacional Contra a Tuberculose.

Até 1988, observou-se uma redução da incidência de tuberculose. Contudo, nesse período teve início a epidemia de Aids, que veio a influenciar a epidemiologia da tuberculose. Na década de 1990, verificou-se um aumento da taxa de abandono do tratamento auto-administrado e a incidência não mostrou tendência de declínio, enquanto a mortalidade continuou a diminuir. A taxa de resistência primária, em pesquisa de 1996, mostrou-se da ordem de $10 \%$, com menos de $2 \%$ de resistência à isoniazida e à rifampicina. No final da década de 1990, o Brasil passou a utilizar um esquema terapêutico para os pacientes com resistência multidroga, sendo o único país a oferecer toda a possibilidade de tratamento de forma gratuita. Também para os pacientes acometidos de co-infecção tuberculose-Aids, estabeleceu-se um sistema normativo que permite assistência adequada com oferta grátis e universal dos medicamentos.

A partir de 2001, as ações de controle da tuberculose estão sendo desenvolvidas em seis eixos de atuação: mobilização técnica, política e social em torno de metas de controle da doença; descentralização das ações e mudança no modelo de atenção, com a reorganização dos serviços; melhoria da vigilância epidemiológica e do sistema de informação; ampliação e qualificação da rede de laboratórios; garantia de assistência farmacêutica, com distribuição descentralizada e acompanhamento de estoques; e capacitação de recursos humanos. 
O fortalecimento das ações em nível da atenção básica, sobretudo com a incorporação de atividades anti-tuberculose ao Programa de Saúde da Famîlia, possibilita importante ampliação da cobertura do programa nacional de controle. Busca-se também a melhoria qualitativa das ações, mediante incentivo ao tratamento supervisionado de pacientes, segundo a estratégia Dors (Directly Observed Treatment, Short-Course) promovida pela Opas/OMS.

\section{Doenças transmissíveis emergentes e reemergentes}

Um quarto grupo de doenças expressa o fenômeno mundial de emergência e reemergência de doenças transmissíveis. São consideradas 'emergentes' as doenças que surgiram ou foram identificadas nas duas últimas décadas, e ainda aquelas que, antes de ocorrência rara e restrita, passaram a se constituir como problemas de saúde pública. Como 'reemergentes', consideram-se as doenças que voltaram a representar problema de saúde pública após terem sido controladas no passado.

Desde o início da década de 1980, algumas doenças infecciosas passaram a ser registradas ou foram reintroduzidas no país, destacando-se a Aids (1980), o dengue (1982), a cólera (1991) e a hantavirose (1993), sendo que destas, somente a cólera apresentou redução significativa na última década. A rápida disseminação da Aids no país, por sua vez, condicionou o aumento da ocorrência de outras doenças infecciosas, particularmente a tuberculose.

A partir da deteç̧ão da Aids no Brasil, observou-se seu crescimento acelerado até 1997, ano em que foram registrados 23.545 casos novos, com um coeficiente de incidência de 14,8 casos/100.000 hab. A partir de então, diminuiu a velocidade de crescimento da epidemia, com uma redução da sua incidência. No período de 1995 a 1999, observou-se redução de $50 \%$ na taxa de letalidade em relação aos primeiros anos do 
início da epidemia, quando esta taxa era de $100 \%$. A disponibilidade de novas drogas tem propiciado o aumento na sobrevida para os portadores da infecção pelo vírus do HIV.

A cólera experimentou seu pico epidêmico em 1993, com 60.340 casos. Apesar do ambiente favorável para a disseminação e persistência dessa doença, pela insatisfatória condição sanitária de parte da população, os esforços do sistema de saúde conseguiram reduzir drasticamente sua incidência.

Em 1998 e 1999, a seca que ocorreu na região Nordeste, onde se instalou uma severa crise de abastecimento de água, inclusive nas capitais, favoreceu a possibilidade de recrudescimento da cólera, o que exigiu uma intensificação das ações de prevenção e de vigilância epidemiológica nessa região. A doença passou a se manifestar sob a forma de surtos, principalmente nas pequenas localidades do Nordeste com maior dificuldade de acesso à água tratada e à deficiência de esgotamento sanitário. Eventualmente, outras formas de transmissão podem ser associadas com surtos, como o ocorrido no porto de Paranaguá (PR), relacionado com o consumo de mariscos.

No ano de 2000, a cólera apresentou redução importante, tanto no número de casos, quanto na área geográfica em que se manifestava. Foram registrados 734 casos, quase todos ocorridos em apenas dois estados da região Nordeste (Pernambuco e Alagoas); já no ano de 2001, houve em todo o país apenas sete casos da doença, também concentrados nesta região. Os dados dos últimos dois anos asseguram a situação de controle da cólera e, mantida essa tendência, a doença passará a integrar o grupo das enfermidades transmissiveis com tendência declinante ou mesmo a categoria de doenças eliminadas.

0 dengue tem sido objeto de uma das maiores campanhas de saúde pública realizadas no país. 0 mosquito transmissor da doença, o $\mathrm{A}$. aegypti, que havia sido erradicado de vários países do continente americano nas décadas de 1950-60, retornou na década seguinte, em decorrência de falhas na vigilância epidemiológica e de mudanças sociais e ambientais propiciadas pela urbanização acelerada dessa época. 
Atualmente, o mosquito transmissor é encontrado numa larga faixa do continente americano, que se estende desde o Uruguai até o sul dos Estados Unidos, com registro de surtos importantes da doença em vários países, como Venezuela, Cuba, Brasil, El Salvador e, recentemente, Paraguai.

Nos últimos três anos, vem sendo registrado um aumento no número de casos, alcançando cerca de 700 mil em 2002. Dentre outros fatores que pressionam a incidência do dengue, destaca-se a introdução recente de um novo sorotipo, o DEN 3 , parà 0 qual a susceptibilidade é praticamente universal. A circulação seqüencial de mais de um sorotipo propiciou um aumento na incidência de febre hemorrágica do dengue, com consequiente incremento na mortalidade pela doença.

Os primeiros casos de hantaviroses no Brasil foram detectados em 1993, em São Paulo, passando a doença a ser registrada, com maior freqüência, nas regiões Sul, Sudeste e Centro-Oeste. Com a implantação da vigilância epidemiológica de hantaviroses e o desenvolvimento de capacidade laboratorial para o diagnóstico, aumentou a detecção de casos e foi possível conhecer melhor a situação epidemiológica da doença, inclusive quanto à circulação dos hantavírus em roedores silvestres. Também foram tomadas medidas adequadas de prevenção e controle, como a divulgação de recomendações para tratamento dos casos, de forma a reduzir a letalidade.

O Brasil integra a rede de vigilância epidemiológica de doenças emergentes e reemergentes nos países amazônicos. Essa iniciativa foi tomada em 1998 e conta com apoio técnico e financeiro da 0pas em parceria com os CDC dos Estados Unidos da América. Uma das metodologias utilizadas é a de vigilância sindrômica de maior sensibilidade para a detecção de casos, propiciando informação oportuna e variada sobre a ocorrência dessas doenças na região.

\section{Síndrome de Imunodeficiência Adquirida}

No final do século $\mathrm{XX}$, a Aids destacou-se como uma das doenças emergentes de maior magnitude e impacto causadas às populações das di- 
ferentes regiões do mundo, assumindo, em cada região, uma característica própria, estreitamente ligada ao comportamento humano individual, coletivo e social. De 1980, quando o primeiro caso foi registrado no Brasil, até setembro de 2001, 222.356 casos já foram notificados, tendo sido estimado, para 0 ano de 2000, uma prevalência de cerca de 600 mil indivíduos de 15 a 49 anos de idade infectados pelo vírus da imunodeficiência adquirida (HIV).

O número de casos notificados aumentou rapidamente, entre 1987 e 1992, para então apresentar uma redução na velocidade de crescimento, observando-se, em 1998, uma taxa de incidência de 20,3 casos por 100 mil habitantes, sendo mais elevada entre os homens.

A epidemia de Aids no Brasil desenvolveu-se em, pelo menos, três fases. A primeira fase compreendeu o início dos anos 1980, caracterizandose pela concentração dos casos nas metrópoles brasileiras mais industrializadas, localizadas no Centro-Sul do país, e tendo como categoria de exposição principal as relações homo ou bissexuais masculinas (Gráfico 14).

Gráfico 14 - Distribuição dos casos de Aids no sexo masculino, segundo principais categorias de exposição, por ano de diagnóstico. Brasil - 1980-1998

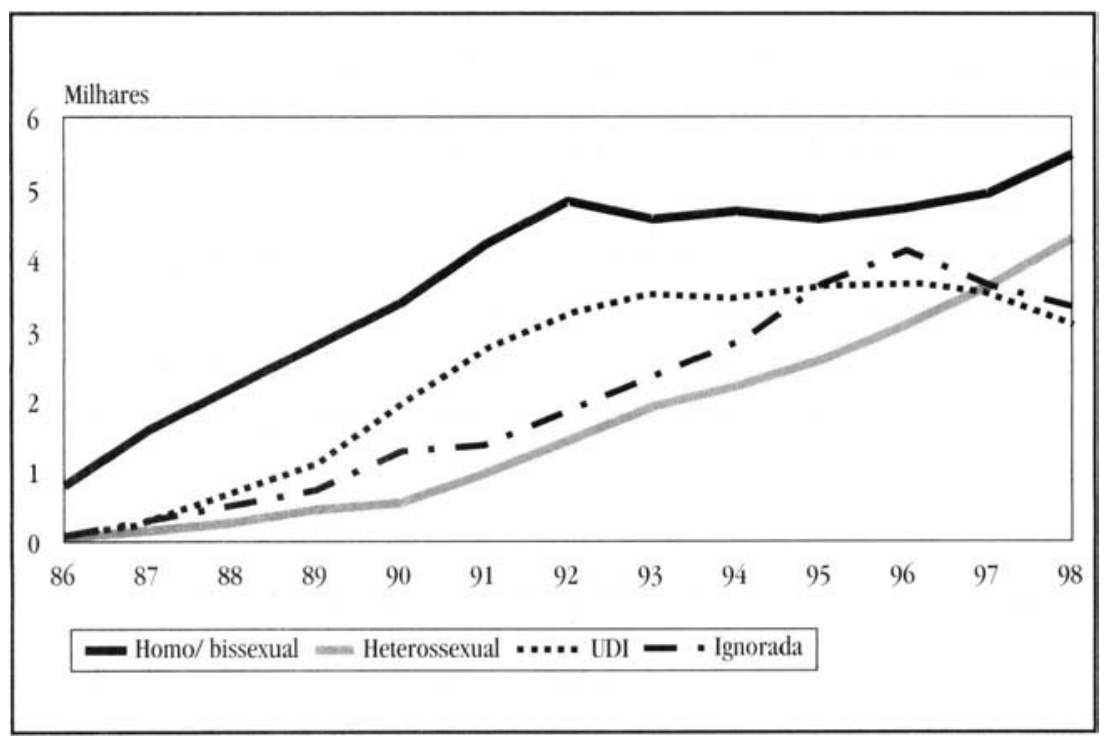


A segunda fase abrangeu o período do final dos anos 80 e início $\mathrm{da}$ década de 1990, sendo caracterizada pelo aumento dos casos em virtude da transmissão por uso de drogas injetáveis, pelo início do aumento dos casos via transmissão heterossexual, bem como pela expansão da epidemia para todos os estados brasileiros, embora ainda atingindo, basicamente, as regiões metropolitanas e cidades de porte médio (200-500 mil habitantes), principalmente das regiões Sul e Centro-Oeste.

A terceira fase da epidemia tem sido caracterizada pela estabilização da transmissão homo/bissexual e pelo aumento da transmissão heterossexual, com uma grande expansão para os municípios de menor porte, especialmente na região Sul, além de atingir as regiões Norte e Nordeste com maior intensidade. Como resultado da expansão da epidemia na população heterossexual, observou-se um aumento importante dos casos entre as mulheres, tendo como conseqüência direta 0 aumento dos casos em crianças infectadas via transmissão vertical. Após ações de prevenção efetivadas a partir dos anos finais da década de 1990 , observou-se a desaceleração no crescimento dessa forma de transmissão, embora menos evidente em algumas regiões, como no caso da região Sul, onde a epidemia apresentou grande crescimento.

Pode-se observar que a epidemia de aids reflete a grandeza e a diversidade socio-geográfica do país e sua marcante heterogeneidade regional, fazendo da epidemia brasileira uma soma de subepidemias regionais. Embora de abrangência nacional, com importante concentração nos grandes centros urbanos do Centro-Sul do país, a epidemia disseminou-se de forma mais lenta na década de 1990, principalmente na região Sudeste e nos municípios de maior porte populacional. Aumentou, assim, a proporção de municípios com menos de 200 mil habitantes que registraram casos de Aids, principalmente os localizados no sentido litoral-interior do país, seguindo as rotas do sistema rodoviário, ferroviário ou aéreo (Figura 3). 
Figura 3 - Distribuição espacial dos municípios com pelo menos um caso de Aids notificado por período. Brasil - 1980-1998

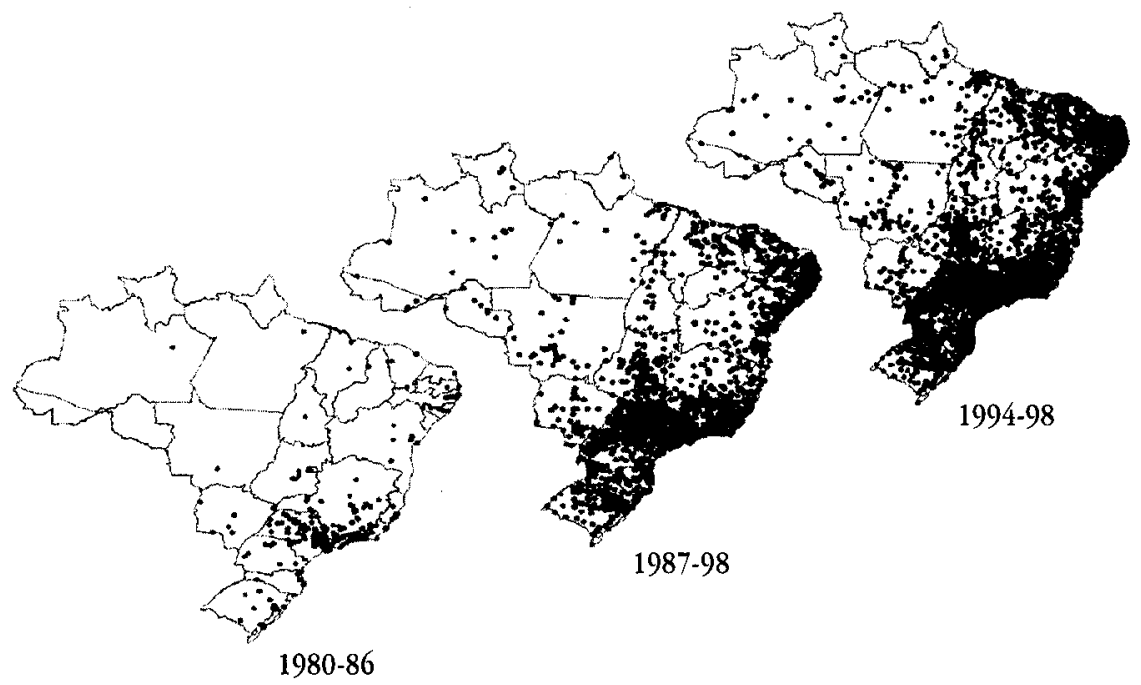

De forma contrastante, observou-se uma tendência de maior aceleração no ritmo de crescimento da epidemia na região Sul, que se disseminou em vários segmentos populacionais, indicando que a epidemia ainda não estava contida nesta região no final do século, principalmente devido ao uso de drogas injetáveis. As regiões Nordeste e Norte, embora com taxas de incidência baixas, apresentavam, no final da década de 1990, taxas de crescimento elevadas.

Como foi visto, a desaceleração da epidemia não se deu de forma universal, sendo seletiva do ponto de vista dos segmentos populacionais afetados. Evidências de um processo de empobrecimento da epidemia, no sentido de aumento da incidência de casos na população de menor nível socioeconômico, foram descritas, principalmente devido à transmissão heterossexual e ao uso de drogas injetáveis, e, entre as mulheres, com progressiva mudança no gradiente social, expresso na maior velocidade de disseminação nos segmentos populacionais de nível socioeconômico mais baixo. 
De 1980 a 1999, 117.011 óbitos tiveram como causa básica a Aids e foram registrados pelo Sistema de Informação sobre Mortalidade, ou seja, a epidemia teve grande impacto na mortalidade. Já na metade da década de 1990, a Aids passou a figurar como uma das principais causas de óbito em indivíduos de 20 a 49 anos de idade, para então apresentar redução importante nas taxas de mortalidade, principalmente entre os homens e na região Sudeste.

Com as medidas de prevenção e assistência implementadas mais efetivamente a partir da segunda metade da década de 1990, a sobrevida dos casos adultos aumentou de 5 meses, naqueles registrados na década de 1980, para 58 meses, naqueles registrados em 1996. Entre as crianças com até 12 anos de idade, a sobrevida aumentou para 46 meses, em média, nos casos registrados entre 1995 e 1996, sobressaindo o peso da terapia antiretroviral, que elevou a sobrevida para mais de 102 meses.

A Aids entra no século XXI como uma epidemia ainda a ser controlada. Entretanto, são inegáveis os avanços e o papel desempenhado pelo Ministério da Saúde nas ações de vigilância, prevenção e assistência aos indivíduos com Aids. A sistematização das ações de vigilância do HIV e da Aids, com aprimoramento da definição de casos e seus registros; a intensificação das ações de prevenção, juntamente com a participação da sociedade civil organizada, e a luta pelos direitos humanos e a política de aquisição e distribuição de medicamentos de última geração a todos os pacientes, implantada a partir de 1996, juntamente com a normalização das ações de assistência, certamente contribuíram para as reduções observadas nas taxas de crescimento da incidência e nas taxas de mortalidade, estimando-se que, com essas ações, cerca de 34 mil óbitos e 33 mil casos de Aids foram evitados no período de 1994 a 1999.

\section{Dengue}

Ainda que a primeira epidemia laboratorialmente documentada de dengue no Brasil tenha ocorrido em 1982, na cidade de Boa Vista, 
estado de Roraima, sabe-se hoje de registros da doença no país desde o ano de 1846, no Rio de Janeiro, quando foi chamada 'polca'. São esparsos os relatos da doença, que adquire outros nomes, em momentos e locais diversos. Essa memória se havia perdido, quando o país foi reinfestado por $A$. aegypti em 1975/76, a partir da cidade de Salvador. 0 risco de que a transmissão da doença viesse a se restabelecer no Brasil foi subestimado. Contribuiu para isso o caráter benigno da doença na sua forma clássica e o quase completo desconhecimento de que poderiam ocorrer formas graves, com manifestações hemorrágicas severas. A febre hemorrágica do dengue (FHD) fora descrita apenas em 1953, em Manila, nas Filipinas. Ademais, até que viesse a ser conhecida em Ilhas do Pacífico e nas Américas, era considerada como problema restrito a países da Ásia, em especial do sudeste asiático.

Nas décadas de 1960-70, havia transmissão na Venezuela e no Caribe. Naquela primeira epidemia em Boa Vista, foram conhecidos aproximadamente 12.000 casos e isolados os sorotipos 1 e 4 . Depois disso, pelo relativo isolamento geográfico da área onde foi de início introduzido e pela dispersão ainda limitada do vetor, houve um período de quatro anos até que novos episódios de dengue fossem conhecidos.

No ano de 1986, surtos importantes ocorreram nos estados de Alagoas, Ceará e na cidade do Rio de Janeiro, causados pelo sorotipo 1 do vírus do dengue. Essas epidemias se esgotaram no ano seguinte, mas novas ondas vieram a ocorrer, com certa periodicidade. Isso se deveu à introdução do sorotipo 1 em novas áreas infestadas (Bahia, Pernambuco e São Paulo) ou do sorotipo 2, a partir de 1991, naquelas mesmas grandes cidades onde havia já circulado o sorotipo 1, como o Rio de Janeiro e Fortaleza.

Começavam, assim, a ser criadas as condições necessárias para a ocorrência da febre hemorrágica do dengue. No Rio de Janeiro, entre 1991 e 1992, foram identificados 462 casos de FHD, com 8 óbitos. A transcendência da doença assumiu outra dimensão, e esta passou a ser 
reconhecida como um dos principais problemas de saúde pública no país, com a agravante de sua baixa vulnerabilidade às medidas de controle existentes.

$\mathrm{Na}$ prevenção primária, pode-se atuar somente sobre o vetor, cuja extraordinária capacidade de proliferação e difusão é facilitada pelas condições urbanas atuais, muito diferentes das do passado, quando o $\mathrm{A}$. aegypti chegou a ser erradicado, na década de 1950. Entre as grandes mudanças havidas, destacam-se: a concentração populacional no meio urbano $(81,2 \%$ na média nacional), com um arranjo habitacional caótico nos grandes centros, habitações precárias e sem um suprimento regular de água potável; maior mobilidade populacional, com a possibilidade de deslocamento a longas distâncias e por meios de locomoção mais rápidos, e a grande oferta de criadouros potenciais, pela destinação inadequada de embalagens e recipientes descartáveis de toda natureza. Essas condições facilitam a dispersão e a persistência do vetor, como também limitam as operações de controle, especialmente difíceis pela complexidade da malha urbana nas grandes cidades.

As dificuldades de erradicar um mosquito domiciliado, que se multiplica em quaisquer recipientes capazes de armazenar água - especialmente os encontrados nos depósitos de lixo urbano (garrafas, latas, pneus etc.) ou no interior dos domicílios (pratos de vasos de plantas) - , têm exigido um esforço substancial do setor saúde, com um gasto estimado em mais de R\$ 1 milhão por dia. Esse trabalho próprio do setor saúde necessita ser articulado com outras políticas públicas, como a limpeza urbana, além de uma maior conscientização e mobilização social.

Nos últimos três anos, a incidência do dengue ascendeu a 428.117 casos, em 2001. Ademais, um novo fator tende a pressionar esse aumento, representado pela introdução recente de outro sorotipo, o DEN 3, para 0 qual a susceptibilidade é praticamente universal. 
Em 1996, o Ministério da Saúde propôs um Programa de Erradicação do $A$. aegypti (PEAa). No entanto, o método de erradicação do mosquito veio a se mostrar tecnicamente inviável, devido à complexidade epidemiológica da doença. A despeito de o programa ter promovido um significativo aumento dos recursos disponíveis, as ações de combate ao vetor estavam ainda centradas quase que exclusivamente no uso de inseticidas em atividades de campo.

Em junho de 2001, o Ministério da Saúde e a Opas realizaram, em conjunto, um Seminário Internacional para avaliar as diversas experiên cias em andamento. Daí resultou a adoção de uma nova estratégia de atuação, não mais voltada à erradicação do vetor, mas ao controle da doença, mediante iniciativas que integravam os seus distintos componentes. 0 Plano de Intensificação das Ações de Controle do Dengue (PuACD), então instituído no país, selecionou 657 municípios como áreas prioritárias para a intensificação de medidas em andamento e para a adoção de iniciativas de maior eficácia.

Entre as principais medidas que vêm sendo implementadas por ação conjunta da Fundação Nacional de Saúde (FunasA) e das secretarias estaduais e municipais de saúde, destacam-se: a intensificação das ações de combate ao vetor, prioritariamente nos municípios com maior participação na geração dos casos; o fortalecimento das ações de vigilância epidemiológica e entomológica para ampliar a oportunidade da resposta ao risco de surtos; a integração das ações de vigilância e de educação sanitária, com os programas de saúde da família e de agentes comunitários de saúde; e uma forte campanha de mobilização social e de informação pública para garantir a efetiva participação da população. Tem sido também priorizada a melhoria na capacidade de detecção de casos de dengue hemorrágico, com vistas a reduzir a letalidade a níveis inferiores a $1 \%$. 
Gráfico 15 - Casos notificados de dengue por grandes regiōes. Brasil - 1977-2000.

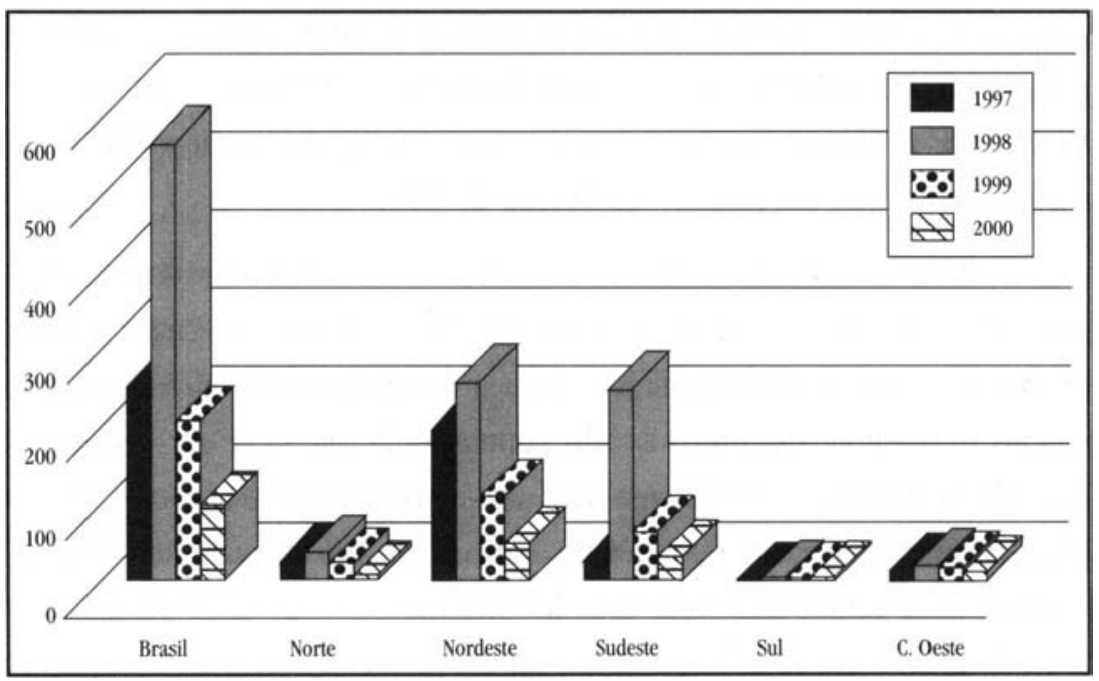

\section{Doenças crônico-degenerativas: novas prioridades}

\section{Doenças cardiovasculares}

Apesar de ser a primeira causa de morte no Brasil, são escassas as informações de base populacional sobre a ocorrência das doenças cardiovasculares. Os estudos sobre a prevalência da hipertensão arterial são em pequeno número e possuem abrangência limitada, enquanto apenas cinco pesquisas abordam outras morbidades cardiovasculares. Três delas foram efetuadas em Salvador (Bahia), uma em Joinville (Santa Catarina) e outra em Araraquara (São Paulo).

Os resultados encontrados em Salvador mostram elevada incidência de doenças cerebrovasculares, com taxas estimadas em 168/100.000 adultos $\geq 15$ anos, no início da década de 1980 , e em cerca de $180 / 100.000$ adultos $\geq 20$ anos, em 1994. Para o infarto agudo do miocárdio, a taxa foi de 99/100.000 adultos $\geq 25$ anos. Os fatores de risco, em Salvador, mostraram- 
se mais potentes para as doenças cerebrovasculares, sendo que a hipertensão estava presente em $80 \%$ dos casos ( $92 \%$ em estudo recente, ainda não publicado). Em Joinville, a incidência da doença cerebrovascular também foi elevada (156/100.000 habitantes) e, em Araraquara, a prevalência de angina era de 6\%, em meados da década de 1980.

Dois estudos sobre fatores de risco cardiovascular no Brasil foram realizados, há mais de uma década, em São Paulo e em Porto Alegre. Outros foram específicos para obesidade e para o tabagismo e incluíram todas as regiões brasileiras. Um outro estudo populacional que deve ser considerado, pela importância na epidemiologia das doenças cardiovasculares, é o da prevalência de diabetes e intolerância à glicose no Brasil, realizado em nove capitais, distribuídas nas cinco grandes regiões.

Muitos dos fatores de risco também têm sua prevalência conhecida a partir de investigações específicas sobre hipertensão e obesidade. 0 estudo mais abrangente sobre dislipidemias no país foi realizado em Salvador, no ano de 1995, mediante análise clínico-epidemiológica de amostra representativa da demanda laboratorial não hospitalar, procedente de todos os tipos de prestadores de assistência. A elevada prevalência de valores acima dos esperados, para colesterol, lipoproteínas e triglicerídios, mostrou-se semelhante às descritas em estudos mais limitados.

São conhecidas as dificuldades metodológicas, em estudos nacionais, para a correta categorização das variáveis 'classe social' e 'raça', o que tem levado à maior utilização do 'nível de escolaridade' como indicador da condição social. Embora o elevado grau de miscigenação da população brasileira torne polêmica a classificação racial, têm-se constatado que, à exceção do estudo em Araraquara, os negros sempre apresentam maior prevalência de hipertensão arterial.

Pode-se afirmar que, em conjunto, os fatores de risco para doenças cardiovasculares são tão freqüentes e importantes no Brasil quanto em países desenvolvidos. Cabe ressaltar, porém, que os estudos sobre hipertensão 
realizados no país apresentam grandes diferenças metodológicas entre si, inclusive quanto aos critérios adotados.

Outra importante fonte de informações é representada por dados secundários sobre morbidade hospitalar e ambulatorial a partir de registros contínuos de produção do SUS, que apresentam ampla cobertura nacional e são de grande importância para o planejamento do setor. Uma análise parcial dos dados brutos para todo o Brasil retrata a situação de gravidade das doenças cardiovasculares da população atendida na rede hospitalar própria ou contratada pelo SUS.

Do total de hospitalizações por doenças do aparelho circulatório, realizadas no período de 1982 a 1997 , analisou-se a frequiência relativa de hospitalizações e de letalidade hospitalar por doença hipertensiva (DH), insuficiência cardíaca (IC), doença arterial coronária, (DAC) e doença cerebrovascular (DCbV). Os resultados mostram: leve descenso na tendência das internações por doença arterial coronária, decréscimo da doença hipertensiva, discreto aumento da doença cerebrovascular e grande elevação da insuficiência cardíaca. As tendências mais marcantes das curvas são observadas a partir de 1992 (Gráfico 16).

Gráfico 16 - Tendência das hospitalizações no SUS para DH, DAC, IC e DCbV. Brasil - 1984-1997

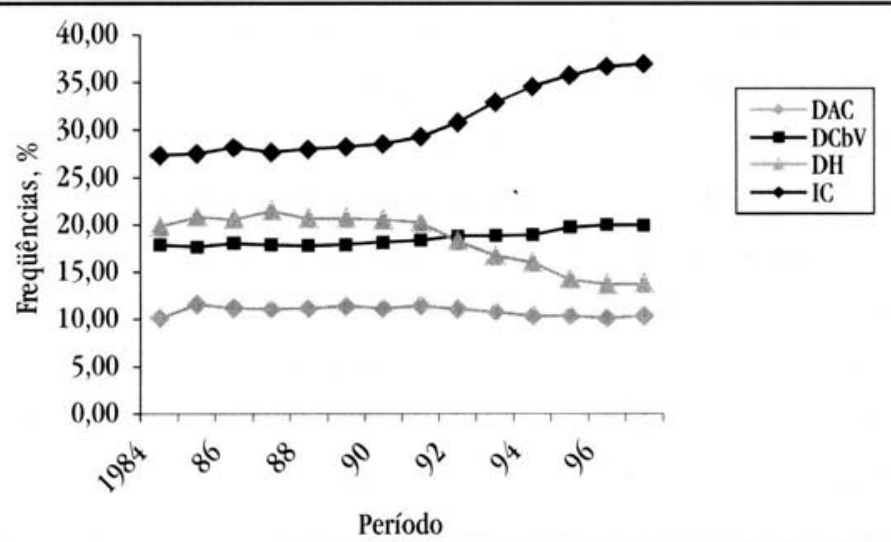


A inversão nas tendências da doença hipertensiva e da insuficiência cardíaca poderia estar relacionada à qualidade assistencial, mas também ao crescente envelhecimento da população, com consequiente e esperado aumento das hospitalizações por insuficiência cardíaca. Quanto à letalidade hospitalar por doenças cardiovasculares, calculada a partir dos registros de atendimento no SUS, acredita-se que esteja subestimada, pois as taxas são bem inferiores às obtidas nos próprios hospitais por busca rigorosa, como também às informadas em países que dispõem de estatísticas de saúde e de condições assistenciais mais favoráveis.

Nos estudos de morbidade, não se identifica com clareza predominância de sexo. Para a hipertensão, a maioria dos estudos faz referências a taxas de prevalência mais altas em homens, enquanto para as doenças cerebrovasculares não há diferenciação significativa. No único estudo sobre infarto, a incidência foi maior para homens até os 65 anos e, a partir dessa idade, as taxas equivalem-se às das mulheres. Todas as doenças cardiovasculares têm suas frequiências elevadas com o envelhecimento. A letalidade é sempre maior para mulheres, tanto na doença arterial coronária quanto nas cerebrovasculares.

No que se refere à mortalidade, os três estudos nacionais sobre tendência da $\mathrm{DCbV}$, medida por coeficientes, mostraram declínio para o município de São Paulo (1971-1980) e discreto declínio em ambos os sexos para Porto Alegre (1976-1986) e para mulheres de Recife, Belém e Goiânia. A mortalidade proporcional, no entanto, apresenta tendência crescente, de 1950 a 1994, nas regiões Norte, Nordeste e Centro-Oeste e tênue declínio no Sul e no Sudeste. Destaca-se a alta frequiência de óbitos por DCbV em idade economicamente ativa (20-59 anos), cujo declínio entre 1982 e 1995 foi muito pequeno, de $30 \%$ para $26 \%$ do total de mortes por DCbV. Esses valores são quase 2,5 vezes maiores que os observados nos Estados Unidos há cerca de uma década (12\%). A tendência para doenças isquêmicas do coração no município de São Paulo também é declinante. 
Dados recentes sobre mortalidade proporcional mostram que, entre 1980 e 1995, houve acentuada redução da doença hipertensiva na região Norte e incremento na Nordeste, enquanto as DAC e as DCbV apresentaram discreto declínio na região Sudeste.

Ao se considerarem esses dados, cabe ressaltar que pequenas variações percentuais dos valores encontrados correspondem a números muito elevados de ocorrências, que expressam quantitativamente 0 ônus social das doenças cardiovasculares no Brasil. No período analisado, o número anual aumentou de 999.000 para 1.550 .000 hospitalizações, devendo-se agregar, a esse custo diferencial, os acréscimos vinculados à introdução de novas tecnologias, mais dispendiosas. Outro tipo de impacto se expressa pela perda anual de centenas de milhares de anos de vida economicamente ativa, por doença cardiovascular precoce, o que poderia ser reduzido com a oferta de assistência médica de melhor qualidade. Além das mortes, parte dos sobreviventes, incapacitados ou inválidos, aposenta-se ainda em idade potencialmente produtiva.

Toda doença cardiovascular determina elevados custos sociais quando a prática médica restringe-se à medicina clínica. Uma das variáveis consideradas nos cálculos desses custos é o tempo de permanência hospitalar, considerado muito elevado em um estudo que comparou os anos de 1985 , 1990, 1995 e 1997. Destaca-se a média de permanência por DCbV na região Sudeste (cerca de 13 dias), que influencia a média nacional.

Desde 0 início de 2001, o Ministério da Saúde vem implementando o Plano de Reorganização da Atenção ao Diabete Melito e à Hipertensão Arterial, destinado a orientar a prestação de serviços aos portadores dessas doenças. Esse plano, desenvolvido pela OpAs, está estruturado em quatro etapas: capacitação do pessoal da rede básica de serviços de saúde, identificação de casos suspeitos, confirmação diagnóstica e registro e acompanhamento de pacientes. Os resultados alcançados no Brasil motivaram o reconhecimento público da OMS, como um dos programas de saúde pública mais eficientes $\mathrm{e}$ melhor organizados, nas Américas, para enfrentar essas doenças. 


\section{Neoplasias}

Como analisado anteriormente, as doenças infecciosas e parasitárias, a partir dos anos 1960, deixaram de ser a principal causa de morte, sendo substituídas pelas doenças do aparelho circulatório e pelas neoplasias. Essa progressiva ascensão da mortalidade por doenças crônico-degenerativas tem, como principal fator, o envelhecimento da população, resultante do intenso processo de urbanização e das ações de promoção e recuperação da saúde. Tais condições propiciam a exposição contínua a fatores ambientais e mudanças de comportamento, responsáveis pela carcinogênese (Gráfico 17).

Gráfico 17 - Taxa de mortalidade por câncer, ajustada por idade pela população mundial. Brasil - 1979-1999*

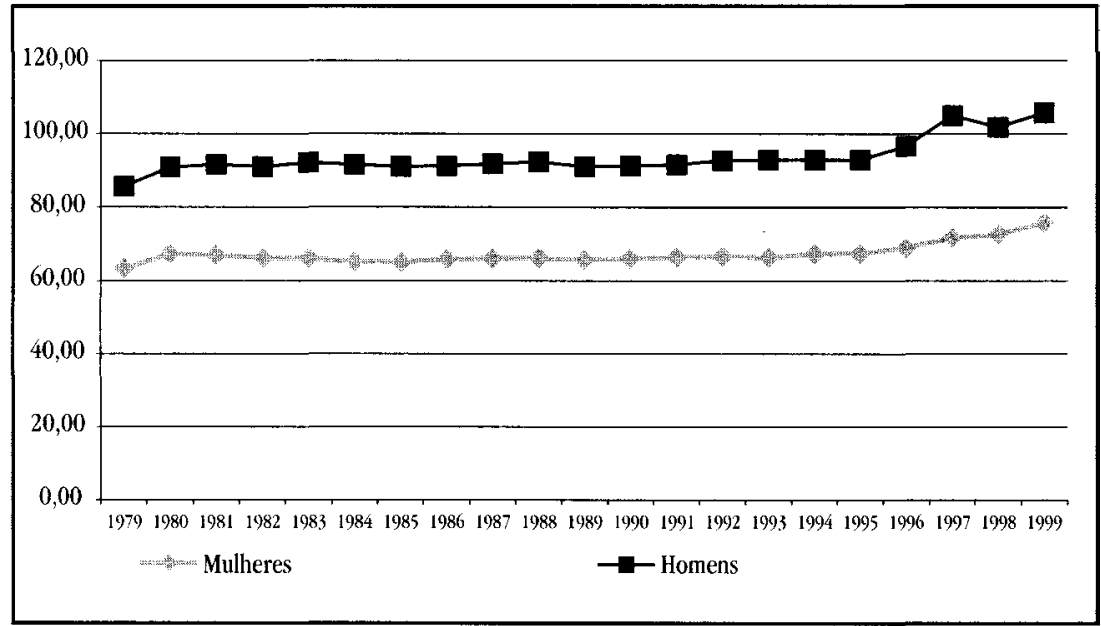

* População padrão mundial, modificada por Doll et al.(1966).

Fonte: MS. Funasa. Cenepi: SIM, Inca. Conprev.

A análise mostra que, tanto em homens quanto em mulheres, ocorreu no Brasil, ao longo das duas últimas décadas, uma tendência crescente de óbitos por câncer. Neste período, os tumores de maior mortalidade localizaram-se, entre homens, no pulmão, estômago, esôfago, próstata e cólon e reto, e, entre mulheres, na mama, estômago, colo do útero, cólon e reto e pulmão. 
0 câncer de pulmão contribuiu, em 1999, com o maior número de óbitos por câncer na população brasileira, representando $12,3 \%$ do total. As taxas de mortalidade por câncer do pulmão continuam aumentando acentuadamente em ambos os sexos, sendo mais marcante nas mulheres. 0 aumento crescente deste tipo de câncer é consequiência da epidemia tabagística que vem progressivamente atingindo mais as mulheres brasileiras, a partir da década de 1960 . De todos os casos de câncer do pulmão, 90\% são atribuíveis ao tabagismo.

0 câncer de estômago representou cerca de $9,4 \%$ da mortalidade por câncer em 1999. Entres os homens, alcança o dobro das taxas verificadas para as mulheres ao longo do período de 1979 a 1999. As taxas de mortalidade por este tipo de câncer apresentam um comportamento decrescente no Brasil, compativel com o ocorrido em vários outros países, em relação tanto à mortalidade quanto à incidência. Tal declínio reflete, ao menos em parte, o maior consumo de frutas e vegetais frescos e o concomitante declínio de consumo de sal e de alimentos defumados e enlatados nas décadas que se seguiram à última guerra mundial.

0 câncer de cólon e reto aparece como a quinta maior causa de morte por câncer no Brasil em 1999 (6,3\%), com aumento consistente das taxas ao longo das últimas duas décadas. Apresenta comportamento similar ao observado em escala mundial, em que ocupa a terceira posição em homens e a quarta em mulheres. Embora o câncer do cólon e reto tenha fatores de risco de natureza hereditária (por exemplo, polipose familiar), a variabilidade internacional sugere fortemente a existência de causas ambientais. Além da possibilidade de prevenção primária, por meio do consumo de dieta rica em frutas, vegetais e fibras, enquanto pobre em gorduras animais, a mortalidade por câncer do cólon e reto pode ser controlada por meio de estratégias de deteç̧ão e tratamento precoces.

0 câncer de esôfago vem apresentando, no Brasil, discreto aumento ao longo dos últimos vinte anos, constituindo-se a sexta maior 
causa de morte por neoplasia maligna, no Brasil, em 1999. As taxas de mortalidade no sexo masculino são quatro vezes maiores que em mulheres. No período de 1979 a 1998, o aumento percentual da taxa em homens foi de $26 \%$, enquanto em mulheres foi de $12 \%$. Os principais fatores de risco associados a esta neoplasia são o consumo de álcool, o tabagismo e a dieta pobre em fibras.

0 câncer da próstata é a segunda maior causa de mortalidade por neoplasias malignas entre homens brasileiros, representando $11,7 \%$ desse total, em 1999. No mundo, ocupa o quinto lugar entre as malignas de maior mortalidade. Analogamente ao câncer de mama em mulheres, o de próstata foi o que mais cresceu no sexo masculino, no período de 1979 a 1999; a taxa de mortalidade aumentou cerca de $140 \%$, ao passar de 3,73 óbitos por 100 mil homens, em 1979, para 8,93, em 1999. À semelhança do que ocorre em países desenvolvidos, a magnitude das taxas de mortalidade no Brasil reflete, pelo menos parcialmente, o envelhecimento da população. Dietas ricas em gordura animal podem aumentar as taxas de androgênios e estrogênios, relacionadas com o aumento dos tumores da próstata, ao contrário da gordura vegetal e dos frutos do mar.

0 câncer da mama feminina é a primeira causa de óbito por câncer em mulheres no Brasil, correspondendo a $15,43 \%$ do total de 52.516 mortes por câncer registrados em 1999. As taxas de mortalidade vêm aumentando significativamente nas últimas duas décadas, de forma mais acentuada a partir de 1990. Este aumento é compatível com a crescente urbanização da população brasileira, que condiciona maior exposição a fatores de risco, entre os quais se destacam: o histórico familiar, especialmente se o câncer ocorreu na mãe ou em irmã, se foi bilateral e se desenvolveu antes da menopausa; a exposição à radiação ionizante, antes dos 35 anos; a menopausa tardia, além dos 50 anos, em média; e a primeira gravidez após os 30 anos de idade. Entre os fatores alimentares, cabe destacar a ingestão regular de álcool, mesmo que em quantidade moderada, e a obesidade. 
A mortalidade por câncer do colo do útero ocupou no Brasil, em 1999, a terceira posição, com 7,39\% das mortes por câncer em mulheres. Este tipo de câncer, ao longo dos últimos 21 anos, vem apresentando incidência crescente, principalmente a partir de 1985 , em contraposição à tendência declinante que se observa em países mais desenvolvidos. As taxas de mortalidade passaram de 3,44 para 4,67 óbitos por 100 mil mulheres, entre 1979 e 1999 , o que representa uma variação de $35,7 \%$ no período. Deve-se considerar a disponibilidade de ações de controle eficazes para esse tipo de câncer, mas que têm impacto na mortalidade pelo menos 10 anos após serem instituídas regularmente. Vários são os fatores sociais, ambientais e os hábitos de vida identificados com o risco do câncer do colo do útero, destacando-se a atividade sexual antes do 18 anos de idade, a pluralidade de parceiros sexuais, o vício de fumar, a higiene precária e o uso prolongado de contraceptivos orais.

\section{Diabete melito}

0 diabete melito (diabetes mellitus) é um importante e crescente problema de saúde para todos os países, independentemente de seu grau de desenvolvimento. Nas últimas décadas, têm-se documentado um aumento na incidência e na prevalência de suas duas principais formas clínicas, ou seja, o diabete tipo 1 (não insulino-dependente) e 0 diabete tipo 2 (insulinodependente). No caso do diabete tipo 2, sua prevalência está aumentando de forma exponencial, adquirindo características epidêmicas em vários países, particularmente os em desenvolvimento. Esse aumento, por sua vez, representa potencialmente maiores encargos para os sistemas de saúde, pela associação do diabete com taxas de hospitalização e incapacitação, incidência de doenças cardiovasculares, cegueira, insuficiência renal e amputações não traumáticas de membros inferiores.

O Estudo Multicêntrico sobre a Prevalência do Diabete no Brasil, realizado em nove capitais estaduais, no biênio 1987-1988, mostrou que a 
prevalência do diabete e da tolerância, diminuída à glicose, na população urbana entre 30 e 69 anos de idade, foi de 7,6\% e 7,8\%, respectivamente. Ou seja, $15,4 \%$ da população dessa faixa etária necessitaria de algum cuidado em saúde. As maiores taxas foram observadas nas cidades de São Paulo $(0,7 \%)$ e Porto Alegre (8,9\%). Não foram detectadas diferenças na prevalência do diabete quanto ao sexo, cor ou nível socioeconômico. Os indivíduos com excesso de peso ou história familiar de diabete apresentaram taxas duas vezes maiores. $0 \mathrm{~s}$ casos de diabete previamente diagnosticados corresponderam a $54 \%$ dos casos identificados. Os resultados desse estudo tornaram possível o reconhecimento da importância do diabete como problema de saúde pública no Brasil e vêm orientando as ações de saúde no controle da doença.

No ano de 2001, o Ministério da Saúde realizou uma campanha de detecção de diabete, de abrangência nacional, focalizando a população com idade igual ou superior a 40 anos, sem diagnóstico prévio de diabete, baseada na realização de glicemia capilar. Mesmo considerando as limitações desse tipo de levantamento, foram realizados pouco mais de 20 milhões de exames, com detecção de 3,3 milhões de indivíduos com suspeita de diabete, ou seja, $16 \%$ da população participante. 0 s casos suspeitos estão sendo objeto de outra investigação, também coordenada pelo Ministério da Saúde, para verificar se o diagnóstico foi confirmado e se a rede pública de saúde está dando resposta a esta necessidade identificada.

De modo geral, os dados de mortalidade obtidos mediante declarações de óbito subestimam a importância da mortalidade por diabete. Frequientemente, a doença não figura na declaração, pois a codificação utilizada seleciona como causa de óbito as complicações do diabete, preferencialmente as doenças cardiovasculares. A importância do diabete como causa de óbito pode ser evidenciada pela mortalidade proporcional, ou seja, o quanto essa causa contribui para o total de 6́bitos. Os dados apresentados no Gráfico 18 ressaltam a importância crescente que a mortalidade por diabete vem apresentando em relação ao total de óbitos, em capitais brasileiras, para a população com 20 ou mais anos de idade, no período de 1950 a 1999. 
Gráfico 18 - Evolução da mortalidade proporcional por diabete na população com 20 e mais anos de idade. Brasil e capitais - 1950-1999

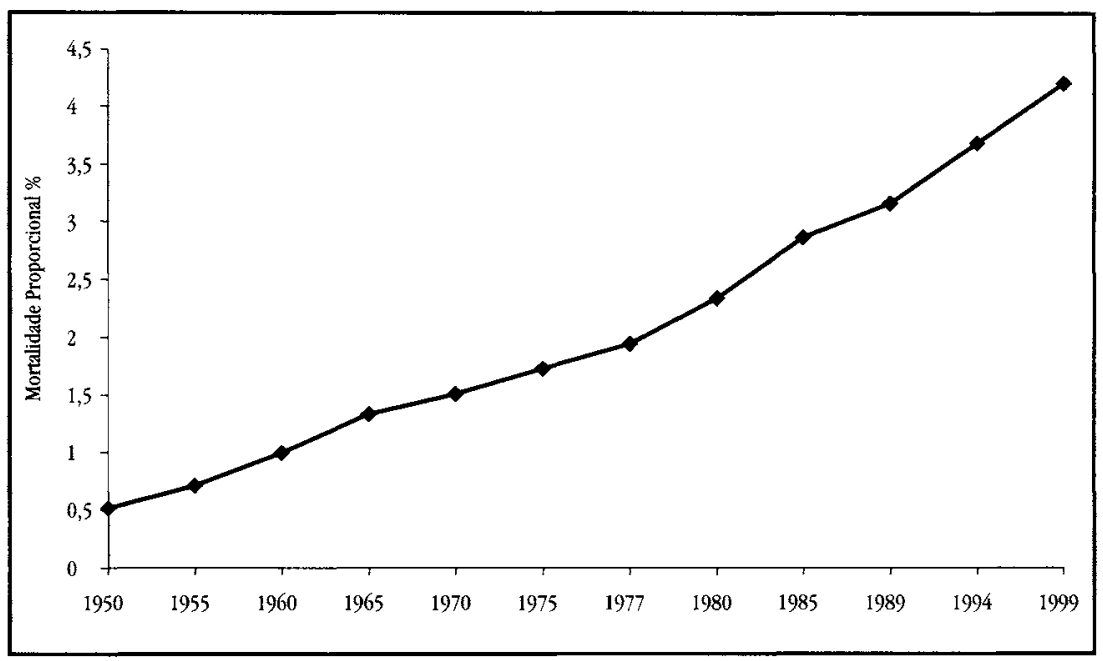

Em que pesem as limitações atuais da informação disponível no Brasil, os dados de prevalência e de mortalidade por diabete evidenciam que se trata de um problema crescente e que está assumindo proporções preocupantes, com importantes repercussões para o sistema de saúde do país. Além disso, observa-se que vários de seus fatores de risco, em particular a obesidade e o sedentarismo, estão também se tornando mais prevalentes, contribuindo para o agravamento do problema.

Até o presente, são raros os estudos brasileiros que têm procurado avaliar medidas de prevenção primária em relação ao diabete tipo 2. Isto contrasta com o observado em vários países desenvolvidos, onde há consciência da impossibilidade do sistema de saúde suportar a crescente carga representada pelo diabete, e da necessidade de desenvolver e implementar medidas de prevenção, particularmente as de atenção básica. Evidências recentes, entre as quais as derivadas de estudo realizado na Finlândia, mostram que a incidência de novos casos de diabete tipo 2 pode ser reduzida pela metade, com medidas de prevenção primária dirigidas à população de maior risco. 


\section{Acidentes e violência}

Estudos variados vêm evidenciando que, a partir da década de 1980 , aumentou no Brasil a incidência de morte por acidentes e violência, sobretudo entre os grupos mais vulneráveis, os jovens e os mais pobres, em geral do sexo masculino. Esse grupo de causas tem produzido alterações importantes no perfil demográfico e de mortalidade brasileiro, chegando a comprometer os ganhos em expectativa de vida da população, que vêm sendo alcançados pela redução da mortalidade infantil.

Em 1999, as causas externas fizeram 116.934 vítimas fatais, o equivalente a $14,7 \%$ do total dos óbitos no país. Nesses últimos vinte anos, elas tiveram um incremento de $16 \%$, ao passar de 59 óbitos por 100 mil habitantes, em 1980, para 69 por 100 mil, em 1999 (Gráfico 19).

Gráfico 19 - Taxa de mortalidade por causas externas, acidentes de transporte e homicídios. Brasil - 1980-1999*

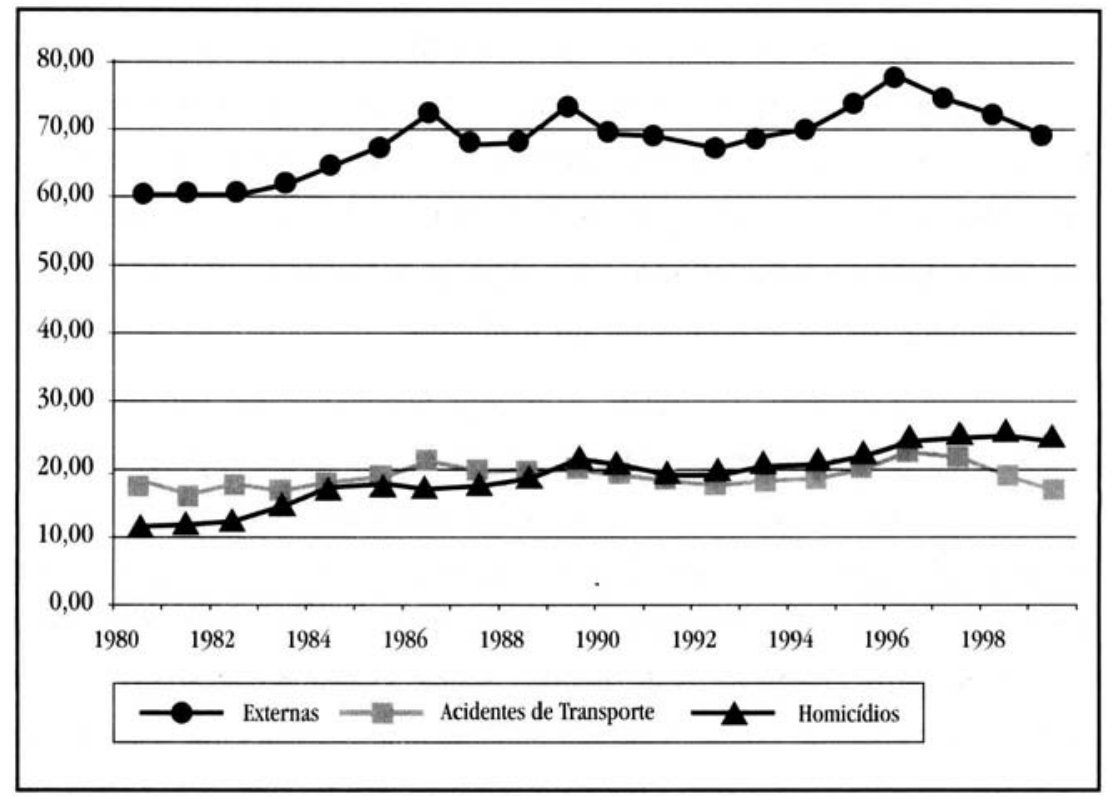

* Taxas por $100.000 \mathrm{hab}$. 
Os tipos de violência que mais afetam a população brasileira são os homicídios e os acidentes de transporte, que respondem, em conjunto, por mais de $60 \%$ das mortes por causas externas. Entre 1980 a 1999, os óbitos por homicídio tiveram acréscimo de $115 \%$ e superaram, a partir de 1990 , as mortes causadas por acidentes de transporte, que incrementaram apenas $6 \%$ no mesmo período. As vítimas de homicídios passaram de 13.601 pessoas, no início da década de 1980 (taxa de $12 / 100$ mil), para 42.921 pessoas, em 1999 (taxa de 25/100 mil). Esse aumento está relacionado a questões como a proliferação de armas de fogo, o crescimento do narcotráfico e o acirramento das desigualdades sociais. As armas de fogo são responsáveis pela maioria das mortes no grupo de adultos jovens e de adolescentes acima de 15 anos, principais vítimas de conflitos associados a disputas pelo tráfico de drogas e aos confrontos com a polícia.

Do total de óbitos por causas externas informados em 1999, as principais vítimas foram homens $(84,1 \%)$, principalmente adultos jovens com idade entre 20 e 39 anos (43,8\%). A sobremortalidade masculina foi de 6:1, ou seja, para cada óbito feminino, ocorreram seis masculinos. Quando se analisa esse mesmo fenômeno por faixas etárias, constata-se que, nos grupos de 20 a 29 anos e 30 a 39 anos, os riscos são bem maiores, de 10 e de 8 vezes, respectivamente. Em qualquer faixa etária, porém, os homens sempre apresentam maior risco de morrer que as mulheres.

Na Tabela 9, apresenta-se a distribuição das mortes por causas externas específicas, segundo as grandes regiões brasileiras. Pode-se perceber a importância relativa dos subgrupos de acidentes de transporte e de homicídios, com predomínio destes em todas as regiões, exceto a Sul, onde prevalecem as mortes por acidentes de transporte $(37,7 \%)$ e se destaca 0 elevado percentual de suicídios $(13,1 \%)$. Nessa análise comparativa, porém, há que considerar a melhor qualidade dos dados na região Sul, onde apenas $6,0 \%$ dos eventos estão registrados como 'lesões ignoradas se acidentais ou intencionalmente infligidas'. Na média nacional, essa proporção é de $8,6 \%$. 
Tabela 9 - Mortalidade proporcional por causas externas específicas

\begin{tabular}{|c|c|c|c|c|c|c|c|c|c|c|}
\hline Causas & \multicolumn{2}{|c|}{ Norte } & \multicolumn{2}{|c|}{ Nordeste } & \multicolumn{2}{|c|}{ Sudeste } & \multicolumn{2}{|c|}{ Sul } & \multicolumn{2}{|c|}{$\begin{array}{c}\text { Centro- } \\
\text { Oeste }\end{array}$} \\
\hline & $\mathbf{N}$ & $\%$ & $\mathbf{N}$ & $\%$ & $\mathbf{N}$ & $\%$ & $\mathbf{N}$ & $\%$ & $\mathbf{N}$ & $\%$ \\
\hline Acidentes de transporte & 1681 & 27,5 & 6001 & 25,1 & 13194 & 22,7 & 5974 & 37,7 & 2767 & 31,7 \\
\hline Quedas acidentais & 182 & 3,0 & 766 & 3,2 & 2645 & 4,6 & 747 & 4,7 & 298 & 3,4 \\
\hline Submersão, sufocação & 559 & 9,1 & 1738 & 7,3 & 3034 & 5,2 & 1289 & 8,1 & 447 & 3,4 \\
\hline Outros acidentes & 646 & 10,6 & 3455 & 14,4 & 5087 & 8,8 & 847 & 5,3 & 557 & 6,4 \\
\hline Suicídio & 289 & 4,7 & 1091 & 4,6 & 2449 & 4,2 & 2071 & 13,1 & 605 & 6,9 \\
\hline Homicídios & 2087 & 34,2 & 8041 & 33,6 & 25082 & 43,2 & 3553 & 22,4 & 2827 & 32,4 \\
\hline Lesões ign. acid./intenc. & 492 & 8,1 & 1924 & 8,0 & 5456 & 9,4 & 949 & 6,0 & 956 & 11,0 \\
\hline Demais causas & 174 & 2,8 & 910 & 3,8 & 1116 & 1,9 & 428 & 2,7 & 265 & 3,0 \\
\hline TOTAL & 6110 & 100,0 & 23926 & 100,0 & 58063 & 100,0 & 15858 & 100,0 & 8722 & 100,0 \\
\hline
\end{tabular}

As informações disponíveis sobre morbidade hospitalar indicam que, em 1999, 7,6\% das hospitalizações realizadas em estabelecimentos próprios ou conveniados ao SUS foram ocasionadas por lesões e envenenamentos (excluídas as internações vinculadas à gravidez, parto e puerpério, que corresponderam a $25,7 \%$ do total de 11.950 .595 internações). A pequena participação dessas causas, no total das internações, é provavelmente devida à subestimação, pois o Sistema de Informações Hospitalares (SIH) não computa os casos atendidos nas emergências e pronto-socorros, bem como as internações ocorridas em unidades de saúde não conveniadas ao SUS.

Na composição das 678.787 hospitalizações por esse grupo de causas, em 1999, destacam-se as quedas acidentais $(42,1 \%)$ e os acidentes de transporte $(18,6 \%)$. Como esperado, as quedas motivaram mais de $55 \%$ das internações entre os idosos com 60 e mais de 60 anos. Por sua vez, os acidentes de transporte foram motivo de $23,4 \%$ das internações de adultos jovens. Chama atenção o elevado percentual de internações provocadas pelos acidentes por fogo e chamas em crianças $(9,1 \%)$. No conjunto das internações por lesões e envenenamentos, destacam-se os traumatismos, 
com proporçẽes superiores a $80 \%$, em todas as regiões do país, sendo mais frequientes as fraturas $(52,7 \%)$ e as lesões traumáticas $(25 \%)$ provenientes, sobretudo, de quedas e acidentes de transporte.

A maioria das internações por lesões e envenenamentos corresponde à população masculina (70,5\%, em 1999), representando 2,4 vezes 0 número de mulheres hospitalizadas pelas mesmas causas. Do óbitos ocorridos nesse universo, $84,1 \%$ eram homens, e a razão entre os sexos aumentou para 6:1. A população de 20 a 29 anos foi responsável por $20,2 \%$ dos casos, com $28,4 \%$ dos óbitos informados.

No caso dos acidentes de transporte, os resultados mostram a existência de risco diferenciado segundo as faixas etárias. Os atropelamentos são mais comuns entre os idosos e as colisões são mais freqüentes entre adultos jovens. A evolução das taxas de mortalidade por acidentes de transporte, por regiões, mostra que apenas na região Norte houve decréscimo das taxas, embora a redução não seja estatisticamente significativa. Nas demais regiões houve aumento, sendo que apenas o Nordeste apresentou crescimento significativo ( $\mathrm{p}<0,05$ ), ao passar de 10 óbitos por 100 mil habitantes, no triênio 1979/81, para 14 óbitos por 100 mil, no triênio 1997/99. A forma mais freqüente de acidente é por colisão de veículos $(62 \%$ dos casos). A proporção de atropelamentos, cujas vítimas são os pedestres, cresce em função da população do município. Entre os atropelamentos, o risco de morrer aumenta com a idade, atingindo seu ponto máximo na faixa etária de 60 anos e mais (15,35 óbitos por $100 \mathrm{mil})$.

\section{Desigualdade e complexidade dos padrões epidemiológicos brasileiros}

Os indicadores de morbi-mortalidade da população brasileira, quando comparados com os de países de nível socioeconômico semelhante, mostram aspectos inusitados que refletem as desigualdades internas exis- 
tentes no país. Tem sido bem documentada a situação paradoxal de o Brasil apresentar indicadores econômicos em níveis incompatíveis com os dos indicadores sociais, inclusive de saúde, como a taxa de mortalidade infantil e a expectativa de vida a nascer. Ainda que se observe uma tendência de melhoria de alguns indicadores de saúde no Brasil, a reduzida velocidade desse processo propicia a persistência das desigualdades ou até mesmo a sua ampliação.

No contexio nacional, a existência de desigualdades inter-regionais pode ser melhor apreendida pelas diferenças entre os indicadores de mortalidade. Enquanto nas regióes Sul e Sudeste, as doenças infecciosas e parasitárias (DIP) já representavam a quinta causa de óbito em 1980 (excluídas as declarações com sinais e sintomas mal definidos), na região Nordeste, este grupo constituía a segunda causa, e somente em anos recentes passou à mesma posição que ocupa nas demais regiões. As doenças cardiovasculares, por sua vez, representavam a primeira causa de óbito para todas as regiões, já em 1980. Em 1999, porém, a taxa de mortalidade padronizada para este grupo de causas, na região Sudeste, era superior em $83,2 \%$ e $77,0 \%$, respectivamente, às taxas registradas nas regiões Nordeste e Norte.

As desigualdades entre as regiões podem ser também visualizadas nos indicadores relacionados à composição da morbidade. Assim, para os mesmos grupos de causas de morbidade hospitalar que foram analisados para a mortalidade, verifica-se que as doenças cardiovasculares representaram, em 2001, a segunda causa de internações nas regiões Sul e Sudeste, em seguida às doenças respiratórias. Nessas duas regiões, no mesmo ano, as DIP corresponderam à terceira e à quarta causa de internações, respectivamente. Na região Nordeste, contudo, as DIP ainda representaram a segunda causa de internações em 2001, enquanto as doenças cardiovasculares constituíram a terceira causa.

A análise histórica dos indicadores globais de saúde também evidencia 0 quadro de desigualdades entre as regiões do país. Na década de 1930, a taxa de mortalidade infantil (TMI) situava-se em 153 óbitos por 
1.000 nascidos vivos, na região Sudeste; em 127, na região Sul; e em 168, na região Nordeste. Portanto, a região Nordeste apresentava taxa $10 \%$ superior à da Sudeste e 32\% superior à da região Sul. Para o ano de 1999, a TMI no Nordeste era $154 \%$ maior que a da região Sudeste, e $205 \%$ maior que a taxa da região Sul. Apesar de ter sido observada melhoria absoluta em todas as regiões, o agravamento das diferenças relativas mostra que as soluções em busca do cumprimento das potencialidades biológicas está ocorrendo em diferentes intensidades, provocando a ampliação das desigualdades. Devese destacar que, na última década, ocorreu uma maior redução relativa na taxa de mortalidade infantil para a região Nordeste, que apresentava o valor mais elevado. Quanto à expectativa de vida ao nascer, verifica-se tendência de maiores ganhos durante o período 1991-1999, nos estados que apresentavam os menores valores no início do período.

Outros indicadores de morbidade, de base não hospitalar, também revelam as desigualdades inter-regionais. Assim, as maiores taxas de incidência ou prevalência para doenças, como cólera (até 0 ano de 2001, quando foram registrados os últimos casos), esquistossomose, doença de Chagas e leishmanioses, têm sido registradas nas regiões Norte, Nordeste e Centro-Oeste.

Há evidências mundiais de que a estratificação da população por níveis socioeconômicos define também estratos diferenciais nos níveis de saúde. Países desenvolvidos ou em desenvolvimento, com diferentes patamares nos níveis de saúde das suas populações e com diferentes padrões epidemiológicos, assemelham-se no tocante à existência destes gradientes. A frequiência de qualquer doença, com raras exceções, aumenta com a redução do nível social e econômico dos grupos sociais. É consistente o fato de que, entre países com níveis econômicos similares, aqueles com maiores níveis de desigualdade social apresentam níveis mais baixos de saúde. Por exemplo, dentre os países desenvolvidos, os Estados Unidos, apesar de ser o mais rico, é o que apresenta maiores desigualdades sociais, gerando diferenciais nos indicadores de saúde entre distintos grupos populacionais. 
Organismos internacionais (Banco Mundial, Organização Mundial da Saúde) vêm reconhecendo que, sem reduções significativas nas iniquiidades sociais, será impossível haver melhoras mais substanciais no quadro global de saúde da população, pois melhorias modestas no padrão das desigualdades têm fortes efeitos nos níveis de saúde.

No Brasil, esta questão assume grande importância e ganha nuances especiais. Por exemplo, em 1999, 50\% dos óbitos infantis concentraram-se nos $30 \%$ dos nascidos vivos que residem nos estados com as maiores taxas de pobreza, bem como a TMI estimada em 1996 para os 20\% dos brasileiros mais pobres foi três vezes maior que a estimada para os $20 \%$ de maior poder aquisitivo. A concentração da riqueza e dos bens gera imensas distâncias também entre as suas regiões ou entre seus espaços intra-urbanos. No interior das cidades brasileiras, são também observados diferenciais nas taxas de mortalidade infantil, bem como na de mortalidade pela maioria das doenças, entre as zonas mais pobres e as zonas mais ricas das cidades. Iniquiidades relacionadas aos gêneros e aos grupos étnicos agravam tal situação.

Foi visto antes que, entre as principais causas de óbito e internamentos na população brasileira, estão as doenças crônico-degenerativas, os acidentes e as diversas formas de violência. Entretanto, já se observam tendências recentes de redução da mortalidade por algumas causas específicas de doenças cardiovasculares, em níveis suficientes para reduzir as taxas totais para esse grupo. Entre as doenças infecciosas, cuja mortalidade encontra-se em franco declínio, observa-se também significativa redução na morbidade por um conjunto importante de enfermidades.

Em outra direção, vê-se 0 reaparecimento, nas duas décadas passadas, de doenças que pareciam superadas, como a cólera e o dengue, que expõem a fragilidade das estruturas ambientais urbanas no país e ampliam a carga já elevada de doenças da população. A isso se soma o surgimento de novas doenças, ou de novas formas de manifestação de doenças já conhecidas, gerado pelo aumento na severidade de novas cepas patogênicas e pela 
ampliação da resistência aos antimicrobianos. De outra parte, essas novas situações coexistem com a persistência de agravos, como a desnutrição, e de doenças endêmicas, como a tuberculose, que impõem manter estruturas de atenção dispendiosas, consumindo recursos escassos que poderiam ser canalizados para a solução de problemas de saúde de maior magnitude e com menores possibilidades de prevenção a curto prazo, como as doenças crônicas não-transmissíveis.

Um quadro bem paradigmático dessa superposição de padrões ocorre com relação aos problemas nutricionais, visto que reduções na prevalência da desnutrição proteico-calórica estão sendo acompanhadas pelo crescimento da obesidade e da anemia. Deve-se destacar também que, em geral, o tratamento das 'doenças da modernidade' requer mais recursos tecnológicos e, como conseqüência, implica maiores custos para o sistema de saúde. A violência, por exemplo, ao lado das mortes e incapacidades que causa em nossa população produtiva, implica pesada sobrecarga para os sistemas de saúde e previdenciário.

A falta de solução para alguns problemas estruturais e básicos, a manutenção de condições e modo de vida inadequados e a insuficiência nos mecanismos que regulam os danos ao meio ambiente ocasionam a superposição dos riscos aos quais está exposta a população. Assim, se, de um lado, mantêm-se os problemas urbanos caracterizados por marcantes deficiências em áreas como saneamento ambiental, habitação e transporte, de outro, têm-se o surgimento da poluição ambiental de origem química (industrial, inseticidas etc.), os riscos ocupacionais, o aumento dos fatores estressores gerados pela 'modernização' das relações sociais, as mudanças comportamentais, o desemprego estrutural e crescente e a ampliação das desigualdades intra-urbanas. Ademais, o fato de o envelhecimento da população ocorrer em condições em que se associam múltiplos riscos amplifica as chances de ocorrência de várias doenças, aumentando a carga mórbida e reduzindo a qualidade de vida deste grupo populacional. 
Existem cada vez mais relatos sobre os efeitos deletérios, sobre a saúde, de fatores que se dão no plano internacional. Assim, os efeitos da denominada globalização que está relacionada com questões tão aparentemente diversas, como o aumento das desigualdades entre as nações, a intensificação do comércio internacional, em especial o comércio de produtos alimentícios, o narcotráfico e o contrabando de armas e cigarros, ou o aumento da temperatura global ocasionada pela crescente poluição atmosférica, são exemplos de 'novos riscos globais' com efeito na deterioração das condições de saúde. Esta superposição de fatores ambientais e sociais 'velhos' e 'novos' é o que torna possível a permanência de algumas doenças tradicionais e emergência ou 're-emergência' de outras tantas, em paralelo ao aumento das doenças crônicas e das violências. Tomemos o exemplo do desemprego, que, além da privação a que sujeita os indivíduos e suas famílias, com efeitos no estado nutricional de adultos e crianças e no risco de exposição às doenças infecciosas, provoca aumento na ocorrência das doenças psiquiátricas e cardiovasculares.

Tendo em vista a impossibilidade de atuação, em curto prazo, sobre alguns riscos gerados pelos processos globais, faz-se urgente a superação de algumas categorias de risco tradicionalmente vinculadas à ocorrência de doenças e cuja superação pode ser alcançada, por decisões políticas mais limitadas. Por exemplo, a completa resolução das desigualdades no acesso aos serviços de saúde, no déficit de suprimento de água e do esgotamento sanitário, em muitos centros urbanos. Já é amplamente conhecido o efeito positivo da melhoria das condições de saneamento, não somente na diminuição de várias doenças infecciosas responsáveis por importantes demandas no sistema de saúde, como também na proteção para o ressurgimento de outros problemas. Não por acaso, o ressurgimento da cólera, na década de 1990 , poupou locais com alto padrão de saneamento. 


\section{Implicações para as políticas de saúde}

A superposição de problemas de saúde implica a manutenção, ao longo dos anos, de uma carga de morbidade e de mortalidade com magnitude semelhante; e a redução dessa carga, dentro dos limites biológicos estabelecidos, representa um desafio para a definição de políticas de saúde.

Os benefícios para a população, conseqüentes à redução da mortalidade por doenças infecciosas e da morbidade por algumas delas, como também da mortalidade por doenças cardiovasculares, não somente devem ser mantidos, como necessitam ser ampliados para outras causas de adoecimento e morte. Esses resultados positivos indicam que existe tecnologia suficiente para melhorar os padrões de morbidade e mortalidade e também que, em contexto socioeconômico e ambiental favorável, os efeitos dessa melhora são mais intensos e duradouros. Tal constatação supera a proposição inicial, no contexto da aplicação do termo 'transição epidemiológica' para explicação das grandes mudanças nos padrões epidemiológicos nos países desenvolvidos e nos demais países da América Latina.

Entretanto, não se deve reforçar a ilusão, disseminada subliminarmente, de que é possível vivermos em um mundo sem doenças - incluindo as transmissíveis. Este não constitui o cenário das presentes gerações, ao menos com o conhecimento atual que se dispõe sobre as potencialidades biológicas e as tecnologias disponíveis.

As modificações internas na composição das causas de morbidade e de mortalidade têm gerado melhorias significativas dos indicadores de saúde do país. 0 processo de envelhecimento da população também representa um avanço na plena utilização do potencial biológico. Entretanto, na medida em que a ocorrência de doenças tem-se caracterizado por superposição de suas causas e riscos, um efeito que pode ser observado é a manutenção, ou mesmo o incremento, nas causas de incapacidade. Nesse aspecto, o desafio para as políticas de saúde, integradas às demais políticas sociais, é agregar a qualidade de vida ao aumento da longevidade humana. 
A melhoria de indicadores de saúde não é alcançada de forma homogênea em todos os grupos populacionais, o que contribui para a manutenção da carga persistente de morbidade, inclusive por causas redutíveis, que permanecem em determinados patamares. Ainda que as políticas de saúde tenham a possibilidade de ampliar benefícios para grupos populacionais antes excluídos, é imprescindível que as ações estejam articuladas com outras políticas públicas, voltadas para o enfrentamento dos complexos fatores determinantes das doenças. Sem essa articulação, a desigualdade nos padrões epidemiológicos atuais tende a ser mantida.

\section{Bibliografia}

ACHUTTI, A. \& MEDEIROS, A. M. B. Hipertensão arterial no Rio Grande do Sul. Boletim da Saúde, 12: 6-54, 1985.

AGUDELO, S. F. El Quinto: no matar. Bogotá: Cooperación Salud y Desarrollo, 1999.

ALTER, M. et al. Incidence ratios of stroke: a worldwide review. Neuroepidemiology, 5: 148-158, 1986.

ARAÚJO, F. A. A. \& STAFM, A. Análise epidemiológica da ocorrência de raiva humana no Brasil, no período de 1992 a 1997, 1999. Monografia, Brasília.

BARBOSA, M. T. S. \& STRUCHINER, C. J. The estimated magnitude of Aids in Brazil: a delay correction applied to cases with lost dates. Cadernos de Saúde Pública, 18 (1): 279-285, 2002.

BARBOSA, R. B.; BARCELÓ, A. \& MACHADO, C. A. Campanha nacional de deteç̧ão de casos suspeitos de diabetes mellitus no Brasil: relatório preliminar. Revista Panamericana de Salud Pública, 10: 324-327, 2001.

BARBOSA, V. Estado atual do problema da poliomielite no município de São Paulo. Revista de Saúde Pública, 2 (1): 68-80, 1968.

BARBOSA, V. Aspectos de importância para a vigilância epidemiológica da poliomielite na cidade de São Paulo. Revista de Saúde Pública, 14: 557-568, 1980.

BARCELLOS, C. \& BASTOS, F. I. Redes sociais e difusão da Aids no Brasil. Boletín de la oficina Sanitaria Panamericana, 121: 11-24, 1996.

BARCELLOS, T. M. M. (Coord.). A Política Social Brasileira 1930-64: evolução institucional no Brasil e no Rio Grande do Sul. Porto Alegre: Fundação de Economia e Estatística, 1983.

BARRETO, M. L. \& CARMO, E. H. Tendências recentes das doenças crônicas no Brasil. In: LESSA, I. (0rg.) o Adulto Brasileiro e as Doenças da Modernidade: epidemiologia das doenças crônicas não transmissiveis. São Paulo/Rio de Janeiro: Hucitec/Abrasco, 1998.

BARRETO, M. L. et al. Saúde da população brasileira: mudanças, superposição de padrões e desigualdades. In: FLEURY, S. (Org.) Saúde e Democracia: a luta do Cebes. São Paulo: Lemos Editora, 1997. 
BAYER, G. F. et al. População brasileira no século XX: alguns dados. Dados (Radis/Fiocruz), 2: 1-8, 1982.

BEAGLEHOLE, R. International trends in coronary heart disease mortality, morbidity, and risk factors. Epidemiol. Rev., 12: 1-15, 1990.

BELOTTO, A. J. A raiva no Brasil em 1984: aspectos operacionais e epidemiológicos. Rev. Fund. Sesp, 30 (2): 167-182, 1985.

BENCHIMOL, J. L. Febre Amarela: a doença e a vacina, uma bistória inacabada. Rio de Janeiro: Editora Fiocruz, 2001.

BEMFAM. Pesquisa Nacional sobre Saúde Materno-Infantil e Planejamento Familiar (PNSMIF) - Brasil, 1986. Rio de Janeiro, 1987.

BENFAM. IBGE. Pesquisa Nacional sobre Demografia e Saúde (PNDS), mar. 1997.

BLACK, R. J. et al. Cancer incidence and mortality in the European Union: cancer registry data and estimates of national incidence for 1990. European Journal of Cancer, 33 (7): 1075-1107, 1997.

BOYLE, P. Global burden of cancer. The Lancet, 349 (suppl. II): 23-26, 1997.

BRASIL. Ministério da Saúde. Departamento Nacional de Endemias Rurais. Endemias rurais: métodos de trabalho adotados pelo DNERu. Rio de Janeiro: MS/DNERu, 1968.

BRASIL. Ministério da Saúde. Plano nacional de controle da poliomielite. Rio de Janeiro, 1971. (Mimeo.)

BRASIL. Ministério da Saúde. Ação de controle da poliomielite. Brasília, 1981. (Folheto, 25 p.).

BRASIL. Ministério do Planejamento e Orçamento. Instituto Brasileiro de Geografia e Estatística. Diretoria de Pesquisa. Departamento de População e Indicadores Sociais. População residente 1980-1996: Brasil, unidades da federação e municípios. Rio de Janeiro: DESEM, 1990. (Disponível em CD-ROM).

BRASIL. Ministério da Saúde. Fundação Nacional de Saúde. Coordenação de Controle de Doenças Transmitidas por Vetores. Controle da malária: diretrizes técnicas. Brasília: FNS, 1995.

BRASIL. Ministério da Saúde. Sistema de informação sobre mortalidade, 1999. (Disponível em: http:/ /www.datasus.gov.br).

BRASIL. Ministério da Saúde. Secretaria Nacional de Assistência à Saúde. Instituto Nacional do Câncer. Coordenação Nacional de Controle do Tabagismo, Prevenção e Vigilância do Câncer. Falando sobre câncer de mama. Rio de Janeiro: Inca/MS, 1999.

BRASIL. Ministério da Saúde. Mortalidade por Aids no Brasil: atualização até 1997. Boletim Epidemiológico Aids, ano XII, n.1, dez. 98 - fev. 99, 1999.

BRASIL. Ministério da Saúde. Fundação Nacional da Saúde. Centro Nacional de Epidemiologia. Manual de vigilância para a erradicação do sarampo e controle da rubéola. Brasilia, 2001.

BRASLL. Ministério da Saúde. Boletim Epidemiológico Aids, ano XV, n.1, jul. 01- set. 01, 2002.

BRASIL. Ministério da Saúde. Sistema Único de Saúde. Sistema de informação sobre mortalidade 1979-1997: dados de declaração de óbito. Brasília: SUS. (Disponível em CD-ROM).

BRASS, W. et al. Estimating mortality from deficient registration data. In: Metbods for estimating fertility and mortality from limited and defective data. Chapel Hill: University of North Carolina at Chapel Hill/International Program of Laboratories for Population Statistics, 1975.

BRENT, D. A. \& KOLKO, D. J. Suicídio e comportamento em crianças e adolescentes. In: Infância e Adolescência. Porto Alegre: Artes Médicas, 1992. 
BRITO, A. M.; CASTILHO, E. A. \& SZWARCWALD, C. L. Aids e infecção pelo HIV no Brasil: uma epidemia multifacetada. Revista da Sociedade Brasileira de Medicina Tropical, 34 (2): 207-217, 2000.

BRITO BASTOS, N. C. et al. Programa antipoliomielítico en el Brasil: estudio de niveles de imunidad. Boletín de la Oficina Sanitaria Panamericana, LXXV, jul.-dic. 1973.

BRITSH MEDICAL JOURNAL (BMJ). Managing chronic disease. Editorials. British Medical Journal, 318: 10090-10091, 1999.

BROOKE, E. M. El suicidio y los intentos de suicidio. Genebra: Organização Mundial de Saúde, 1986. (Documento n. 58).

BUSSAB, W. O. Análise de Variância e de Regressão. São Paulo: Atual, 1986.

BUSVINE, J. R. \& BARNES, S. Observations on mortality among insects exposed to dry insecticidal films. Bulletin of Entomological Research, 38: 80-81, 1947.

CABRAL, N. L. et al. Epidemiologia dos acidentes cerebrovasculares em Joinville, Brasil. Arq. Neuropsiquiatr., 55: 357-363, 1997.

CAMARG0, M. C. C. et al. Predictors related to the occurrence of a measles epidemic in the city of São Paulo in 1997. Revista Panamericana de Salud Pública, 7: 359-65, 2000.

CANO, W. Questão regional e urbanização no desenvolvimento econômico brasileiro pós-1930. In: ENCONTRO NACIONAL DE ESTUDOS POPULACIONAIS, 6, 1988, Olinda. Anais... Belo Horizonte: Abep, 1988. p. 67-99. v.2

CARRIERI, M. L. Raiva Humana: estudo documental a partir de dados do Instituto Pasteur de São Paulo, 1970-1997, 1998. Tese de Doutorado, São Paulo.

CASSORLA, R. M. S. Autodestruição humana. Ciência E Saúde Coletiva, 10 (supl. 1): 61-73, 1994.

CENTER FOR DISEASES CONTROL AND PREVENTION 2002 (CDC). Prevention fact sheet. Suicide Prevention and Control. Disponível em: http://www.cdc.gov/ncipc/factsheets/suifacts.htm. (Arquivo capturado em 20 de junho de 2002).

CHAGAS, C. Nova espécie mórbida do homem produzida por um trypanozoma (Schizotripanum cruzi). Brazil-méd., 23 (16): 161, 1909. (Nota prévia).

CHEQUER, P. J. N. Epidemiologia e serviços de saúde. In: Qualidade de Vida: compromisso bistórico da epidemiologia. Belo Horizonte: Coopmed/Abrasco, 1994.

CHESNAIS, J. C. A violência no Brasil: causas e recomendações. Ciência $\varepsilon$ Saúde Coletiva, 4 (1): 53 69, 1999.

CLAVES. ENSP. FIOCRUZ. Relatório perfil de mortalidade por causas externas no Brasil: uma análise temporal das décadas de 80 e 90, 2001. (Mimeo.)

COALE, A. J. \& TRUSSELL, J. Model fertility schedules: variations in the age structure of childbearing in human populations. Population Index, 40 (2): 185-257, 1974.

COHN, A. Gastos sociais e políticas sociais nos anos 90: a persistência do padrão histórico de proteção social brasileiro. In: XXIV ENCONTRO ANUAL DA ASSOCIAÇÃO NACIONAL DE POS-GRADUAÇÃO EM CIÊNCIAS SOCIAIS (ANPOCS/GT Estrutura Social e Desigualdade). Petrópolis, 2000.

COSTA, A. M. Análise histórica do saneamento no Brasil. In: I EXPOSIÇÃO DE EXPERIÊNCIAS MUNICIPAIS NA ÁREA DE SANEAMENTO, 1996. Anais... Brasília: Assemae, 1996.

COSTA, A. M. Agenda política em saneamento ambiental: desafios para o controle social. In: SANTOS Jr.; BRITTO, A. L. \& PORTO, H. R. L. (Orgs.) Políticas de Saneamento Ambiental: inovações na perspectiva do controle social. Rio de Janeiro: Ippur-UFRJ/Fase, 1998. 
COSTA, A. M. et al. Impactos decorrentes de agravos relacionados a um saneamento ambiental inadequado sobre a mortalidade no Brasil. In: V CONGRESSO BRASILEIRO DE EPIDEMIOLOGIA, 2002, Curitiba. Anais... Rio de Janeiro: Abrasco, 2002.

COSTA, N. do R. Políticas Públicas, Justiça Distributiva e Inovação: saúde e saneamento na agenda social. São Paulo: Hucitec, 1998.

COUTINHO, E. S. F. Confiabilidade da informação sobre uso recente de medicamentos em urn estudo caso controle de base hospitalar. Cadernos de Saúde Pública, 15 (3): 553-558, 1999.

CREESE, A. Cost effectiveness of alternative strategies for poliomyelitis immunization in Brazil. Reviews of Infectious Diseases, 6 (suppl.2), may-june, 1984.

DE QUADROS, C. et al. Measles elimination in the Americas: evolving strategies. Journal of the American Medical Association, 275: 224-229, 1996.

DEMO, P. Política Social na Década de 60 e 70. Fortaleza: Edições UFC, 1981.

DESLANDES, S. F. Violência no cotidiano dos serviços de emergência hospitalar: representações, práticas, interações e desafios, 2000. Tese de Doutorado, Rio de Janeiro: Escola Nacional de Saúde Pública/Fundação Oswaldo Cruz.

DIAS, E. \& PELLEGRINO, J. Alguns ensaios com o "Gamexanne" no combate aos transmissores da doença de Chagas. Brasil Médico, 62: 185-190, 1948.

DOBSON, A. J. An Introdution to Generalized Linear Models. Grã-Bretanha: T. J. Press, 1990.

DOMINGUES, C. M. A. S. et al. Evolução do sarampo no Brasil e a situação atual. Informe Epidemiológico do SUS, jan.-mar. 1997.

DRAIBE, S. M. As políticas sociais brasileiras: diagnósticos e perspectivas. In: IPEA. Para a década de 90: prioridades e perspectivas de políticas públicas - políticas sociais e organização do trabalbo. Brasília. 1989. v.4.

DRAIBE, S. M. A política brasileira de combate à pobreza. In: VELLOSO, J. P. dos R. (Coord.) O Brasil e o Mundo no Limiar do Novo Século. Rio de Janeiro: José Olympio, 1998. v.2.

DRAIBE, S. M. Avaliação da descentralização das políticas sociais no Brasil: saúde e educação fundamental. Santiago: Cepal, 1998. (Série Reformas de Política Pública).

DRAIBE, $S$. M. A reforma dos programas sociais brasileiros: panoramas e trajetórias. In: XXIV ENCONTRO ANUAL DA ASSOCIAÇÃO NACIONAL DE PÓS-GRADUAÇÃO EM CIÊNCIAS SOCIAIS (ANPOCS/GT Política e Economia). Petrópolis, 2000.

DUARTE, E. C. et al. Epidemiologia das desigualdades em saúde no Brasil : um estudo exploratório. Brasilia: Opas, 2002.

DURKHEIM, É. O Suicídio. São Paulo: Editora Abril, 1980. (Coleção Pensadores).

ERTHAL, R. M. o Suicídio Tikuna no Alto Solimões: uma expressão de conflitos, 1998. Tese de Doutorado, Rio de Janeiro: Ensp/Fiocruz.

ESPING-ANDERSEN, G. The Three Worlds of Welfare Capitalism. Princeton: Princeton University Press, 1990.

FAGNANI, E. Política social e pactos conservadores no Brasil: 1964:92. Economia e Sociedade, 8 : 183-238, jun. 1997.

FAGNANI, E. Ajuste econômico e financiamento da política social brasileira: notas sobre o período 1993-98. Economia e Sociedade, 13: 155-178, dez. 1999. 
FEJJO, M. C. C. \& PORTELA, M. C. Variação no custo de internações hospitalares por lesões: os casos dos traumatismos cranianos e acidentes por armas de fogo. Cadernos de Saúde Pública, 17: 627-637, 2001.

FENNER, F. et al. Smallpox and its Eradication. Geneva: World Health Organization, 1988.

FERLAY, J. PARKIN, D. M. \& PISANI, P. Cancer Incidence and Mortality Worldwide. Lyon: World Health Organization/Iarc Press, 1998.

FERREIRA, E. Vacinação em massa contra a poliomielite, com vacina trivalente de vírus vivos atenuados. Jornal de Pediatria, 1962. v. 27, fascículo 3.

FIOCRUZ. ENSP. CLAVES. 0 custo do atendimento emergencial em hospitais municipais do Rio de Janeiro (HMMC e HMSF, 1996). Il Relatório da Pesquisa "O custo social e o preço humano da violência: um estudo da emergência hospitalar", 1997.

FLEURY, S. Iniquidades nas políticas de saúde pública: o caso da América Latina. Revista de Saúde Pública, 29 (3): 243-250, 1995.

FLORA, P. \& HEIDENHEIMER, A. J. The historical core and the changing boundaries of the Welfare State. In: FLORA, P. \& HEIDENHEIMER, A. J. (Eds.) The Development of Welfare States in Europe and America. Transaction Publishers, 1982.

FONSECA, M. G. Dinâmica Temporal da Epidemia de Aids no Brasil segundo Condição Socioeconômica, no período 1986-1998, 2002. Tese de Doutorado, Rio de Janeiro: Escola Nacional de Saúde Pública da Fundação Oswaldo Cruz.

FONSECA, M. G.; SZWARCWALD, C. L. \& BASTOS, F. I. Análise sócio-demográfica da epidemia de Aids no Brasil, 1989-1997. Revista de Saúde Pública, 2002. (No prelo).

FONSECA, M. G. et al. Aids e grau de escolaridade no Brasil: evolução temporal de 1986 a 1996. Cadernos de Saúde Pública, 16 (suppl. 1): 77-87, 2000.

FONSECA, M. G. P. \& BARREIRA, D. A evolução da mortalidade por Aids no país, segundo sua distribuição geográfica. Boletim Epidemiológico - Aids, XIII: 43-49, out.-dez. 2000. (Semana Epidemiológica 36 a 52).

FRANCO, L. J. \& ROCHA, J. S. Y. 0 aumento das hospitalizações por diabetes na região de Ribeirão Preto, no período 1988-97, Diabetes Clínica, 6: 108, 2002.

FRANCO, L. J. et al. Diabetes como causa básica ou associada de morte no estado de São Paulo, Brasil, 1992. Revista de Saúde Pública, 32: 237-245, 1998.

FRANCO, O. História da Febre Amarela no Brasil. Rio de Janeiro: Ministério da Saúde, 1976.

FRANCO, R. Social policies in transitional societies: is the latin american experience usefull? In: FRANCO, R., GERSTENFELD, P. \& COHEN, E. (Eds.) Social Policies and Socioeconomic Indicators for Transitional Economies. Santiago: ECLAC, 1998.

FREDERIKSEN, H. Feedbacks in economic and demographic transition. Science, 166: 837-847, 1969.

FRIAS, L. A. \& RODRIGUES, P. Brasil: tábuas-modelo de mortalidade e populações estáveis. Rio de Janeiro: IBGE, 1981.

FUNDAÇ̃̃O SESP. Vigilância da poliomielite no Brasil: nota preliminar. Boletim Epidemiológico, VIII: (23), 1976.

FUNDAÇÃO SESP. Poliomielite no Brasil em 1975 e 1976. Boletim Epidemiológico, IX: (41-42), 1977. 
FUNDAÇÃO SESP. Os laboratórios de diagnóstico da poliomielite. Boletim Epidemialógico, XIII: (20-21), 1981.

FUNDAÇÃo SESP. Sistema de vigilância epidemiológica da poliomielite no Brasil. Boletim Epidemiológico, XIII: (24-25), 1981.

FUNDAÇÃo SESP. Poliomielite, Brasil, 1981. Boletim Epidemiológico, XIV: (14), 1982.

FUNDAÇÃo SESP. Vigilância epidemiológica da poliomielite no Brasil, 1975-1980. Boletim Epidemiológico, XIV: (13), 1982.

GERSTEIN, H. C. Glucose: a continuos risk factor for cardiovascular disease. Diabetic Méd., 14: S25-\$31, 1997.

GOMES, F J. P. Programa nacional de profilaxia da raiva: considerações sobre o seu desenvolvimento - 1975-1978. Rev. Rundação Sesp, 25: 24-34, 1980.

GUERRA, M. J. \& DONAIRE, D. Estatística Indutiva: teoria e aplicações. São Paulo: LCT, 1991.

GUIMARÃES, C; SOUZA, J. M. P. \& MELLO JORGE, M. H. P. Mortalidade de adultos de 15 a 74 anos de idade em São Paulo, Botucatu e São Manoel (Brasil), Revista de Saúde Pública, 13 (suppl.2): 1-73. 1979.

GUZMÁN, J. M. Mortalidad infantil, neonatal y postneonatal en paises seleccionados de America Latina, nuevas tendencias? Santiago: Celade, 1985. (Mimeo.)

GUZMÁN, M. G. \& KOURI, G. Dengue: an update. The Lancet, 2: 33-42, 2001.

GUZMÁN, M. G.; KOURI, G. \& VALDES, L. Epiđemiological studies on dengue in Santiago de Cuba. Am. J. Epidemiol., 152: 793-799, 2000.

GWATKIN, D. R. Indications of change in developing country mortality trends: the end of an era? Population and Development Review, 6 (4): 615-644, 1980.

HOFFMANN, R. \& VIEIRA, S. Análise de Regressão: uma introdução à econometria. São Paulo: Hucitec, 1998.

HOPE, A. H. et al. Cardiovascular Medicine. In: Oxford Handbook of Clinical Medicine. Oxford: Oxford University Press, 1998.

HOPKINS, D. Princes and Peasants: smallpox in bistory. Londres: The University of Chicago Press, 1983.

INSTITUTO BRASILEIRO DE GEOGRAFIA E ESTATÍSTICA (IBGE). Censo Demográfico 1980. Rio de Janeiro: IBGE, 1980.

INSTITUTO BRASILEIRO DE GEOGRAFIA E ESTATISTICA (IBGE). Censo Demográfico 1991: resultados do universo relativos às características da população e do domicílio. Rio de Janeiro: IBGE, 1991.

INSTITLTO BRASILEIRO DE GEOGRAFIA E ESTATISTICA (IBGE). ESTUDO NACIONAL DE DESPESAS FAMILIARES (ENDEF). Dados Preliminares, 1975 v. I.

INSTITUTO NACIONAL DE ALIMENTAÇÃO E NUTRIÇÃO (INAN). Pesquisa Nacional de Saúde e Nutrição: resultados preliminares. Brasília, 1989.

INSTITUTO NACIONAL DE ALIMENTAÇÃO E NUTRIÇÃo (INAN). Pesquisa Nacional de Saúde e Nutrição: perfil de crescimento da população brasileira de 0-25 anos. Brasília, 1990.

IUNES, R. F. Impacto econômico das causas externas no Brasil: um esforço de mensuração. Revista de Saúde Pública, 31 (suppl. 4): 38-46, 1997. 
JAGUARIBE, H. Introdução ao Desenvolvimento Social. Rio de Janeiro: Paz e Terra, 1978.

JOINT NATIONAL. COMMITTEE. The sixth report of the joint national committee on prevention, dection, evaluation, and treatment of high blood pressure. Arch. Intern. Med., 157: 2414-2446, 1997.

KING, H.; AUBERT, R. E. \& HERMAN, W. H. Global burden of diabetes, 1995-2025. Diabetes Care, 21: 1414-1431, 1998.

KING, D. S. 0 Estado e as estruturas sociais de bem-estar em democracias industriais avançadas. Novos Estudos, 22, out. 1988. (Publicado originalmente em Theory and Society, 16 (6), nov. 1987.

LAURENTI, R. 0 perfil da mortalidade materna. In: MINAYO, M. C. S. (Org.) Os Muitos Brasis: saúde e população na década de 80. São Paulo/Rio de Janeiro: Hucitec/Abrasco, 1995.

LAURENTI, R.; FONSECA, L. \& COSTA Jr., M. L. Mortalidade por diabetes no município de São Paulo (Brasil): evolução em um período de 79 anos (1900-1978) e análise de alguns aspectos sobre associação de causas. Revista de Saúde Pública, 16: 77-91, 1982.

LAURENTI, R. et al. Estatísticas de Saúde. São Paulo: EPU, 1987.

LEBRÃO, M. L.; MELLO JORGE, M. H. P. \& LAURENTI, R. Morbidade hospitalar por lesões e envenenamentos. Revista de Saúde Pública, 31 (suppl. 4): 26-37, 1997.

LEBRÃo, M. L.; CARANDINA, L. \& MAGALDI, C. Análise das condições de saúde e de vida da população urbana de Botucatu, São Paulo (Brasil). IV- Morbidade referida em entrevistas domiciliares, 1983-1984. Revista de Sauide Pública, 25: 452-60, 1991.

LESSA, I. Aspectos sociais da mortalidade precoce (15-59 anos) por doenças cerebrovasculares. Arq. Neuropsiq., 48: 296-300, 1990.

LESSA, I. Tendência da mortalidade proporcional pelo diabetes mellitus nas capitais brasileiras, 1950 1985. Boletim da Oficina Sanitária Pan-A mericana, 113: 212-217, 1992.

LESSA, I. O Adulto Brasileiro e as Doenças da Modernidade: epidemiologia das doenças crônicas não-transmissíveis. 1. ed. São Paulo: Editora Hucitec/Abrasco, 1998.

LESSA, I.; ALMEIDA, F. A. A. \& ALVES, J. F. A. Prevalência de doenças crônicas em bairro de Salvador, Bahia, Brasil. Boletim da Oficina Sanitária Pan-Americana, 93: 376-387, 1982.

LESSA, I; MENDONÇA, G. A. S \& TEIXEIRA, M. T. B. Doenças crônicas não-transmissíveis no Brasil: dos fatores de risco ao impacto social. Boletim da Oficina Sanitária Pan-Americana, 120: 369-413, 1996:

LESSA, I. et al. Diabetes mellitus como causa básica e como causa associada de morte em Salvador, Brasil. Arquivos Brasileiros de Medicina, 60: 467-472, 1986.

LESSA, I. et al. Prevalência de dislipidemias na demanda laboratorial de três diferentes prestadores de assistência. Arq. Bras. Cardiol., 70: 331-335, 1998.

LIPIETZ, A. Towards a New Economic Order: postfordism, ecology and democracy. New York: Oxford University Press, 1992. (Publicado originalmente sob o título "Choisir L'audace, La Décuverte", 1989).

MALERBI, D. \& FRANCO, L. J. The Brazilian cooperative group on the study of diabetes prevalence: multicenter study of the prevalence of diabetes mellitus and impaired glucose tolerance in the urban Brazilian population aged 35-69 yr. Diabetes Care, 15: 1509-1516, 1992.

MALLOY, J. M. The Politics of Social Security in Brazil. Pittsburg: University of Pittsburg Press, 1979. 
MARINS, J. R. P. et al. Dramatic improvement in survival among adult Brazilian Aids patients. The Lancet, 2002. (No prelo).

MARQUES, A. C. Migrações internas e as grandes endemias. Rev. Bras. Malariol. D. Trop., 31: 137$158,1979$.

MARTINE, G. Evolução e perspectivas da migração interna no Brasil. In: Doenças e Migração $H u$ mana. Brasília: Centro de Documentação do Ministério da Saúde, 1982.

MARTINE, G. A resolução da questão social no Brasil: experiências passadas e perspectivas futuras. In: IPEA. Para a década de 90: prioridades e perspectivas de politicas públicas - políticas sociais e organização do trabalbo. Brasília, 1989. v.4.

MARTINS DA SILVA, M. \& SYVERTON, J. Poliomyelitis survey in Rio de Janeiro. Public Health Reports, 71: 4, apr. 1956.

MATIDA, L. H. Aids: sobrevida de crianças com idade até 12 anos completos, Brasil, em casos diagnosticados no período 1983-1998. Relatório final, s.d. (Mimeo.)

MATOS, 0. C. Econometria Básica: teoria e aplicações. São Paulo: Atlas, 1995.

MCGOVERN, P. et al. Trends in mortality, morbidity and risk factor levels for stroke from 1960 to 1990: the Minnesota heart survey. Journal of the American Medical Association, 268: 753$759,1992$.

MCKEOWN, T. The Role of Medicine: dream, mirage or nemesis? Oxford: Basil Blakwell, 1979.

MELLO JORGE, M. H. P. de \& GOTLIEB, S. L. D. As Condições de Saúde no Brasil: retrospecto de 1979 a 1995. Rio de Janeiro: Editora Fiocruz, 2000.

MELLO JORGE, M. H. P. de; GAWRYSZESKI, V. P. \& LATORRE, M. R. D. 0. Acidentes e violência no Brasil. I - análises dos dados de mortalidade. Revista de Saúde Pública, 31 (suppl 4): 5-25, 1997.

MELO, M. S. et al. Causas múltiplas de morte em diabéticos no município de Recife, 1987. Revista de Saúde Pública, 25: 435-442, 1991.

MELO, M. A. Políticas públicas urbanas para a nova década: uma agenda de questões. Trabalho apresentado no Seminário "Cinco Painéis sobre o Desenvolvimento Brasileiro". BNDES, 2002. 32p. (Mimeo.)

MERCY, J. A. Public health policy preventing violence. Health Affairs, 12: 7-29, 1993.

MINAYO, M. C. S. A autoviolência, objeto da sociologia e problema de saúde pública. Cadernos de Saúde Pública, 14 (2): 421-428, 1998.

MINAYO, M. C. S. \& DESLANDES, S. F. A complexidade das relações entre drogas, álcool e violência. Cadernos de Saúde Pública, 14 (1): 35-42, 1998.

MINISTERIOS DE SALUD DE BRASIL, COSTA RICA, CHILE Y ECUADOR, Y LA ORGANIZACIÓN PANAMERICANA DE LA SALUD. Tasas de seroconversion y títulos de anticuerpos inducidos por la vacina antisarampionosa en niños latinoamericanos de seis a doce meses de edad. Simposio Internacional sobre inmunización contra el sarampion. Publicación scientifica n. 477. Washington: Opas, 1985.

MONTEIRO, C. A. \& CONDE, W. L. Tendência secular da desnutrição e da obesidade na cidade de São Paulo (1974-1996). Revista de Saúde Pública, 34: 52-61, 2000.

MONTEIRO, C. A.; SOUZA, A. L. M. \& MONDINI, L. Velhos e Novos Males de Saúde no Brasil. São Paulo: Hucitec/Nupens/USP, 1995. 
MONTEIR0, C. A.; BENÍCIO, M. H. D. \& FREITAS, I. C. M. Melhoria em indicadores de saúde associados à pobreza no Brasil dos anos 90: descrição, causas e impacto sobre as desigualdades regionais. NUPENS/USP. (Série: A Trajetória do Desenvolvimento Social no Brasil no 1/1997).

MORBIDITY AND MORTALITY WEEKLY REPORT (MMWR). Changes in mortality from heart failure United States, 1980-1995. Morbidity and Mortality Weekly Report, 47: 633-637. 1998.

NASCIMENTO, M. V. L. A Poliomielite e as Viagens Internacionais: o risco de reintrodução no Brasil. Brasília: Funasa/Ministério da Saúde, 2001.

NATIONAL HIGH BLOOD PRESSURE EDUCATION PROGRAM. Working group. report on primary prevention of hypertension. Arch. Int. Med., 153: 186-208, 1993.

NICHOLLS, E. S.; PERUGA, A. \& RESTREPO, H. E. Cardiovascular disease mortality in the Americas. Rapp. Trimest. Statist. Sanit. Mond., 46: 134-150, 1993.

OFFE, C. \& LENHARDT, G. Social policy and the theory of the State. In: OFFE, C. \& KEANE, J. (Eds.) Contradictions of the Welfare State. 4. ed. MIT Press. Massachussetts, 1990. (Publicado originalmente em Kölner Zeischrift für Soziologie und Sozialpsychologie, 19: 98-127, 1977).

OLIVEIRA, M. I. et al. Measles virus isolated in Brazil: imported case from Japan. Virus Review and Research, 6: 141-142, 2001.

OMETTO, A. M. H.; FURTUOSO, M. C. 0. \& SILVA, M. V. Economia brasileira na década de oitenta e seus reflexos nas condições de vida da população. Revista de Saúde Pública, 29 (5): 403-415, 1995.

OMRAN, A. R. The epidemiologic transition: a theory of the epidemiology of population change. Milbank Mem. Fund., 49: 509-583, 1971.

OMRAN, A. R. The epidemiologic transition in the Americas. Pan-American Health Organization \& University of Maryland, 1996.

ORGANIZAÇÃO MUNDIAL DA SAÚDE (OMS). CID - 10. 3. ed. São Paulo: Editora da Universidade de São Paulo, 1996. (Tradução Centro Colaborador da OMS para a Classificação de Doenças em Português.)

ORGANIZACION PANAMERICANA DE LA SALUD (OPAS). Las Condiciones de Salud de las Americas. Washington D.C.: Opas, 1990. v. I. (Public. Cient. no.524).

ORGANIZAÇÃO PANAMERICANA DE LA SALUD (OPAS). La Salud en las Américas. Washington D.C.: Opas, 1998. (Publ. Científica n. 569).

PAN AMERICAN HEALTH ORGANIZATION. Handbook of resolutions of the governing bodies of the Pan American Health Organization. Washington, D.C., 1971.

PAN AMERICAN HEALTH ORGANIZATION. Ventures in World Health: the memoirs of Fred Lowe Soper. John Duffy Editor, 1977. (Scientific Publication n. 355).

PANNUTI, C. S. et al. Measles antibody prevalence after mass vaccination in São Paulo, Brazil. Bull. World Health Organization, 69: 557-560. 1991.

PASSOS, A. D. C. \& FIALHO, R. R. Malária: aspectos epidemiológicos e de controle. Rev. Soc. Bras. Méd. Trop., 31 (2): 93-105, 1998.

PATRIARCA, P. A. et al. Randomised trial of alternative formulations of oral poliovaccine in Brazil. The Lancet, 1 (8583): 429-433, 1988.

PEDREIRA DE FREITAS J. L. Importância do expurgo seletivo dos domicílios e anexos para a profilaxia da moléstia de Chagas pelo combate aos triatomíneos. Arg. Hig. S. Paulo, 28: 217-272, 1963. 
PELIANO, A. M., RESENDE, L. F. \& BEGIN, N. Comunidade solidária: uma estratégia de combate à fome e à pobreza. Planejamento e Políticas Públicas, 12, jun.-dez. 1995.

PINHEIRO, V. C. Modelos de desenvolvimento e políticas sociais na América Latina em uma perspectiva histórica. Planejamento e Políticas Públicas, 12. jun.-dez. 1995.

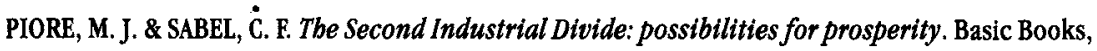
1984.

PONTES, C. A. A. et al. Impactos decorrentes de agravos relacionados a um saneamento ambiental inadequado sobre o perfil de morbidade da população, Brasil, 1996 a 2000. In: V CONGRESSO BRASILEIRO DE EPIDEMIOLOGIA, 2002, Curitiba. Anais... Recife: Abrasco, 2002.

PRZERWORSKY, A. \& WALLERSTEIN, M. O capitalismo democrático na encruzilhada. Novos Estudos, 22, out. 1988. (Publicado originalmente em Democracy, jul. 1982).

PUFFER, A. \& SERRANO, C. V. Patterns of Mortality in Childhood. Washington: D.C.: PAHO, 1973 (Publicação Científica n. 262.)

RABINOVICH J. E. et al. Probability of transmission of Chagas disease by Triatoma infestans (Hemiptera: Reduviidae) in an endemic area of Santiago del Estero, Argentina. Bull. World Health Organization, 68: 737-746, 1990.

REZENDE, J. M. Notas históricas e filológicas sobre a palavra dengue. Rev. Pat. Trop., 26: 375-380, 1997.

RISI JR., J. B. Control of measles in Brasil. Rev. Infect. Dis., 5: 583-587, 1983.

RISI JR., J. B. Controle da poliomielite no Brasil. A Saúde no Brasil, 1 (1) : 6-17, jan.-mar. 1983.

ROMAÑA, C.; HABLAOS, J. W. Acción del "Gamexanne" sobre los triatomídeos. Control domiciliario. Anales del Instituto de Medicina Regional, 2: 95-106, 1948.

RUESCHENMEYER, D. \& EVANS, P. The state and economic transformation: toward an analysis of the conditions underlying effective intervention. In: EVANS, P.; RUESCHENMEYER, D. \& SKOCPOL, T. (Eds.) Bringing the State Back. Cambridge: Cambridge University Press, 1985.

RUFFINO NETO, A. \& PEREIRA, J. C. Mortalidade por tuberculose e condições de vida: 0 caso do Rio de Janeiro. Saúde em Debate, Rio de Janeiro: Cebes, n.12 1981.

SABIN, A. Oral poliomyelitis vaccine: achievements and problems in worldwide use. Bulletin of the International Pediatric Association, 2 (2): 6-17, apr. 1977.

SANTOS, J. L. F. Demografia: estimativas e projeções. Fauusp/Fundação para Pesquisa Ambiental, 1978.

SCHNEIDER, M. C. et al. Controle da raiva no Brasil de 1980 a 1990. Revista de Saúde Pública, 30 (2): 196-203, 1996.

SCHOFIELD, C. J. The behaviour Triatominae (Hemiptera, Reduviidae): a review. Bull. Ent. Res., 69: 363-379, 1979.

SCORZELLI Jr., A. Poliomielite no Rio de Janeiro (Guanabara): estudo epidemiológico. Arquivos de Higiene, 22, 1966.

SILVEIRA, A. C. Dengue: aspectos epidemiológicos e de controle. Rev. Soc. Bras. Med. Trop., 31 (supl. II): 5-14, 1998.

SILVEIRA, A. C. Current situation with the control of vector-borne Chagas' disease transmission in the Americas/Situação do controle da transmissão vetorial da doença de Chagas nas Américas. In: Atlas of Chagas' disease vectors in the Americas. Rio de Janeiro: Fiocruz Editorial, 1999. v. III. 
SILVEIRA, A. C. Profilaxia. In: Trypanosoma Cruzi e Doença de Cbagas. 2.ed. Rio de Janeiro: Guanabara-Koogan, 1999.

SILVEIRA, A. C. 0 Controle de Aedes aegypti, vetor do dengue e da febre amarela urbana na região das Américas: avanços, dificuldades, retrocessos, perspectivas. 2002. (No prelo).

SILVEIRA, A. C. \& REZENDE, D. F. Epidemiologia e controle da transmissão vetorial da doença de Chagas no Brasil. Rev. Soc. Bras. Med. Trop., 27 (suppl. III): 11-22, 1994.

SILVEIRA, A. C. \& REZENDE, D. F. Avaliação da estratégia global de controle integrado da malária no Brasil. Brasília: Opas, 2001.

SIMÕES, C. C. S. Mortalidade infantil e na infância e riscos de mortalidade associada ao comportamento reprodutivo. In: BEMFAM/IBGE/DHS/USAID/FNUAP/UNICEF. Pesquisa Nacional sobre Demografia e Saúde 1996. Rio de janeiro, 1997.

SIMÕES, C. C. S. Brasil: estimativas da mortalidade infantil por microrregiões e municípios. Brasília: Ministério da Saúde, 1999.

SIMÕES, C. C. S. Perfis de Saúde e de Mortalidade no Brasil: uma análise de seus condicionantes em grupos populacionais especificos. Brasília: 0pas/0MS, 2002.

SIMÕES, C. C. S. \& OLIVEIRA, L. A. P. A situação da fecundidade: determinantes gerais e características da transição recente. In: Perfil Estatístico de Crianças e Mães no Brasil. Rio de Janeiro: IBGE, 1988.

SIMÕES, C. C. S. \& OLIVEIRA, L. A. P. A saúde infantil na década de 90. In: Infância Brasileira nos Anos 90. Rio de Janeiro: IBGE, 1997.

SKABA, M. M. V. F. 0 vício da adrenalina: etnografia da violência num hospital de emergência, 1997. Dissertação de Mestrado, Rio de Janeiro: Escola Nacional de Saúde Pública/Fundação Oswaldo Cruz.

SOUZA, C. Redemocratização, federalismo e gasto social no Brasil: tendências recentes. In: XXIV ENCONTRO ANUAL DA ASSOCIAÇÃO NACIONAL DE PÓS-GRADUAÇÃO EM CIENCIAS SOCIAIS (ANPOCS/GT Estrutura Social e Desigualdade). Petrópolis, 2000.

SOUZA, E. R. Homicídios: metáfora de uma nação autofágica, 1995. Tese de Doutorado, Rio de Janeiro: Escola Nacional de Saúde Pública.

SOUZA, E. R. Mortalidade por homicídios na década de 80: Brasil e capitais de regiōes metropolitanas. In: BARRETO, M. L. (Org.) Epidemiologia, Serviços e Tecnologias em Saúde. Rio de Janeiro: Fiocruz/Abrasco, 1998. (Série Epidemiológica 3).

SOUZA, E. R. \& MINAYO, M. C. S. 0 impacto da violência social na saúde pública do Brasil: década de 80. In: MINAYO, M. C. S. Os Muitos Brasis: saúde e população na década de 80. São Paulo/ Rio de Janeiro: Hucitec/Abrasco, 1999.

SOUZA, M. M. C. A transposição de teorias sobre a institucionalização do Welfare State para o caso dos países subdesenvolvidos. Brasília: Ipea, 1999. (Texto para Discussão 695).

SUPLICY, E. M. \& NETO, B. A. Políticas sociais: o programa comunidade solidária e o programa de garantia de renda minima. Planejamento e Políticas Públicas, 12, jun.-dez. 1995.

SZWARCWALD, C. L. \& CARVALHO, M. F. Estimativa do número de indivíduos de 15 a 49 anos infectados pelo HIV, Brasil, 2000. Boletim Epidemiológico Aids, ano XIV, (1): 35-40, jan.-mar. 2001. (CNDST/Aids).

SZWARCWALD, C. L. Aspectos da epidemia de Aids na região Sul do Brasil, 1987-98: evidências de crescimento diferenciado. Brasília: CNDST/Aids, 2001. (Mimeo.) 
SZWARCWALD, C. L; BASTOS, F. I. \& CASTILHO, E. A. The dynamic of the Aids epidemic in Brazil: a space time analysis in the period 1987-1995. Brazilian Journal of Infectious Disease, 2: 175-186, 1998.

TAVARES, L. Política social e pobreza: o Brasil no contexto latino-americano. Rio de Janeiro: FRJ. (Mimeo.)

THE BRAZILIAN COOPERATIVE GROUP on the Study of Diabetes Prevalence: Multicenter study of the prevalence of diabetes mellitus and impaired glucose tolerance in the urban brazilian population aged 30-69 years. Diabetes Care, 15: 1509-1526, 1992.

THE VICTORA DECLARATION. Bridging the Gasp: science and police in action. Declaration of the Advisory Board. Victora, Canadá, may 28, 1992.

TORQUATO, M. T. C. G. et al. Prevalence of diabetes mellitus, impaired glucose tolerance and cardiovascular risk factors in the urban adult population of Ribeirão Preto-SP, Brazil. Diabetes Research and Clinical Practice, 50 (suppl. 1): S140, 2000.

T'RUSSELL, T. J. A re-estimation of the multiplying factors of the Brass technique for determining childhood survivorship rates. Population Studies, 19 (3): 97-107, 1975.

TUOMILEHTO, J. et al. Prevention of type 2 diabetes mellitus by changes in life-style among subjects with impaired glucose tolerance. New England Journal of Medicine, 344: 1343-1350, 2001.

UEMURA, K. \& PIZA, Z. Trends in cardiovascular disease mortality in industrialized countries since 1950. World Health Statistics Quartely, 41: 155-178, 1988.

VACCA, G. Estado e mercado, público e privado. Lua Nova, 24, set. 1991. (Publicado originalmente em Tra Italia e Europa: politiche e cultura dell'alternativa, Franco Angeli, 1991).

VASCONCELOS, P. F. C. et al. Serious adverse events associated with yellow fever 17DD vaccine in Brazil: a report of two cases. The Lancet, 58: 91-97.

VERAS, C. M. T. \& MARTINS, M. S. A confiabilidade dos dados nos formulários de autorização de internação hospitalar (AIH), Rio de Janeiro, Brasil. Cadernos de Saúde Pública, 10 (3): 339355, 1994.

VETTER, D., SIMÕES \& CELSO, C. S. 0 acesso à infra-estrutura de saneamento básico e mortalidade. Revista Brasileira de Estatistica, 42 (165): 17-35, 1981.

VICTORA, C. G. et al. Explaining trends in inequities: evidence from Brazilian child health studies The Lancet, 356: 1093-1098, 2000.

WARREN, A. J. Landmarks in the conquest of yellow fever. In: GEORGE, K. (Ed.) Yellow Fever. Strode, 1951.

WEIR, M. \& SKOCPOL, T. State structures and the possibilities for "Keynesian" responses to the great depression in Sweden, Britain and the United States. In: EVANS, P., RUESCHENMEYER, D. \& SKOCPOL, T. (Eds.) Bringing the State Back. Cambridge: Cambridge University Press, 1985.

WILSON, D. Contribuição para o Conhecimento da Epidemiologia do Diabetes Melito: aspectos de sua prevalência na cidade de Jarinu, estado de São Paulo, 1964. Tese de Livre-Docência, São Paulo: Faculdade de Higiene e Saúde Pública, Universidade de São Paulo.

WILSON, D.; PIRES, C. D. A. \& MOREIRA, F. O. P. Estudos sobre as provas de tolerância à glicose potencializadas em reclusos da penitenciária do estado de São Paulo. Arquivos da Faculdade de Higiene e Saúde Pública de São Paulo, 20: 129-137, 1966.

WILSON, G. L. Suicidal behavior-clinical considerations and risk factors. Journal of Consulting and Clinical Psychology, 59 (6): 869-873, 1991. 
WHO. MONICA PROJECT. Principal Investigators. The World Health Organization MONICA Project (monitoring trends and determinants in cardiovascular disease): a major international collaboration.J. Clin. Epidemiol., 41: 105-114, 1988.

WORLD HEALTH ORGANIZATION (WHO). Preventing and controlling drug abuse. World Health Statistics Quartely, 36(3/4): 27-37, 1983.

WORLD HEALTH ORGANIZATION (WHO). World Health Report 2000: making a difference. Geneva: WHO, 2000.

WORLD HEALTH ORGANIZATION (WHO). Dengue and dengue hemorrhagic fever. Report on global surveillance of epidemic-prone infectious diseases. WHO/CDS/CSR/ISR/2000.1), 2000.

WORLD HEALTH ORGANIZATION (WHO). Salud mental: nueva conecimentos, nuevas esperazas. Organização Mundial de Saúde, 2001. (Informe sobre la salud en el mundo).

WORLD HEALTH ORGANIZATION (WHO). Prevención y control de la fiebre dengue y la fiebre hemorrágica dengue. In: $55^{2}$ ASSEMBLEA MUNDIAL DE LA SALUD. Punto 13.14: (WHA 55.17), 2002.

WORLD HEALTH ORGANIZATION (WHO). Global measles mortality reduction and regional elimination strategic plan 2001-2005. WHO/N\&B/01.15.

YUNES, J. \& RAJS, D. Tendencia de la mortalidad por causas violentas en la población general y entre los adolescentes y jóvenes de las Américas. Cadernos de Saúde Pública, 10 (suppl. 1): 88$125,1994$.

ZHANG, J. et al. Padrões etários de fatores relacionados a acidentes de tráfego fatais: enfoque sobre motoristas jovens e idosos. Revista Abramet, 35: 42-47, 2000. 


\section{3 \\ Evolução das Políticas \\ e do Sistema de Saúde No BrasiL}

Otávio Azevedo Mercadante Coordenador

Alfredo Schechtman • Bianca Antunes Cortes • Ermenegyldo Munhoz Junior • Eugênio Vilaça Mendes • Julio Alberto Wong Un • Marcelo Medeiros - Maria do Socorro A. Lemos • Miguel Malo Serrano • Ricardo Henrique Sampaio Meirelles • Roberto Passos Nogueira • Sérgio Piola • Solon Magalhães Vianna • Valeska Carvalho Figueiredo 


\section{Antecedentes}

0 seguro social surgiu no Brasil em 1923 com a promulgação, pelo Presidente Artur Bernardes, da Lei $\mathrm{n}^{\circ} \mathbf{4 . 6 8 2}$ de 24 de janeiro, de autoria do Deputado Eloy Chaves. Com esta lei ficou instituído o sistema de Caixas de Aposentadorias e Pensão (CAPs), que atendeu, em um primeiro momento, aos trabalhadores ferroviários e, posteriormente, aos marítimos e estivadores.

Ao final de 1932, existiam 140 CAPs com quase 19 mil segurados ativos, 10.300 aposentados e aproximadamente 8.800 pensionistas. Entre as prestações oferecidas aos segurados das CAPs, constavam, além das de natureza previdenciária, a assistência médica e o fornecimento de medicamentos. Mas havia grandes diferenças entre os planos de benefícios, porque inexistiam regras comuns de funcionamento técnico e administrativo. Cada órgão estabelecia seu regulamento, que refletia parcialmente os anseios de cada segmento da classe trabalhadora e dependia da capacidade de receita disponível por meio das contribuições.

Em substituição ao sistema extremamente fragmentário das CAPs, foram fundados os Institutos de Aposentadoria e Pensão (IAPs), congregando o conjunto dos trabalhadores de um dado ofício ou setor de atividade. 0 primeiro Instituto, destinado aos funcionários públicos federais, foi criado em 1926, mais tarde denominado Instituto de Previdência e Assistência dos Servidores do Estado (IPASE). 0 último a ser criado foi o dos Ferroviários e Empregados em Serviços Públicos (IAPPESP), em 1953.

$\mathrm{Na}$ assistência à saúde, a maior inovação aconteceu em 1949, durante o segundo governo Vargas, quando foi criado o Serviço de Assistência Médica Domiciliar de Urgência (Samdu). A importância histórica desse evento decorre de três características inovadoras da iniciativa: 0 atendimento médico domiciliar até então inexistente no setor público, embora comum na prática privada; o financiamento consorciado entre todos os IAPs e, principalmente, $o$ atendimento universal ainda que limitado aos casos de urgência. 
Apesar de 0 atendimento médico ser uma das prerrogativas dos beneficiários da previdência, desde a promulgação da Lei Elloy Chaves, as legislações dos vários IAPs revelam que os serviços de saúde tinham importância secundária e restrições que variavam de órgão para órgão. Assim, no Instituto dos Marítimos (LAPM), o período de internação era limitado a trinta dias, e a despesa do Instituto com atenção médica não poderia ultrapassar $8 \%$ da receita do ano anterior. Já em outros IAPs, como o dos industriários e o dos trabalhadores em transportes e cargas, a atenção médica poderia implicar a cobrança de contribuição suplementar. Dessa forma, as disparidades normativas entre os IAPs contribuíram para que surgissem reivindicações em favor de um sistema de previdência unificado e menos desigual. Mas existiam vozes contrárias que viam, na unificação dos IAPs, a perda de poder por parte dos trabalhadores e o risco de centralização e concentração de poder no Estado.

Esse cenário originou uma solução intermediária. A Lei Orgânica da Previdência Social (Lops - Lei $n^{0} 3807$ de 26/8/1960), posteriormente regulamentada pelo Decreto $\mathrm{n}^{2} 48.959$, em setembro do mesmo ano, uniformizou as regras, mas manteve a organização institucional segmentada. De qualquer forma, a promulgação da Lops trouxe um avanço significativo no sentido de viabilizar a futura unificação da previdência social, visto que uniformizava os tipos de benefícios concedidos, a forma de contribuição para o financiamento do sistema e os procedimentos administrativos dos institutos. A vigência da Lops, contudo, não corrigiu todas as distorções originárias da multiplicidade de institutos: após sua promulgação ainda prevalecia uma falta de uniformidade na distribuição dos gastos entre os diversos programas. Por exemplo; enquanto, o instituto dos bancários despendia $33 \%$ do seu orçamento em assistência médica, no instituto dos industriários esse percentual era inferior a 8,5\%. Entretanto, havia ociosidade nos serviços de saúde oferecidos por certos institutos, sem que os trabalhadores pertencentes a outras categorias pudessem ter acesso a eles. 
Em que pese o crescimento gradual do número de categorias profissionais e do elenco de benefícios em quatro de décadas, a previdência social, na primeira metade dos anos 60 , ainda estava longe da universalização. Em 1960, no final do período desenvolvimentista de Kubitschek, os segurados da previdência somavam pouco mais de 5 milhões (dos quais 4 milhões eram contribuintes ativos e 0 restante composto por aposentados e pensionistas), ou seja, apenas $7,3 \%$ de uma população da ordem de 70 milhões.

Enquanto a assistência médica evoluía de forma segmentada e restrita aos contribuintes urbanos da previdência social, no âmbito da saúde pública surgia a primeira mudança na cultura campanhista de atuação verticalizada do governo federal com a criação, em 1942, do Serviço Especial de Saúde Pública (SESP). Esse serviço, criado em função do acordo entre os governos do Brasil e dos Estados Unidos, tinha por objetivo fundamental proporcionar o apoio médico-sanitário às regiões de produção de materiais estratégicos que representavam, na época, uma inestimável contribuição do Brasil ao esforço de guerra das democracias no desenrolar da II Guerra Mundial. Por isto, seu espaço geográfico inicial de atuação limitou-se à Amazônia (produção de borracha), ao estado de Goiás e ao Vale do Rio Doce (minérios). Seu primeiro plano de trabalho foi esboçado na III Conferência do Ministro do Exterior de 21 Repúblicas Americanas, realizada no Rio de Janeiro em 1942.

No decorrer de sua existência, o Sesp (transformado, em 1960, em fundação do Ministério da Saúde) destacou-se pela atuação em áreas geográficas distantes e carentes e pela introdução de inovações na assistência médico-sanitária, tais como técnicas de programação e avaliação e métodos de capacitação de pessoal em saúde pública. Foi também pioneiro na atenção básica domiciliar, com o uso de pessoal auxiliar e, sobretudo, na implantação de redes hierarquizadas de atenção integrada à saúde, proporcionando serviços preventivos e curativos, inclusive internação em especialidades básicas em suas Unidades Mistas. A atuação bem-sucedida e o decorrente prestígio como organização, deve-se em grande medida à gestão pro- 
fissional viabilizada pela adoção de regime de trabalho em tempo integral e dedicação exclusiva de seus quadros.

Foi no período 1966-1976 que se consolidou a duplicidade de responsabilidades federais no campo da saúde, divididas entre o Ministério da Saúde (MS) e o Ministério da Previdência Social. Isto porque a fusão das instituições de seguro social fortaleceu a previdência social tanto administrativa como, sobretudo, financeira e politicamente, contribuindo para o fracasso das tentativas integracionistas conduzidas na órbita do Ministério da Saúde.

0 Instituto Nacional de Previdência Social (INPS) foi criado pelo Decreto Lei $\mathrm{n}^{2} 72$ de 21/11/1966, com o objetivo central de corrigir os inconvenientes da segmentação institucional e, com isto, aumentar a eficiência do sistema. Foram ainda introduzidas algumas modificações na Lops e no extinto o SAMDU. A despeito da justificativa racionalizadora, a rapidez e eficácia da fusão podem ser atribuídas fundamentalmente ao instrumento autoritário (Decreto-Lei) que a gerou, em plena vigência do regime de exceção instaurado em abril de 1964.

Este período registra também o maior avanço em termos de extensão de cobertura, com a incorporação da população rural, ainda que em regime diferenciado, tanto em benefícios quanto na de forma de contribuição. A assistência médico-hospitalar aos trabalhadores rurais foi condicionada, a partir de 1971, à disponibilidade de recursos orçamentários. A mesma lei determinou que a "gratuidade" seria total ou parcial segundo a renda familiar do trabalhador. Toda a legislação previdenciária foi estabelecida com a Consolidação das Leis da Previdência Social (CLPS), de 1976. A assistência médico-hospitalar previdenciária continuou sob a responsabilidade do Ministério do Trabalho e Previdência Social (MPAS).

Objeto de ampla polêmica em 1968 (governo Costa e Silva), o assim denominado Plano Nacional de Saúde (PNS) foi elaborado por iniciativa do então Ministro da Saúde, Leonel Miranda, caracterizando-se como a principal 
preocupação para o setor saúde após a instauração do regime de 1964. 0 PNS se notabilizou por algumas características centrais que, se implementadas, teriam modificado substancialmente o sistema de saúde vigente no país, entre elas, a universalização do acesso e a integração da assistência médica no Ministério da Saúde, o que foi objeto de forte resistência, ainda que não explícita, da área previdenciária. Aspectos particularmente polêmicos do plano incluíam a privatização da rede pública e a adoção do preceito de livre escolha, pelo paciente, do profissional e hospital de sua preferência, sendo a remuneração aos provedores proporcional ao número e complexidade dos procedimentos.

A iniciativa mobilizou entidades representativas das profissões de saúde, organizações sindicais de trabalhadores, governos estaduais, como os de São Paulo e Rio Grande do Sul, entre outros, que manifestaram oposição e perplexidade ao inusitado da proposta. A repercussão negativa na mídia e, certamente, a resistência velada da área previdenciária, - já que a proposta implicava perda de poder da medicina previdenciária em favor do Ministério da Saúde - conduziram o governo a cancelar o Plano.

No vácuo deixado pelo cancelamento do PNS, o novo ministro da Saúde, Mário Machado de Lemos, tentou implementar um conjunto de princípios e diretrizes destinados a orientar a ação e decisão do governo, definindo os postulados básicos a serem observados na institucionalização e implementação do Sistema Nacional de Saúde (SNS). A prestação de serviços gerais de saúde seguiria alguns princípios, que hoje regem o Sistema Único de Saúde (SUS), tais como a universalização da assistência, a regionalização dos serviços e a integração entre serviços preventivos e de assistência individual. Ao forçar, entretanto, o cumprimento do disposto no art. 156 do Decreto Lei $\mathrm{n}^{\mathrm{0}}$ 200, de 25 de fevereiro de 1967, ou seja, ao assumir de fato e de direito a competência para implantar e coordenar a Política Nacional de Saúde, o Ministério de Saúde provocou forte antagonismo. A integração no nível federal adviria da criação do Instituto Nacional de Assistência Médica, autarquia vinculada ao Ministério da Saúde e que absorveria todos os organismos até então na órbita da previdência social (MPAS). 
0 projeto abortou e os elementos que estavam no seu cerne (universalização, regionalização, hierarquização da rede e comando único) só seriam retomados quinze anos mais tarde, na VIII Conferência Nacional de Saúde e na Assembléia Nacional Constituinte.

Se a busca de um sistema de saúde universal fracassou nas tentativas hegemônicas do Ministério da Saúde, o Ministério da Previdência (ministro Nascimento e Silva), um ano depois, deu um passo importante com o Plano de Pronta Ação (PPA). Este passo, embora coerente com a estratégia gradualista de extensão de cobertura adotada pela previdência social, rompeu - mais uma vez (a primeira foi com a criação do SAMDU) - a lógica da vinculação do direito de assistência médica à condição de contribuinte da previdência.

0 PPA consistia num conjunto de mecanismos normativos cuja finalidade maior, como explicitado então, era proporcionar condições para que fosse progressivamente atingida a universalização da previdência social. Sua principal inovação foi a determinação de que os casos de emergência deveriam ser atendidos por todos os serviços próprios e contratados independentemente do paciente ser ou não um beneficiário (segurado ou dependente) da previdência. Quando o atendido não fosse previdenciário, as despesas com os serviços prestados limitar-se-iam à duração do estado de emergência.

A importância histórica dessa política está no fato de que, pela primeira vez após a extinção do SAMDU, a previdência social admitia o uso de seus recursos no atendimento universal. Isto só foi possível em um contexto criado pelas repetidas denúncias na imprensa sobre omissão de socorro que, em alguns casos, tinha conseqüências trágicas, a que acrescia a existência de uma relativa folga no caixa previdenciário. Na década de 1970 , as receitas previdenciárias cresciam em ritmo superior ao da economia como um todo, já que o dinamismo do sistema dependia, sobretudo, dos setores mais modernos da economia, em que as relações formais de trabalho estavam mais presentes. Este aspecto e a importância política de mostrar a face social do regime autoritário também explicam, em alguma medida, outras 
políticas de ampliação de direitos sociais da época, tais como a extensão da previdência ao trabalhador rural e a criação do beneficio mensal aos idosos não contribuintes.

Como era previsível, dada a vigência da modalidade de remuneração dos serviços contratados por unidade de serviço, adotada pela previdência na sua pactuação com rede privada, a universalização do atendimento de emergência, na década de 1970, gerou inúmeras distorções, entre as quais um excesso de internações hospitalares, principalmente nos estados do Rio de Janeiro, São Paulo, Minas Gerais, Rio Grande do Sul e Santa Catarina, conforme reconheceu o próprio presidente do INSS.

Em 1975, o governo federal (ministro da Saúde: Paulo de Almeida Machado) toma a iniciativa de organizar o setor saúde sob forma sistêmica. Promulgada em 17 de julho de 1975, a Lei $n^{0} 6229$, dispondo sobre organização do SNS, definiu dois grandes campos institucionais: 1) o do Ministério da Saúde, de caráter eminentemente normativo, com ação executiva preferencialmente (sic) voltada para as medidas e os atendimentos de interesse coletivo, inclusive vigilância sanitária; e 2) 0 do Ministério da Previdência e Assistência Social, com atuação voltada principalmente (sic) para 0 atendimento médico-assistencial individualizado.

o Sistema Nacional de Saúde, então instituído oficialmente pela Lei $\mathbf{n}^{\circ}$ 6229 de 1975, com o objetivo principal de corrigir a multiplicidade institucional descoordenada no setor público, ficou conceituado como: "0 complexo de serviços do setor público e do setor privado, voltados para as ações de interesse de saúde, organizado e disciplinado nos termos desta Lei, abrangendo as atividades que visem a promoção, proteção e recuperação da saúde".

Caberia ao Conselho de Desenvolvimento Social (CDS) apreciar a Política Nacional de Saúde formulada pelo Ministério da Saúde, bem como os planos setoriais do MPAS e MEC, no que se refere, respectivamente, à assistência médica e à formação de recursos humanos para saúde, fixando as diretrizes para sua execução. 
Os estados, territórios e o Distrito Federal teriam como atribuições o planejamento integrado de saúde, criação e operação de serviços de saúde em apoio às atividades municipais. Enquanto aos municípios caberia a manutenção de serviços de saúde, especialmente os de pronto-socorro (sic); vigilância epidemiológica. A função do setor privado foi referida como de "prestação de serviços de saúde as pessoas" sobretudo mediante contratos com a previdência social e sob sua fiscalização.

A despeito de suas limitações, a chamada Lei do SNS pode ser reconhecida como um passo adiante. Não só por se tratar da primeira tentativa concreta para racionalizar o sistema, dentro dos limites permitidos no contexto político então vigente, como por representar o reconhecimento oficial de algumas das imperfeições na organização do sistema há muito apontadas por estudiosos do setor.

Na Assembléia da Organização Mundial de Saúde (OMS) realizada em 1975, Halfdan Mahler, seu diretor geral, afirmou: "para vencer a dramática falta de médicos no mundo inteiro é indispensável aproveitar todo o pessoal disponível, as parteiras curiosas, o pessoal de nível elementar e até mesmo os curandeiros". 0 pronunciamento da OMS vinha a encontro do que, na época, era consensual e corrente entre parte significativa de formadores de opinião nacionais no setor saúde: a única possibilidade de levar a assistência médico-sanitária a todos dos que dela carecem é através da utilização de técnicas simples e de baixo custo, aplicáveis sem dificuldade ou risco, por pessoal de nível elementar recrutado na própria comunidade e remunerado de acordo com os padrões locais.

0 Programa de Interiorização de Ações de Saúde e Saneamento (Puss), aprovado pelo o Decreto $\mathrm{n}^{0} 76.307$ de $24 / 8 / 1976$, foi criado com linhas de ação ajustadas a esse propósito. 0 Programa reconhecia que a complexidade nosológica de uma comunidade aumenta na medida em que cresce o seu grau de desenvolvimento. Essa circunstância recomenda que os serviços de saúde sejam organizados de forma hierarquizada, descentra- 
lizando - para unidades mais simples localizadas na periferia - as ações de saúde de maior frequiência e de fácil aplicação, mas centralizando - em locais estratégicos - os recursos e serviços especializados ou de maior porte.

0 objeto central do Programa era dotar as comunidades do Nordeste - cidades, vilas e povoados até 20 mil habitantes - de uma estrutura básica e permanente de saúde pública capaz de contribuir na solução dos problemas médico-sanitários de maior reflexo social. A rede de serviços, fundamentalmente estadual e municipal, se desdobrava em três níveis de atuação: elementar, intermediário e de apoio. Os dois primeiros estavam constituídos por unidades operadas por pessoal de nível elementar. As unidades de apoio, estrategicamente localizadas, estavam formadas por unidades integradas de saúde, dispondo de recursos humanos de nível profissional e, em alguns casos, de facilidades para hospitalização.

Tão importante quanto o financiamento destinado aos diversos projetos que compunham o PIASs, parte dele oriundo do FAS, operado pela Caixa Econômica Federal (CEF), eram a previsão do remanejamento dos recursos e a reorientação doutrinária, determinadas para as atividades desenvolvidas pelo INPS e, sobretudo, pelo Funrural na região. A contribuição da previdência social foi considerada indispensável para viabilizar o custeio do programa depois de sua fase de implantação. A participação do MPAS no custeio da rede, sob o respaldo formal da Lei $n^{0} 6229$, que lhe atribuía competência, dentro do Sistema Nacional de Saúde, para experimentar "novas modalidades de prestação de serviço de assistência, avaliando sua melhor adequação as necessidades do país", representava uma revisão tática da previdência social visando a acelerar a universalização de suas prestações.

Inicialmente restrito ao Nordeste, o Programa foi estendido às demais regiões a partir de 1979, marcando, desde seu começo, um ponto importante de inflexão na forma de atuação da previdência. Até então atuando, de forma direta, por intermédio de sua rede própria concentrada nos centros de maior porte e, indiretamente, mediante contratos com a rede 
privada, o INPS, com o PIAss, expande sua atuação indireta formalizada pelos convênios com as secretarias de Saúde dos governos subnacionais. Essa forma de parceria com instância subnacional só tinha acontecido antes no Distrito Federal, a partir da criação de Brasilia em 1960.

No final dos anos 1970 e no início da década seguinte, repercutiam sobre o setor saúde os primeiros movimentos da transição democrática e a profunda crise econômica do país, com especial repercussão no financiamento do Estado. Com a abertura política - "lenta, gradual e segura" - para usar a expressão cunhada na época (governo Ernesto Geisel) - emergem novos atores e movimentos sociais. Reivindicações por serviços e ações de saúde passam a integrar com mais destaque a pauta de demandas.

A crise econômica teve duplo efeito. Por um lado, agravou a distribuição da renda e a qualidade de vida da população, o que aumentou as necessidades de atenção à saúde; por outro, diminuiu as receitas fiscais e as contribuições sociais, com impacto sobre o volume de recursos destinados à saúde. Nesse cenário, consolidou-se no país o movimento pela Reforma Sanitária, cujas principais bandeiras eram: 1) a melhoria das condições de saúde da população; 2) o reconhecimento da saúde como direito social universal; 3) a responsabilidade estatal na provisão das condições de acesso a esse direito; 4) a reorientação do modelo de atenção, sob a égide dos princípios da integralidade da atenção e da equidade; 5) a reorganização do sistema com a descentralização da responsabilidade pela provisão de ações e serviços.

A construção de sólida aliança política em torno dessas teses foram legitimadas, em 1986, na VIII Conferência Nacional de Saúde (CNS). As sete primeiras conferências haviam sido eventos técnicos, com presença seletiva de especialistas, em sua maioria vinculados ao Ministério da Saúde e à problemática sanitária de responsabilidade dessa agência. A VIII CNS não só ampliou a participação de outros segmentos técnicos, sobretudo da previdência social, como incluiu ampla representação de usuários dos serviços de saúde. 
A década de 1980, em particular a sua primeira metade, foi bastante fértil para o processo de articulação intra-setorial, configurando o que se pode chamar de 'fase das estratégias racionalizadoras'. Foram iniciativas importantes do período:

- criação, em 1980, da Comissão Interinstitucional de Planejamento (CIPLAN), cuja principal função era fixar os repasses federais dos dois ministérios (Saúde e Previdência Social) para o financiamento de serviços prestados pelas redes estaduais e municipais, além de estabelecer normas de articulação programática entre Ministério da Saúde, Previdência e Educação (hospitais universitários e de ensino);

- instituição, em 1982, do Plano de Reorientação da Assistência à Saúde no âmbito da Previdência Social, mais conhecido como Plano do Conasp, que seguia diretrizes como a prioridade para a atenção primária, a integração das diferentes agências públicas de saúde em um sistema regionalizado e hierarquizado e a diminuição da capacidade ociosa do setor público. 0 Plano Conasp, elaborado em 1982, propôs - como forma de controlar os gastos com saúde e, simultaneamente, viabilizar a expansão da cobertura - a reversão do modelo centrado na assistência hospitalar, a eliminação da capacidade ociosa do setor público e a melhoria da operação da rede, através do aumento da produtividade, da racionalização e da qualidade dos serviços.

Integrando, mediante convênios, os sistemas públicos estaduais e municipais à prestação de serviços de saúde, o Plano, mesmo sem ter sido implementado integralmente, criou as bases para novas políticas públicas de expansão de cobertura nos anos seguintes, quais sejam:

- implantação, em 1984, das Ações Integradas de Saúde (AIS), que reforçou a atuação da Ciplan na área federal, e estimulou a criação de Comissões Interinstitucionais de Saúde, no âmbito dos estados, das regionais estaduais de saúde e dos municípios. Como decorrência desse esforço de articulação e coordenação da ação pública na área da saúde, até o final de 1987, 2.500 municípios já eram signatários do convênio das AIS; 
- início do Programa de Desenvolvimento de Sistemas Unificados e Descentralizados de Saúde nos Estados (Subs), em 1987. Esse programa, como as AIS, enfatizava os mecanismos de programação e orçamentação integradas e as decisões colegiadas tomadas no âmbito das Comissões Interinstitucionais. Avançando no sentido da descentralização da gestão do sistema, tinha como foco as secretarias estaduais de saúde, que deveriam assumir as responsabilidades de órgãos reitores dos sistemas estaduais de saúde. Uma antecipação, em certa medida, do modelo posteriormente adotado pelo SUS com a Comissão Interinstitucional Tripartite e as Comissões Bipartites.

Ao lado desse quadro político-institucional, crescia, a partir de 1985, um amplo movimento político setorial que teve, como pontos culminantes, a realização da VIII CNS (1986), os trabalhos técnicos desenvolvidos pela Comissão Nacional de Reforma Sanitária (CNRS), criada pelo Ministério da Saúde, em atendimento a proposta da VIII CNS, e o projeto legislativo de elaboração da Carta Constitucional de 1988.

0 reconhecimento da saúde como direito inerente à cidadania, o conseqüiente dever do Estado na promoção desse direito, a instituição de um sistema único de saúde, tendo como princípios a universalidade e integralidade da atenção, a descentralização, com comando único em cada esfera de governo, como forma de organização e a participação popular como instrumento de controle social, foram teses defendidas na VIII CNS e na CNRS que se incorporaram ao novo texto constitucional.

\section{Sistema Único de Saúde}

\section{Marco normativo}

0 conceito de seguridade social - "um conjunto integrado de ações de iniciativa dos poderes públicos e da sociedade, destinados a assegurar os direitos relativos à saúde, à previdência e à assistência social" (CF, art. 194) - 
constitui uma das mais importantes inovações incorporadas à Constituição promulgada em 5 de outubro de 1988. O novo conceito impôs uma transformação radical no sistema de saúde brasileiro. Primeiro, reconhecendo a saúde como direito social; segundo, definindo um novo paradigma para a ação do Estado na área. Esse novo marco referencial está expresso em dois dispositivos constitucionais:

- Art. 196 - o direito à saúde deverá ser garantido "mediante políticas econômicas e sociais que visem à redução do risco de doença e de outros agravos e ao acesso universal e igualitário às ações e serviços para sua promoção, proteção e recuperação", reconhecendo, por conseguinte, a múltipla determinação e a estreita relação da saúde com o modelo de desenvolvimento;

- Art. 198 - as ações e serviços públicos de saúde serão organizados em uma rede regionalizada e hierarquizada, constituindo um sistema único de saúde, de acordo com as seguintes diretrizes: 1) o atendimento integral, com prioridade para as atividades preventivas, sem prejuízo dos serviços assistenciais; 2) a descentralização com direção única em cada esfera de governo e 3) a participação comunitária.

Ao detalhar os princípios e diretrizes sob os quais o sistema passou a ser organizado e as competências e atribuições das três esferas de governo, a regulamentação (Leis $\mathrm{n}^{0} 8080$, de 19/9/1990, e $\mathrm{n}^{0}$ 8142, de 28/12/1990), buscou delinear o modelo de atenção e demarcar as linhas gerais para a redistribuição de funções entre os entes federados. 0 SUS foi definido como constituído pelo conjunto de ações e serviços de saúde, prestados por órgãos e instituições públicas, federais, estaduais e municipais, da administração direta $\mathrm{e}$ indireta $\mathrm{e}$ das fundações mantidas pelo poder público (Lei $\mathrm{n}^{\circ}$ 8080, art. $4^{2}$, caput $)$. A iniciativa privada pode participar do SUS em caráter complementar (CF, art. 199, § 1ㅜㅜ Lei $n^{\circ} 8080$, art. $4^{\ell}, \S 2^{\circ}$ ), mediante contrato de direito público, mas as entidades filantrópicas e as sem fins lucrativos terão preferência (CF, art. $199, \S 1^{\varrho}$, Lei 8080 , art. 25). 
Os contornos do novo modelo de atenção estão configurados nos princípios constitucionais da universalidade, eqüidade e integralidade da assistência. Tais elementos de natureza doutrinária apontam a construção de um sistema de saúde que reverta a lógica de provisão de ações e serviços, reorientando a tendência hegemônica da assistência médico-hospitalar, predominante no modelo anterior, e substituindo-a por um modelo de atenção orientado para a vigilância à saúde.

Consolidando o processo de evolução do sistema público de saúde, a Constituição Federal de 1988 consagrou o acesso universal e igualitário aos serviços de saúde como um direito de cidadania (CF, art. 196). Sua regulamentação (Lei 8080/1990) inclui, entre os princípios do então criado SUS, a "igualdade da assistência, sem preconceitos ou privilégios de qualquer espécie" (art. $7^{\circ}$, inciso IV). A Lei (art. 43) ainda garantiu a gratuidade da atenção de modo a impedir que 0 acesso fosse dificultado por uma barreira econômica além das já existentes, como a distância dos serviços, o tempo de espera, o horário de funcionamento, a expectativa negativa quanto ao acolhimento, além de fatores educacionais e culturais.

Uma análise geral da Lei $\mathrm{n}^{0} 8080$ é suficiente para detectar as suas principais tendências: realce das competências do Ministério da Saúde, restringindo-lhe a prestação direta dos serviços apenas em caráter supletivo; ênfase na descentralização das ações e serviços para os municípios; e valorização da cooperação técnica entre Ministério da Saúde, estados e municípios, onde estes ainda eram vistos, preponderantemente, como receptores de tecnologia.

0 Ministério da Saúde é o grande responsável pela estratégia nacional do SUS, seu planejamento, controle, avaliação e auditoria, bem como pela promoção da sua descentralização. Ao Ministério também cabem a definição e a coordenação dos serviços assistenciais de alta complexidade, redes nacionais de laboratórios, de sangue e hemoderivados em nível nacional. Uma terceira missão exclusiva do poder central é a regulação do setor 
privado, mediante a elaboração de normas, critérios e valores para remuneração dos serviços, bem como de parâmetros de cobertura assistencial.

A Secretaria de Estado está encarregada de planejar, programar e organizar uma rede regionalizada e hierarquizada de serviços, cujo funcionamento deve acompanhar, controlar e avaliar. Portanto, ao Estado também cabe coordenar os serviços assistenciais de alta complexidade, laboratórios de saúde pública e hemocentros sob a sua responsabilidade. No entanto, a Lei Orgânica da Saúde (LoAs) não faz referência a um papel estratégico do Estado, similar ao definido para o nível federal. Igualmente, não está prevista uma atuação reguladora dos serviços privados de saúde.

É evidente que o modelo original do SUS concede protagonismo ao município. À Secretaria Municipal, além, naturalmente, da gestão e execução das ações e serviços públicos de saúde, são confiados o seu planejamento, organização, controle e avaliação, inclusive a gestão dos laboratórios públicos de saúde e dos hemocentros. 0 poder municipal também é exercido na celebração de contratos e convênios, controle, avaliação e fiscalização das atividades de" iniciativa privada.

A inclusão da participação da comunidade como umas diretrizes para a organização do sistema público de saúde foi umas mais importantes inovações introduzidas pela Assembléia Nacional Constituinte em 1988 (CF, art. 198, III), propiciando a criação de diversos mecanismos de articulação entre esferas de governo e de participação e controle social sobre as políticas públicas.

$\mathrm{Na}$ área da saúde, tais mecanismos são de duas naturezas. Uma se refere aos fóruns exclusivos de representantes das instâncias subnacionais de governo, 'beneficiárias', por assim dizer, da descentralização. Isto é, estados e municípios, para os quais o processo descentralizador, em tese, transfere poder retirado do nível central. Os dois fóruns de participação e articulação, neste caso, são: 1) o Conselho Nacional de Secretários Estaduais de Saúde (Conass), criado em 1980 e que reúne os secretários de Saúde dos 26 
estados e do Distrito Federal, e 2) o Conselho Nacional de Secretários Municipais de Saúde (Conasems), instituído em 1988 e ao qual estão filiados secretários de cerca de $90 \%$ dos municípios.

Esses dois colegiados, criados antes da nova Constituição, tiveram atuação destacada no processo constituinte. Embora, eventualmente, tenham interesses políticos não coincidentes, já que representam diferentes esferas de poder, constituem elementos fundamentais na articulação entre instâncias de governo tanto no âmbito estadual (Comissões Bipartites) como no federal (Comisssão Tripartite).

A segunda natureza se refere aos colegiados que funcionam como mecanismos de participação popular para o controle social. Coerente com 0 processo adotado para sua formulação, a nova Constituição instituiu mecanismos e diretrizes que asseguram a participação social. É o caso da iniciativa popular na proposição de leis (CF, art. $61, \S 2^{2}$ ) e, especificamente no campo da saúde, como já referido, a inclusão, entre as diretrizes para a organização do sistema único de saúde (CF, art. 198), da "descentralização" (CF, art. 198, I) e da "participação da comunidade" (CF, art. 198, III).

Os fóruns setoriais para participação popular no desenho e gestão de políticas públicas têm como fundamento tais dispositivos constitucionais. $\mathrm{Na}$ área da saúde, esses instrumentos de participação são os Conselhos e as Conferências nacionais, estaduais e municipais de Saúde. Nesses colegiados, a sociedade civil tem presença significativa. Nos Conselhos e Conferências de Saúde, os representantes dos usuários ocupam metade dos postos, a outra metade é formada pela representação dos provedores de serviços (governo, profissionais de saúde e setor médico-hospitalar privado).

A criação desses colegiados na saúde fez progressos a partir da Lei $\mathrm{n}^{0} \mathbf{8 1 4 2 / 9 0}$ que a regulamentou. Em menos de seis anos foram instalados conselhos de saúde na área federal em todos os estados e em 3.031 municípios (55\% do total). Atualmente, quase todas as municipalidades contam com esse tipo de órgão colegiado. 
A CNS, por sua vez, reunindo milhares de delegados, é precedida de fóruns similares estaduais e municipais. A partir da VIII CNS, realizada em 1986, e que contou com a participação de representantes de vários segmentos sociais, as conferências têm sido convocadas regularmente a cada quatro anos para avaliar a situação de saúde e oferecer diretrizes para a formulação da política setorial. A XI CNS foi realizada em Brasília em dezembro de 2000.

Logo no início dos anos 1990, as relações internas ao SUS passaram a ser subordinadas por normas técnicas publicadas em Portarias Ministeriais. As Normas Operacionais Básicas, conhecidas como NOBs, e editadas entre os anos de 1991 e 1996, foram o referencial dessa regulação, fixando as bases de funcionamento do Sistema, a saber:

- pagamento por produção de serviços para órgãos de governo, mediante a apresentação de faturas (esse procedimento, até então comum para com prestadores de serviços privados, agora era estendido aos prestadores públicos);

- definição dos critérios para alocação de recursos, condicionando a sua liberação à apresentação de planos, programas e projetos;

- criação de mecanismos de decisão com eminente caráter participativo e descentralizador.

Em princípios de 1998, o paradigma de transferências de recursos foi redefinido. Em substituição ao pagamento de serviços por comprovação de faturas, os repasses seriam determinados com anterioridade e realizados sob a responsabilidade do Fundo Nacional de Saúde (FNS), diretamente para os Fundos Municipais. A grande novidade era 0 estabelecimento de um valor per capita mínimo, base de cálculo do produto orçamentário destinado ao município. Finalmente, com a criação do Piso Assistencial Básico (PAB) e a sua transferência regular e automática, o Ministério da Saúde assegurava ao município um montante fixo mensal para a execução de serviços essenciais, individuais e coleti- 
vos, de promoção e assistência à saúde e bem-estar da sua população atendimento básico, vacinação, assistência pré-natal, pequenas cirurgias em ambulatórios etc.

A garantia de efetividade do PAB apoiava-se no comprometimento do gestor em adequar o seu programa de governo aos recursos orçados. Estava a se implementar, portanto, uma nova filosofia de gestão em saúde que priorizava a integração entre planejamento e ação; e a definição clara da responsabilidade da autoridade sanitária e corpo técnico-administrativo locais pelo sucesso da política nacional de saúde.

Mas 0 grande mérito do pioneirismo é justamente a coragem de fazer do ideal uma realidade, mesmo às custas dos erros e acertos de experiências inéditas. A proposta do PAB também encontrou suas limitações que logo se fizeram sentir.

A definição a priori de uma unidade de valor nacional, por exemplo, era incapaz de abarcar todas as realidades de um país tão diverso e distante em si, nos seus contextos regionais. A fixação do quantitativo de $\mathbf{R} \$ 10,00$ por habitante resultava em montantes inadequados às necessidades de muitos municípios, que acabavam sendo contemplados com mais ou com menos recursos que os necessários ao desempenho mínimo das suas funções.

Exemplo significativo dos problemas causados por essa distorção foi identificado na execução do Programa de Saúde da Família (PSF), uma ação estratégica fundamental do SUS. A concepção estrutural e dinâmica do PSF previa a construção de uma rede de cobertura populacional crescente. A reserva de um percentual fixo do PAB para as suas atividades, portanto, não só era inadequada como impedia a rápida expansão e sustentabilidade do PSF, especialmente nos municípios pequenos.

Outros programas sequer eram considerados pelo $\mathrm{PAB}$, que restringia seus recursos para a assistência à saúde em detrimento das ações de promoção e preventivas. Estas continuavam a depender da assinatura de convênios para a sua liberação, à mercê de uma burocracia mais propensa a exigências do que à eficiência. 
O Ministério da Saúde concluiu que deveria redefinir o PAB, rebatizando-o com o nome de Piso de Atenção Básica. Mais do que a simples troca de palavras, imprimia-se um novo conceito e objetivo ao Piso: a Atenção não só às ações de assistência, mas também às de prevenção e promoção, garantindo a extensão dos benefícios ao conjunto da atenção primária à saúde. Após meses de negociações entre os gestores dos diferentes níveis de governo, decidiu-se pela partilha do PAB em dois componentes distintos: o PAB Fixo, que manteria um valor per capita nacional; e o PAB Variável, destinado aos programas prioritários da iniciativa federal.

A idéia de um PAB Variável tinha por objetivo garantir 0 atendimento de programas estratégicos, ampliando a 'cesta' de serviços. Agora, também receberiam seus recursos os parceiros mais próximos do PSF, o Programa de Agentes Comunitários de Saúde, o Programa de Combate às Carências Nutricionais, o Programa de Assistência Farmacêutica Básica, o Programa de Ações Básicas de Vigilância Sanitária, o Programa de Ações de Epidemiologia e Controle de Doenças. A introdução de cada um desses programas, entretanto, estaria condicionada a regras, formas de financiamento e normas de adesão específicas.

Anteriormente ao advento do $\mathrm{PAB}, 582$ municípios não contavam com qualquer recurso federal para cobrir despesas com a atenção básica à saúde da sua população. Apenas 1.842 - 40,4 milhões de pessoas - recebiam do governo Federal, mediante a apresentação de faturas, valores médios que variavam de $\mathrm{R} \$ 0,00$ a $\mathbf{R} \$ 5,00$ per capita anual. Em 1997, um ano após o advento do Piso de Atenção Básica, o volume total dos recursos ultrapassaria $\mathbf{R} \$ 1,2$ bilhão. No final de dezembro de 2001, a reserva para 0 seu repasse já era de mais de $\mathbf{R} \$ 1,7$ bilhão, um aumento tão expressivo que fez da Atenção Básica à Saúde no Brasil uma prioridade indiscutível.

0 PAB trouxe estabilidade ao Sistema, mas o seu impacto não foi imediato, senão progressivo e surpreendente: em 1996, apenas 114 municípios eram diretamente responsáveis pelo gerenciamento dos seus recursos; 
em 1998, 1.343 já haviam sido habilitados. Em dezembro de 2001, nada menos que 5.516 - quase a totalidade dos municípios brasileiros, uma população de 172,1 milhões de pessoas - eram beneficiados com $R \$ 10,00$ por habitante/ano em transferências diretas Fundo a Fundo (ou seja, do Fundo Nacional de Saúde para os fundos municipais).

A Portaria GM/MS $\mathrm{n}^{2} 1399$, de 15 de dezembro de 1999 , regulamentou a NOB/96, no que se refere às competências da União, estados, municípios e Distrito Federal na área de epidemiologia e controle de doenças. No ano 2000, o Ministério da Saúde, por intermédio da Fundação Nacional de Saúde, iniciou a implementação do processo de descentralização nessa área. E assim, a partir de junho de 2001, o volume de recursos transferidos Fundo a Fundo para estados e municípios passa a ser subdividido em quatro itens principais:

- Recursos para a Atenção Básica (PAB Fixo e PAB Variável);

- Recursos para a Vigilância Epidemiológica e Controle de Doenças;

- Recursos para a Assistência de Média Complexidade;

- Recursos para a Assistência de Alta Complexidade.

0 período de implementação da NOB/96, compreendido, grosso modo, entre 1998 e 2000 (as habilitações de municípios, no ano de 2001, foram residuais), foi marcado por uma série de avanços na descentralização do SUS. 0 adiantamento de recursos e sua remessa automática, ao exigir objetivos claros e critérios estritos na definição dos itens de despesa, permitiram uma programação mais realista e segura das ações pelo gestor local, reforçando o seu papel planejador. A programação antecipada pelo nível federal também reduziu os prejuízos decorrentes de possíveis contingências orçamentárias.

A implementação do PAB constituiu um verdadeiro divisor de águas no processo de descentralização do Sistema. Da mesma forma, foram estrategicamente fundamentais a expansão das Equipes de Saúde da Família e a ação mobilizadora dos Agentes Comunitários de Saúde, além, natural- 
mente, de experiências isoladas, no âmbito local e regional, seja na área de atenção básica, seja na organização de redes de referência em várịos municípios e estados.

No plano da gestão, milhares de municípios integraram-se voluntariamente às NOBs e às suas condições, mediante ampla negociação das transferências de responsabilidades, atribuições e recursos.

As NOBs, portanto, foram o principal instrumento legal para a descentralização das ações de saúde, particularmente as de atenção básica. 0 mesmo, entretanto, não se podia dizer dos serviços de maior complexidade. Faltava, ainda, uma abordagem regionalizada e mais adequada à estrutura administrativa do país e suas particularidades.

Como exemplo, eis uma constatação bastante comum a essa realidade. É comum, entre os municípios habilitados em Gestão Plena e capacitados a oferecer serviços de maior complexidade, tentar impedir 0 acesso a esse atendimento pelos moradores de cidades vizinhas, sob a argumentação de que os recursos que recebem já estão comprometidos com a assistência aos seus habitantes. Sem outra saída, os municípios menores, ressentidos com as dificuldades dessa falta de autonomia no atendimento à sua população, são obrigados a expandir tais serviços sem uma escala de demanda que justifique o seu investimento, gerando 'deseconomia' na aplicação dos já limitados recursos.

Diante disso, era necessário pensar uma política de incentivos que concebesse o município, sua experiência e tradição na oferta de serviços de assistência à saúde de complexidade e alcance regional. Uma política que superasse o viés da atomização na municipalização dos recursos, ampliando a cobertura das ações e serviços mais além dos limites do município, com economia de despesas e ganho de qualidade para a saúde. Foi quando, em janeiro de 2001, o Ministério da Saúde, apoiado pela Comissão Intergestores Tripartite, tomou a decisão de instituir as Normas de Assistência à Saúde (NoAs) em substituição às NOBs. 
Ao longo de todo o ano 2000, o Ministério da Saúde coordenou um intenso processo de debate e negociação com as representações nacionais dos secretários de estado (Conass) e municipais (Conasems) de saúde, no âmbito da Comissão Intergestores Tripartite (CIT) e do Conselho Nacional de Saúde (CNS), com o propósito de aperfeiçoar e consolidar a descentralização do SUS.

A publicação da Norma Operacional de Assistência à Saúde (NoasSUS $01 / 2001$, em janeiro de 2001, foi resultado desse longo processo de negociação e teve como objetivo central "promover maior eqüidade na alocação de recursos e no acesso da população às ações e serviços de saúde em todos os níveis de atenção". Para alcançá-lo, instituiu a regionalização como macroestratégia fundamental naquele momento, a partir da articulação de três linhas de ação.

Um dos pontos mais importantes da NoAs diz respeito ao processo de elaboração do Plano Diretor de Regionalização. Coordenado pelo gestor estadual e com a participação do conjunto de municípios, esse Plano deve contemplar:

1) a divisão do território estadual em regiões/microrregiões de saúde, definidas segundo critérios sanitários, epidemiológicos, geográficos, sociais, de oferta de serviços e de acessibilidade;

2) diagnóstico dos principais problemas de saúde e das prioridades de intervenção;

3) a constituição de módulos assistenciais resolutivos, formados por um ou mais municípios, assegurando o primeiro nível da média complexidade e 0 apoio necessário às ações de atenção básica;

4) os fluxos de referência para todos os níveis de complexidade e os mecanismos de relacionamento intermunicipal;

5) a organização de redes assistenciais específicas;

6) Plano Diretor de Investimentos, que procura suprir as lacunas assistenciais identificadas de acordo com as prioridades de intervenção. 
A NoAs prevê a organização de uma assistência qualificada e de melhor resolutividade na atenção básica, a partir da identificação de áreas estratégicas essenciais, relacionadas a problemas de saúde de abrangência nacional - saúde da mulher, saúde da criança, saúde bucal, controle da hipertensão e diabetes, controle da tuberculose e eliminação da hanseníase. Complementarmente, os gestores estaduais e municipais podem definir outras áreas de ação, de acordo com as especificidades locais.

Além de assegurar a atenção básica em todos os municípios brasileiros, a NoAs propõe a formação de módulos assistenciais resolutivos, formados por um ou mais municípios, que garantam, no âmbito microrregional, o acesso ágil e oportuno de todos os cidadãos a um conjunto de procedimentos de saúde necessários para 0 atendimento de problemas mais comuns, nem sempre oferecidos em municípios menos populosos. A qualificação de regiões/microrregiões na assistência à saúde justifica-se pela tentativa de garantir 0 acesso a ações resolutivas mais além dos limites municipais, com ganho de qualidade e economia.

Também foram estabelecidas as diretrizes gerais de organização das demais ações de média e alta complexidade, por meio do mapeamento das redes de referência em áreas estratégias específicas como gestação de alto risco, urgência e emergência, hemoterapia, entre outras. Esse tipo de regionalização requer uma articulação dos gestores municipais sob coordenação e regulação estadual, para a negociação e pactuação de referências intermunicipais e sua Programação Pactuada e Integrada (PPI). Além disso, é necessário o fortalecimento da capacidade gestora de estados e municípios sob uma nova perspectiva reguladora, de controle e avaliação do Sistema.

Do ponto de vista do financiamento, as Noas significaram um novo incentivo do nível federal. 0 PAB Fixo foi ampliado para a cobertura de procedimentos do primeiro nível da média complexidade ambulatorial, com base em um valor per capita nacional. Essa inovação é muito importante, pois assinala uma tendência de superação da lógica anterior de financiamento, fortemente orienta- 
da pela oferta preexistente de serviços. 0 mecanismo de pré-pagamento implica um perfil mais efetivo do gestor no planejamento dos serviços, de acordo com as necessidades e prioridades de saúde da população.

Logo em seguida à publicação da NoAs, em janeiro de 2001, o Ministério da Saúde passou a acompanhar e oferecer apoio sistemático aos processos de regionalização, desenvolvendo estratégias e instrumentos de gestão e organização da assistência à saúde em cada um dos estados. Foi observado grande dinamismo na articulação entre gestores estaduais e municipais para a elaboração dos seus planos diretores de regionalização, investimentos e Programação Pactuada e Integrada. Tanto é assim que todos os estados já esboçaram seus Planos Diretores e, na sua maior parte, já vêm adotando medidas significativas para a organização da rede de serviços visando à sua melhoria e amplo acesso à população.

A evolução do processo de implantação do SUS, vista sob a ótica de alguns indicadores de descentralização, possibilita conclusões contraditórias. Uma é otimista; a outra, nem tanto. Segundo a primeira, dez anos depois (1999) do início efetivo (1990) do processo de implementação do SUS, 96,4\% dos municípios, correspondendo a $92 \%$ da população brasileira, estavam habilitados a uma das duas formas de gestão vigentes na época - Gestão Plena da Atenção Básica (GPAB) e Gestão Plena do Sistema Municipal (GPSM).

Para os mais exigentes, estes valores ainda não seriam satisfatórios. Em primeiro lugar, porque o processo de adesão à forma mais avançada de gestão (GPSM) alcançava apenas 491 municípios $(8,9 \%)$ em um total de 5.506 , embora correspondendo a quase $40 \%$ da população brasileira. A variação inter-regional desses valores é significativa e parece não ter correlação com o grau de desenvolvimento da região. 0 percentual de municípios habilitados na GPSM varia de 3,6\% na região Sul a $15,8 \%$ no Sudeste.

Em segundo lugar, porque o fato de o município estar enquadrado na Gestão Plena Atenção Municipal, quando se torna o gestor local do SUS, não significa, necessariamente, que tenha assumido todas as prerrogativas e obriga- 
ções inerentes a essa responsabilidade. Estudo do Ministério da Saúde em 16 municípios sob GPSM, em sua maioria capitais, mostrou que o percentual de municipalização da rede ambulatorial pública era de $65,5 \%$. Para um sistema descentralizado, ainda é alto o gasto direto do Ministério da Saúde com serviços de natureza local ou estadual. A despesa do Ministério com a própria rede hospitalar ( $\mathrm{R} \$ 1.222$ milhão) e com pagamento direto a provedores privados R $\$ 5.003$ milhões correspondeu, em 1999, a cerca de 30\% do gasto bruto do Ministério. As transferências de recursos chamadas Fundo a Fundo (R\$ 5.901 milhões), no mesmo ano, tiveram seu uso definido de origem, deixando pouco ou nenhum espaço para prioridades locais até porque, via de regra, essas transferências não cobrem o custo total das ações para as quais se destinam.

\section{PSF como estratégia de mudança do modelo assistencial}

o Programa de Saúde da Familia (PSF) tem sido a principal estratégia governamental para reorientação do modelo assistencial, atingindo a 50 milhões de pessoas, em sua quase totalidade pertencentes às camadas mais carentes. Reconhecida como sendo a política pública de maior potencial para alcançar - com custos suportáveis - a universalização do acesso à atenção integral, o PSF tem seus próprios desafios, afora a (inevitável, por definição) limitação dos recursos financeiros, entre os quais:

1) a concentração da oferta de humanos para a saúde nos centros urbanos e, nestes, nos de maior nível de renda;

2) a integração das equipes de Saúde da Família nas Unidades Básicas de Saúde e a implantação de mecanismos efetivos de articulação (referência contra referência de pacientes) entre estas unidades e os níveis secundário e terciário de atenção;

3) a inadequação do ensino médico às necessidades predominantes na população. 
Quanto a este último ponto, convém observar que o insumo crítico para o PSF é o médico generalista, ou seja, aquele profissional capaz de prevenir, identificar e tratar precocemente as doenças de maior prevalência, as quais - se deixadas ao seu livre curso - desaguariam, em sua maioria, no hospital especializado ou nos serviços de emergências. Este programa vem se constituindo em nicho de mercado, no setor público, em que se registra 0 maior crescimento da demanda por essa categoria de recursos humanos. Sem isto dificilmente será possível modificar o modelo assistencial. E sem mudar o modelo será difícil, para dizer o mínimo, conciliar universalização com atendimento integral.

A mudança do modelo está diretamente relacionada também ao problema da desumanização do atendimento prestado, nas diferentes modalidades assistenciais, em instituições públicas ou privadas, ainda que com características e intensidades distintas. A questão tem múltiplas raízes, entre as quais a própria ineficiência do modelo de atenção vigente, a formação do profissional, as condições de trabalho e a qualidade da gestão dos serviços. A empatia que se estabelece entre usuários e equipe do PSF, dada a frequiência e a natureza dos contatos, favorece amplamente a relação médico-paciente. De qualquer forma, este é um aspecto do atendimento, que, por ser muito valorizado pelos usuários (com justas razões), deve ser considerado na estratégia de mudança. É particularmente significativo que a questão tenha sido o tema principal da XI CNS, em dezembro de 2000.

Desde os anos 1980, a atenção básica à saúde já era uma prioridade nas intenções e nos discursos preocupados com as questões sociais. Faltava a decisão política dos governantes no sentido da sua concretização em objetivos, programas e metas de ação. Enquanto isso, o Sistema, em crise, cedia espaço ao avanço da chamada medicina suplementar, representada pelos planos e seguros privados de saúde.

As atividades preventivas tinham de competir com as curativas - dos primeiros socorros à assistência de alta complexidade - por escassos recur- 
sos. Nesse contexto adverso, iniciativas inspiradas nos modelos da medicina preventiva tinham pouco espaço para se desenvolver, restritas a ações pontuais e esparsas dos outros níveis de gestão. A importância estratégica do PSF reside na sua vocação para substituir o antigo modelo, predominantemente assistencial, por um conjunto de ações preventivas, terapêuticas e de promoção de uma vida mais saudável e menos dependente do hospital como foco central dos serviços públicos de saúde.

Na sua primeira fase, a principal preocupação do Programa era com a ampliação da sua cobertura às comunidades desprovidas de assistência. Posteriormente, o PSF se afirmou como cerne de uma mudança radical no modelo vigente de atenção básica. Desde então, tem sido considerada fundamental a sua implantação nas médias e grandes cidades, bem como nas regiões metropolitanas.

Criado em 1994, o PSF incorpora e reafirma os princípios básicos do SUS na estrutura da Unidade de Saúde da Família, vinculada à rede de serviços de forma a garantir a atenção integral aos indivíduos e famílias, bem como a assegurar a sua transferência para clínicas e serviços de maior complexidade, sempre que a saúde da pessoa assim exigir. Cada Unidade de Saúde da Família trabalha em um território de abrangência definido, sendo responsável pelo cadastramento e acompanhamento da população adscrita a essa área.

A Equipe de Saúde da Família (ESF) é composta, minimamente, de um médico, um enfermeiro, um auxiliar de enfermagem e quatro a seis agentes comunitários de saúde (ACS). Outros profissionais - a exemplo de dentistas, assistentes sociais e psicólogos - podem ser incorporados ou constituir uma equipe complementar, de acordo com as necessidades e possibilidades locais. Recomenda-se o limite de atendimento a 4.500 pessoas por equipe. A depender da concentração de famílias no território sob a responsabilidade, a Unidade de Saúde da Família atua com uma ou mais equipes de profissionais. 
0 médico atende a todos os integrantes de cada família, independentemente de sexo e idade; com os demais integrantes da equipe, desenvolve ações preventivas e de promoção da qualidade de vida da população. 0 enfermeiro supervisiona o trabalho do ACS e do auxiliar de enfermagem, realiza consultas na unidade de saúde, bem como assiste às pessoas que necessitam de cuidados de enfermagem no domicílio. 0 auxiliar de enfermagem realiza procedimentos de enfermagem na unidade básica de saúde e no domicílio e executa ações de orientação sanitária. Por sua vez, o ACS constitui 0 elo entre os moradores e os serviços de saúde. Se alguém adoece e necessita de atendimento especializado, é encaminhado à unidade de saúde onde será tratado, sempre acompanhado pelo ACS, até a sua completa reabilitação. 0 ACS também é responsável pela orientação do indivíduo e da comunidade na promoção e proteção da sua saúde, ajudando na identificação dos riscos e na mobilização da coletividade pela conquista de ambientes e condições de vida mais saudáveis. Ele ainda tem por dever notificar aos serviços de saúde a ocorrência de doenças que exigem vigilância.

Tabela 1 - Evolução da implantação do PSF/PACs. Brasil - 1998 a 2002

\begin{tabular}{lccc}
\hline Março de 1998 & Maio de 2002 & Variação & Percentual \\
\hline Equipes de Saúde da Família & 1.843 & 15.201 & $+725 \%$ \\
Municípios com PSF implantado & 649 & 3.984 & $+514 \%$ \\
Agentes Comunitários de Saúde & 58.460 & 163.923 & $+180 \%$ \\
\hline
\end{tabular}

Fonte: SAS/MS, 2002.

\section{A saúde mental: um exemplo de mudança do modelo assistencial}

No Brasil, tal como na imensa maioria dos países ocidentais, por mais de século e meio, a atenção aos portadores de transtornos mentais esteve centrada na referência a hospitais psiquiátricos especializados, resultando num modelo excludente e centralizador, em que eram freqüentes a estigmatização, a cronificação e $o$ isolamento desta população. Esta oferta 
hospitalar concentrava-se, evidentemente, nos centros de maior desenvolvimento econômico do país, deixando vastas regiões carentes de qualquer recurso assistencial.

Em 1990, realizou-se a Conferência de Caracas, sob a égide da Organização Pan-Americana (Opas), da qual resultou a Declaração de Caracas. Este documento, do qual o Brasil é signatário, aponta para a substituição do modelo então vigente por outro de base comunitária. A partir das críticas que se vinham acumulando e, notadamente, após a realização desta Conferência, o sistema de saúde brasileiro, em sintonia com as transformações em curso internacionalmente, deu início ao processo de reestruturação de sua assistência psiquiátrica, sob a coordenação do Ministério da Saúde, e com substancial apoio da OPAs, apresentando extraordinário desenvolvimento nesta última década.

Nesse período, criaram-se normas objetivas de qualificação dos serviços de internação psiquiátrica, bem como um dispositivo eficaz de fiscalização dos mesmos, o que permitiu que fosse retirado do sistema, sem acarretar redução da assistência, um grande número de leitos inadequados às exigências mínimas de qualidade assistencial e de respeito aos direitos humanos e de cidadania dos portadores de transtornos mentais.

Concomitantemente, e seguindo-se a lógica de descentralização do SUS, foi sendo estimulada a constituição de redes de atenção psicossocial de base comunitária, substitutivas ao modelo centrado na internação hospitalar, resultando na implantação gradativa de uma rede diversificada de serviços de atenção diária, que já ultrapassam a casa das três centenas em 2002. 
Tabela 2 - A via de mão dupla da Reforma: declínio dos leitos psiquiátricos e ampliação dos serviços de atenção diária (CAPS). Brasil - 1996 a 2002

\begin{tabular}{lrrrrrrc}
\hline Leitos/ CAPS & 1996 & 1997 & 1998 & 1999 & 2000 & 2001 & 2002 (março) \\
Leitos HP & 72.514 & 71.041 & 70.323 & 66.393 & 60.868 & 56.258 & 56.258 \\
CAPS & 154 & 176 & 231 & 237 & 253 & 295 & 312 \\
\hline
\end{tabular}

Fonte: DaTASUSSSAS/MS, 2002.

Em abril de 2001, por ocasião da celebração do Dia Mundial da Saúde, após mais de dez anos de intensos debates, no Congresso e na sociedade civil, foi sancionada pelo presidente da República uma nova e moderna lei de saúde mental (Lei no 10.216, de 6/4/2001). Este documento que dispõe sobre a proteção e os direitos das pessoas portadoras de transtornos mentais e redireciona 0 modelo assistencial em saúde mental, reafirmando o processo de reestruturação da assistência em saúde mental, impondo, ademais, novos desafios à sociedade como um todo e, em particular, aos gestores públicos de saúde, no rumo da construção de um modelo assistencial que se coadune com este novo dispositivo legal.

Em dezembro de 2001, realizou-se a III Conferência Nacional de Saúde Mental, que, tal como as anteriores, resultou em um foro privilegiado para a discussão dos rumos da política nacional de saúde mental, debatendo-se o financiamento das ações de saúde mental, a fiscalização do parque hospitalar psiquiátrico, o ritmo de implantação dos novos serviços extra-hospitalares, a criação de novas estruturas de apoio à desinstitucionalização de pacientes com longo tempo de internação, a formação de recursos humanos para as novas estruturas de atenção em saúde mental, entre outras relevantes questões para a área. Da discussão, resultaram deliberações que têm confluído para a construção de marcos balizadores de uma nova época na saúde mental em nosso país, consoante os fundamentos de justiça e inclusão sociais propugnados pelo SUS.

Nesse período, é fundamental ainda ressaltar o papel crescente de protagonismo ativo que têm desempenhado as associações de usuários de serviços de saúde mental e seus familiares na configuração desta nova rede de assistência e na discussão de seus avatares. 


\section{Recursos do sistema Capacidade instalada}

0 sistema de saúde no Brasil, em sua estrutura e funcionamento institucional, apresenta, de um lado, forte participação do setor privado na assistência hospitalar e, de outro, forte participação do setor público na assistência ambulatorial. As entidades privadas de assistência à saúde também participam de forma complementar ao SUS, dando-se preferência, de acordo com diretriz constitucional, às organizações não lucrativas. Uma investigação realizada, em 1998, pelo Instituto Brasileiro de Opinião Pública (IBOPE), mostrou que 40\% da população utilizava exclusivamente o SUS para seus cuidados de saúde, $44 \%$ utilizava o SUS e outros sistemas e $16 \%$ não era usuária do SUS.

0 setor privado abrange empresas de finalidade lucrativa e instituições comunitárias e filantrópicas: pertenciam a este setor, em 1999, 66,5\% dos 7.806 hospitais, $70,4 \%$ dos 484.945 leitos e $87 \%$ dos 723 hospitais especializados existentes no país. Do mesmo modo, para as funções de apoio a diagnóstico e terapia, $95 \%$ dos 7.318 estabelecimentos eram de natureza privada. Em contraposição, no que se refere a estabelecimentos voltados para a atenção ambulatorial, $73 \%$ dos 41 mil estabelecimentos existentes eram de natureza pública.

A participação privada na oferta de leitos era ainda mais elevada no início da década de 1990 , quando alcançava $75,2 \%$ do total de leitos. Ocorreu desde então uma retração de $10,9 \%$ no número de leitos do setor privado e um crescimento simultâneo de $6,2 \%$ do número de leitos do setor público. Na área do atendimento sem internação, também houve, entre 1992 e 1999, uma retração por parte do setor privado, acarretando uma redução de nada menos que $36,2 \%$ do número de estabelecimentos em atividade. Ainda não foram esclarecidas as causas da diminuição global da participação do setor privado na oferta de serviços de saúde no país, mas, como 
hipótese, podem ser atribuídas a uma redução do poder aquisitivo das camadas de renda média, afetadas pelas sucessivas crises econômicas dos anos 1990, o que pode ter ocorrido simultaneamente com a busca de uma maior eficiência nos processos de gestão adotados por esse setor.

Em 1999, havia, no conjunto dos dois setores, público e privado, 2,9 leitos hospitalares por cada mil habitantes. Essa média nacional, variava entre um máximo de 3,3, na região Centro-0este, muito influenciada pela rede hospitalar da capital, Brasília, e um mínimo de 2,1, na região Norte, de menor densidade demográfica.

No que concerne à oferta de serviços de banco de sangue, os dados disponíveis apontam para uma participação da iniciativa privada em torno de $70 \%$ nos estabelecimentos especializados e, em proporção similar, nos estabelecimentos hospitalares que dispõem de banco de sangue. No entanto, o setor público está dotado de uma bem aparelhada rede de hemocentros, localizada principalmente nas capitais dos estados, que têm a missão de controlar a qualidade dos hemoderivados distribuídos por todo o país.

o SUS reúne um amplo conjunto de instituições gestoras e prestadoras de serviços do setor público de saúde, mantido pelas três esferas de governo, e que é ampliado com a participação do setor privado sob uma relação contratual. Em 1999, 40\% dos 8.769 estabelecimentos privados com internação e $14 \%$ dos 12.891 estabelecimentos privados sem internação mantinham contrato com o setor público. 0 acesso universal por parte da população à atenção integral de saúde - um direito assegurado na Constituição Federal - depende dessa articulação entre prestadores públicos e privados em cada local.

O setor público dispunha, em 1999, de 143.518 leitos, a que se somava uma proporção de leitos no setor privado sob condições de contrato. Deve ser observado que os hospitais privados de maior porte ou mais complexos costumam reservar uma parte reduzida de sua capacidade insta- 
lada para 0 atendimento SUS. Com efeito, pode-se estimar que apenas $23 \%$ das internações no setor privado, em 1999, referiam-se a pacientes vinculados ao SUS.

Como foi observado, o setor público stricto sensu vem promovendo gradualmente a expansão do número de seus leitos hospitalares, o que se faz simultaneamente com uma descentralização da estrutura assistencial para o nível municipal de governo. 0 percentual de leitos em estabelecimentos municipais, em relação ao total de leitos públicos, passou de $26,5 \%$, em 1992, para 43,4\%, em 1999. Ademais, metade das internações nos hospitais públicos em 1999 foi efetuada por estabelecimentos municipais.

A rede ambulatorial do SUS compreendia, em dezembro de 1999, 55.735 estabelecimentos de saúde de diversos tipos. Com 109.708 consultórios e 43.333 consultórios odontológicos; essa oferta corresponde a uma taxa naciọnal média de 6,7 consultórios médicos e 2,6 consultórios odontológicos para cada 10 mil habitantes.

\section{Recursos humanos}

Em 1999, estavam registrados no Brasil, em seus respectivos conselhos profissionais, 273.713 médicos, 98.554 dentistas, 76.613 enfermeiros e 26.427 nutricionistas. A média nacional era de 1,4 médico para cada mil habitantes, havendo fortes contrastes na distribuição entre as cinco regiões do país. As regiões Norte e Nordeste apresentavam taxas reduzidas, de 0,6 e 0,8 médicos por mil habitantes, respectivamente, enquanto a região Sudeste alcançava o índice mais elevado, com dois médicos para cada mil habitantes.

A disponibilidade de recursos humanos pode ser também avaliada através do número de postos de trabalho de cada categoria profissional existentes nos estabelecimentos de saúde, devendo ser notado que esse número geralmente excede o de profissionais registrados, já que um mesmo indivíduo pode ocupar dois ou mais postos de trabalho. Em 1999, os médicos 
detinham 428.808 postos de trabalho, o que representava $65,8 \%$ de todas as categorias de nível superior. Em segundo lugar, estavam os enfermeiros, com 70.175 postos, importando em $10,7 \%$ do total. Os odontólogos apareciam em terceiro lugar, com 52.551 postos de trabalhos, equivalentes a $8 \%$ do total de nível superior. Os farmacêuticos/bioquímicos absorviam 21.119 postos e os fisioterapeutas, 18.720. A forte desproporção entre a disponibilidade de médicos em relação a enfermeiros resulta do fato de que a maior parte do trabalho em enfermagem que é realizado nos estabelecimentos de saúde não está a cargo dos enfermeiros, profissionais com formação universitária, mas, sim, de certas categorias auxiliares de menor escolaridade formal.

Entre 1992 e 1999, o crescimento da oferta de postos de trabalho para enfermeiros foi expressivamente maior do que a oferta de postos para médicos (69,1\% contra $39,6 \%$, respectivamente). Por sua vez, os postos de trabalho de odontólogos cresceram $26,6 \%$, de nutricionistas, $68,2 \%$, e de farmacêuticos/ bioquímicos, $18,8 \%$. No entanto, foram os postos de trabalho associados às funções de reabilitação que tiveram o crescimento mais destacado - cerca de $150 \%$, tanto para os fonoaudiólogos quanto para os fisioterapeutas.

A avaliação da oferta dos principais especialistas em medicina, em 1999, indica que as quatro especialidades básicas (cirurgia, clínica geral, pediatria e gineco-obstetrícia) somavam 262.227 postos de trabalho, abrangendo nada menos que $61 \%$ do total de 429.808 médicos. Foram registrados 23.360 postos de trabalho de anestesistas, 13.678 de radiologistas e 8.716 de psiquiatras. 0 número de postos de residentes de medicina alcançou nesse ano, 17.204 ( $4 \%$ do total). A especialidade incipiente de saúde da família foi registrada pela primeira vez e envolvia declaradamente 3.192 profissionais de medicina. As 'outras especialidades médicas', categoria em que se inserem as especialidades (e subespecialidades) de alta tecnologia, representavam $23,6 \%$ do total de postos de trabalho de médicos.

Numa análise de oportunidades no mercado de trabalho, verifica-se que, dos 429.808 postos de trabalho de médicos, a maior parte 
$(55,2 \%)$ está localizada em estabelecimentos privados e o restante no setor público federal, estadual ou municipal. A participação do setor público no emprego em saúde é maior nas regiões menos desenvolvidas: $53,8 \%$ e $61,9 \%$, nas regiões Norte e Nordeste, respectivamente, e apenas $38,4 \%$ na região Sul.

Em seu conjunto, a proporção de postos de trabalho de médicos no setor público alcançou um pico em 1987 , quando representou $53,5 \%$ do total; diminuiu para $48,1 \%$, em 1992 , e para $44,8 \%$, em 1999 . Tal tendência de decréscimo do emprego público em saúde deixa claro que o setor público de saúde na década de 1990 diminuiu sua capacidade de criação de novos postos de trabalho em relação às duas décadas anteriores, o que pode ser atribuído aos conhecidos problemas de ajuste fiscal do Estado.

No entanto, o crescimento relativo do mercado de trabalho, definido pelo número de profissionais formados pelos cursos de medicina em comparação com o número de novos postos de trabalho de médicos, não parece crítico. No período 1992-1999, houve uma média anual de 7.500 médicos formados, resultando num contingente aproximado de $\mathbf{5 2 . 5 0 0}$ profissionais. Nesse mesmo período, os postos de trabalho de médicos aumentaram em 121.856. Resulta daí uma relação de 2,3 postos de trabalho criados para cada médico formado. Embora esses postos sejam ocupados também por profissionais que já se encontram no mercado de trabalho, essa relação parece indicar, de qualquer modo, que não houve nos anos 1990 um grave problema de desocupação médica no Brasil.

A proporção de postos de trabalho criada na esfera municipal, em comparação com as esferas estadual e federal, pode ser um indicador da política de descentralização do sistema de saúde. Dos postos de trabalho médico pertencentes a estabelecimentos do setor público em 1999, 65,2\% encontravam-se concentrados na esfera municipal. Na região Sul, tal proporção elevava-se a $71,4 \%$. No Norte e Centro-Oeste, predominava ainda um 
padrão relativamente centralista na distribuição desse recurso humano, visto que as esferas federal e estadual, quando somadas, absorviam mais da metade do total de postos disponíveis no sistema público.

A formação de pessoal de nível superior é feita no Brasil por cursos mantidos tanto por instituições públicas quanto privadas, sendo crescente 0 número de cursos pertencentes a instituições privadas de finalidade lucrativa e comunitária/filantrópica. Em 1999, havia 97 cursos de medicina, 153 cursos de enfermagem e obstetrícia e 130 cursos de odontologia. Nos cursos de medicina, a participação pública era mais elevada que a participação privada $(53,6 \%)$, ao passo que em enfermagem era praticamente dividida de forma igual. $\mathrm{Na}$ área de odontologia alcançava $37,7 \%$.

Em 1998, formaram-se 7.616 profissionais em medicina, 5.447 de enfermagem e obstetrícia e 7.710 de odontologia. 0 número mais expressivo de profissionais formados procede da área de psicologia, que tem interface com ciências humanas e ciências da saúde: 11.253 egressos em 1998. Dos 169 cursos existentes nesta área de conhecimento, em 1999, 75,7\% tinham natureza privada. Em farmácia, no ano de 1998, foram formados 5.422 profissionais e, em nutrição, 2.066 profissionais. Cabe destacar a oferta cada vez maior de profissionais nas áreas de 'reabilitação': em fisioterapia graduaram-se 4.202 alunos, nesse ano, e, em fonoaudiologia, 1.797.

A qualidade da produção de pessoal de nível superior vem sendo aferida desde 1996, quando o Ministério da Educação passou a aplicar, aos alunos egressos dos cursos, um exame de avaliação de conhecimentos que, associado a outros elementos de informação, visa a analisar tanto a qualidade quanto a eficiência do ensino em cada área de conhecimento. Estão obrigados a prestar esse exame todos os concluintes do curso como condição necessária para 0 registro do seu diploma. Contudo, o registro não está condicionado ao resultado do exame, o qual funciona, portanto, como um parâmetro de avaliação do curso do qual provém o aluno. De acordo com esses resultados, os cursos obtêm conceitos que variam de $\mathrm{A}$ 
(mais alto) a $\mathrm{E}$, que resultam de cinco faixas de percentis. No ano 2000 , de 81 cursos de medicina avaliados, 11 obtiveram conceito A, 16 obtiveram o conceito C e 33 obtiveram o conceito $D$. De um modo geral, os cursos de instituições públicas tiveram um desempenho notavelmente superior aos cursos de natureza privada.

Embora 0 tema da recertificação tenha sido amplamente debatido nos últimos anos, ainda não se tomou qualquer iniciativa oficial com o objetivo de reavaliar periodicamente 0 desempenho dos profissionais com tal finalidade. Portanto, o registro anual obrigatório nos órgãos de controle do exercício de profissionais da saúde continua a ocorrer sem qualquer exigência de avaliação de desempenho, ao contrário do que ocorre, por exemplo, com os candidatos ao exercício da advocacia que devem se submeter previamente ao exame da $\mathrm{OAB}$. De um modo geral, esses órgãos corporativos vêm manifestando uma preocupação em assegurar o acesso a meios de educação permanente para seus filiados, utilizando, na maioria dos casos, cursos a distância.

Os trabalhadores de nível técnico e auxiliar em funções específicas de saúde são responsáveis, estimadamente, por 1,4 milhão de postos de trabalhos. Em 1999, o Ministério da Educação registrou a existência de 703 cursos de formação de técnicos e auxiliares de saúde, em que se formaram 28.862 alunos. Calcula-se que cerca de 225 mil dos trabalhadores exercem funções de saúde para as quais não estão devidamente preparados e certificados. A maioria dos trabalhadores sem credenciais está constituída por auxiliares que atuam na atenção de enfermagem em hospitais públicos e privados. O Ministério da Saúde está desenvolvendo atualmente um amplo projeto de financiamento e cooperação técnica - o ProfaE - que visa a reduzir esse déficit nacional de pessoal auxiliar qualificado em enfermagem, e, assim, diminuir o risco de práticas inadequadas e contribuir para a regularização e empregabilidade do pessoal auxiliar de enfermagem. 0 custo do projeto alcança a considerável cifra de US $\$ 370$ milhões, dos quais $50 \%$ financiados pelo Banco Interamericano de Desenvolvimento (BID). 
Um dos maiores desafios enfrentados pela política nacional de recursos humanos de saúde encontra-se em desenvolver capacidade institucional para prover educação permanente de pessoal em saúde da família. Para dar mais consistência técnica a esse treinamento e para buscar alternativas de capacitação através de cursos de especialização e de residências, vêm sendo constituídos, os chamados Pólos de Formação em Saúde da Família, junto a mais de vinte instituições de ensino de medicina e de enfermagem. Espera-se que essa articulação entre setor formador e o setor público empregador possa contribuir, a médio e longo prazos, para as mudanças e ajustes curriculares indispensáveis no âmbito da graduação desses dois profissionais.

\section{Financiamento}

Historicamente, o financiamento público da saúde no Brasil tem sido fortemente dependente de recursos federais. Em 1980, por exemplo, o financiamento federal correspondia a $75 \%$ do gasto público total. Em anos recentes, sobretudo em conseqüência do aumento dos recursos municipais, essa participação está em torno de $60 \%$. No ano 2000,0 gasto público total foi estimado em $\mathrm{R} \$ 34$ bilhões, o equivalente a $3,4 \%$ do PIB.

Até os primeiros anos da década de 1990, o financiamento federal contou com importante participação de recursos da previdência social, basicamente da contribuição de empregados e empregadores sobre a folha de salário. $\mathrm{Na}$ década anterior, essa contribuição respondeu, em média, por $80 \%$ do gasto federal com saúde. Na Constituição de 1988 , com a criação do Orçamento da Seguridade Social, foram instituídas contribuições sobre o faturamento das empresas (Contribuição para o Financiamento da Seguridade Social - Cofins) e sobre o lucro líquido de empresas (Contribuição sobre o Lucro Líquido - CSLL), que também se incorporaram ao financiamento federal da saúde. A partir do início dos anos 1990, recursos originários de contribuições sociais incidentes sobre o faturamento, lucro e movimentação 
financeira (esta última a partir de 1997) têm sido responsáveis, em média, por mais de $70 \%$ do financiamento federal da saúde.

Até 1993, a contribuição de empregados e empregadores sobre folha de salário ainda era, isoladamente, a principal fonte de financiamento do setor saúde no âmbito federal, correspondendo a 31,6\% do total. A partir de 1994, entretanto, essa contribuição passou a se destinar exclusivamente para o pagamento de encargos previdenciários, criando dificuldades ao financiamento da saúde. Nesse ano criou-se o Fundo Social de Emergência, posteriormente rebatizado como Fundo de Estabilização Fiscal (FEF), que foi a principal fonte de financiamento do gasto federal com saúde em 1994.

Desde o início da implementação do SUS, em 1990, o financiamento tem sido uma das questões centrais. Afinal, não se passa de um sistema de saúde dimensionado para 90 milhões de pessoas, como no auge da medicina previdenciária, para outro com responsabilidades atuais sobre mais de 160 milhões, sem um aporte significativo de recursos novos.

Os constituintes de 1988 já manifestavam preocupação com o financiamento da saúde, ao dispor no artigo 55 do Ato das Disposições Constitucionais Transitórias (ADCT) que, até ser aprovada a Lei de Diretrizes Orçamentárias (LDO), trinta por cento, no mínimo, do Orçamento da Seguridade Social, excluído o seguro desemprego, deveria ser destinado ao setor saúde. Este dispositivo foi colocado, nos anos subseqüentes, em algumas LDOs, servindo, contudo, mais como um teto orçamentário inicial, do que como garantia para a realização efetiva de despesas.

A crise financeira eclodiu em 1993, quando, em virtude do aumento das despesas da previdência social, os recursos originários sobre a contribuição de empregados e empregadores sobre a folha de salários, tradicionalmente utilizados para compor o financiamento da saúde, deixaram de ser repassados ao Ministério da Saúde. 
Assim, diante das dificuldades de financiamento do SUS, começaram a surgir no âmbito do Legislativo, desde 1993, diversas propostas para dar maior estabilidade ao financiamento setorial. Uma solução emergencial foi a criação da Contribuição Provisória sobre a Movimentação Financeira (CPMF) em 1996. Esta contribuição tem sido prorrogada desde então, deixando de ser uma contribuição exclusiva para a saúde, embora ao SUS ainda corresponda a maior parcela.

Finalmente, no ano 2000, foi aprovada a Emenda Constitucional no 29, que promoveu a vinculação de recursos para a saúde nos orçamentos das três esferas de governo, assegurando um patamar mínimo de recursos da União, estados e municípios. Estados e municípios foram obrigados a alocar, a partir de 2000 , pelo menos $7 \%$ das receitas resultantes de impostos e transferências constitucionais para a área da saúde. Esse percentual deve crescer gradualmente até atingir 12\% para estados e 15\% para municípios, até 2004. A União teve de destinar à saúde, no ano $2000,5 \%$ a mais do que despendeu em 1999; para os anos seguintes, o valor apurado no ano anterior deve ser corrigido pela variação nominal do PIB.

Ainda que, em última instância, o volume de recursos públicos para o setor dependa da evolução das receitas públicas, no caso de estados e municípios, e do crescimento da economia, no caso dos recursos da União, um dos pontos importantes dessa vinculação, a despeito das dificuldades encontradas em seu monitoramento, foi trazer maior segurança sobre o volume de recursos, representar uma espécie de 'seguro' contra a instabilidade excessiva, além de comprometer efetivamente as três esferas de governo no financiamento da saúde, quebrando a cultura da dependência ao financiamento federal.

Estimativas realizadas pelo Instituto de Pesquisa Econômica Aplicada (IPEA), para 1998, indicam a seguinte participação relativa das três instâncias de governo no financiamento público da saúde: União (63,0\%), estados $(20,6 \%)$ e municípios (16,4\%). Dados do Siops, referentes ao ano 2000 
(atualizados até 1/7/2002), anteriores, portanto, à vigência da Emenda Constitucional $n^{0} 29$, indicam redução da participação relativa dos estados $(18,5 \%)$ e da União $(59,9)$ e crescimento municipal $(21,6 \%)$.

Em valores absolutos, o gasto público total foi estimado em $\mathrm{R} \$ 33.982,3$ milhões no ano 2000 , sendo $\mathrm{R} \$ 20.351,5$ milhões correspondentes a recursos da União $(59,9 \%)$ e $R \$ 13.630,8$ milhões $(40,1 \%)$ oriundos de estados e municípios.

Em 1993-1994, o gasto líquido médio do Ministério da Saúde foi de $R \$ 111,91$ por habitante, valor que passou a $R \$ 146,72$ em 20002001, o que representa um crescimento de $31 \%$ no período. A análise ano a ano do gasto líquido per capita, por sua vez, revela que, desde 1995 , seu valor vem oscilando em torno de $R \$ 140,00$, mas com ligeira tendência de crescimento.

Os números apontam também para uma mudança importante de prioridades no financiamento federal. Em 1998, o financiamento das ações básicas de saúde absorvia 9,1\% do gasto per capita do Ministério da Saúde; em 2001, este percentual passou para 14,3\%, representando um crescimento de $57 \%$. Com essa política foram particularmente privilegiados iniciativas, como o Programa de Saúde da Família (PSF) e o Programa de Agentes Comunitários de Saúde (PAcs), considerados estratégicos para a mudança do modelo assistencial.

As alocações federais para o financiamento da assistência à saúde historicamente privilegiaram as regiões mais desenvolvidas com maior e melhor estrutura de oferta de serviços. A partilha dos recursos do INAmps, em 1986, refletia essa tradição histórica. 
Tabela 3 - Distribuição dos gastos com assistência médica. Brasil - 1986

\begin{tabular}{lrr}
\hline Região & \% do gasto & \% da população \\
\hline Norte & 2,27 & 5,48 \\
Nordeste & 18,10 & 28,82 \\
Sudeste & 59,28 & 43,79 \\
Sul & 15,14 & 15,12 \\
Centro-Oeste & 5,02 & 6,78 \\
Brasil & 100,0 & 100,0 \\
\hline
\end{tabular}

Fonte: Inamps/Secretaria de Planejamento/DIS, 1987.

Pode-se verificar que as regiões mais ricas, Sudeste e Sul, recebiam recursos proporcionalmente superiores à sua população, enquanto as regiões Nordeste e Norte recebiam recursos proporcionalmente inferiores às suas populações. A alocação de recursos, presidida pela disponibilidade de oferta, acabava privilegiando os estados que tinham maior capacidade instalada, em detrimento dos mais necessitados de recursos humanos e materiais. Era evidente que a redução das disparidades na alocação dos recursos federais regionais só aconteceria com a mudança nos critérios, mediante a adoção de políticas assistenciais e de investimentos diferenciadas, que tivessem como objetivo explícito a redução das desigualdades.

A implantação do Piso Assistencial Básico (PAB) que propicia a transferência regular e automática de $\mathrm{R} \$ 10,00$ per capita a todos os municípios brasileiros para o custeio de serviços básicos de saúde representou um passo importante em direção a uma maior equiidade na distribuição dos recursos do SUS, graças ao aporte da CPMF. Com essa iniciativa, adotada a partir de 1998, mais de $70 \%$ dos municípios viram aumentar significativamente os recursos disponiveis para atenção básica de saúde.

A evolução dos tetos financeiros da assistência à saúde, apresentada na Tabela 4, é elucidativa da política de redução das desigualdades regionais, quando comparada à situação vigente em 1986. A evolução dos percentuais destinados à atenção básica e aos serviços de média e alta complexidade indicam, por sua vez, que a diminuição das desigualdades inter-regionais não 
ficou restrita somente aos serviços de atenção básica, mas incluiu, também, os serviços ambulatoriais e hospitalares de maior complexidade.

Tabela 4 - Distribuição percentual dos tetos financeiros da assistência à saúde. Brasil e regiões - dezembro de 1997 a dezembro de 2001

Valores em \%

\begin{tabular}{lrrrrrr}
\hline Regióes & Atenção básica & \multicolumn{3}{c}{ Média e alta complexidade } & \multicolumn{2}{c}{ TơTAL } \\
\hline & 1997 & 2001 & 1997 & 2001 & 1997 & 2001 \\
Norte & 5,5 & 9,0 & 4,2 & 5,3 & 4,4 & 6,1 \\
Nordeste & 29,5 & 35,6 & 22,4 & 23,9 & 23,7 & 26,4 \\
Centro-0este & 6,6 & 7,7 & 6,3 & 6,4 & 6,3 & 6,7 \\
Sudeste & 43,7 & 34,7 & 50,1 & 47,9 & 48,9 & 45,0 \\
Sul & 14,7 & 13,2 & 17,0 & 16,5 & 16,6 & 15,7 \\
BrasiL & 100,0 & 100,0 & 100,0 & 100,0 & 100,0 & 100,0 \\
\hline
\end{tabular}

Fonte: SE/MS,

0 gasto nacional em saúde (público e privado) foi estimado, em 1997, em 6,5\% do PIB. Esse percentual está próximo ao de alguns países desenvolvidos como Reino Unido, Espanha e Canadá, onde os sistemas de saúde também são de acesso universal. Contudo, em valores per capita, o gasto nacional é muito inferior ao dos países referidos. Ademais, diferentemente de outros países com sistemas públicos de acesso universal, a participação do gasto público é bastante baixa em relação ao gasto nacional total - menos de $50 \%$, ao passo que o percentual médio dos países desenvolvidos é de $70 \%$ (Tabela 5).

Tabela 5 - Gasto em saúde, \% do PIB, per capita e participação de fontes públicas e privadas, estimativas para diversos países - 1997

\begin{tabular}{lrccc}
\hline País & \% PIB & Gasto (em US\$)per capita* & \% Público & \% Privado \\
\hline Alemanha & 10,5 & 2.365 & 77,7 & 22,3 \\
Austrália & 7,8 & 1.601 & 72,0 & 28,0 \\
Brasil & 6,5 & 428 & 48,7 & 51,3 \\
Canadá & 8,6 & 1.051 & 72,0 & 28,0 \\
Espanha & 8,0 & 1.211 & 70,6 & 29,4 \\
Estados Unidos & 13,7 & 3.724 & 44,1 & 55,9 \\
Reino Unido & 5,8 & 1.152 & 96,9 & 3,1 \\
\hline
\end{tabular}

* Em dólares internacionais (PPP).

Fonte: Informe sobre la salud en el mundo (Genebra: OMS, 2000). 
A magnitude do gasto privado em saúde no Brasil é explicada pela grande dimensão do setor de Planos e Seguros de Saúde. Este segmento é financiado pelo dispêndio das famílias e pelas despesas patronais com assistência à saúde de empregados e dependentes, e atende, de forma mais ou menos abrangente, cerca de $24,5 \%$ da população brasileira. Ademais, as famílias realizam importantes gastos diretos com medicamentos e assistência odontológica.

\section{Sistema de informação}

No Brasil, a produção e a utilização de informações sobre saúde se processam em um contexto muito complexo de relações institucionais, compreendendo variados mecanismos de gestão e financiamento. Estão envolvidas: estruturas governamentais nos três níveis de gestão do SUS; o IBGE, órgão coordenador do sistema brasileiro de geografia e estatística; outros setores da administração pública que produzem dados e informações de interesse para a saúde; instituições de ensino e pesquisa; associações técnico-científicas e as que congregam categorias profissionais ou funcionais e organizações não-governamentais.

Nas últimas décadas, importantes sistemas nacionais de informação foram desenvolvidos pelo Ministério da Saúde, com notáveis avanços na disseminação eletrônica de dados sobre nascimentos, óbitos, doenças de notificação, atendimentos hospitalares e ambulatoriais, atenção básica e orçamentos públicos em saúde, entre outros. Foram também construídos indicadores que servem de base para avaliar o cumprimento de metas e orientar o financiamento da atenção à saúde. Os principais sistemas de informação do Ministério da Saúde e suas características gerais são referidos a seguir:

- Sistema de Informações sobre Mortalidade (SIM) - é o mais antigo no país. Foi instituído pelo Ministério da Saúde em 1975, com dados consolidados a partir de 1979. Conta com apoio do Centro Brasileiro de Classificação de Doenças (CBCD), sediado na Faculdade de Saúde Pública da USP. O CBCD 
atua como referência nacional para informações sobre mortalidade e como centro colaborador da OMS para classificação de doenças em português. 0 registro da causa de morte baseia-se na Classificação Internacional de Doenças, estando implantada a 10 10 Revisão desde 1996.

- Sistema de Informações sobre Nascidos-Vivos (Sinasc) - foi concebido à semelhança do SIM e implantado gradualmente pelo Ministério da Saúde a partir de 1990. Propicia informações sobre nascidos-vivos, com dados sobre a gravidez, o parto e as condições da criança ao nascer. 0 documento básico é a Declaração de Nascido-Vivo (DN), padronizada nacionalmente e distribuída pelo Ministério da Saúde em três vias. Para os partos realizados em hospitais e outras instituições de saúde, a primeira via da DN deve ser preenchida e enviada à secretaria de Saúde correspondente. No caso de partos domiciliares, essa comunicação cumpre ser feita aos cartórios do registro civil.

- Sistema de Informações de Agravos de Notificação (SinaN) - tem como objetivo coletar, transmitir e disseminar, nas três esferas de governo, dados gerados rotineiramente pelo sistema de vigilância epidemiológica para apoiar processos de investigação e de análise das informações sobre doenças de notificação compulsória. Concebido como sistema modular e informatizado desde 0 nível local, pode ser operado a partir das unidades de saúde.

- Sistema de Informações Hospitalares do SUS (SIH/SUS) - foi concebido para operar o sistema de pagamento de internação aos hospitais contratados pelo Ministério da Previdência. Em 1986, foi estendido aos hospitais filantrópicos; em 1987, aos universitários e de ensino; e, em 1991, aos hospitais públicos municipais, estaduais e federais (administração indireta e outros ministérios). Reúne informações sobre $60-70 \%$ das internações hospitalares realizadas no país.

- Sistema de Informações Ambulatoriais do SUS (SIA/SUS) - é o sistema responsável pela captação e processamento das contas ambulatoriais do SUS, que representam mais de $\mathbf{1 3 0}$ milhões de atendimentos mensais. 
- Sistema de Informações da Atenção Básica (SIAB) - destina-se à coleta de informações aplicadas ao planejamento, acompanhamento e avaliação das atividades dos agentes comunitários de saúde e das equipes do Programa de Saúde da Família (PSF). Essas informações baseiam-se no cadastro das famílias atendidas e incluem dados demográficos, socioeconômicos, ambientais e culturais, além dos relativos à morbidade e à mortalidade.

- Sistema de Informações do Programa Nacional de Imunização (SI-PNI) - foi desenvolvido para orientar as ações do Programa Nacional de Imunizações (PNI), constituindo-se dos módulos de: apuração do programa de imunizações (API); estoque e distribuição de imunobiológicos (EDI); avaliação dos imunobiológicos utilizados (AIU); eventos adversos pós-vacinação (EAPV) e programa de avaliação do instrumento de supervisão (PAIs).

- Sistema de Informações sobre Orçamentos Públicos em Saúde (Sıops) - foi implantado pelo Ministério da Saúde em parceria com o Ministério Público Federal, a partir de 1999, com o objetivo de subsidiar o planejamento, a gestão, a avaliação e o controle social do financiamento e do gasto público em saúde nas três esferas de governo, mediante a formação e manutenção de um banco de dados sobre receitas e despesas com ações e serviços de saúde sob responsabilidade do poder público.

A disponibilidade desses dados tem motivado sua crescente utilização nas instituições de ensino de saúde pública. Entre as informações de outras fontes, que são essenciais para a análise das condições de saúde no Brasil, destacam-se as produzidas pelo IBGE. Além dos censos demográficos, o IBGE vem ampliando a realização de estudos amostrais de base domiciliar, que fornecem informações confiáveis, de âmbito nacional, sobre aspectos demográficos, socioeconômicos e de saúde. Outros setores de governo também produzem dados e informações que, embora se destinem a objetivos institucionais específicos, oferecem subsídios para a análise de saúde. 
Apesar desses avanços, persistem desafios tais como:

- ampliar o uso dessas informações para a gestão do sistema de saúde, em todos os níveis;

- promover maior articulação entre as instituições que atuam na produção, análise e disseminação das informações de interesse para a saúde;

- incentivar a contribuição da massa crítica de profissionais capacitados no país, para a análise dos dados disponíveis.

Nesse sentido, uma importante iniciativa tomada pelo Ministério da Saúde em 1996, em conjunto com a Opas, foi a criação da Rede Interagencial de Informações para a Saúde (RIPSA), que articula cerca de 40 entidades representativas dos segmentos técnicos e científicos nacionais envolvidos com o tema. A Ripsa publica anualmente um conjunto selecionado de Indicadores e Dados Básicos para a Saúde no Brasil (IDB), no total aproximado de 100 indicadores devidamente qualificados nas seguintes categorias: demográficos, socioeconômicos, mortalidade, morbidade e fatores de risco, recursos e cobertura. Vários estudos e análises têm sido realizados a partir desses dados, oferecendo contribuições importantes para decisões na área de saúde.

\section{Papel regulador}

Como qualquer outro setor da economia, a saúde requer 0 acompanhamento técnico-financeiro sistemático e a intervenção do gestor público na regulação dos bens produzidos e serviços oferecidos pela iniciativa privada, bem como na defesa dos seus consumidores e clientes. Para desempenhar esse papel, o governo não pode prescindir de estrutura administrativa adequada, legislação específica e quadro técnico capacitado.

No esteio da reforma do Estado, a institucionalização do modelo de Agência Executiva e do seu papel regulador sobre a economia apresentou- 
se como uma estratégia importante para a consecução desses objetivos. As agências reguladoras, expressão adotada e difundida pela nova estrutura administrativa, dispõem de maior liberdade de ação que os outros órgãos de governo em seus moldes tradicionais. Estabilidade dos dirigentes, capacidade de arrecadação, autonomia financeira e possibilidade de uma política de pessoal diferenciada são os principais fatores dessa distinção. A avaliação do desempenho da agência governamental é mais estrita: as normas presentes no seu contrato de gestão definem indicadores e metas cujo descumprimento injustificado autoriza a demissão do seu dirigente pela autoridade do órgão a que está vinculada.

Com base nesse modelo geral, o Ministério da Saúde tomou a iniciativa de criar duas agências: uma dedicada à regulação das atividades de saúde suplementar e outra, voltada à vigilância sanitária no Brasil.

Até o final da década de 1990, tornou-se lugar-comum a divulgação de denúncias sobre restrições de cobertura, ineficiência dos profissionais e insatisfação dos usuários com a qualidade dos serviços prestados pelos planos e seguros de saúde, e, sobretudo, com os aumentos abusivos nos valores das mensalidades e restrições de atendimento. Isto mostrou à opinião pública que esse mercado, não obstante a sua importância social, ainda não contava com uma regulamentação firme e eficaz. Em 1998, o Ministério da Saúde iniciou um processo de discussões com 0 objetivo de criar uma estrutura adequada e uma legislação específica e consistente, para a regulação da assistência privada supletiva à saúde no Brasil.

A Agência Nacional de Saúde Suplementar (ANS), vinculada ao Ministério da Saúde, instituída com a publicação da Lei 9.961, de 28 de janeiro de 2000 , representou a inserção definitiva da autoridade ministerial na regulamentação do mercado de medicina suplementar, até então da competência exclusiva da área econômica do governo, que limitava esse controle à supervisão do desempenho econômico-financeiro das empresas. Finalmente, a Lei 9.656, publicada no Diário Oficial da União de 4 de junho de 2000, 
trouxe garantias legais e benefícios evidentes no atendimento aos clientes dos planos de saúde:

1) exigência de atendimento a todos os agravos previstos no Código Internacional de Doenças (CID);

2) fixação de limites aos valores dos prêmios em função da faixa etária;

3) proibição da recusa de clientes com idade avançada;

4) proibição da exclusão de cobertura em função de doenças preexistentes, passados 24 meses da assinatura dos contratos;

5) ressarcimento pelas operadoras dos procedimentos prestados a seus clientes em hospitais vinculados ao SUS;

6) autorização à participação de empresas estrangeiras no mercado da assistência à saúde.

Por sua vez, a Agência Nacional de Vigilância Sanitária (Anvisa) tem como finalidade institucional promover a proteção da saúde da população por intermédio do controle sanitário da produção e da comercialização de produtos e serviços submetidos à vigilância sanitária, inclusive dos ambientes, processos, insumos e tecnologias. A agência também exerce o controle de portos, aeroportos e fronteiras, assim como a interlocução junto ao Ministério das Relações Exteriores e instituições estrangeiras sobre assuntos internacionais na área de vigilância sanitária.

Criada pela Lei 9.782, de 26 de janeiro de 1999, na qualidade de autarquia sob regime especial, sua independência administrativa e autonomia financeira lhe permitem gerar seus próprios recursos mediante a cobrança de taxas de fiscalização. Essa condição ampliou seu orçamento, que praticamente dobrou entre 1998 e 2001. Quando da sua instituição, a ANvisA incorporou as competências da antiga Secretaria de Vigilância Sanitária do Ministério da Saúde, às quais se somaram novas tarefas: coordenação do Sistema Nacional de Vigilância Sanităria, do Programa Nacional de Sangue e Hemoderivados, e do Programa Nacional de Prevenção e Controle de 
Infecções Hospitalares; atribuições relativas à regulamentação, controle e fiscalização da produção de fumígenos; suporte técnico na concessão de patentes pelo Instituto Nacional de Propriedade Industrial; controle da propaganda de produtos sujeitos ao regime de vigilância sanitária; e monitoração de preços de medicamentos e outros itens de interesse para a saúde.

A área de atuação da ANvISA é bastante abrangente, o que acaba por diluir a sua imagem institucional por trás de tantas atividades. Contudo, a agência vem adquirindo maior visibilidade pública com o impacto do volume crescente do registro de medicamentos genéricos, tarefa a ela atribuída.

\section{Tendências para a primeira década do século XXI}

Estudo Delphi realizado no IPEA em 2001 identificou tendências em diferentes áreas temáticas no campo da saúde. 0 Método Delphi é uma técnica prospectiva para obter informação essencialmente qualitativa, mas relativamente precisa sobre o futuro. Com este método, busca-se encontrar consensos em torno de determinados problemas entre pessoas de diferentes áreas, inclusive fora do sistema de saúde, escolhidas em função de sua inserção social e política, liderança, trajetória profissional, e, por isto, consideradas formadoras de opinião no segmento a que pertencem - organizações da sociedade civil e Ministério Público, gestores do SUS das três esferas de governo, diretores e gerentes da rede pública de saúde, profissionais de saúde, políticos, pesquisadores e docentes das áreas de saúde coletiva, economia e gestão da saúde, dirigentes da rede privada, e empresários e executivos da indústria farmacêutica, medicina supletiva e da área médico-hospitalar - ou mesmo além dele.

- Universalidade da atenção integral

A possibilidade de o SUS, no horizonte de dez anos, alcançar progressos marcantes no acesso a ações e serviços foi vista de forma positiva 
por $58 \%$ dos painelistas. Também estão divididas as opiniões quanto à possibilidade de o Programa de Saúde da Família (PSF) vir a ser efetivamente estendido a toda a população: $54,8 \%$ dos painelistas acham que essa extensão é 'pouco provável' ou 'não se efetivará'.

Já para $62,8 \%$ dos painelistas, a cobertura dos planos e seguros de saúde continuará aumentando na próxima década. Para $68,6 \%$ do painel, existe a possibilidade de o SUS adotar um elenco de ações e serviços preventivos e curativos que passe a ser 'efetivamente' garantido a toda a população usuária.

- Desigualdades

A possibilidade de o sistema de saúde obter resultados concretos na redução das desigualdades em saúde é reconhecida por $60,8 \%$ dos participantes da pesquisa. Contudo, não há simetria nesta percepção entre os diferentes grupos. A eqüidade, entendida como "igual acesso a tratamento para igual necessidade", será um objetivo prioritário da política de saúde na próxima década para $71,7 \%$ dos painelistas.

- Organização e gestão

Para quase três quartos dos painelistas $(74,4 \%)$, será reduzido o papel dos estados e municípios na prestação direta de serviços.

A tendência de transformação de hospitais e outras unidades operados pelo setor público em 'entes públicos', com maior autonomia, mas submetidos a alguma forma de controle social, é admitida por $86 \%$ dos painelistas no caso das unidades atualmente operadas pelo Ministério da Saúde. No caso das unidades operadas pelas secretarias estaduais de Saúde e das unidades operadas pelas secretarias municipais, os percentuais são também expressivos, embora mais baixos: $79,6 \% \mathrm{e}$ $78,9 \%$, respectivamente. 
0 setor privado empresarial, para 41,8\% dos painelistas, e as entidades públicas não estatais, segundo $41,0 \%$, serão as formas organizacionais que apresentarão maior crescimento na oferta de serviços médico-assistenciais.

0 mercado de trabalho para médicos generalistas crescerá tanto no setor público quanto na área privada em geral, segundo, respectivamente, a opinião de $82 \%$ e $75,5 \%$ dos participantes da pesquisa.

A exigência de titulação específica para o exercício de funções de direção nos estabelecimentos públicos de saúde, principalmente nos de maior porte, é uma tendência indicada por $77,2 \%$ dos painelistas.

- Financiamento

A maioria dos painelistas, quase $90 \%$, acredita na continuidade do crescimento do gasto nacional (público e privado) com saúde nesta primeira década do século XXI. Mas, para $72 \%$, o gasto privado crescerá em ritmo superior ao do gasto público. 0 pessimismo quanto à eficácia das estratégias de contenção de gastos atualmente utilizadas é manifestado por $56,7 \%$ dos painelistas.

As transferências financeiras do governo federal para estados e municípios serão mais diretas, regulares e automáticas para $80 \%$ dos painelistas, porém menos de $60 \%$ confiam na adoção de critérios mais transparentes e eqüitativos na definição dessas transferências

\section{Promoção da Saúde: discutindo uma nova política e um novo conceito de saúde}

A I Conferência Mundial de Promoção da Saúde, realizada em 1986 no Canadá, ficou mundialmente conhecida pela Carta de Ottawa. Esta Carta definiu a visão e o conceito de promoção da saúde. Saúde é conceituada não como o objetivo da existência humana, mas, sim, como a fonte de riqueza da 
vida cotidiana. Promoção da saúde consiste em proporcionar aos povos os meios para melhorarem sua situação sanitária e exercerem maior controle sobre sua saúde. São considerados condições e requisitos para a saúde: a paz, a educação, a moradia, a alimentação, a renda, o ecossistema estável, a justiça social e a equiidade. As estratégias para promover a saúde incluem o estabelecimento de políticas públicas saudáveis, a criação de ambientes favoráveis, o fortalecimento de ações comunitárias, a reorientação dos serviços de saúde e o desenvolvimento de habilidades e capacidades individuais, de forma a promover possibilidades de escolhas e oportunidades para perseguir a saúde e o desenvolvimento.

A Carta de Ottawa difunde a idéia de que saúde é um bem socialmente produzido. Saúde para todos é compromisso e responsabilidade de todos os setores da sociedade. Portanto, a estratégia de promoção da saúde demanda uma ação coordenada entre os diferentes setores sociais: as ações do Estado em suas políticas intersetoriais, da sociedade civil e do sistema de saúde propriamente dito.

A II Conferência Mundial de Promoção da Saúde, realizada em 1988 em Adelaide, na Austrália, reafirmou a de Ottawa quanto à definição dos determinantes de saúde e às condições de acesso eqüitativo aos bens e serviços em geral e, sobretudo, aos equipamentos e à assistência à saúde. 0 conceito de política pública saudável foi aprofundado, ressaltando-se a importância do compromisso político de todos os setores envolvidos com a saúde como condição de realização dessas políticas. Fortalece-se o entendimento de que as políticas públicas, em todos os setores, influenciam os determinantes de saúde e são o veículo principal das ações para reduzir as desigualdades sociais e econômicas. Quatro áreas prioritárias de ação foram identificadas na II Carta Mundial de Promoção da Saúde: saúde das mulheres, acesso à alimentação e a nutrientes saudáveis, redução do consumo de tabaco e álcool e criação de ambientes saudáveis.

As conferências seguintes foram realizadas em Sundsvall, Suécia, em 1991, e em Jacarta, Indonésia, em 1997. A Declaração de Jacarta estabe- 
leceu cinco prioridades para a promoção da saúde: promover a responsabilidade social pela saúde, aumentar as capacidades de ação e de proposição das comunidades, aumentar o 'empoderamento' (empowering) dos indivíduos e de suas comunidades, expandir e consolidar as parcerias para a promoção da saúde, aumentar investimentos na construção de infra-estrutura para a promoção da saúde.

A preocupação com a eqüidade está no centro do conceito de promoção da saúde e é o fio condutor de todas as Conferências e suas Declarações. A V Conferência, realizada em 2000 na cidade do México, ratificou o entendimento de que os determinantes das desigualdades em saúde têm melhorado significativamente, ainda que as circunstâncias de desigualdades sociais e econômicas continuem a corroer as condições de/para saúde. Por estas razões, a eqüidade, tanto no interior dos países como entre eles, foi seu tema central. Nesta Conferência, dez ministros de Saúde firmaram a Declaração Mundial do México para a Promoção da Saúde, que pode assim ser resumida: afirmação da contribuição das estratégias de promoção da saúde para manutenção das atividades de saúde em nível local, nacional e internacional; e compromisso dos países de desenharem planos nacionais de ação para monitorar o progresso feito pela incorporação das estratégias de promoção da saúde na política de planificação em nível nacional e local.

Estes encaminhamentos se justificam pelo reconhecimento da permanência de dois desafios: a importância de aprimorar os mecanismos de comunicação, através da divulgação de exemplos e evidências, das conquistas que demonstram que a política de promoção da saúde pode fazer diferença para a saúde e a qualidade de vida; e, da mesma forma, é uma estratégia que favorece $o$ alcance de uma equiidade maior em saúde.

A pauta das Conferências Mundiais de Promoção da Saúde é uma convocação à responsabilidade individual e coletiva na definição dos caminhos pelos quais podemos-devemos 'tecnocientificamente' modificar o mundo que nos cerca, e 'eticamente', repensar o(s) modo(s) de desenvolvimento e 
organização da vida em sociedade. Numa expressão: a estratégia da promoção da saúde coloca em destaque o desafio de desvendar as tramas que tecem as relações entre conhecimento, poder e ética.

\section{Um novo paradigma?}

Na modernidade, a estruturação do setor saúde se organiza em torno da atenção à doença, e há uma predominância da dinâmica dos hospitais como centro dessa assistência. No imaginário coletivo se confunde o discurso sobre saúde com doença, e o setor saúde como responsável por atender as enfermidades.

A definição de saúde da OMS marca a tentativa de superação desta perspectiva, que se estrutura melhor com o informe Lalonde de 1974, o qual aponta a necessidade da inversão dos orçamentos públicos canadenses com serviços assistenciais às doenças cujos gastos desconhecem os fatores determinantes das mesmas.

A Carta de Ottawa (1986), cuja base é o informe Lalonde, ao discutir políticas públicas e ambientes saudáveis, a importância da ação comunitária e o desenvolvimento de habilidades pessoais como estratégias para alcançar saúde, além de reorientação dos serviços, cumpre o papel de trazer esta pauta para a agenda política dos países.

No campo da saúde pública, fica cada vez mais reconhecida a incapacidade do modelo de atenção vigente - baseado hegemonicamente no conhecimento biológico, no parque tecnológico médico, no risco e atenção individual - para responder aos problemas de saúde da população. 0 aprofundamento deste debate reforça a discussão das ações e estratégias da promoção da saúde na América Latina e no mundo. A promoção da saúde reinaugura o debate de que a saúde não é um análogo inverso à doença, mas um conceito a ser socialmente construído e a servir de base para o trabalho do setor e a sociedade em seu conjunto. 
Há suficientes evidências empíricas para compreender que o enfoque biomédico não é capaz de explicar e intervir em toda a complexidade dos problemas de saúde-doença das populações e, por conseguinte, das formas de organização da sociedade para enfrentá-los. 0 aumento de fluxo de recursos para os serviços de saúde, tal qual estão constituídos, causa pouco impacto sobre o estado de saúde de uma população. Há uma necessidade crescente de recursos para satisfazer a voraz incorporação e expansão de tecnologias independentemente dos apontamentos epidemiológicos e avaliativos. A carga social das doenças, sequielas e mortes prematuras atuais está cada vez menos vinculada a mudanças e expansões adicionais dos serviços de saúde. As intervenções e mudanças estruturais fora da assistência sanitária clássica têm maior potencialidade de alterar as tendências epidemiológicas dos grandes problemas de saúde.

A busca incessante pela descoberta de fatores de riscos individuais e a prevenção de doenças específicas têm levado a respostas prescritivas e generalizadas. Por outro lado, o desenvolvimento da epidemiologia como a ciência da saúde pública tem sido também articulado a esta perspectiva hegemônica. 0 que sustentamos é que a crise do modelo biomédico é parte da crise da modernidade, que se caracteriza por não ter cumprido suas promessas, como liberdade, igualdade, solidariedade e paz. 0 século $\mathrm{XX}$ se caracterizou por aumento da pobreza, concentração de riquezas, contaminação e destruição ambiental, e nunca se vitimou tanto por guerras.

No Brasil, a promoção da saúde deve se confundir com a construção de sujeitos cidadãos, que se encontra assinalada nos princípios do SUS. o SUS é produto de um processo social de participação da sociedade civil para garantir acesso universal e integral à saúde e, portanto, faz parte do esforço da sociedade por qualidade de vida.

Os princípios do SUS estabeleceram as bases para a abordagem integral da saúde no Brasil, porém têm se centrado na organização dos 
serviços de atenção à doença. Esta dinâmica pode levar à inviabilidade financeira do sistema pela incorporação e utilização de tecnologias medicalizantes que não se pautam por critérios epidemiológicos, estando mais sensíveis a injunções do mercado.

Por outro lado, o grande acúmulo de capital social que representa o SUS ao marcar-se por dar acesso a um modelo biomédico, além da questão de sua sustentabilidade, é um movimento que, no campo da saúde, mantém a perspectiva hegemônica que não quebra o paradigma dominante de desenvolvimento.

A inserção do enfoque da promoção da saúde no SUS permite questionar a hegemonia do enfoque biomédico e recuperar as promessas da reforma sanitária brasileira, que apontam para uma abordagem da saúde em toda a sua complexidade. Neste sentido, cabe realçar a noção de que existe um elo indissociável entre promoção da saúde e desenvolvimento sustentável, tal como recomendado pela Associação Brasileira de Pós-Graduação em Saúde Coletiva (ABRasco) em documento de 2002:

A concepção de desenvolvimento sustentável, que engloba as diretrizes de intersetorialidade, deve orientar as políticas de emprego, moradia, acesso à terra, saneamento e ambiente, educação, segurança pública $\mathrm{e}$ segurança alimentar, para que, integradas às políticas de saúde, tenham por referência a saúde das populações como melhor indicador da qualidade de vida das pessoas e das coletividades.

\section{Políticas de promoção da saúde no Brasil}

Do ponto de vista legal e normativo, a promoção da saúde faz parte do elenco de responsabilidades do Estado, enunciadas na conceitualização de saúde, nos princípios e diretrizes organizacionais do SUS, que contemplam a participação comunitária e a integralidade do sistema, com gestão descentralizada, e apontam para a intersetorialidade. 
As normas pactuadas nacionalmente que regulam o processo de descentralização e a reorganização do modelo de atenção vêm introduzindo, com maior ou menor intensidade, a perspectiva da promoção da saúde. A Norma Operacional Básica do SUS - NOB 01/96, a mais explícita em relação a um novo modelo de atenção orientado para promover a saúde, apresenta como bases para sua estruturação:

- participação da população não somente nas instâncias formais, mas em outros espaços constituídos por atividades sistemáticas e permanentes, dentro dos próprios serviços de atendimento, favorecendo a criação de vínculos entre o serviço e os usuários, e caracterizando uma participação mais criativa e realizadora para as pessoas;

- concentração das ações de saúde na qualidade de vida das pessoas e no seu meio ambiente, bem como nas relações da equipe de saúde com a comunidade, especialmente com as famílias;

- modelo epidemiológico considerado como eixo de análise dos problemas de saúde, segundo o entendimento de que este incorpora como objeto de ação as pessoas, o ambiente e os comportamentos interpessoais;

- uso de tecnologias de educação e de comunicação social, elementos essenciais em qualquer nível de ação;

- construção da ética coletiva, que agrega as relações entre usuário, sistema e ambiente, e possibilita mudanças nos fatores determinantes, estimulando as pessoas a serem agentes de sua própria saúde;

- intervenções ambientais que suscitem articulações intersetoriais para promover, proteger e recuperar a saúde.

Considera-se, portanto, que, no processo de institucionalização do SUS, a promoção da saúde emerge e se fortalece como diretriz orientadora de uma Política Nacional de Saúde que represente a concretização das estratégias de promoção da saúde, isto é, que tenha como objetivo maior a saúde dos cidadãos, a ser construída com a participação da população, que propi- 
cie o desenvolvimento das potencialidades dos cidadãos e que reforce a ação comunitária, além de demonstrar potencialidades para reorganizar 0 sistema de atenção na perspectiva da saúde.

Se bem que os princípios e diretrizes da promoção da saúde estejam enunciados nas formulações jurídico-políticas da Política Nacional de Saúde, ainda não existe no Brasil uma política explícita, formalizada e instituída, que compreenda todas as dimensões da promoção de saúde. Um exemplo que ilustra a potencialidade de intervenções que articulam diferentes setores e ganham o apoio da sociedade está representado pelo conjunto de leis, normas e atos administrativos de combate ao uso do tabaco. Tais ações compreendem a obrigatoriedade do registro de produtos fumígenos pelas empresas produtoras, a proibição de venda de cigarros a crianças e adolescentes, a restrição de propaganda em veículos de comunicação, a proibição do uso de fumo em dependências de prédios públicos, a regulação dos teores máximos permitidos de alcatrão, nicotina e monóxido de carbono, e a proibição de fumo nas aeronaves em todo o território nacional. 


\section{Uma Iniciativa Exemplar de Promoção da Saúde: a experiência do Programa Agita São Paulo}

O Programa Agita São Paulo foi criado em 1996 para combater o sedentarismo no estado de São Paulo, aumentando o nível de atividade física e o conhecimento sobre os benefícios para a saúde de um estilo de vida ativo. É o resultado de um convênio entre a Secretaria de Estado da Saúde e o Centro de Estudos do Laboratório de Aptidão Física de São Caetano do Sul (CElafiscs), em parcerias que hoje envolvem mais de 200 instituições governamentais, não-governamentais e empresas privadas.

Dois desafios maiores tiveram que ser enfrentados na criação do programa. Primeiro, a escassez de trabalhos científicos na promoção da atividade física em países em desenvolvimento. Segundo, o estado de São Paulo compreendia uma população de 35 milhões de habitantes, numa área de 248,8 quilômetros quadrados, com 645 municípios. A região metropolitana de São Paulo, por sua vez, é a segunda maior do mundo, com mais de 16 milhões de habitantes. Num processo de planejamento de dois anos, o Celafiscs buscou a parceria de profissionais dos principais centros do Brasil e do exterior, como o Center for Diseases Control and Prevention (CDC), dos Estados Unidos, o Health Education Authority, na Inglaterra, e o Programa Agita Mundo.

Para desenvolver o programa, parcerias foram adotadas como estratégiachave. Parcerias intelectuais foram 0 instrumento para obter experiências de outras nações e programas internacionais. Vários profissionais experientes foram convidados a visitar o Centro Agita e compor um corpo científico nacional e internacional. As organizações parceiras governamentais e não-governamentais representaram o fator-chave para o sucesso do Agita. Mais de 220 instituições fortes formaram seus quadros executivos, que discutem as principais ações do Agita em reuniões mensais. Diferentes setores da sociedade foram representados neste quadro, como educação, esportes, saúde, indústria, comércio e serviços. A estrutura do Agita São Paulo mostra a relação entre os quadros científico e executivo. 
0 Agita tem sua mensagem principal associada às noções de 'vida ativa' e 'atividade física para a saúde', em substituição a termos tradicionais, como 'esporte' e 'fitness'. Pelo modelo 'um passo à frente', uma mensagem solicita aos sedentários que sejam mais ativos; aos ativos, que passem a ser regularmente ativos; e a quem já é ativo, que se torne muito ativo, para continuar a atividade sem lesões.

Três contextos foram selecionados: lar, transporte e tempo livre. Atividades caseiras diárias foram as mais reforçadas, concentrando-se na importância da caminhada (mesmo com um cachorro), jardinagem, tarefas de casa, comportamentos para evitar o sedentarismo (ficar sentado, assistir TV), mostrando-se o significado das atividades domésticas com humor para atrair a atenção dos brasileiros. Andar e subir escadas foram estimulados como meio de transporte. Dançar se tornou a inclusão mais importante para as atividades no tempo livre, pois crianças, adultos e idosos podem dançar, e os brasileiros amam dançar.

0 programa tem se difundido por outros estados, desenvolvendo uma rede brasileira e lançando o Agita Bahia e o Mexe Campina, entre outros, o que levou o Ministério da Saúde a convidar o Centro Agita para organizar o Agita Brasil. Com o objetivo de assegurar a implantação e implementação das atividades e ações do Programa Agita Brasil, o Ministério da Saúde vem estabelecendo parcerias com os gestores estaduais e municipais do Sistema Único de Saúde (SUS), além de contar com o respaldo técnico-científico do CELAFIscs para desenvolver ações de educação e promoção da saúde. Ao lado dessas alianças estão a Organização Pan-Americana da Saúde, o Conselho Nacional de Secretários de Saúde (Conass) e o Conselho Nacional de Secretários Municipais de Saúde (Conasems). 


\section{Funções Essenciais da Saúde Pública}

\section{Metodologia}

A maioria dos países das Américas expressou, em seus princípios de reforma do setor da saúde, a necessidade de alcançar a eqüidade de acesso a serviços, melhorando a qualidade e a eficiência dentro de um marco de sustentabilidade econômica e participação social. Apesar disso, em geral, os resultados do monitoramento dos processos de reforma na região mostram que não existe evidência na redução de desigualdades; que são escassos os avanços na efetividade e eficiência dos modelos de saúde; e em alguns países existe uma alta dependência financeira para a sustentabilidade dos serviços de saúde, sendo incipientes os processos de participação social. Também identificou-se um alto grau de deterioração da força de trabalho em saúde, em quantidade e qualidade, que afeta os serviços médicos clínicos e, em especial, a saúde pública.

A ênfase das reformas de saúde da década de 1990 foi dirigida à atenção médica individual, à redução dos déficits financeiros e aos processos de regulação/desregulação para a abertura de mercados de seguro. Estas reformas não atenderam às expectativas geradas, e seus resultados, em geral, são contraditórios com os direitos expressos nos mandados constitucionais.

Nos próximos anós, a nova geração de reformas tem como principais desafios: o processo de reconstrução da autoridade sanitária; o incentivo geracional para uma nova cultura da saúde, com participação cidadã e fortalecimento da infra-estrutura, da tecnologia e dos recursos humanos para o exercício de uma saúde pública capaz de enfrentar antigos e novos desafios para a proteção da saúde num mundo globalizado e com ampla diversidade de realidades locais. A nova geração de reformas tem o desafio de trabalhar com modelos de proteção e de inclusão social, incentivando os mecanismos de solidariedade e promovendo os direitos dos cidadãos. 
Em 1999, a Organização Pan-Americana da Saúde (OPas) lançou a Iniciativa Saúde Pública na Região das Américas como uma resposta orientada a fortalecer o papel das autoridades sanitárias no exercício do que se denominou Funções Essenciais de Saúde Pública (Fesp). Esta iniciativa tem como objetivo melhorar as práticas em saúde pública com base na medição das Fesp. 0 desenvolvimento da iniciativa e do instrumento de Fesp foi conduzido em conjunto pela OPAs, pelo Centro para o Controle de Doenças (CDC) e pelo Centro Latino-Americano de Investigação de Sistemas de Saúde (Classs). Também recebeu apoio do diretor emérito da 0pas/0MS, Dr. Carlyle Guerra de Macedo, e dos corpos diretivos da Instituição.

Em setembro de 2000, durante a sessão do Conselho Diretivo da OPAs, foi aprovada a Resolução 42/18, na qual os países-membros da região das Américas se comprometeram a participar do exercício regional de medição de desempenho das Fesp e a utilizar os resultados para elaborar Planos de Desenvolvimento Institucional para melhorar a prática da saúde pública.

0 uso das FESP oferece aos países uma excelente oportunidade para renovar os conceitos da saúde pública e refletir sobre as práticas institucionais. Uma saúde pública entendida como responsabilidade do Estado e da sociedade civil interessada numa saúde individual e coletiva que garanta 0 acesso equiitativo a serviços públicos e privados com qualidade e com uso racional dos recursos humanos e tecnológicos. Um exercício renovado da saúde pública que utilize o monitoramento, a análise e avaliação da situação da saúde das populações como instrumento de políticas de saúde para a organização de serviços individuais e para a vigilância, investigação e controle de riscos e danos em saúde pública. Uma saúde pública responsável, que interaja com os cidadãos e com a sociedade, para garantir transparência no uso dos recursos sociais mediante mecanismos de arrecadação de contas e participação cidadã.

0 desafio da autoridade sanitária é - e será de forma crescente vigiar, orientar e regular a gestão de múltiplos prestadores públicos e privados para cumprir as metas estabelecidas nos planos de saúde para a atenção 
da saúde individual e coletiva com critérios de eqüidade, eficiência, qualidade e sustentabilidade financeira.

Os cinco novos desafios para as autoridades sanitárias no exercício das FESP se relacionam com:

- melhorar a governabilidade sanitária a fim de incentivar as ações intersetoriais, gerando novas oportunidades para reconstituir o tecido social de sociedades segmentadas, para atuar sobre os determinantes da saúde e das desigualdades sociais, utilizando recursos públicos e privados;

- reestruturar a diretoria em saúde, utilizando as Fesp como fonte de inspiração;

- harmonizar os planos de saúde regionais e locais para a gestão de redes de serviços de saúde individual e coletiva em função dos resultados esperados;

- incrementar as ações de regulação quanto a mercados de seguro público e privado, assim como os processos de incorporação, uso e avaliação de tecnologias; e garantia de qualidade nos serviços de saúde individual e coletiva;

- melhorar os critérios de atribuição de recursos aos serviços de saúde individual e coletiva em função das necessidades, com critério redistributivo e solidário tanto para a operação dos serviços, como para os planos de investimento e renovação tecnológica.

A seguir, descrevem-se resumidamente as capacidades da autoridade sanitária com relação a cada uma das 11 Funções Essenciais de Saúde Pública (FEsP).

\section{Monitoramento e análise da situação da saúde}

A autoridade sanitária deve ter a capacidade de: dirigir e orientar sistemas integrais para a análise da situação de saúde e seus determinantes, com ênfase nas necessidades e nos riscos e danos de acesso a serviços de saúde individual e coletivo. Identificar os recursos intra e extra-setoriais 
(oferta pública e privada) para dar resposta às necessidades, riscos e demanda social. Desenvolver tecnologias, experiências, métodos e mecanismos de comunicação da informação para contribuir com o processo de tomada de decisões dos diferentes atores do governo e da sociedade. Manter critérios e procedimentos para garantir a qualidade dos bancos de dados e fontes de informação primária e secundária.

Entre os métodos e instrumentos requeridos para exercer esta função, a autoridade sanitária desenvolve perfis de situação para orientar os processos de atribuição de recursos, utilizando critérios de eqüidade; elabora tendências e parâmetros para o comportamento das diferentes variáveis e indicadores de recursos, produção e resultados esperados; e esboça protocolos para manter o sigilo de dados individuais.

\section{Vigilância e investigação de riscos em saúde pública}

As autoridades sanitárias devem ter capacidade de desenvolver sistemas idealmente integrados de vigilância e investigações sobre epidemias, comportamento de doenças que podem ser prevenidas, doenças não transmissiveis; acidentes, violências e outras patologias sociais; condições de vida e ambientais nocivas à saúde. Contarão com a infra-estrutura de saúde pública (redes de laboratório, redes de comunicação e outros) para estudos populacionais e investigações de caso, para dar uma resposta oportuna aos diversos problemas de saúde pública. Também devem desenvolver capacidade para a cooperação e ação de saúde pública internacional, orientada a proteger a saúde dos cidadãos em condições de migrações internas e externas favorecidas por diversas condições sociais e econômicas.

Estas capacidades da autoridade sanitária requerem uma estreita interação setorial e intersetorial entre as diferentes esferas de governo em nível nacional, intermediário e municipal, incluindo a garantia da informação pública, oportuna, adequada e educativa para a vigilância, controle dos problemas de saúde pública, fatores de risco e seus determinantes. 


\section{Promoção da saúde}

As autoridades sanitárias devem ter a capacidade de estimular e trabalhar pela promoção da saúde, incentivando condutas e ambientes saudáveis, trabalhando por uma nova cultura da saúde baseada na promoção de fatores protetores de riscos individuais e coletivos acessiveis a todos os cidadãos. Estas ações requererão, no mínimo, uma estreita aliança intersetorial com agentes governamentais e não-governamentais, e instituições acadêmicas, a promoção e avaliação de políticas públicas em saúde e a reorientação dos serviços com enfoques de promoção da saúde. Para gerar estas mudanças, é preciso contar com um enfoque de atribuição de recursos financeiros que incentive mudanças no comportamento dos modelos de atenção vigentes.

\section{Participação social dos cidadãos}

As autoridades sanitárias devem ter capacidade para reforçar o poder dos cidadãos e a participação das organizações comunitárias para mudar seus hábitos de vida e ser parte ativa do desenvolvimento do comportamento de ambientes saudáveis para influir nos fatores que afetam sua saúde e a entrega de serviços de saúde individual e coletivo. Fortalecer o poder dos cidadãos e das organizações comunitárias implica estimular os mecanismos de consulta pública e de informação sobre deveres e direitos em saúde; promover instâncias de proteção dos cidadãos e consumidores de serviços; estimular os mecanismos de comunicação e participação das comunidades organizadas e organismos comunitários na análise da situação de saúde e a gestão dos serviços individual e coletiva, bem como a fiscalização social do uso dos recursos do setor.

\section{Desenvolvimento de políticas e capacidade institucional de planificação e gestão em saúde}

A autoridade sanitária deve ter capacidade para definir, de forma participativa, objetivos de saúde pública em todos os níveis, que possam ser medidos, consistentes e orientados à redução de iniqüidades coerentes com 0 
contexto político, econômico e social do âmbito nacional, estatal e municipal. Esta capacidade institucional para a gestão de sistemas de saúde pública inclui a planificação e a formulação de objetivos sanitários, a implementação de respostas aos problemas identificados e a avaliação de resultados; implica o desenvolvimento de competências e a tomada de decisões baseadas na evidência; mecanismos de liderança e comunicação efetiva; desenvolvimento organizacional e gestão de recursos públicos e privados; e, finalmente, o desenvolvimento das capacidades para a cooperação internacional em saúde pública.

A formulação de objetivos sanitários/saúde pública com utilização dos perfis de situação de saúde e de gestão dos serviços de saúde individual e coletiva supõe um processo de identificação de prioridades sanitárias e de formulação de respostas de forma participativa, reflexiva, crítica, que envolve diferentes atores do governo e da sociedade. Estes processos requerem 0 desenvolvimento de liderança institucional e a comunicação social; a identificação de indicadores e mecanismos de seguimento e avaliação com padrões de excelência; o desenvolvimento organizacional e a gestão de recursos para o sucesso de resultados esperados, incluindo capacidades para negociar com as agências de cooperação internacional.

\section{Fortalecimento da capacidade institucional de regulação e fiscalização}

As autoridades sanitárias devem ter capacidade para desenvolver 0 marco regulatório para proteger a saúde pública e fiscalizar o seu cumprimento, assim como gerar leis e regulamentos que favoreçam a promoção da saúde e a construção de espaços saudáveis, e protejam os cidadãos em sua relação com os sistemas públicos e privados de saúde. Para elaborar este marco regulatório, deve-se levar em conta o desenvolvimento das FESP, as normas nacionais e internacionais e os avanços da ciência e tecnologia. Quanto às funções de fiscalização, propõe-se orientar os esforços à educação e à prevenção da corrupção e de transgressões. 


\section{Avaliação e promoção do acesso eqüitativo em saúde}

A autoridade sanitária deve ter capacidade para promover 0 acesso eqüitativo aos serviços de saúde individual e coletivo, incluindo o desenvolvimento de ações para superar as barreiras de acesso. Os processos de avaliação de acesso deverão realizar-se num ambiente multissetorial, multiético e pluricultural, trabalhando com diferentes instituições governamentais e não-governamentais, para dar solução às desigualdades observadas. Incentivam-se os mecanismos de informação sobre os direitos dos cidadãos e os mecanismos de acesso às redes de serviços de saúde individual e coletivo, modernizam-se os mecanismos de informação e comunicação sobre barreiras de acesso para os tomadores de decisão nos diferentes níveis de governo, incentivam-se as alianças inovadoras para a redução de iniqüidades de acesso a serviços e o tratamento especial às minorias vulneráveis.

\section{Desenvolvimento de recursos humanos e capacitação}

As autoridades sanitárias devem ter capacidade de desenvolver os recursos humanos em saúde pública adequados às necessidades de serviços individuais e coletivos. Estes recursos humanos requererão uma formação orientada a: identificar e avaliar as necessidades de serviços de saúde pública; definir e conduzir processos de certificação de profissionais e os processos de garantia de qualidade dos serviços de saúde individual e coletivo; contribuir para formar alianças estratégicas a fim de favorecer os processos de gestão de recursos humanos e desenvolvimento de liderança da saúde pública; desenvolver capacidades para 0 trabalho multidisciplinar em ambientes de diversidade cultural; desenvolver, formar e capacitar com valores éticos sociais baseados na eqüidade, solidariedade e respeito aos direitos e à dignidade das pessoas. Para apoiar o exercício desta função, devem-se manter e atualizar as bases de dados e análise do mercado de trabalho dos profissionais e 
técnicos da saúde, a fim de apoiar o processo de tomada de decisão quanto às necessidades presentes e futuras.

\section{Garantia de qualidade dos serviços de saúde individual e coletiva}

As autoridades sanitárias devem ter capacidade para desenvolver sistemas de avaliação e garantia de qualidade mediante a geração de normas e padrões de qualidade para a estrutura, processo e resultado das ações de saúde individual e coletiva; incentivar a informação dos deveres e direitos dos usuários; estabelecer sistemas integrados ou interdependentes de gestão e avaliação de tecnologias para contribuir com a segurança, qualidade e o uso racional de recursos tecnológicos; incentivar o uso da metodologia científica para avaliar as intervenções em saúde em diferentes níveis de complexidade; e estimular os sistemas de avaliação da satisfação dos usuários e desempenho dos serviços de saúde.

\section{Investigação em saúde pública}

As autoridades sanitárias devem ter capacidade para incentivar a investigação e 0 uso de seus resultados no processo de tomada de decisões, bem como para desenvolver e usar soluções inovadoras em saúde pública cujo impacto possa ser medido e avaliado. 0 desenvolvimento desta função requer alianças estratégicas entre os diferentes atores do governo e da sociedade, para definir uma agenda estratégica de investigações que apóie os processos de tomada de decisão no exercício pleno da autoridade sanitária. Estimulam-se os processos de participação ativa para a formulação e uso das investigações, garantindo sua qualidade e oportunidade.

\section{Redução do impacto de emergências e desastres}

As autoridades sanitárias devem ter capacidade para desenvolver políticas de planificação e execução de ações para a mitigação, preparação 
e reabilitação prévia para reduzir o impacto das emergências e desastres sobre a saúde pública, incentivando a participação intersetorial, setorial e a cooperação internacional. Estimula-se a produção de normas de construção e manutenção de instituições e serviços de saúde para a preparação de desastres e a redução da vulnerabilidade física e orgânica, o desenvolvimento de infra-estrutura e equipes em áreas suscetiveis a desastres, a produção de uma lista de medicamentos e insumos necessários em caso de emergência e/ou desastres, e o desenvolvimento de medidas de emergência sanitária em caso de epidemias.

\section{Resultados da avaliação das Funções Essenciais da Saúde Pública no Brasil}

o Ministério da Saúde do Brasil e a Opas acordaram, no final de 2001, a aplicação do instrumento de Funções Essenciais de Saúde Pública (FESP) no âmbito do SUS. Este acordo foi fruto de um amplo consenso entre os dirigentes do Ministério e as instâncias colegiadas do SUS. Para operacionalizar o processo de aplicação, a OPAS/OMS apoiou a formação de facilitadores e a simulação do processo antes da convocatória nacional. A medição de desempenho das Fesp foi realizada de 15 a 17 de abril de 2002, com a participação de cerca de 65 dirigentes do SUS das três esferas de governo, do Conselho Nacional de Saúde (CNS), do Conselho de Secretários Estatais de Saúde (Conass), do Conselho de Secretários Municipais de Saúde (Conasems) e do setor acadêmico.

Esta reunião foi organizada pelo Ministério da Saúde, com a colaboração da Representação da OPAS/OMS e da Divisão de Desenvolvimento de Sistemas e Serviços de Saúde OPAS/OMS. Este processo mostra o grau de compromisso do Ministério da Saúde com a iniciativa de saúde pública na região das Américas. 0 Ministério da Saúde e a OpAS/OMS destacaram, neste processo, seu compromisso de fortalecer o papel da autoridade sanitária para garantir serviços de saúde a todos os brasileiros e dar 
seguimento aos acordos com relação ao uso da medição das FESP na elaboração de planos de desenvolvimento institucional para fortalecer 0 papel de condução e diretoria setorial.

0 contexto da aplicação do instrumento de Fesp realizou-se em função do exercício da autoridade sanitária nacional, incluído o desempenho das três esferas de governo. 0 instrumento utilizado contém as 11 Funções Essenciais de Saúde Pública. 0 informe preliminar dos resultados da aplicação do instrumento de Fesp no Brasil destaca a opinião favorável dos participantes quanto à importância das Fesp para o futuro desenvolvimento da saúde pública no país e o incentivo ao uso de processos de autoavaliação, em nível nacional e sub-regional, para promover a construção de planos de desenvolvimento e fortalecimento da saúde pública. As diferentes submedições de estrutura, processo e resultados para cada função possibilitou aos gestores do SUS identificar seus pontos fortes e fracos num processo democrático, que lhes permitiu refletir sobre o grau de desenvolvimento institucional para exercer cada uma das Fesp. Os participantes também opinaram criticamente sobre 0 instrumento de medição e suas limitações, para lograr uma avaliação mais detalhada da complexa realidade do sistema nacional de saúde, e ofereceram sugestões para seu melhoramento. Recomendou-se incentivar a aplicação do instrumento de FESP, adaptado aos níveis estatais, a fim de dar especificidade aos Planos de Desenvolvimento Institucional, de acordo com a diversidade e complexidade dos estados do Brasil.

O exercício das Fesp no Brasil convocou os mais altos e qualificados dirigentes do SUS, da comunidade acadêmica e organismos colegiados, para garantir os resultados da medição em cada um dos grupos compostos.

- FEsP com desempenho alto

FEsP 6 - Fortalecimento da função de institucionalização e regulação da saúde pública; Fess 1 - Monitoramento e análise da situação da saúde; FEsP 7 
- Avaliação e promoção do acesso equiitativo aos serviços de saúde e investigação em saúde pública.

A criação da Agência Nacional de Vigilância Sanitária (Anvisa) e da Agência Nacional de Saúde Suplementar (ANSS) representou um passo decisivo no processo de modernização das funções reguladoras do setor saúde. No primeiro caso, orientado à regulação dos mercados públicos e privados de bens e serviços de saúde, e, no segundo, à regulação de um mercado de planos e seguros de saúde dirigidos a grupos com capacidade de pagamento direto ou indireto.

0 monitoramento e análise da situação de saúde tem alto grau de inserção na gestão pública dos serviços de saúde coletiva, que apresenta profundas transformações com os processos de descentralização e especialização de funções da Fundação Nacional de Saúde. Um projeto de modernização de sua estrutura e funções encontra-se em curso para ser aprovado. 0 Brasil conta com excelentes instituições acadêmicas, que favorecem os processos de análise de situação da saúde e medição de desigualdades. A ABRAsco, a Rede de Informações para a Saúde (RIPSA - MS/OpAs) e as recentes redes de Observatórios especializados em reforma do setor saúde em nível de alguns estados conformam uma força crítica nacional que contribui para o alto grau de cumprimento desta função. Os gestores do SUS, em nível nacional, são conscientes da necessidade de fortalecer estas capacidades nos níveis subnacionais (estatais e municipais) para utilizar guias de monitoramento e avaliação integradas para garantir o sucesso de resultados com relação a doenças infecciosas, crônicas e degenerativas que afetam a população com diferente intensidade, segundo a região social e econômica.

A recente expedição e implementação da Norma Operacional de Assistência em Saúde (NoAs/2001) e os crescentes processos de habilitação da Gestão Plena dos Estados no Brasil influíram de forma substancial para dar uma alta qualificação a esta função. A NoAs/2001 incentiva a elaboração de Planos de Desenvolvimento Regional de Serviços de Saúde Individual e 
Planos de Investimento para fortalecer, em especial, a atenção básica ampliada e os serviços de média complexidade em cada um dos estados. Esta Norma gera um processo de habilitação em função de um novo ordenamento regional para os serviços de saúde. Os processos de habilitação dos estados em gestão plena reconfiguram as responsabilidades da autoridade sanitária, dando ao Estado, como uma de suas funções, a de cooperação técnica para a harmonização e complementaridade dos planos regionais de saúde individual e coletiva. 0 Brasil utiliza modelos de avaliação nos quais constam informação epidemiológica, demográfica, social e econômica para os processos de planificação e gestão de serviços. Finalmente, neste grupo, a investigação para o desenvolvimento da saúde pública conta com instituições como FrocRUz, Funasa e Abrasco, que contam com uma agenda nacional de investigação elaborada em função de prioridades nacionais. Os resultados das investigações contribuem para o processo de formulação de políticas e para a gestão pública dos serviços oferecidos pelo SUS.

- Fesp com desempenho médio alto

Fesp 4 - Participação dos cidadãos em saúde; Fesp 2 - Vigilância e investigação de controle de riscos e danos em saúde; Fesp 3 - Promoção da saúde; FESP 5 - Desenvolvimento de políticas e capacidade institucional para a gestão da saúde pública.

Estas funções apresentam grandes pontos fortes e uma capacidade potencial de superação de obstáculos com relação à planificação e gestão dos processos de saúde coletiva. Identificaram-se possibilidades de melhoria na capacidade e uso da rede de laboratórios de saúde pública; na capacidade e uso da epidemiologia, demografia e enfoques de promoção da saúde na autoridade sanitária estatal em apoio aos planos regionais de saúde; e a potencialidade de gerar mudanças, o desenvolvimento da capacidade e competência dos sistemas de saúde pública, em especial no nível das Secretarias Estatais de Saúde. 
- Fesp com desempenho médio baixo

Fesp 8 - Desenvolvimento de recursos humanos e capacitação em saúde pública; Fesp 9 - Garantia de qualidade de serviços de saúde individuais e coletivos, e a redução do impacto de emergências e desastres em saúde.

0 desenvolvimento dos recursos humanos tem um grande desafio para lograr uma substancial melhoria da qualidade da força de trabalho e dos processos de educação contínua e de pós-graduação em saúde pública relacionados com a diversidade cultural e social do Brasil.

O exercício das Fesp permitiu identificar a necessidade de trabalhar de forma urgente para melhorar os sistemas de gestão tecnológica e avaliação de tecnologias em saúde para apoiar os processos de tomada de decisão e avançar na cooperação técnica, a fim de garantir a qualidade dos serviços de saúde individual e coletiva.

\section{Recomendações}

Os pontos fortes do SUS no Brasil identificados pelo instrumento de FEsp permitem afirmar que existe uma alta capacidade institucional para enfrentar os seguintes desafios:

- Consolidar e aprofundar a aplicação da planificação e gestão de serviços individuais de saúde com enfoque regionalizado, orientado à redução de iniqüidades de acesso, incentivando o uso de ferramentas de medição de desigualdades para o desenvolvimento dos planos de regionalização e investimento em saúde.

- Impulsionar a complementaridade da NoAs/2001, com uma proposta orientada a fortalecer e gerar capacidades para a planificação e gestão dos serviços de saúde coletiva com enfoque macro e microrregional, incentivando os processos de participação social, a intersetorialidade e novos enfoques de financiamento e pagamento para a saúde coletiva. 
- Esboçar e implementar uma estratégia para fortalecer as funções reguladoras sobre Gestão e Avaliação de Tecnologias no âmbito do SUS e dos sistemas de seguro privado; incentivar o uso de protocolos e normas clínicas orientados a evitar condutas evitáveis ou desnecessárias.

- Fortalecer a capacidade institucional dos gestores do SUS para garantir a qualidade dos serviços de saúde individual e coletiva, com ênfase na atenção básica e saúde da família e nos serviços críticos de média e alta complexidades.

- Gerar um plano integral de desenvolvimento de recursos humanos como fator essencial de qualidade institucional para renovar as capacidades dos gestores do SUS em relação a manter os pontos fortes e superar os pontos fracos identificados no exercício das Fesp.

- Incentivar o uso e a aplicação das Fesp no nível dos estados para apoiar os processos de modernização das Secretarias Estatais e a elaboração de planos de desenvolvimento da saúde pública.

\section{Bibliografia}

BARROS, M. E. D.; PIOLA, S. F. \& VIANNA, S. M. Política de Saúde no Brasil: diagnóstico e perspectivas. Brasília: Instituto de Pesquisa Econômica Aplicada (Ipea), 1996. (Texto para Discussão n² 401.)

BRASIL. Ministério do Planejamento e Coordenação Econômica/Escritório de Pesquisa Econômica Aplicada (Epea). Plano Decenal de Desenvolvimento Econômico e Social. Previdência Social Diagnóstico Preliminar, abr., 1966.

BRASIL. Ministério da Saúde. Plano de Coordenação das Atividades de Proteção e Recuperação da Saúde. Rio de Janeiro, 1968.

BRASIL. Ministério da Saúde. Política Nacional de Saúde. Brasília, 1973.

BRASIL. Ministério da Saúde. Sistema Nacional de Saúde. Anais da V Conferência Nacional de Saúde. Brasília, 1975.

BRASIL. Ministério da Saúde/Programa de Interiorização de Ações de Saúde e Saneamento no Nordeste (Piass). Exposição de Motivos Interministerial no 229, de 18/08/1976. Brasília, 1976. (Mimeo.)

BRASIL. Instituto de Pesquisa Econômica Aplicada (Ipea). O Brasil na Virada do Milênio. Brasília: Ipea, jul., 1977. v. II.

BRASIL. Ministério da Saúde. 2. ed. Promoção da Saúde: Declaração de Alma-Ata, Carta de 
Ottawa, Declaração de Adelaide, Declaração de Sundsvall, Declaração de Santa Fé de Bogotá, Declaração de Jacarta, rede de megapaíses e Declaração do México. Brasília, 2001.

BRASIL. Ministério da Saúde. Sistema de Informações sobre Orçamentos Públicos em Saúde (Siops). Brasília: Impresso Publicação da Diretoria de Projetos da Secretaria de Gestão de Investimentos em Saúde, jul., 2002.

BRASIL. Ministério da Saúde. Vamos Promover nossa Saúde? Brasília, 2002.

BRASIL. Ministério da Saúde. Política Nacional de Promoção da Saúde: documento para discussão. Secretaria de Políticas de Saúde, nov.- dez., 2002.

BRASIL. Ministério da Saúde. Análise de Alguns Aspectos do Processo de Descentralização no Sistema Único de Saúde. Ministério da Saúde (Secretaria de Assistência à Saúde/ Secretaria de Políticas de Saúde), s.d.

CAMPOS, 0. Planejamento Setorial de Saúde. Rio de Janeiro: Fundação de Recursos Humanos para a Saúde, s.d. (Departamento de Administração e Planejamento.)

DONNANGELO, M. C. F. Medicina e Sociedade: o médico e seu mercado de trabalbo. São Paulo: Pioneira, 1975.

GENTILE DE MELlo, C. Saúde e Assistência Médica no Brasil. São Paulo: Cebes/Hucitec, 1977.

LUZ, M. T. As Instituições Médicas no Brasil: instituição e estratégia de begemonia. Rio de Janeiro: Edições Graal, 1979.

MACHADO, M. H. (Coord.) Os Médicos no Brasil: um retrato da realidade. Rio de Janeiro: Editora Fiocruz, 1997.

NUNES, A. et al. (Coords.) Medindo as Desigualdades em Saúde no Brasil. Brasília: Opas/ OMS/Ipea., 2001.

ORGANIZACIÓN PANAMERICANA DE LA SALUD (OPAS). La Salud en las Américas, 2002 Brasil. Brasília, 2002. (Situação geral e de saúde e tendências.)

ORGANIZACIÓN PANAMERICANA DE LA SALUd (OPAS). La Salud Pública en las Américas, nuevos conceptos, análisis del desempeño y bases para la acción. Washington, D.C.: Opas, nov.-dez., 2002.

PIOLA, S.; VIANNA, S. M. \& VIVAS, D. C. Tendências do Sistema de Saúde no Brásil (Estudo Delphi). Brasília: Instituto de Pesquisas Econômica Aplicada (Ipea), 2001.

PIOLA, S.; VIANNA, S. M. \& OSÓRIO, R. G. Saúde no Brasil na Década de 1990. Brasília: Instituto de Pesquisa Econômica Aplicada (Ipea), jun., 2002.

PORTO, S. M. et al. Metodologia de Alocação Eqüitativa de Recursos (Relatório Final) Rio de Janeiro: Fiocruz (Fundação Ensptec), jan., 2002.

RODRIGUES, B. de A. Fundamentos de Administração Sanitária. Rio de Janeiro: Freitas Bastos, 1967.

SIIVA, F. A. R. da \& MAHAR, D. Saúde e Previdência Social: uma análise econômica. Rio de Janeiro: Ipea/Inpes 1974. (Relatório de Pesquisa, 21.)

SINGER, P.; CAMPOS, 0. \& OLIVEIRA, E. M. Prevenir e curar: o controle social através dos serviços de saúde. Rio de Janeiro: Forense Universitária, 1978. 
VIANNA, S. M.A Problemática Administrativa do Setor Saúde. Rio de Janeiro: Escola Superior de Guerra, 1971. (Trabalho de Turma, TTI-123-71.)

VIANNA, S. M. A Assistência Odontológica no Sistema Nacional de Saúde, 1977. Brasília: Tese de Livre Docência apresentada ao Instituto de Patologia Tropical da Universidade Federal de Goiás.

VIANNA, S. M. Revisitando a Distribuição de Encargos na Saúde entre Esferas de Governo (Projeto PNUD BRA/97/013 - Financiamento e gestão na área da saúde) Instituto de Pesquisa Econômica Aplicada (Ipea), maio 2000. (Mimeo.) 


\section{IMAGENS}

Nísia Trindade Lima

Coordenadora

Cristiane Batista • Roberto Jesus Oscar - Vinícius Pequeno de Souza 


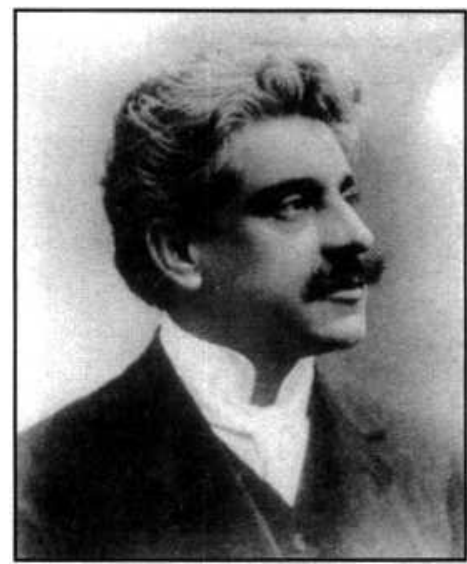

Oswaldo Cruz, 1903.

Acervo da Casa de Oswaldo Cruz.

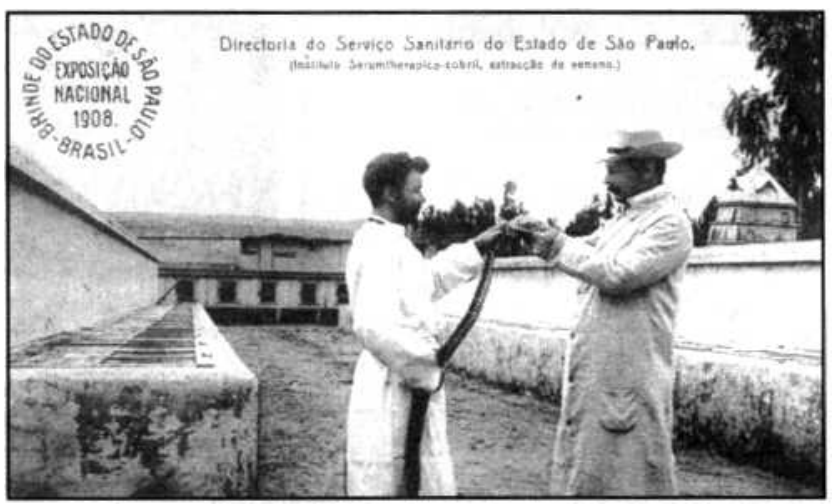

Instituto Butantan, 1908 .

Benchimol \& TeixerR, Cobras, Lagartos e Outros Bicbos. Rio de Janeiro: Editora UFRJ/FrockIz, 1993.

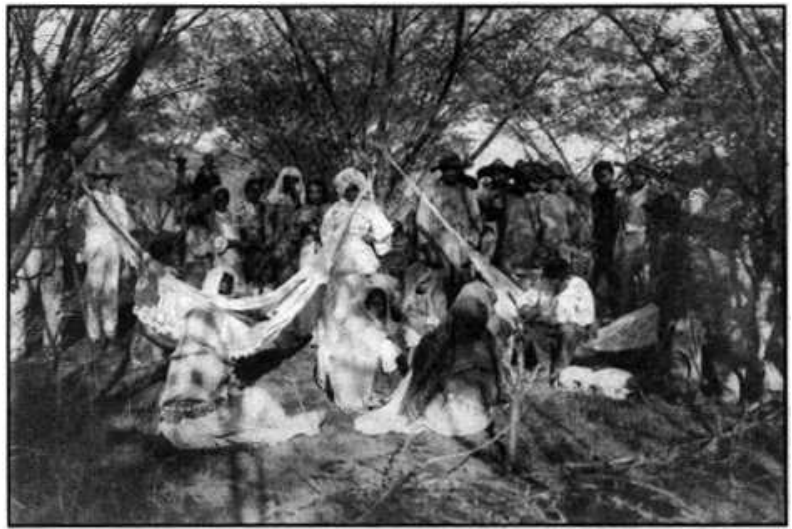

Belisário Penna dando consultas sob uma jurema em Lages, PI, maio de 1912.

THiren et al. A Ciência a Caminho da Roça: imagens das expediçöes cientificas do Instituto Oswaldo Cruz ao interior do Brasil entre 1911 e 1913. Rio de Janeiro: Editora Frocruz, 2002. 


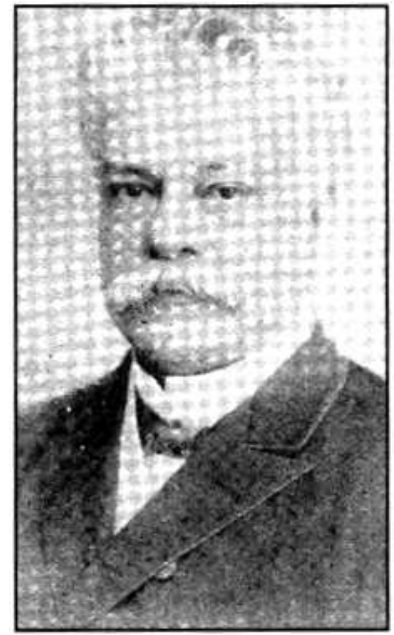

Bento Gonçalves Cruz, representante do Brasil na VIII Conferência Sanitária Pan-Americana da Saúde, realizada en 1928.

Acervo da Casa de Oswaldo Cruz.

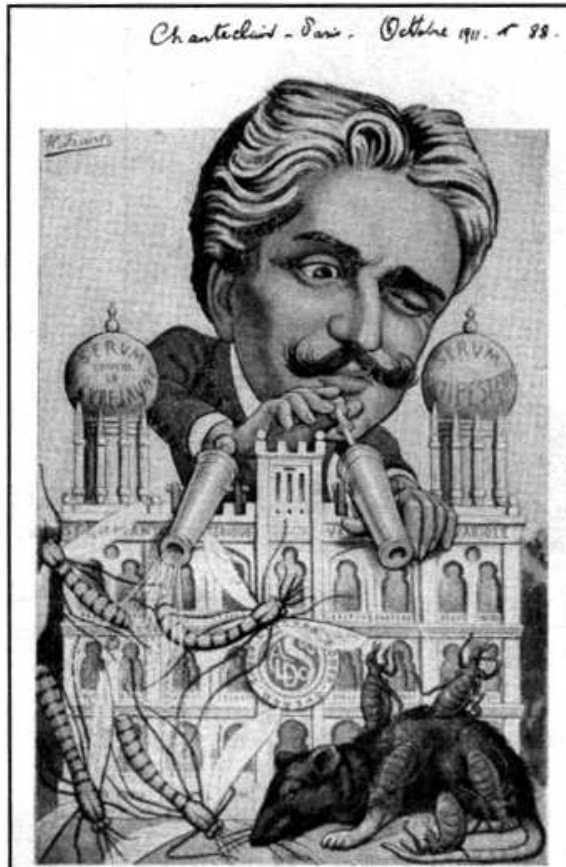

Le Desteur Cswalde Creta. de Rie-de-janeire

Caricatura de Oswaldo Cruz sobre o Castelo de Manguinhos combatendo mosquitos e ratos. Alusão à campanha contra a febre amarela e a peste bubônica. Acerwo da Casa de Oswaldo Cruz.

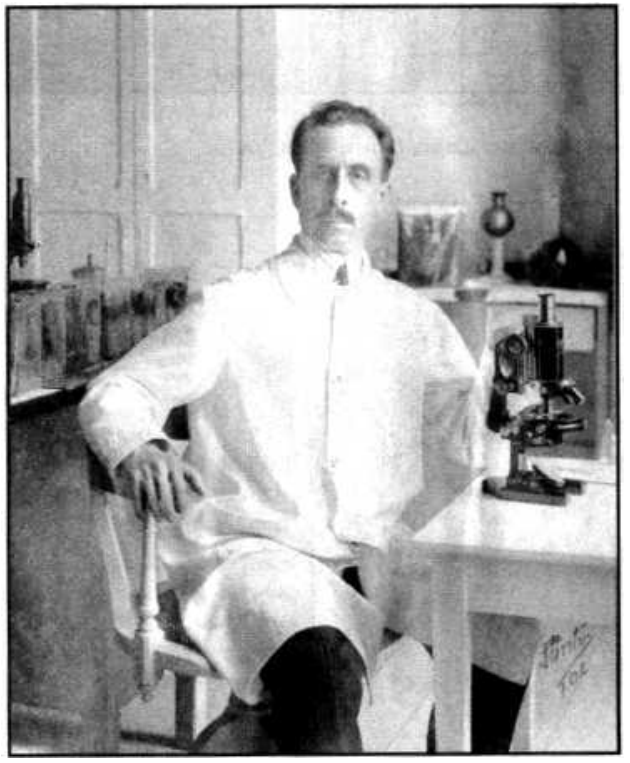

Carlos Chagas, 1929.0 cientista dirigiu o Instituto Oswaldo Cruz (1917-1934) e participou da diretoria da OPAs (1920-1924).

Acervo da Casa de Oswaldo Cruz. 


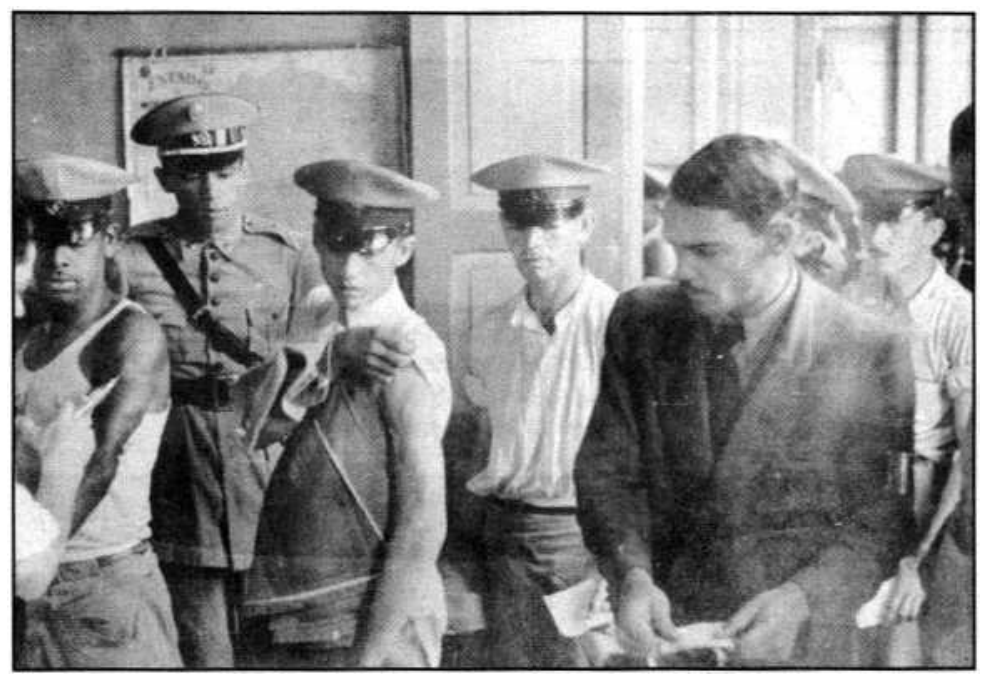

Vacinação contra a febre amarela realizada na Força Pública, MG, década de 1940. Acervo da Casa de Oswaldo Cruz.
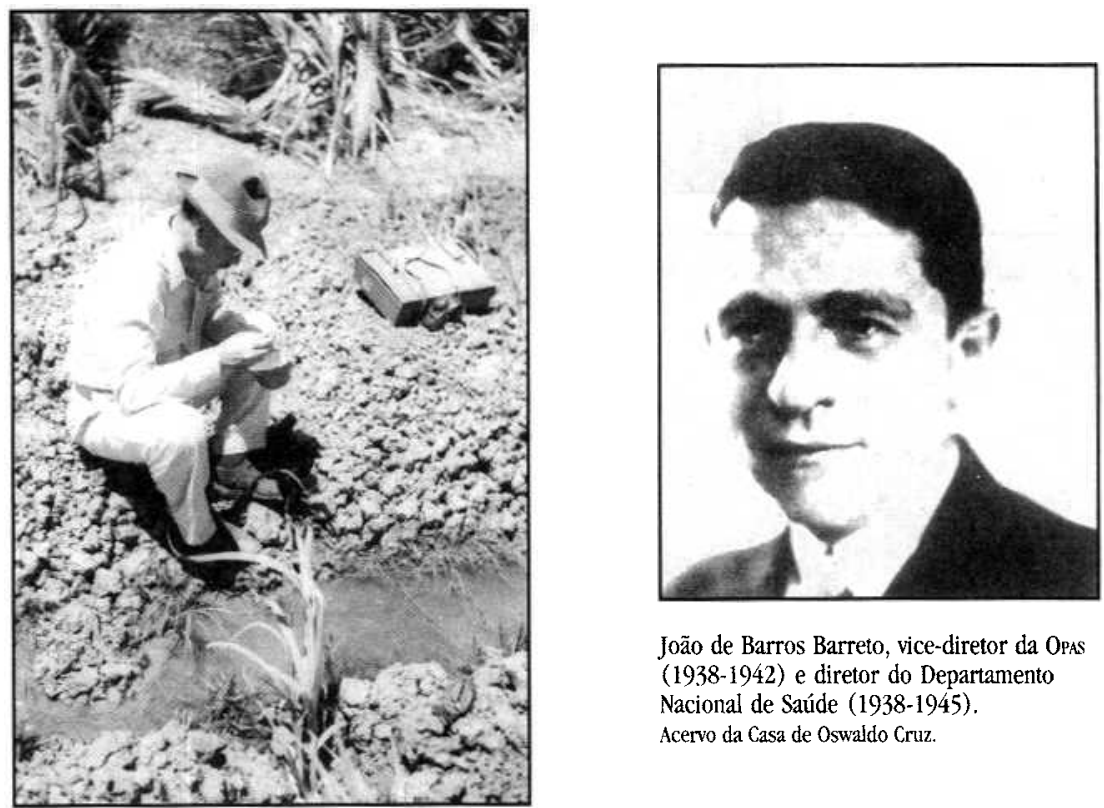

João de Barros Barreto, vice-diretor da OpAs (1938-1942) e diretor do Departamento Nacional de Saúde (1938-1945). Acervo da Casa de Oswaldo Cruz. 

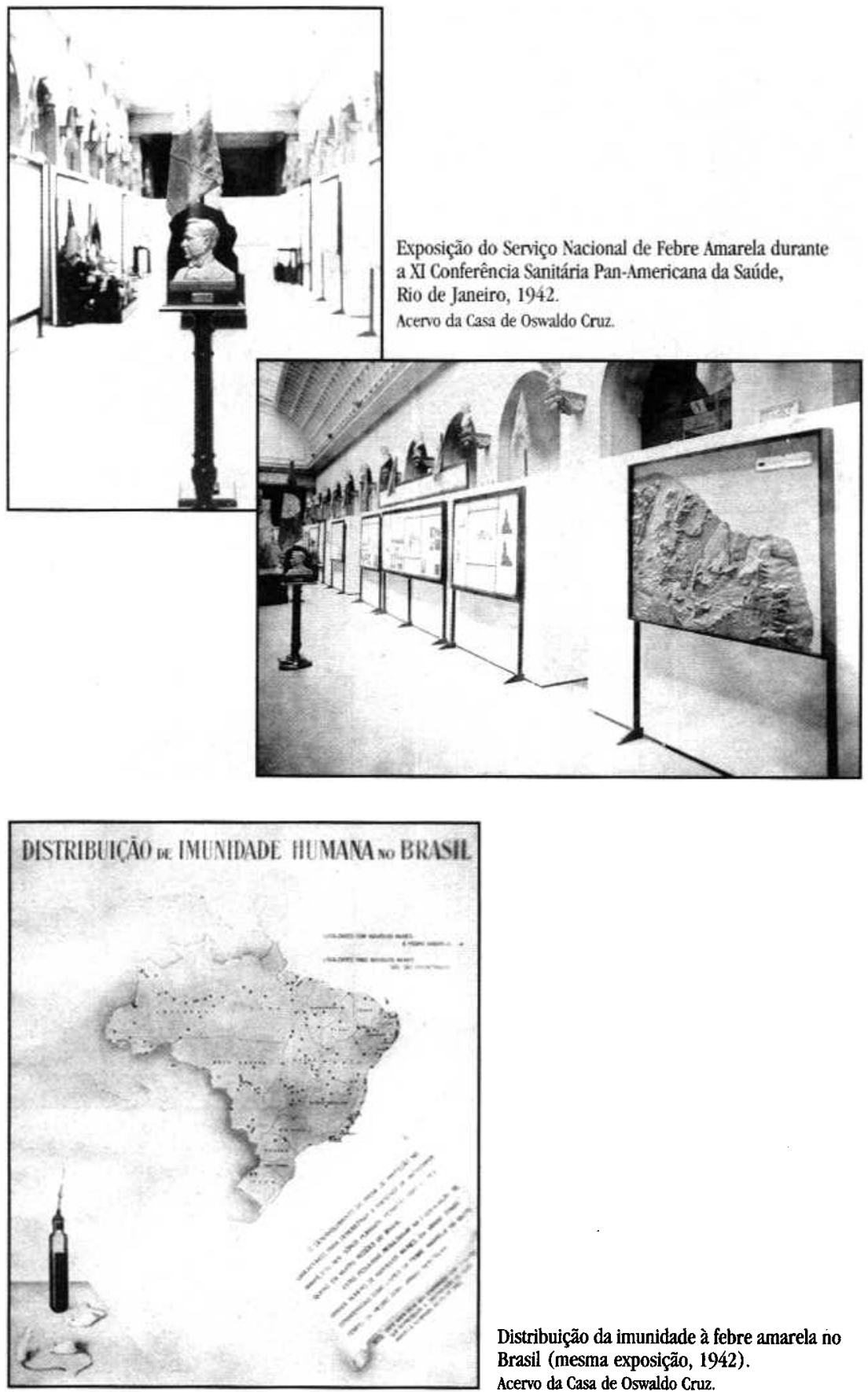

Distribuição da imunidade à febre amarela no Brasil (mesma exposição, 1942). Acervo da Casa de Oswaldo Cruz. 


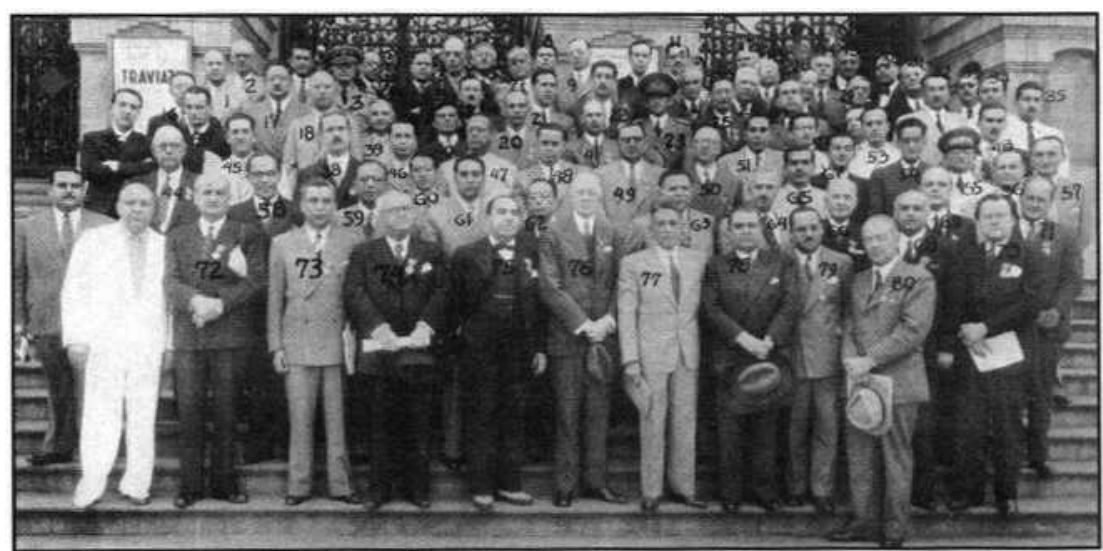

Participantes da XI Conferência Pan-Americana da Saúde em visita à Fundação Oswaldo Cruz, Rio de Janeiro, 1942. Bosp, 1942.

Seção de Vírus do Instituto Butantan, São Paulo, 1943. Acervo da Casa de Oswaldo Cruz.
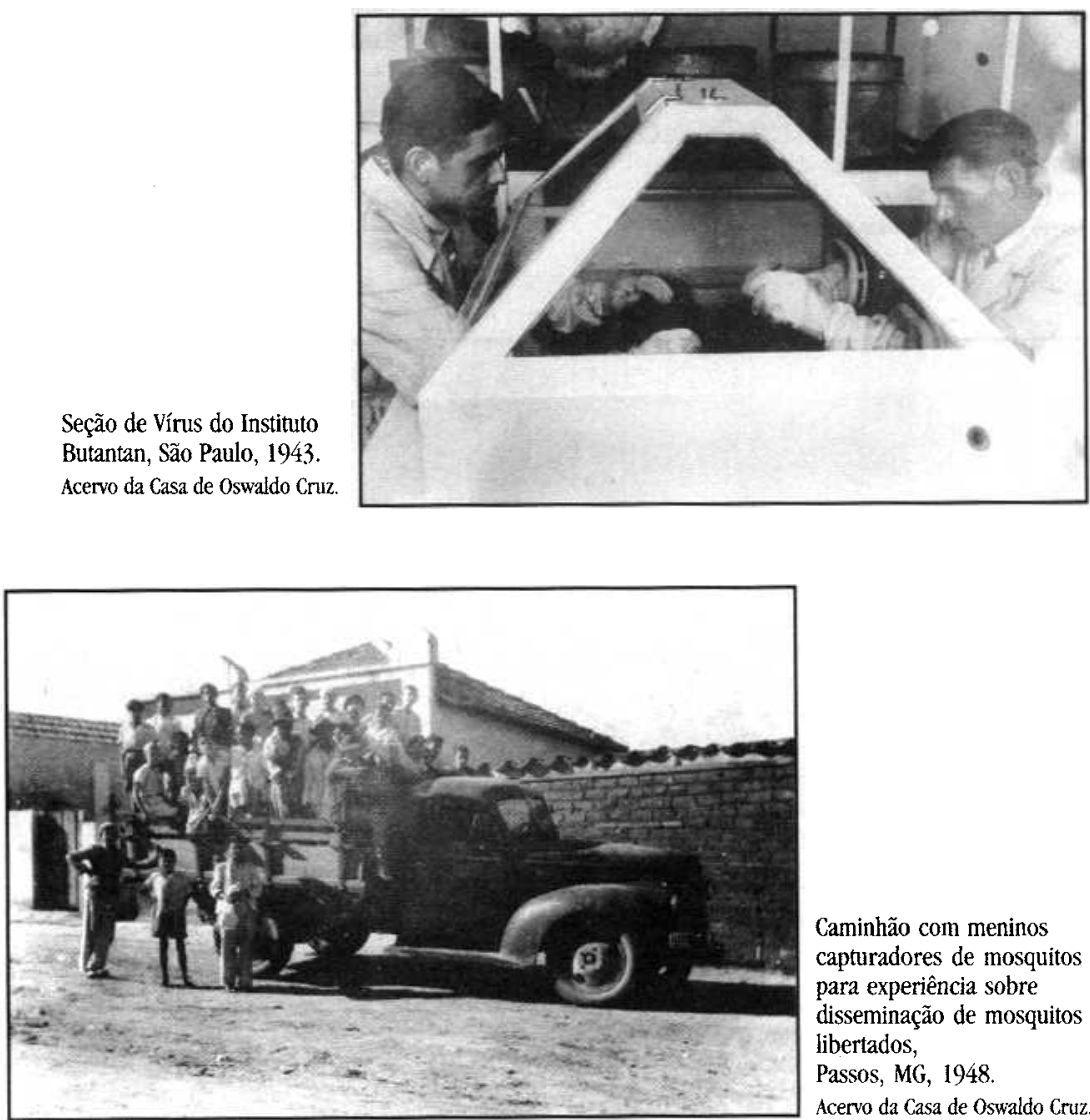

Caminhão com meninos capturadores de mosquitos para experiência sobre disseminação de mosquitos libertados,

Passos, MG, 1948

Acervo da Casa de Oswaldo Cruz. 


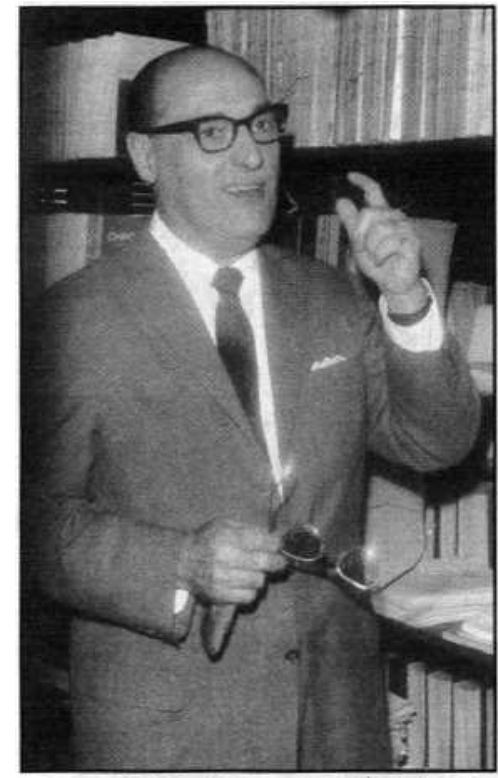

Marcolino Candau, segundo diretor geral da OMS (1953-1973).

Acervo da Casa de 0swaldo Cruz.

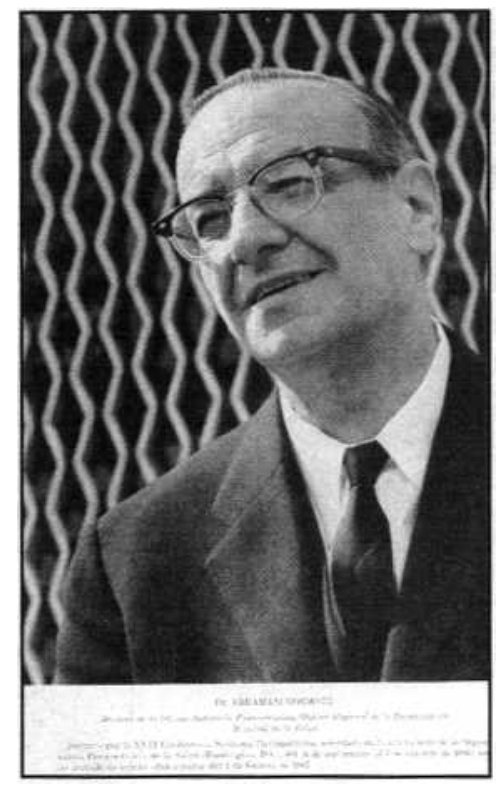

Abraham Horwitz, diretor da OPAs (1958-1975). Basp, 1966.

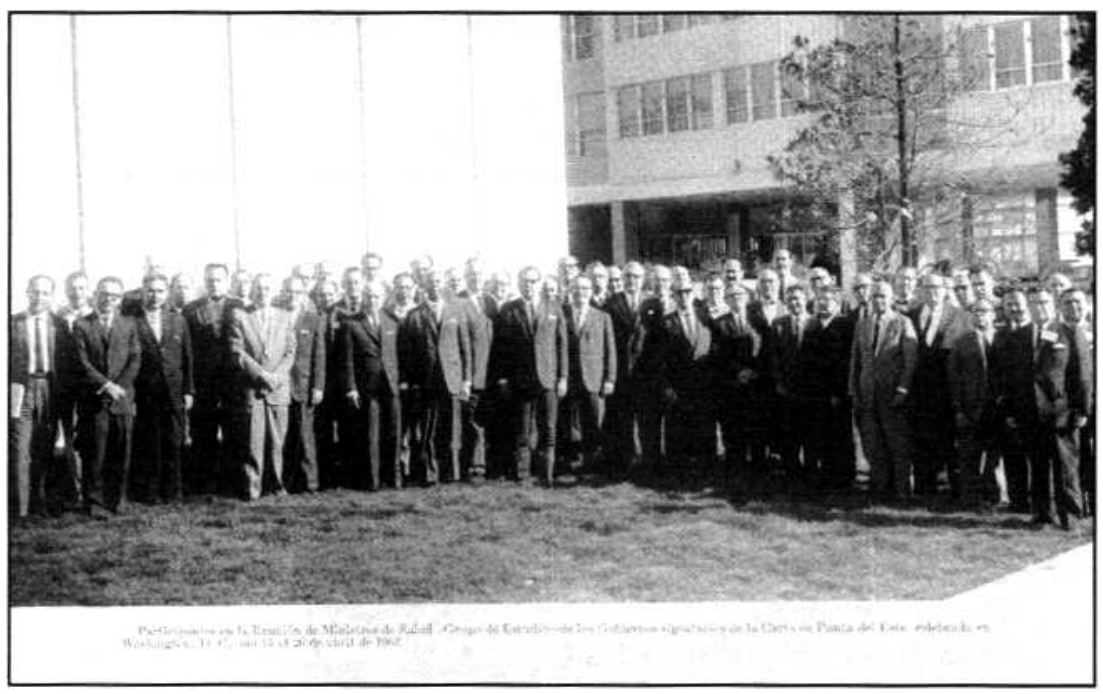

Participantes da Reunião dos Ministros da Saúde, 1963.

Bas", 1963. 


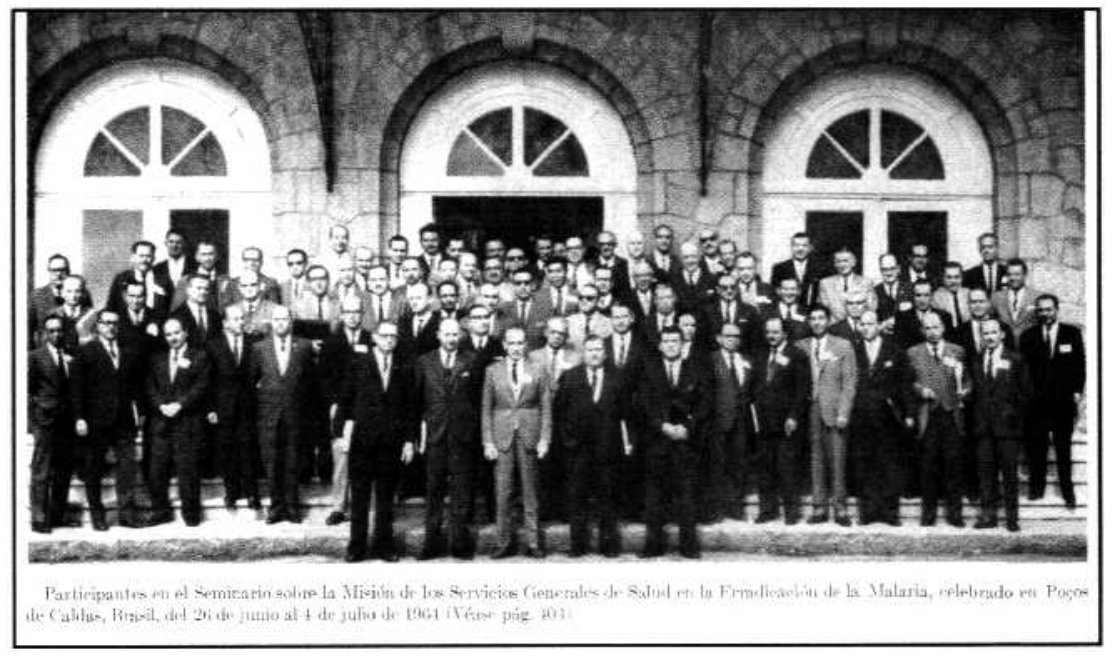

Participantes do Seminário sobre a Missão dos Serviços Gerais de Saúde na Erradicação da Malária, Brasil, 1964.

Boxp, 1964.

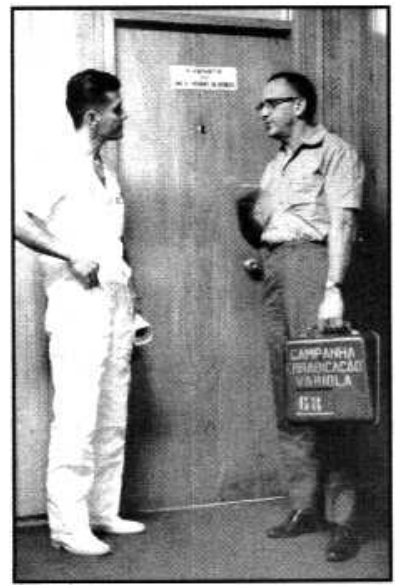

Alyrio Macedo, da Fundação SESP, durante a campanha de erradicação da variola, Brasilia, 1967.

Departamento de Arquivo e

Documentação da Casa de Oswaldo Cruz.

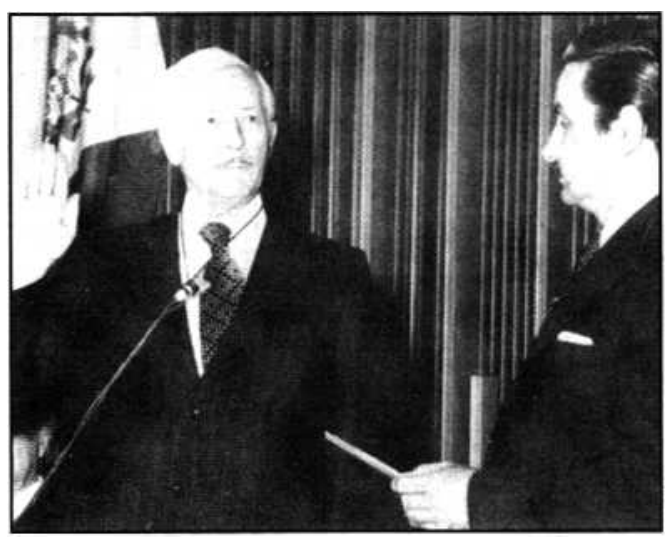

Hector Acuña, diretor da OPAS (1975-1982).

Bosp, 1975 . 


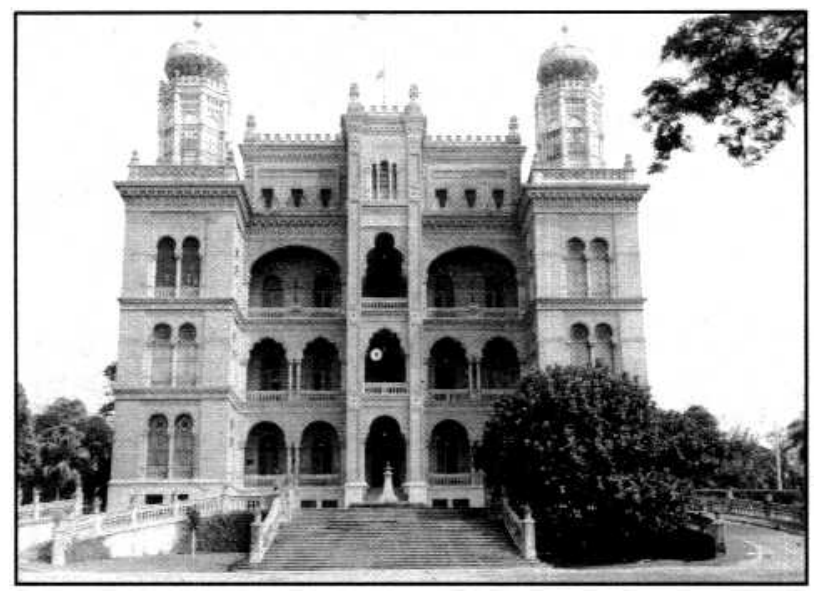

Pavilhão Mourisco da Fundação Oswaldo Cruz (Castelo de Manguinhos), Rio de Janeiro. Acervo da Casa de Oswaldo Cruz.

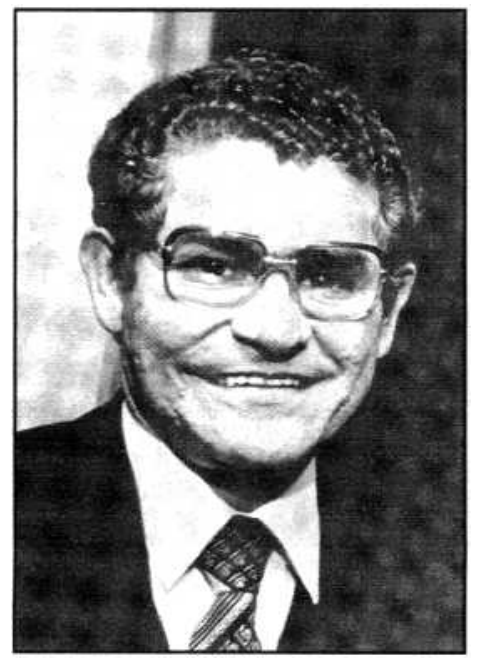

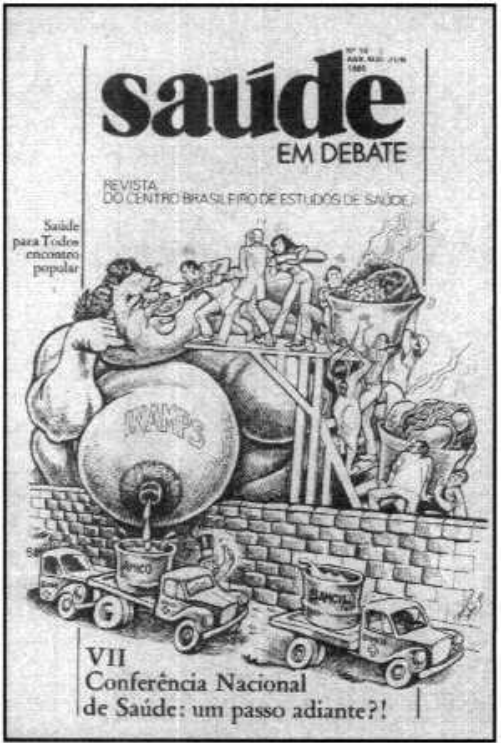

Capa da Revista do Centro Brasileiro de Estudos de Saúde (CEBEs), 1980.
Carlyle Guerra de Macedo, diretor da OPas (1983-1994). 

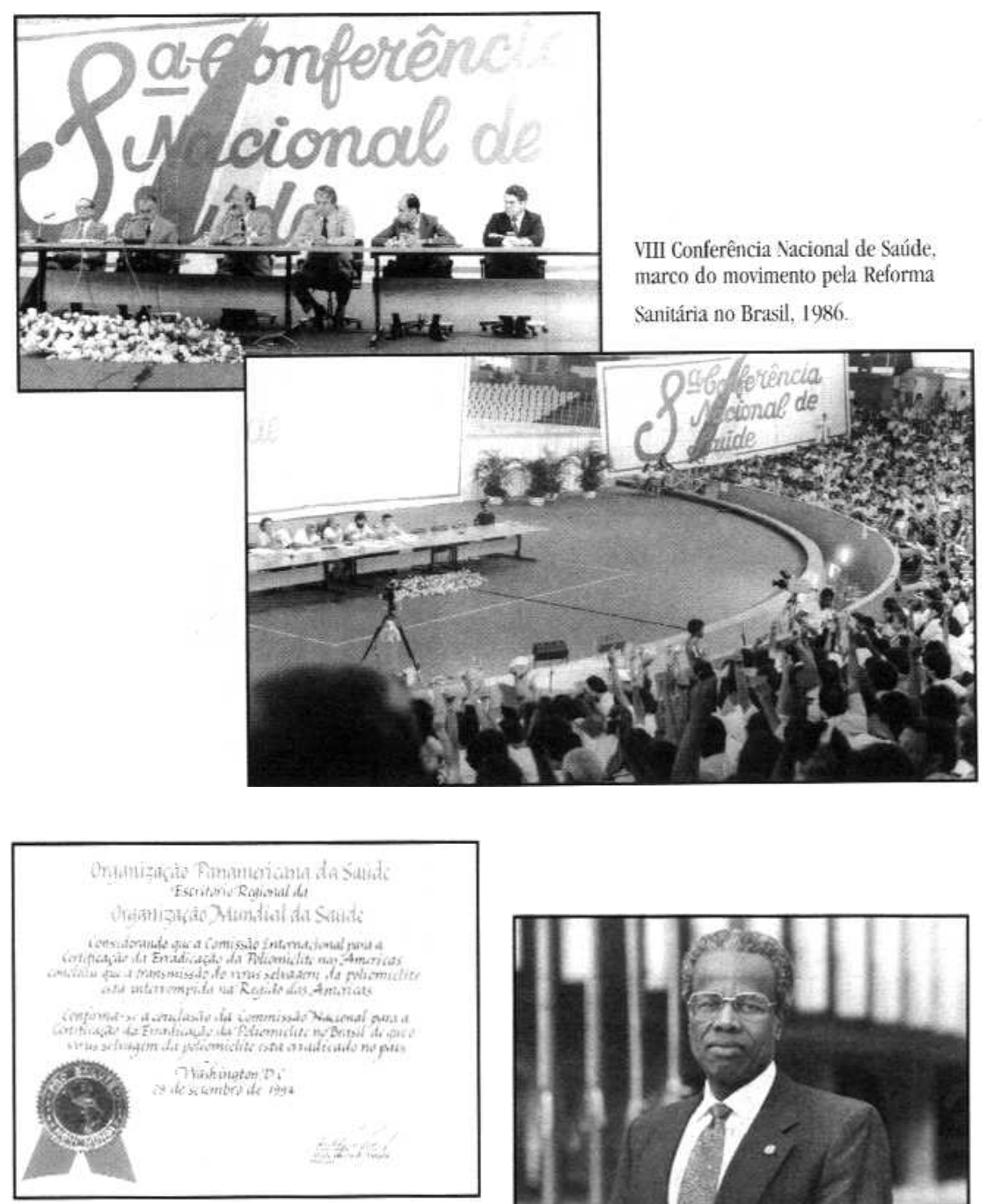

Certificado de erradicação da poliomielite nas Américas, 1994.

Acervo Casa de Oswaldo Cruz.

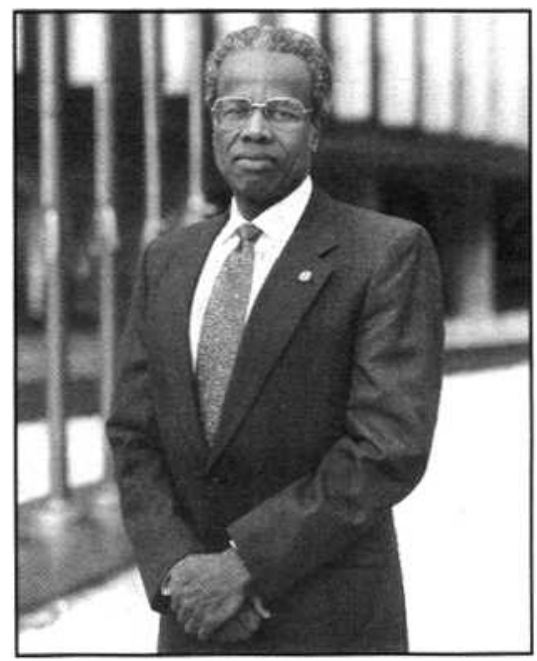

George Alleyne, diretor da Opas (1994- 2002). Acervo da OPA, Washington. 

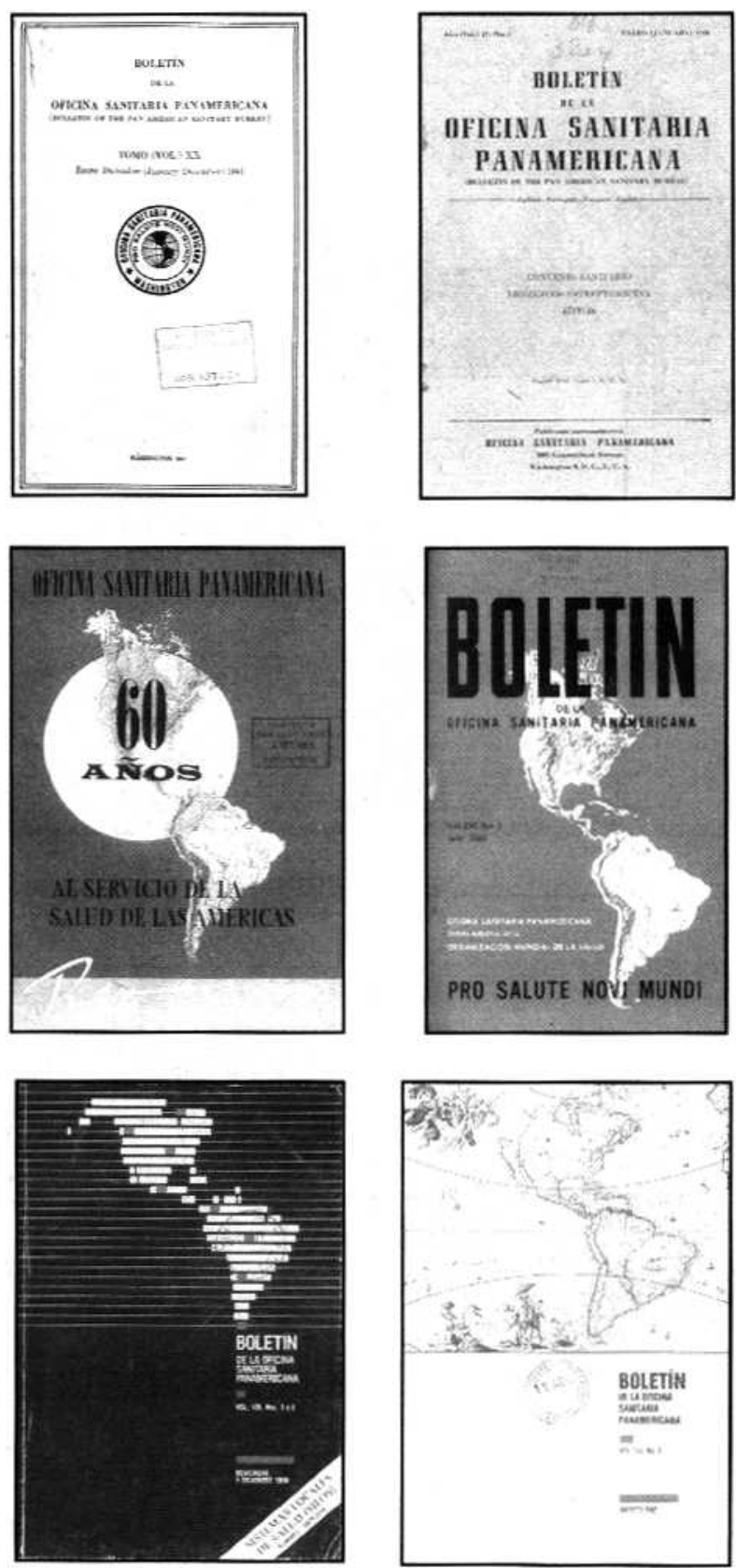

Reprodução de capas do Boletín de la Oficina Sanitaria Panamericana (Bosp), 1941-1992. 
Formato: $16 \times 23 \mathrm{~cm}$

Tipologia: Garamond

Papel: Pólen bold $70 \mathrm{~g} / \mathrm{m}^{2}$ (miolo)

Cartão supremo $250 \mathrm{~g} / \mathrm{m}^{2}$ (capa)

Fotolitos: Engenho \& Arte Editoração Gráfica Ltda (capa e miolo)

Impressão e acabamento: Millennium Print

Comunicação Visual Ltda.

Rio de Janeiro, dezembro de 2002

Não encontrando nossos títulos em livrarias,

contactar a EDITORA FIOCRUZ:

Av. Brasil, 4036 - $1^{\circ}$ andar - sala 112

Manguinhos

21040-361 - Rio de Janeiro - RJ.

Tel.: (21) 3882-9039 e 3882-9041

Telefax: (21) 3882-9006

http://www.fiocruz.br/editora

E-mail: editora@fiocruz.br 
no Brasil, são elegantes e expressam a impressionante qualidade dos dirigentes desta prestigiosa organização das Nações Unidas.

Os leitores vão desfrutar profundamente deste livro. Além de fonte de consultas de inequívoco valor, Caminbos da Saúde Pública no Brasil nos conduz a uma reflexão instigante sobre a saúde no transcorrer do último século no nosso país.

A Fiocruz está muito honrada em poder ser parceira na publicação desta obra, pois ela representa uma homenagem aos milhares de sanitaristas que construíram nosso sistema de saúde, bem como a outros tantos que, ao longo do século $\mathrm{XX}$, entregaram-se com paixão ao mister de assegurar ao continente um ambiente de viva e produtiva cooperação.

Paulo Marcbiori Buss Presidente da Fundação Oswaldo Cruz 


\section{Organização Pan-Americana da Saúde}

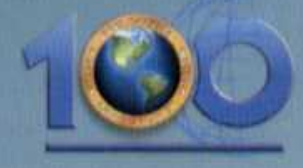

Caminbos da Saúde Pública no Brasil vem à luz como

parte das comemorações do centenário da Organização PanAmericana da Saúde (Opss) no Brasil. Propỗe-se a desenhar um quadro evolutivo, ao longo do século $\mathrm{XX}$, das políticas, dos programas e dos serviços estabelecidos para a melhoria da saúde dos brasileiros. Diversas e destacadas personalidades da saúde pública nacional contribuem para uma revisão do longo trajeto percorrido pelas politicas de saúde, desde um momento inicial, em que praticamente se restringiam a ações de controle das epidemias de febre amarela, variola e outras, concentradas nos grandes centros urbanos das regiões mais desenvolvidas do país, atéo momento atual, em que a prioridade se manifesta na consolidaçâo da saúde como um direito de todos os cidadãos e um dever do Estado.

0 livro põe em evidência o quanto o país avançou nestes cem anos em matéria de condições de saúde da população e de direito à saúde, passando por diferentes estágios de desenvolvimento econômico e social, mas chama a atenção igualmente para a persistência de problemas estruturais que determinam profundas desigualdades entre suas cinco grandes regiões geográficas e entre seus diferentes grupos populacionais.

José Noronba

Presidente da Associação Brasileira de Pós-Graduação em Saúde Coletiva (ABrusco)

ISBN 85-7541-017-2

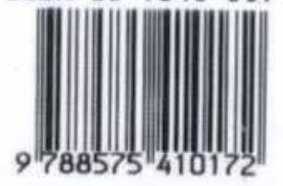

